UNIVERSIDADE DE SÃO PAULO

FACULDADE DE FILOSOFIA, LETRAS E CIÊNCIAS HUMANAS

DEPARTAMENTO DE FILOSOFIA

PROGRAMA DE PÓS-GRADUAÇÃO EM FILOSOFIA

\title{
ENTRE BERGSON E ESPINOSA: ETERNIDADE OU DURAÇÃO?
}

MARINÊ DE SOUZA PEREIRA

(Versão corrigida)

SÃO PAULO

2011 


\author{
UNIVERSIDADE DE SÃO PAULO \\ FACULDADE DE FILOSOFIA, LETRAS E CIÊNCIAS HUMANAS \\ DEPARTAMENTO DE FILOSOFIA \\ PROGRAMA DE PÓS-GRADUAÇÃO EM FILOSOFIA
}

\title{
ENTRE BERGSON E ESPINOSA: ETERNIDADE OU DURAÇÃO?
}

\author{
MARINÊ DE SOUZA PEREIRA
}

(Versão corrigida)

Tese apresentada ao programa de Pós-Graduação em Filosofia da Faculdade de Filosofia, Letras e Ciências Humanas da Universidade de São Paulo para obtenção do título de Doutor em filosofia, sob orientação da $\operatorname{Prof}^{\mathrm{a}} \operatorname{Dr}^{\mathrm{a}}$ Marilena Chaui.

SÃO PAULO

2011 


\section{Agradecimentos}

À Marilena, pela abertura para descobertas, mudanças, crescimento e tantas outras coisas que somente uma orientação generosa e comprometida pode possibilitar, porque é espaço para muitos encontros, para além dos alcances restritos que a academia, boa parte das vezes, enseja.

Aos professores que estiveram presentes de algum modo ao longo desse percurso: Franklin Leopoldo e Silva (presente desde a minha qualificação de mestrado, contribuindo muito, muitíssimo, para a minha formação); Luís César Oliva (pela amizade e confiança em nosso trabalho); Vittorio Morfino (pelo curso proferido no Departamento de Filosofia, do qual fui aluna, e pela postura ou prática filosófica que foge ao alcance de toda "vã filosofia”); Paulo Vieira Neto e Débora Morato Pinto (por aceitarem participar da banca, compreendendo as adversidades dos momentos finais).

Aos meus pais, irmãos e irmã: esteio, abrigo e afago. Não há palavras capazes de expressar a minha gratidão e amor.

À Éricka, distante fisicamente durante o processo de escrita de tese, e muito presente pelo carinho e manifestação sempre constante de confiança e dedicação - o famoso "pode contar comigo!”, sinceramente expresso e sempre tão profundamente sentido.

À Mariana, pelas longas conversas e desabafos... e por fazer da Argentina um país em que daria gosto viver!

À Vânia, por todos os belos momentos compartilhados durante a breve e inesquecível convivência, e por fazer da casa um lugar harmônico e tranquilo, com todo o sossego que se necessita em um final de tese.

À Fabiana, pela amizade fraterna, porque fruto de tantos anos de convivência, sob o mesmo teto ou não, e por sua imensa cumplicidade em todos os momentos da tese - e em tantos outros.

À Karícia, por compartir as preocupações com prazos e possíveis prorrogações, que nos fariam menos preocupadas, solitárias e mais afeitas às (no melhor sentido do termo) mundanas (e necessárias!) inspirações.

À Sandra, por me receber na França (há tantos anos atrás), pelos textos fotocopiados na BNF, escaneados e enviados, e por tantos outros gestos que somente uma verdadeira mineira (o que é um "estado de alma” e, em seu caso, é também um “estado de nascimento”), simples e generosa, pode tão espontaneamente realizar. E, ao Ludo "da viola”, o francês mais mineiro que já conheci, também pela hospedagem e pelos textos escaneados em seu trabalho (uma tese necessita de muitas mãos amigas...).

À Luíza, pelo apoio nas longas jornadas na biblioteca, acompanhadas de tantos cafés renovadores (momentos de conversas e trocas de inquietações), pelo dicionário que facilitou a minha vida e a escrita da tese, pelos pães-de-queijo e outras guloseimas afagantes (outra mineira de alma e nascença!).

Ao Cadu, companheiro antigo de muitos risos, cravados em piadas provocadas por tantas alegrias ou mazelas, como as mais duras "provas” da vida acadêmica tal qual o término de uma tese e sua defesa (pelo dom de transformar em risos o que nos faz sofrer, relativizando a sua proporção e dando outra dimensão ao seu alcance).

Ao Emílio, pelas "agulhadas" nos momentos mais difíceis, aliviando a tensão e dando ânimo para seguir em frente.

A todos os companheiros do Colégio Ítaca (Pâmella, Maurício, Roberto...) e, em especial, a Mercedes, Zezé e Sônia Drucker, que carinhosamente entenderam o momento de minha despedida, colaborando valiosamente para a finalização da tese.

À Ciça, pelas longas conversas permeadas por todos os nossos conflitos de doutorandas e professoras.

À Mercedes, pelo muito que me ensinou (talvez sem o saber) sobre o magistério e pela 
amizade que dele - e de tantos outros temas - surgiu.

À Mariê, pelas tantas atuações em momentos decisivos, e pelo incontestável carinho.

A todas as "meninas" do departamento, pela presteza e simpatia: Verônica (especialmente pelos momentos de conversa sobre filmes e muito mais), Maria Helena (especialmente pela prontidão e doçura nas informações e demandas várias...), Geni (especialmente pela atuação também em momentos específicos e muito delicados...), Luciana (especialmente também pela doçura e simpatia no atendimento e disponibilidade para a resolução de qualquer questão), Roseli e Marina.

A todos os que estiveram presentes de modo mais ou menos intenso (devido, sobretudo, à minha "ausência” durante a escrita da tese) nesse momento singular, e que são presenças certas e inquestionáveis em todo e qualquer momento da vida: Bettina, Cleide, Gláucia, Juliana, Cléo, Tatiana, Léo, Daniel, Cleudemar, Toni, Antônia, Roberta, Dedé, Britta, Ezequiel, Sole, Micaela, Vitor, Nelson e Vanessa. Muito, muito obrigada!

Ao Cnpq, pela bolsa concedida, e pela dedicação integral que ela possibilitou no último ano do prazo concebido pela universidade para a realização de uma tese. 


\section{Resumo}

PEREIRA, M. S. Entre Bergson e Espinosa: eternidade ou duração? 2011. 225f. Tese (doutorado) - Faculdade de Filosofia, Letras e Ciências Humanas. Departamento de Filosofia, Universidade de São Paulo, 2011.

Ao afirmar que a sua filosofia "vê na duração o próprio tecido de que a realidade é feita", no último capítulo de A evolução criadora, Bergson explicita o seu projeto de construção de uma nova metafísica. Sabemos que a originalidade de sua empreitada está fundamentalmente nessa exigência da apreensão do tempo, sua transitoriedade e fluidez, como aquilo de que a realidade é feita. Trata-se de declarar a realidade temporal como definição da própria existência do mundo e da experiência humana - sem a duração, não se pode falar em causalidade efetiva ou livre escolha. Sendo assim, a exigência de uma metafísica da duração se colocaria de imediato em contraposição não a uma filosofia somente, mas à história da filosófica como um todo, cuja crítica é essencial para a construção e consolidação do pensamento bergsoniano. Contudo, pensamos que, na tradição filosófica, destaca-se um autor com quem Bergson dialogou intensamente, declaradamente ou não, e que pouco esteve presente nos trabalhos dos estudiosos do seu pensamento: Espinosa. Pretendemos reconstituir esse diálogo a partir de um campo de comunicação que possibilite revelar seus pontos de entrecruzamento, confrontação e encontro. Talvez assim, o desencontro maior - entre uma filosofia da duração e, outra, ‘da eternidade’mostre-se, ao fim e ao cabo, apenas aparente.

Palavras-chave: eternidade, duração, liberdade, metafísica, história. 


\section{Résumé}

PEREIRA, M. S. Entre Bergson et Espinosa: l'éternité ou la durée? 2011. 225f. Thèse (doctorat) Faculdade de Filosofia, Letras e Ciências Humanas. Departamento de Filosofia, Universidade de São Paulo, 2011.

Dans le dernier chapitre de L'évolution créatrice, Henri Bergson affirme que sa philosophie "voit dans la durée l'étoffe même de la réalité" et rend, ainsi, explicite son projet de construction d'une nouvelle métaphysique. Nous savons que l'originalité de sa démarche se trouve essentiellement dans l'exigence de l'appréhension du temps, son caractère transitoire et sa fluidité, ce dont la réalité est faite. Il s’agit de reconnaître la réalité temporelle en tant que définition de l'existence même du monde et de l'expérience humaine - car sans la durée, on ne peut parler de causalité effective ou de libre choix. Par conséquent, l'exigence d’une métaphysique de la durée se placerait immédiatement à l'opposé non seulement d’une forme de philosophie, mais surtout de l’Histoire de la philosophie dans sa totalité, dont la critique est essentielle pour la construction et la consolidation de la pensée bergsonienne. Néanmoins, nous constatons qu'il existe, dans la tradition philosophique, un auteur avec lequel Henri Bergson a intensément dialogué, ouvertement ou pas, mais qui a très peu suscité l’intérêt chez ses spécialistes. Cet auteur est Spinoza. Nous avons voulu, par là, reconstituer ce dialogue depuis un champ de communication capable de dévoiler leurs points de croisement, de confrontation et de rencontre. Sans doute la plus grande divergence ne sera, ainsi, et après tout, qu’apparente - à savoir entre une philosophie de la durée et celle “de l'éternité”.

Mots-clés: éternité, durée, liberté, métaphysique, histoire 


\begin{abstract}
PEREIRA, M. S. Between Bergson and Espinosa: eternity or duration? 2011. 225f. Thesis (doctoral) - Faculdade de Filosofia, Letras e Ciências Humanas. Departamento de Filosofia, Universidade de São Paulo, 2011.
\end{abstract}

By stating that his philosophy "sees in duration the own tissue that reality is made" in the last chapter of Creative Evolution, Bergson explains his project to build a new metaphysics. We know that the originality of his work is based in this exigency of the sense time, its transience and fluidity, as that from which reality is made. It is time to declare the temporal reality as definition of the own existence of the world and human experience - without the duration one can not speak in effective causality or free choice. Thus, the requirement of a metaphysics of duration is put immediately in opposition not only to one philosophy, but the history of philosophy as a whole, whose criticism is essential to building and consolidating of the Bergson's thought. However, we believe that, in the philosophical tradition, there is an author with whom Bergson spoke intensely, openly or not, and that little was present in the work of scholars of his thought: Espinosa. We intend to reconstruct this dialogue from a communication space that allows to reveal their points of intersection, confrontation and meeting. Perhaps then the biggest mismatch - between a philosophy of duration, and another, 'of eternity’-shows, after all, only apparent.

Keywords: eternity, duration, freedom, metaphysics, history. 


\section{Sumário}

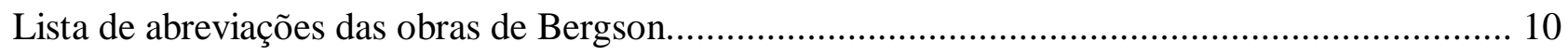

Lista de abreviações das obras de Espinosa............................................................................ 11

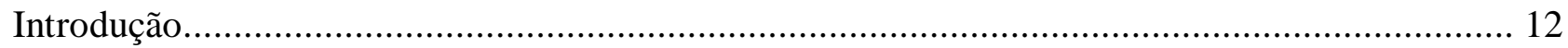

Capítulo 1 - A “evolução” da crítica ao paralelismo: apreciação histórica, empírica e lógica.......... 17

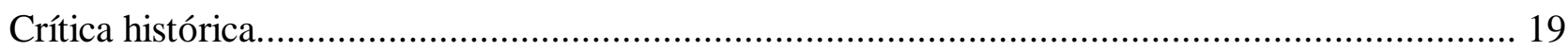

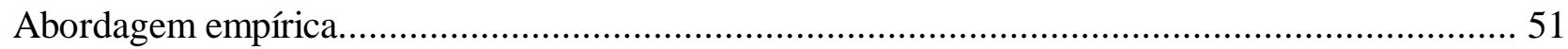

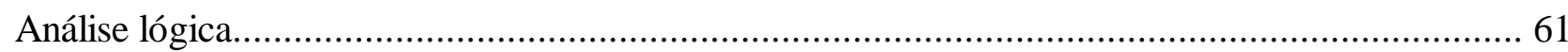

Capítulo 2 - Contra o "nada” e o espinosismo: a plenitude afetiva do conhecimento sub specie

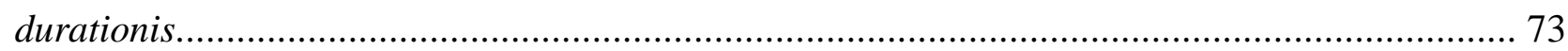

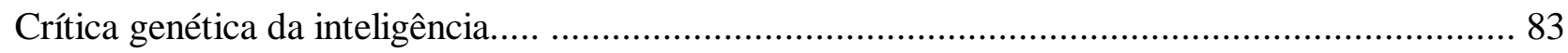

A necessidade lógica do pensamento matemático e a substância espnosista................................ 93

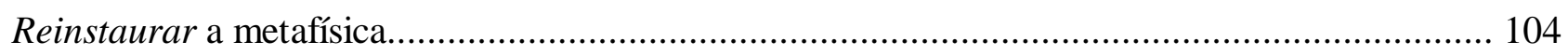

A crítica da idéia do Nada contra a concepção espinosista do Ser............................................. 115

Capítulo 3 - Espinosa: unidade e eternidade..................................................................... 128

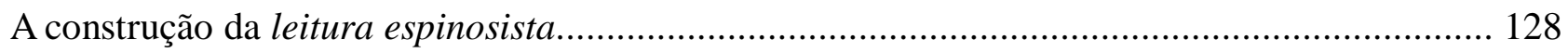

A proposição E II,P7 e unidade espinosana............................................................................... 143

Liberdade e plenitude afetiva no conhecimento sub specie aeternitatis..................................... 159

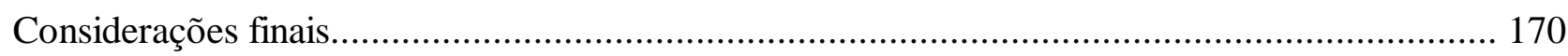

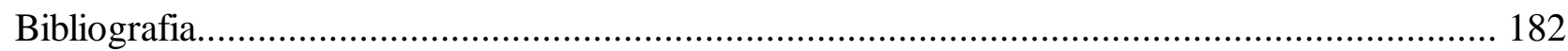

Apêndice: Contra e pelo paralelismo: Deleuze, leitor bergsoniano de Espinosa?......................... 189 
Ausência

Por muito tempo achei que ausência era falta.

E lastimava, ignorante, a falta.

Hoje não a lastimo.

Não há falta na ausência.

A ausência é um estar em mim.

E sinto-a, branca, tão pegada, aconchegada [nos meus braços,

que rio e danço e invento exclamações alegres, porque a ausência, essa ausência assimilada,

ninguém a rouba mais de mim.

(Carlos Drummond de Andrade) 


\section{Lista de abreviações das obras de Bergson}

E.: Essai sur les Donnés Immédiates de la Conscience. 144 edição. Paris: PUF, 1970.

M.M.: Matière et Mémoire. Reimpressão da 8ª edição. Paris: PUF, 2008 .

E.C.: L'évolution Créatrice. Reimpressão da 11 a edição. Paris: PUF, 2008.

P.M.: La Pensée et le Mouvant. Reimpressão da 15ª edição. Paris: PUF, 2006.

E.S.: L’Energie Spirituelle. 52 a edição. Paris: PUF, 1949.

D.S.M.R.: Les Deux Sources de la Morale et de la Religion. 164a edição. Paris: PUF, 1967.

R.: Le Rire. $87^{\mathrm{a}}$ edição. Paris: PUF, 1950.

D.S.: Durée et simultanéité. $2^{\mathrm{a}}$ edição. Paris: QUADRIGE/PUF, 1998.

E.P.: Ecrits et paroles (organizado por Mossé-Bastide). Paris: PUF, 1957.

M.: Mélanges. Paris: PUF, (ano)

Cours I: Cours I. Leçons de psychologie et de métaphysique: Clermont-Ferrand, 1887-1888.

Paris: PUF, 1990.

Cours II: Cours II. Leçons d'esthétique. Leçons de morale, psychologie et métaphysique. Paris: PUF, 1992.

Cours III: Cours III. Leçons d'histoires de la philosophie moderne. Théories de l'âme. Paris: PUF, 1995.

Cours IV: Cours IV sur la philosophie grecque. Paris: PUF, 1995.

Os cursos de Bergson contidos nos Annales Bergsoniennes também serão citados de modo a enviar para o volume em que se encontram (ex.: Annales II). 


\section{Lista de abreviações das obras de Espinosa}

Serão diretamente citadas no texto, as seguintes obras:

E.: Ética. Os dois primeiros livros são citados a partir da tradução do Grupo de Estudos Espinosanos da Universidade de São Paulo. Os outros livros são citados a partir da tradução de Tomaz Tadeu (Belo Horizonte: Autêntica Editora, 2008). As abreviações serão feitas de acordo com a seguinte ordem: o livro da Ética, o número da proposição e, se for o caso, seus complementos (demonstrações, corolários e escólios), conforme o uso convencionado. Ex.: E II, P7esc.

T.R.I.: Tratado da Reforma da Inteligência. Tradução de Lívio Teixeira. São Paulo: Martins Fontes, 2004.

T.T.-P.: Tratado Teológico-Político. Tradução de Diogo Pires Aurélio. São Paulo: Martins Fontes, 2003. 


\section{Introdução}

Um estudo sobre Bergson e Espinosa suscita, em geral, surpresa. Isto por distintos motivos. Da parte dos que conhecem a obra bergsoniana, por exemplo, há uma visão de ambos como avessos um do outro, ou melhor, como pensadores cujas filosofias vão em direções completamente opostas, tal como se apreende pela crítica de Bergson à filosofia espinosista. A partir dela, qualquer tentativa de aproximação ou diálogo entre esses filósofos pareceria insustentável, e passível de correção, pelo uso da própria crítica e suas interdições. Todavia, ao nos depararmos com essa leitura crítica e seus desdobramentos, vimos nela menos o sinal de uma cisão irrecuperável do que a fonte de muitas questões fecundas, tanto no que concerne ao pensamento de ambos, quanto ao que a própria crítica poderia revelar sobre sua origem e importância. Caberia primeiramente, portanto, penetrar nela, acompanhá-la nos diferentes momentos do pensamento bergsoniano para, assim, compreender a sua motivação e, quem sabe, dialogar com ela, o que significaria também interrogar, de algum modo, a leitura que a sustenta.

A primeira referência a Espinosa, na obra de Bergson publicada, diz respeito à questão do paralelismo como resolução do problema metafísico da relação entre corpo e alma. É, pois, a crítica ao paralelismo que, primeiramente, guia o nosso trabalho. Ao tentar "mapeá-la” nos diferentes textos e contextos, vemo-la ampliar-se e se transformar no verdadeiro adversário do bergsonismo no que diz respeito aos problemas oriundos da projeção do físico para o mental, tal como aparecia na ciência de sua época. As implicações dessa problemática levam-nos ao centro das preocupações de Bergson e ao desdobramento contínuo dessa filosofia que "vê na duração o tecido de que é feita a realidade”. É tentando apreendê-la que somos novamente conduzidos pela crítica (que, dessa vez, se volta para a idéia do Nada) à presença de Espinosa como um dos adversários privilegiados do bergsonismo. Na perspectiva de nosso trabalho, a crítica é tanto algo que perpassa o texto quanto o que revela a própria filosofia da duração. Isto porque a crítica em Bergson é fundamental, constituindo a dinâmica do seu pensamento “às voltas com a realidade”, o que significa também, ou sobretudo, com a necessidade de revelar o que se dissimula o mais das vezes sob uma suposta realidade ou assume ares de verdade - criticar o nada, por exemplo, é mostrar o que se esconde por trás de sua idéia explicativa, é retirar a sua força e demonstrar a sua gênese. Vemos, assim, essa filosofia como o exercício ou a prática de um pensamento que se constitui pela compreensão da gênese do próprio processo de explicação e entendimento humano e que, ao fazê-lo, é capaz de 
alcançar uma condição sobre-humana, não porque parta ou encontre um princípio explicativo fora da existência humana propriamente dita, mas porque o faz como violência às práticas habituais e naturais de explicação. Logo, um pensamento que desnaturaliza as explicações, o que é dado, o que é primeiro e imediato - porque assim o percebemos e não porque assim realmente o seja. Trata-se de um esforço direcionado no sentido de desvelar o superficial e alcançar o que há de mais profundo no homem e tudo o que lhe diga respeito, e nada há que não lhe diga respeito. Profundo aqui não por ser distante, mas por ser aquilo que nos constitui e que, por ser o mais próximo, é também o mais difícil de ser apreendido. E, para realizar tal tarefa, a verdadeira tarefa de toda filosofia, faz da intuição um método de superação humana, não com o sentido que muitos deram a esse termo, o que o fez hesitar quanto ao seu uso, nas palavras do próprio Bergson, mas em um sentido próprio, assim como muitos dos termos por ele utilizados, caracterizando-se também por uma subversão crítica da herança filosófica. O método bergsoniano é o que permite separar os mistos da experiência cotidiana em direção à experiência da duração e, assim, à vivência de uma nova e distinta experiência do pensamento. Partir da distinção significa, neste caso, atingir as condições da experiência. Ou seja, não se trata, para Bergson, de partir das condições dadas a priori para toda experiência possível, mas de partir da experiência real, e encontrar suas condições enquanto tendências constitutivas do próprio processo vital e também humano. Já que distinguir é depurar o misto que toda experiência envolve - encontrar, por exemplo, o que há de realidade e ilusório no conhecimento -, isso significa que nem a verdade se encontra em um plano superior, nem a ilusão lança o homem a um plano inferior. Nem um, nem outro é mais ou menos humano, ambos o são, o que não significa uma relativização do conhecimento, mas a compreensão do que constitui a experiência propriamente humana.

Ora, nesse sentido, encontramos algo que nos fez pensar na filosofia de Espinosa. Devemos afirmar, antes de mais nada, que não se trata aqui de forçar uma aproximação. Ao longo de sua obra, Bergson teceu várias considerações sobre o autor da Ética e o fez de modo a mostrar os problemas que a sua filosofia encerra, as dificuldades, as velhas questões ou velhas mercadorias às quais ela se reduz - as teses da metafísica antiga. Mas, consideramos que, também ao longo de sua obra, há um constante diálogo com esse autor, como inspiração e, isto tanto no sentido de algo que dá a pensar, que, por sua profundidade e fecundidade, suscita outros tantos pensamentos (mesmo contrários), quanto no sentido de uma latência, o que não é um espinosismo em Bergson, e sim a presença de uma inquietação que o impulsiona, juntamente com outras, e com a qual comunga. Em certos momentos da obra bergsoniana, vemos passagens elogiosas em relação a Espinosa, e consideramos que, em tais casos, ele o faz por reconhecer "o ímpeto de intuição que faz o seu sistema [de 
Espinosa] estremecer”, para, logo em seguida, contrapor-se a ele, demarcando as suas diferenças. Porém, há um fundo, que permanece e que não pode ser ignorado, de temas, preocupações (e a primeira delas, para nós, é a questão da liberdade, fundamental nos dois autores) e reflexões. Se, de acordo com Bergson, filosofar consiste precisamente em se colocar, por um esforço de intuição "no fundo de um mesmo oceano", do qual todos os sistemas partem, ainda que "tragam à superfície matérias muito diferentes”, e “é sobre essas matérias que trabalham os discípulos, já que este é o papel da análise” (P.M., p. 225), pensamos que muito do que ficou do pensamento de Espinosa se tornou um material cristalizado por obra de pensadores adversários a ele, ou adversos às profundezas dessa filosofia, procurando neutralizar os seus abalos. Neste sentido, constituiu-se uma tradição de leitura da obra espinosana, ao longo de séculos, que influenciou gerações de leitores e, dentre eles se encontra, pensamos, o próprio Bergson. Não poderemos esmiuçar as fontes da leitura bergsoniana, mas reconstituiremos a leitura tradicional e veremos o quanto há de parentesco entre elas.

Sabemos que, para Bergson, é fundamental desfazer certos equívocos do pensamento ocidental, os quais geraram falsos problemas, porque coisas que diferem por natureza foram tomadas por gradações ou intensidades, por mais ou menos, quer dizer, foram vistas como se entre elas houvesse simples diferenças de grau. Nesse sentido, há, em sua filosofia, um esforço de dar ao tempo a importância que lhe fora negada ao longo de toda a tradição filosófica. O tempo, a transição e o movimento não foram vistos como o que realmente são: passagem, fluidez, continuidade e heterogeneidade. De um lado, isto ocorreu porque não foram tomados em si mesmos, mas a partir do que não são: instantes e pontos fixos. De outro, para escapar das dificuldades que geravam, foram tomados como simulacros da verdadeira realidade - imóvel, permanente e eterna. Tal se fez por dificuldades do próprio ponto de partida: utilizar os procedimentos da inteligência, deslocandoos da prática para a contemplação, e, concomitantemente, tentar superar a própria inteligência, que operava no tempo, subtraindo-se a ela e, desse modo, ao próprio tempo. Não se percebeu que o tempo já havia sido negligenciado, porque isto é próprio da inteligência e que, portanto, procurar algo fora do tempo e do movimento, na eternidade e na imutabilidade, corresponde aos procedimentos da própria inteligência, ou seja, tal se faz dentro do seu alcance, e não fora dele. Colocando a duração seriamente ou partindo dela, pela experiência, todos os pseudo-problemas relativos à liberdade desaparecerão. A experiência da duração é o que permite uma experiência integral, a qual não é nada menos que a própria experiência da liberdade. Se duração e liberdade não se separam, claro está que uma filosofia que se pauta pela eternidade e necessidade seria completamente oposta à filosofia da duração. 
A crítica bergsoniana, quanto à impossibilidade da liberdade na filosofia de Espinosa, se insere num quadro de polêmicas sobre o denominado "problema do espinosismo", que seria justamente a incompatibilidade entre a liberdade e uma filosofia da necessidade absoluta. Caberá, para tanto, retomar a idéia subjacente à leitura crítica bergsoniana e perguntar se tal crítica não foi orientada por uma leitura herdada da tradição interpretativa da filosofia espinosana. Situada a crítica bergsoniana, pela leitura que provavelmente a ensejou, buscaremos outras leituras (recentes) da obra espinosana e, com elas, veremos novas possibilidades de comunhão de idéias entre os dois filósofos. Mas, caberá perguntar também o quanto a leitura do espinosismo foi importante para a filosofia bergsoniana, independentemente do fato de ter sido "correta” ou "incorreta”. Assim, no último capítulo desta tese, abordaremos a filosofia de Espinosa em contraposição ao espinosismo, ou seja, à leitura que subjaz à crítica bergsoniana. Não se trata de esmiuçar essa leitura, buscando seus antecedentes históricos - o que apenas apontaremos com a ajuda de comentadores que se dedicaram à compreensão dessa tradição interpretativa -, mas de ler o texto de Espinosa sob outra perspectiva. Desse modo, discutiremos o significado do método geométrico e questionaremos o "paralelismo" em sua doutrina. Este último tema também estará presente no apêndice inserido nesta tese, o qual se volta aos seus desdobramentos nos trabalhos de alguns estudiosos da filosofia espinosana, tal como Deleuze, que dissera, para a surpresa de muitos, que esse termo caberia mais à filosofia de Espinosa do que à de Leibniz, por quem ele fora efetivamente afirmado.

Para Espinosa, dizer que algo é matematicamente demonstrado significa afirmar um conhecimento causal demonstrado a priori ou um saber no qual o conhecimento do efeito depende do conhecimento da causa e o envolve. O que também significa que uma idéia verdadeira ou adequada é uma idéia conhecida por sua gênese, ou da qual conhecemos as razões internas da sua produção. Ou seja, ela demonstra os preconceitos e denuncia, de certo modo, o não-saber que impede o conhecimento verdadeiro. Conhecer é compreender a nossa própria capacidade de conhecimento, o que significa não só conhecer leis e propriedades comuns às coisas, mas as próprias essências, as coisas nelas mesmas, sua singularidade e sua participação na essência divina conhecimento intuitivo. Em Espinosa, a experiência constitui as duas pontas da doutrina, dela partimos (conhecimento imaginativo, de existências singulares) e a ela chegamos (conhecimento intuitivo, de essências singulares). Ir além do dado e, mais do que ser parte de um todo, tomar parte. E, se é o conhecimento intuitivo que nos possibilita tal superação, é também a intuição que, em Bergson, coloca-nos em contato, ou mais, nos faz coincidir com o impulso criador do qual podemos também participar. Uma filosofia pautada pela intuição “dá-nos também mais força para agir e viver; pois, com ela, não nos sentimos mais isolados na humanidade, a humanidade também já não nos 
parece isolada na natureza. [...] Todos os vivos se tocam e todos cedem ao mesmo formidável impulso” (E.C., 293). Pensamos que a intuição bergsoniana e a ciência intuitiva espinosana podem se encontrar, por exemplo, na exigência filosófica de uma nova experiência do pensamento que conduza à liberdade e nos faça, portanto, mais fortes e alegres - tendo a alegria, em ambos, um novo e profundo sentido.

Trata-se, para nós, de um entrecruzamento que possibilite a (re)construção do diálogo entre ambos, a partir de um campo de comunicação que revele tanto o confronto - do qual partimos -, como também os momentos (ou movimentos) de encontro, que, mesmo não sendo explicitamente apontados por nós, poderão ser percebidos pelo leitor que tiver a paciência de ir até o fim desta leitura. 


\section{Capítulo 1 - A “evolução” da crítica ao paralelismo: apreciação histórica, empírica e lógica}

Em seu primeiro livro, Ensaio sobre os dados imediatos da consciência (1889) ${ }^{1}$, Henri Bergson apresenta a distinção que constitui o núcleo dessa obra e estará sempre, como sabemos, no centro de suas preocupações, revelando-se como motivo que, a partir de novas considerações e questões, o impelirá em suas futuras obras, qual seja, a distinção entre a duração e o espaço. Distinção primeira, posto que nuclear, e que, logo de saída, coloca os termos iniciais de uma discussão que também estará doravante presente: a relação entre a ciência e a metafísica. Não é por acaso que o problema escolhido para ser debatido no primeiro livro seja "o problema da liberdade, comum à metafísica e à psicologia”. Mas, o que nos parece interessante é que, já no prefácio do livro, Bergson nos faça atentar para o fato de que a solução desse problema não está na resposta propriamente dita, que deveria ser buscada ou encontrada, mas no próprio problema. Ele surge de uma confusão entre a duração e a extensão, a sucessão e a simultaneidade, a qualidade e a quantidade, mantida tanto pelos deterministas quanto por seus adversários, e, "uma vez dissipada essa confusão, ver-se-ão talvez dissipadas as objeções levantadas contra a liberdade, as definições que lhe damos, e, em certo sentido, o próprio problema da liberdade” (E., p. VII-VIII). Problema que será objeto do último capítulo do livro, após o exame crítico, nos dois capítulos anteriores, de temas e conceitos "mais propriamente" científicos, demonstrando que o cerne da questão, ou do livro, é algo que ultrapassa o próprio domínio da psicologia: o questionamento do tempo ou a sua reproblematização como categoria metafísica fundamental. A filosofia bergsoniana se faz nessa busca. Com ela, ciência e metafísica são constantemente colocadas em foco. Neste capítulo, interessa-nos ressaltar que não se trata, para Bergson, de questionar, no sentido de invalidar, a ciência em seu domínio, mas de repensar o que há de metafísica na ciência (como postulados ocultos), assim como se tratará de inventariar o que há de ciência na metafísica (como procedimentos transformados em regra universal). Um dos problemas que o primeiro livro aborda, e que é exemplo da confusão entre postulados científicos e teses metafísicas, refere-se ao epifenomenismo, ou seja, à assunção da consciência como um efeito sutil do que se passa no plano material, no cérebro mais especificamente. O exame crítico desta teoria científica será feito não somente nessa primeira obra. Com ele, uma nova concepção de metafísica será continuamente traçada e veementemente revigorada. Tal exame crítico é parte do método bergsoniano pelo qual os “mistos impuros” são separados e as articulações intrínsecas às coisas - “naturais” - são descobertas

\footnotetext{
${ }^{1}$ Doravante, será mencionado como Ensaio.
} 
ou reencontradas. Em princípio, uma vez que teremos oportunidade de desenvolver outra perspectiva crítica no segundo capítulo desta tese, tal exame é: histórico, porque recupera as diferentes (e redundantes) concepções erigidas pelo pensamento humano às voltas com o conhecimento e com a problemática da existência; empírico, porque retoma os dados científicos, reexaminando-os e reordenando-os em vista de uma "metafísica positiva”; e, por fim, lógico, porque a sua origem remonta a uma ilusão, “a mais sutil ilusão filosófica”, uma vez que o paralelismo é apenas um paralogismo. Aqui, procuraremos mostrar também por que Espinosa pode ser visto como um interlocutor privilegiado de Bergson no que concerne às consequências modernas das relações, ou mútuas implicações, entre ciência e metafísica.

Falar em “evolução” da crítica significa que ela assume, ao longo do pensamento de Bergson, uma importância maior do que a inicial, mas não quer dizer que se trata de uma reconstituição cronológica das obras ou cursos que serão abordados. São dimensões diferentes da crítica, capazes de nos revelar o peso de tal tese metafísica no determinismo científico, ou melhor, a mudança de perspectiva operada no tratamento bergsoniano desse tema: da refutação mais direta dos problemas do determinismo (ainda e sempre presente nas preocupações do filósofo) ao combate àquela que Bergson considera a sua "metafísica inconsciente”: a tese do paralelismo. Há uma espécie de reconhecimento da importância assumida pela tese do paralelismo, que se torna um adversário inquestionável, e isto pode ser justificado, por exemplo, pelos três artigos metafísicos que compõem a coletânea A energia espiritual (1919) - concebida de modo a reunir textos publicados separadamente e que tratam dos “resultados de alguns de [seus] trabalhos”, enquanto a segunda coletânea, O pensamento e o movente (1932), como sabemos, apresenta artigos sobre o seu “trabalho de pesquisa” ou método -, pelo prefácio da sétima edição de Matéria e memória, pelo curso sobre a "História das teorias da memória”, ao qual nos dedicaremos mais detidamente nesta parte de nosso trabalho, e por outros textos que abordaremos ou mencionaremos aqui, como o debate sobre "O paralelismo psicofísico e a metafísica positiva”.

Desde a primeira menção ao paralelismo, no Ensaio sobre os dados imediatos da consciência, à sua abordagem na penúltima coletânea de artigos, última obra em que tal problematização é retomada, há uma mudança de peso ou perspectiva em seu tratamento, e isto, se significa uma tomada de consciência quanto ao debate fundamental, não significa que muitos de seus termos já não estivessem presentes anteriormente, implícita ou declaradamente. Assim, o último artigo de A energia espiritual, "O cérebro e o pensamento”, encerra o problema ou debate sobre o paralelismo e, ao mesmo tempo, trata-se de um dos artigos mais antigos da referida coletânea, tendo 
sido primeiramente publicado em $1903^{2}$. Não procuraremos, portanto, mostrar quando exatamente a crítica ao paralelismo assume um peso maior, nem apontar um tratamento cronológico das suas dimensões (histórica, empírica ou lógica), mas demonstrar a sua importância pelo estudo de cada dimensão da crítica, a qual pode ser recuperada em diferentes trabalhos (livros ou cursos) de diferentes anos.

\section{Crítica histórica}

A abordagem histórica, tal qual Bergson realiza nos textos que se referem à origem do determinismo contemporâneo, é uma busca genealógica, uma vez que se trata de remontar às origens dessa explicação para a relação entre o corpo e a alma, mostrando a sua filiação ou buscando os seus antecedentes históricos, de modo a revelar o que ela tem de redundância no que diz respeito às soluções para os problemas criados, na história da filosofia, pelo pensamento ocidental. Trata-se de uma visão histórica das teorias do conhecimento que mostra uma herança de temas e procedimentos. Caberá a outro exame a análise da causa da continuidade dessas teorias em seus aspectos fundamentais, causa esta que se situa fora da história propriamente dita, como veremos no próximo capítulo.

Antes de abordarmos os textos nos quais o exame histórico do paralelismo é feito, reconstituindo a crítica de Bergson, faz-se necessário uma "palavrinha” sobre o Ensaio, pois nele é feita uma menção ao paralelismo de modo um tanto particular, o qual merece alguns comentários.

Em seu primeiro livro, ao apontar os problemas do determinismo físico de seu tempo, que representa movimentos moleculares no cérebro a partir dos quais surge a consciência como uma fosforescência, Bergson o contrapõe ao paralelismo dos “grandes pensadores” (E., p. 111) correspondência rigorosa entre os estados de consciência e os modos da extensão -, cuja razão não se encontra em questões de ordem física, mas metafísica: Leibniz a atribuía a uma harmonia preestabelecida e Espinosa, ao desenvolvimento, em duas línguas diferentes, da mesma eternidade verdadeira (E., p. 111). Os paralelismos de Espinosa e Leibniz são apresentados, em contraposição ao determinismo científico, como uma solução aprimorada (perfeita, rigorosa) que, contudo, não poderia se repetir na atualidade. As explicações quanto à realidade, no passado, eram sustentadas

\footnotetext{
${ }^{2}$ Devemos parte de nossa reconstrução da mudança de perspectiva de Bergson, quanto ao peso da tese do paralelismo, aos comentários e notas de Camille Riquier sobre o texto "A alma e o corpo", presentes na edição crítica de $A$ energia espiritual, feita sob a direção de Frédéric Worms. Teremos ocasião de apontar a importância da recente reedição das obras de Bergson - fundamental para o nosso trabalho e para todos os que se dedicam ao estudo desse filósofo.
} 
por teses metafísicas, o que não mais aconteceria. Bergson não nega que se possa verificar uma relação entre os estados cerebrais e os estados de consciência, e sim que estes sejam reduzidos àqueles, como efeito direto ou indireto, pois isto só é possível porque se extrapola a experiência (verificação experimental da ligação em um número restrito de casos). Assim como supõe moléculas e átomos determinados uns pelos outros, o determinista também tomará por absoluta a determinação dos fatos de consciência uns pelos outros. Desse modo, nasce o determinismo associacionista, o qual tentará se apoiar no mesmo mecanicismo físico que sustenta os fenômenos da natureza. Eles se prestarão uma ajuda mútua. O mecanicismo, ao mesmo tempo em que empresta ao determinismo associacionista seu caráter geométrico, fazendo-o mais rigoroso, torna-se universal. Mas, o determinismo psicológico também estaria por trás do determinismo físico, pois a busca por mediações capazes de fornecer o conhecimento dos estados internos se colocaria no início de todo o processo - o determinismo físico não seria outra coisa que “o determinismo psicológico tentando se verificar e fixar os seus contornos por um apelo às ciências da natureza” (E, p. 112). Um auxilia o outro, havendo uma espécie de endosmose entre eles, para usar uma metáfora bergsoniana. O Ensaio desmonta teoricamente os argumentos deterministas, mostrando seus equívocos conceituais, porém o faz em vista de uma discussão propriamente filosófica, o questionamento do problema da liberdade.

No terceiro capítulo do livro, no qual o problema da liberdade é explicitamente tratado, Bergson retoma alguns argumentos dos capítulos anteriores, que definem o determinismo físico e o determinismo psicológico, contra os quais o livro se volta, porque é no seio dessa discussão, ou mais especificamente, no seio da discussão entre os partidários do determinismo psicológico e seus adversários que a liberdade é problematizada, saindo intacta, já que uns e outros admitem, no fundo, o mesmo postulado que caberia combater. Isto faz com que o "problema da liberdade” se mantenha, enquanto a própria liberdade se ausente ou se dilua, quando deveria ser o contrário: é com a dissolução do problema que a liberdade se fará efetivamane presente. Bergson caracteriza o determinismo psicológico, "sob sua forma mais precisa e mais recente” como algo que "implica uma concepção associacionista do espírito” e se define por uma distinção nítida dos fatos psíquicos coexistentes, e por uma projeção do encadeamento dos fatos materiais para o fluxo da consciência, tomando-o por um encadeamento causal interno à própria consciência, de modo que a liberdade é suprimida por tal encadeamento causal necessário e, mesmo, previsível. Os adversários desse determinismo, ainda que sustentem a liberdade, permanecem presos à sua problemática, pois mantêm inconscientemente a tese determinista, a separação dos estados psíquicos e a noção de "grandeza intensiva”, de acordo com a qual se pretende medir os estados de consciência, e tal se deve ao 
3 A questão fundamental do primeiro capítulo do Ensaio sobre os dados imediatos da consciência refere-se à atribuição de uma grandeza à intensidade. Primeiramente, Bergson apresenta as formas mais "puras” de intensidade, as que se exprimem em estados não representativos ou que "parecem bastar a si mesmas”, ou seja, não parecem depender de nenhuma exterioridade: as alegrias e tristezas profundas, as paixões refletidas, as emoções estéticas e morais. Num segundo momento, ele aborda os fenômenos mistos ou "intermediários”, analisando os casos do esforço e da atenção. Por último, a respeito das diferentes intensidades, o filósofo trata das sensações. Ligando-se à exterioridade, a sensação acaba por ter um valor representativo que a expõe à ilusão das variações quantitativas. A respeito desse último aspecto, ele se volta, em princípio, para as sensações afetivas (prazer e dor) e, depois, para as sensações representativas (sabor, odor, temperatura, som, luz). Bergson mostra que nossa tendência à quantificação dos estados psíquicos se enraíza em um hábito da experiência que opera uma mistura entre nuances da sensação e variações da excitação, fazendo-nos passar de uma sensação de crescimento à idéia de um crescimento de sensação. Assim, todo o final desse capítulo é dedicado ao exame detalhado da psicofísica, considerada através do seu projeto de medir a sensação. Para ele, pode-se tratar de uma integração de diferenças infinitamente pequenas, como em Fechner (1801-1887), ou da comparação direta de uma sensação com outra (Plateau e Delboeuf), mas este último caso não seria muito diferente do primeiro, cujo erro é o de tomar uma variação qualitativa por uma variação quantitativa e, disto, tirar uma lei que não é mais, no seu entender, do que um prolongamento da crença espontânea do senso comum em "grandezas intensivas", as quais repousam na associação entre o que sentimos de maneira qualitativa e a causa extensiva (mensurável) de nossa impressão - o que é denunciado em todo o capítulo. Fechner partiu de uma lei descoberta por Weber (1795-1878), segundo a qual, sendo dada uma determinada excitação, provocando determinada sensação, a quantidade de excitação que seria preciso acrescentar à primeira, para que a consciência pudesse perceber alguma mudança, estaria em relação constante com ela. No mundo físico, a igualdade não significa identidade, visto que todo objeto ou fenômeno nele se apresenta sob um duplo aspecto: um qualitativo e, outro, extensivo. Porém, nada impede que se faça abstração do primeiro, restando apenas termos capazes de serem sobrepostos uns aos outros, identificando-os, o que não é o caso no mundo psíquico, levando a psicofísica a um contra-senso, porque “esse elemento qualitativo, que se começa por eliminar das coisas exteriores para que a medida seja possível, é precisamente o que a psicofísica retém e pretende medir” (E., p. 47). Segundo Bergson, o que a psicofísica faz é formular com precisão uma concepção do senso comum ou a tendência que nós temos em querer objetivar os nossos estados subjetivos, uma vez que os objetos exteriores são vistos como mais importantes do que eles, introduzindo a representação de sua causa exterior. E, quanto mais percebemos o extensivo atrás do intensivo e a quantidade atrás da qualidade, mais tendemos a colocar o primeiro no segundo e a tratar as sensações como grandezas. Enquanto o objetivo da física seria justamente o de medir ou submeter a causa externa de nossos estados internos ao cálculo, o "momento devia fatalmente chegar em que, familiarizada com essa confusão da qualidade com a quantidade e da sensação com a excitação, a ciência procuraria medir uma como mede a outra: tal foi o objeto da psicofísica” (E., p. 52-3). Nesta tentativa, Fechner teria sido encorajado pelos filósofos que falaram em grandezas intensivas ao mesmo tempo em que declararam os estados psíquicos resistentes à medida. O problema está em tratar as sensações em termos de mais ou menos, maior ou menor. "Ou a sensação é qualidade pura ou, se é uma grandeza, devemos procurar medila” (E., p. 54). No segundo capítulo do livro, Bergson volta-se para a exposição da duração pura, não de modo direto, mas indireto, ou seja, suas características são encontradas a partir da consideração do espaço. Ele analisará vários exemplos para mostrar como ordinarimente pensamos de modo “espacializado” e, ao demonstrá-lo, definirá o que é o tempo real por oposição ao "tempo homogêneo” (espacializado), imagem simbólica da duração real. Ele começa com uma análise do número, definindo-o como “uma coleção de unidades” ou “a síntese do um e do múltiplo” (E., p. 56). Logo, na constituição do número não há qualquer participação do tempo, o que significa que contar nada mais é do que percorrer uma multiplicidade cujas unidades se justapõem no espaço. Desse modo, Bergson afirma que, uma vez admitida essa concepção do número, vemos que todas as coisas não podem ser contadas da mesma maneira e que há duas espécies diferentes de multiplicidades: 1) a que corresponde aos objetos materiais, que se apresentam para a vista e o tato - a característica de ambos é justamente dar os objetos imediatamente num espaço onde os fenômenos são contados; 2) a dos estados puramente afetivos da alma (sentimentos profundos) ou representações outras que as da vista e do toque. "Aqui, os termos não são mais dados no espaço, de maneira que não poderemos contá-los $a$ priori, a não ser por processos de figuração simbólica” (E., p. 64). A distinção entre as duas multiplicidades constitui um dos temas mais relevantes do livro. Segundo Bento Prado Júnior, no livro Presença e campo transcendental, a análise das duas formas de multiplicidade diz respeito à passagem do empírico ao transcendental, do conteúdo da experiência à sua forma. Para ele, o alcance da experiência da duração, no Ensaio, não é apenas empírica e psicológica, mas transcendental, pois concerne aos fundamentos de nossa experiência. Ainda nas palavras do professor Bento: "Dentro do plano geral da crítica do entendimento indispensável à descoberta da duração, a teoria das multiplicidades é uma espécie de estética transcendental [...]. A crítica de Kant é o momento de culminação da crítica em vários níveis que 
constituem pela tentativa de compreender os estados mentais a partir de uma causa material, seja diretamente, considerando a causa material propriamente dita (o cérebro como causa dos estados psíquicos), ou indiretamente, considerando o encadeamento interno à consciência pela projeção do encadeamento dos fatos materiais. No final do século XIX, momento da escrita do Ensaio, as explicações deterministas em grande peso, na explicação dos fenômenos psicológicos, pois são vistas como cientificamente fundamentadas. Num primeiro momento, Bergson aponta as imprecisões dos deterministas, que utilizam, por exemplo, termos e conceitos incapazes de expressar a singularidade da vida psicológica. Pensando nela, é feita a distinção de natureza entre espaço e duração. E é por não ver essa diferença fundamental que os adversários dos deterministas incorrem em erros análogos aos deles, em prejuízo da liberdade. No último capítulo do livro, é ainda no nível, por assim dizer, teórico que a discussão será mantida, cabendo mostrar ao final, inclusive, quais são as concepções metafísicas fundidas (tomadas conjuntamente) e confundidas, portanto, na argumentação corrente do senso comum e na supostamente aprofundada da ciência. Na obra seguinte, Matéria e memória, Bergson refutará o determinismo no nível dos fatos. Entre esta e a posterior, A evolução criadora, faz-se presente, de maneira mais clara, uma preocupação que não é apenas teórica ou empírica, e sim histórica. O filósofo busca as origens das teses deterministas. Se não há respaldo empírico para elas - não são comprovadas pelos fatos - por que se mantêm? O que, de direito, as sustenta? Sua origem não estará no plano físico (referência explícita ou implícita para os deterministas), mas no metafísico, isto é, nas teorias metafísicas concebidas ao longo da história da filosofia. Caberá, então, perguntar pela origem da tese metafísica pressuposta pelos deterministas ao mesmo tempo em que crêem partir da experiência. Trata-se de uma tese efetivamente moderna, construída pelos filósofos mencionados no Ensaio? Como ela entrou nos quadros da ciência contemporânea? A quem cabe o ônus da sua manutenção, sobretudo no que concerne à ciência? Ao filósofo ou ao cientista? E no que diz respeito à própria filosofia, seria ela precisa, ou seja, corresponderia à realidade?

No Ensaio, não é discutida a pertinência filosófica da tese do paralelismo, sua origem e manutenção ao longo da história. Ela é mencionada como exemplo de uma explicação historicamente determinada, que não caberia repetir ou manter, em detrimento das descobertas científicas e daquilo que elas, de algum modo, envolvem: mudanças de perspectiva, ou diferentes visões da vida e do mundo. Ainda que o paralelismo dos “grandes pensadores” não seja diretamente refutado, vários temas ligados a ele são discutidos, e isto se deve à sua indevida permanência como postulados

precede o estalelecimento da ontologia da duração. Assim como a psicofisiologia é, de algum modo, a 'verdade' e a culminação do senso comum, o criticismo é a 'verdade' e a culminação da psicofisiologia” (cf. Presença e campo transcendental, p. 89). Para Bergson, haveria uma continuidade entre Kant e a psicologia de seu tempo. 
científicos, tais como: a relação de causalidade ou ideia de que o "efeito não pode conter mais do que a causa"; o princípio de identidade, ao qual a relação de causalidade "se aproxima indefinidademente"; a lei de conservação de força, que interdita qualquer criação no universo. Temas que remetem diretamente ao mecanicismo e ao cartesianismo. Para Bergson, por exemplo, o desenvolvimento da noção de causalidade, entendida no sentido de uma ligação necessária, conduz à concepção espinosista ${ }^{4}$ ou cartesiana da natureza e, inversamente, toda relação de determinação necessária, estabelecida entre fenômenos sucessivos, provém de que se perceba, atrás dos fenômenos heterogêneos, e mesmo que sob alguma forma confusa, um mecanicismo matemático ${ }^{5}$ (E., p. 157). E, a confiança cega (não verificada pela experiência) no paralelismo ou em seus desdobramentos contemporâneos (o epifenomenismo e o associacionismo), como veremos, nada mais é do que uma sobrevivência da crença sobretudo espinosista no mecanicismo universal e na tese metafísica que a sustenta, construída como sua "razão” ou princípio: a unidade do ser - temas que não estão em princípio presentes no Ensaio.

Ora, quanto mais “o efeito parece necessariamente ligado à causa, mais tendemos a colocá-lo na própria causa, como a consequência matemática no princípio, e a suprimir assim a ação da duração” (E., p. 157). Suprimida a duração, suprime-se também a liberdade. Esta seria a conclusão mais evidente. No terceiro capítulo do Ensaio, contudo, ainda que pareça paradoxal, a suposição de uma relação de inerência matemática entre os fenômenos exteriores acarreta como “consequência natural e plausível”, na causalidade do “tipo espinosista” e na do “tipo leibniziano”, a crença na liberdade humana. No final do capítulo e do livro, após refutar deterministas e seus adversários, demonstrando os equívocos de uns e outros quanto à liberdade, perpetrados, em última instância, pela recusa da duração ou pela confusão do tempo com o espaço, Bergson discute as duas noções de causalidade, ou preformação do futuro no presente, às quais o senso comum chega: uma conduz à concepção de causalidade leibniziana e outra, à espinosista. Nos dois casos, "não se faz mais do que impulsionar ao extremo, ou formular com mais precisão, duas ideias tímidas e confusas do senso

\footnotetext{
${ }^{4}$ Sobre o uso dos termos "espinosista” ou "espinosano", cf. o terceiro capítulo desta tese.

${ }^{5} \mathrm{O}$ "mecanicismo é, antes de tudo, o sistema que visa fórmulas matemáticas ou algébricas, que pretendem explicar fenômenos físicos, por mais complicados que sejam, por equações, e que só considera como real na matéria o que se presta ao cálculo, ou seja, a forma, a extensão e o movimento. O mecanicismo tem, para si, certo número de grandes descobertas deste século e dos anteriores”. Mas, as descobertas da física contemporânea teriam mostrado e esclarecido as numerosas contradições da teoria mecanicista do calor, da ótica ondulatória e da química atômica, e disto resulta que "o mecanicismo, que é o sistema científico por excelência, o mais inteligível pela razão de que é o mais matemático, é apenas uma hipótese cômoda para o espírito, de nenhum modo verificada pela experiência, uma conjectura que autoriza duas ou três grandes leis da física, nada mais” (Cours de psicologie et de métaphysique, $\mathrm{p}$. 333; a data provável de realização desse curso coincide com o momento de realização e publicação do Ensaio, 18881889).
} 
comum” (E., p. 160). Ao contrapor o paralelismo dos "grandes pensadores" ao determinismo dos cientistas, supostamente estabelecido a partir dos fatos empíricos, Bergson, de certo modo, salvaguarda o primeiro de qualquer responsabilidade quanto aos equívocos do segundo. O mesmo valendo para o “problema da liberdade”, já que “cada uma das hipóteses [espinosista ou leibniziana], tomada separadamente, salvaguarda a liberdade humana" e isto "porque toda concepção clara da causalidade, e na qual entendemo-nos conosco mesmos, conduz à ideia da liberdade humana como a uma consequência natural” (E., p. 162). O problema estaria no "hábito contraído" de tomar o princípio de causalidade nos dois sentidos ao mesmo tempo, porque "um seduz a imaginação e o outro favorece o raciocínio matemático”, e não nas duas doutrinas tomadas por elas mesmas, separadamente. As doutrinas dos dois filósofos são apresentadas de modo duplo ou como exemplos distintos: primeiro, como exemplos de uma solução aprimorada, porque rigorosa e construída a partir de uma preocupação metafísica, e, em segundo lugar, como exemplos de uma solução aprimorada, porque formulada a partir de uma tendência do senso comum, que aprimoraram ou lhe deram um acabamento mais refinado. Como interpretar essa duplicidade? Pensamos que, nesse primeiro livro, as filosofias de Leibniz e Espinosa, abordadas apenas no terceiro capítulo, são tratadas de modo duplo porque: num primeiro momento, cabe evidenciar o equívoco do determinismo pela comparação, ainda que breve, com a intenção (metafísica) inquestionável - ou não questionada no Ensaio - do paralelismo; e porque, num segundo momento, cabe ressaltar a “presença de uma ilusão tão profunda, de um preconceito tão tenaz”, que é capaz de manter o apego ao determinismo mesmo quando o determinista aceita argumentos contrários, de modo que "nunca poderemos ter razão sem atacá-los [essa ilusão profunda e esse preconceito tenaz] em seu próprio princípio, que é o princípio de causalidade” (E., p. 152). Assim, a duplicidade pode ser interpretada como algo que se deve a motivos diferentes: o primeiro exemplo do aprimoramento, ao qual nos referimos acima, coloca uma distinção histórica, mencionando uma tese que não pode ser repetida, como afirmamos; o segundo exemplo, por sua vez, explicita uma ilusão ou preconceito que fogem ao campo histórico, uma vez que todos, independentemente da época, estão submetidos a eles, o determinista contemporâneo (os cientistas), o paralelista moderno (os filósofos) e o senso comum. Por isso, deixaremos a análise da relação de causalidade e sua família para outro momento desta tese, uma vez que teremos oportunidade de voltar a essa crença e aos temas a ela relacionados (o princípio de identidade e o de conservação de força) mais adiante, quando estivermos analisando o que ela significa na história da filosofia como algo cuja causa se encontra fora do plano histórico. Por ora, o que nos interessa é constatar que no texto e no contexto do Ensaio, a tese do paralelismo não constitui uma preocupação do autor, assim como o “espinosismo” também não. Cabe voltar, 
portanto, às questões que aventamos acima e que se referem ao aparecimento do paralelismo no Ensaio. Nele, a preocupação de Bergson está direcionada aos problemas postos pelo determinismo de sua época, e o paralelismo não aparece como fonte dos erros ou equívocos contemporâneos. O livro, de qualquer modo, já indica uma relação entre ambos, que pode ser revelada, por exemplo, pelo fato de que no fundo tanto do paralelismo quanto do determinismo (físico ou psicológico) está o mecanicismo. Podemos afirmar que, no Ensaio, o determinista é responsabilizado por seus equívocos ou extrapolações, ainda que haja uma influência filosófica sobre as suas considerações, no que diz respeito à noção de "grandeza intensiva”, por exemplo. Algo que se inverterá, quando a tese do paralelismo aparecer a Bergson como uma "tese simples", mantida pela ciência (como "postulado oculto”) porque "os filósofos não se deram ao trabalho de buscar outra”6.

A causalidade tomada como referência, seja para o simples encadeamento dos estados de consciência, seja para a redução da consciência a uma fosforescência, está ligada à tese do mecanicismo, e toda vez que se afirma uma causalidade mecanicista, faz-se um retorno à filosofia dos cartesianos - Espinosa e Leibniz, como exposto no próprio Ensaio. De todo modo, as teses sustentadas pelos filósofos clássicos são justificadas, digamos, pela distinção histórica. Ou seja, não se pode admitir que sejam transportadas para outro momento histórico, com o qual não condizem ou para o qual não são adequadas, mas isto não as invalida em si mesmas, pelo contrário, as justifica pela adequação ao seu momento histórico, e as isenta de qualquer responsabilidade em face dos equívocos atuais. Nos trabalhos futuros, ao ser afirmada a origem histórica - o vínculo entre o paralelismo e as terias psicológicas ou fisiológicas contemporâneas -, os equívocos das últimas recairão em boa parte sobre a tese metafísica que as sustenta. E isto porque, ao assumir implicitamente a causalidade mecanicista, o cientista faz, de acordo com Bergson, uma opção por um tipo de tese metafísica, mas ele pode não ter disto a menor ideia, tal como será considerado futuramente:

Supor a priori que a totalidade do real é resolúvel em elementos desse gênero [próprios ao mecanicismo], ou, ao menos, que o mecanicismo poderia dar uma tradução integral do que se passa no mundo, é optar por uma determinada metafísica, aquela mesma da qual um Espinosa e um Leibniz puseram os princípios, tiraram as consequências. Decerto, um psicofisiologista que afirma a equivalência exata do estado cerebral e do estado psicológico, que se representa a possibilidade, para alguma inteligência sobre-humana, de ler no cérebro o que se passa na consciência, acredita-se bem longe dos metafísicos do século XVII, e muito perto da

\footnotetext{
6 “O paralelismo psicofísico e a metafísica positiva” (Mélanges, p. 484).
} 
experiência. No entanto, a experiência pura e simples não nos diz nada de semelhante (E.C., p. 353; grifo nosso).

A tese que sustenta as suas escolhas e interpretações dos fatos empíricos é anterior à experiência e, no caso da psicofisiologia, foi construída antes mesmo que essa ciência tivesse nascimento, fornecendo-lhe de antemão os seus quadros e princípios - é por isto que se trata de sua “metafísica inconsciente”. De onde vem a força de tal tese ou sua incontornável influência? O exame crítico de Bergson no que concerne à busca genealógica do paralelismo explicitará o que o faz tão irrecusável, e como ele entrou nos quadros da ciência atual, sem qualquer confirmação empírica. Passaremos à análise dos trabalhos nos quais a origem das teorias deterministas é buscada, revelando a origem histórica da própria tese do paralelismo, os motivos pelas quais ela se manteve como explicação metafísica e científica para a relação psicofisiológica e as consequências dessa permanência.

No ano escolar de 1903 a 1904, Bergson ministrou no Collège de France um curso cuja primeira parte tinha como objetivo o estudo e a crítica das teorias contemporâneas da memória ou dos procedimentos usados pela psicologia. Nas últimas aulas do curso, o professor refaz a história dessas teorias por meio de um estudo de determinadas doutrinas filosóficas, cujo objetivo consiste em mostrar a origem metafísica da teoria psicofisiológica da memória. No início do segundo semestre, o objetivo da segunda parte do curso é explicado...

Sabemos que o objeto que nós perseguimos é dogmático e teórico, tanto quanto ou mais que histórico. Nós mostramos, na primeira parte do curso, que a explicação mais corrente, mais ordinária dos fenômenos da memória implica, de uma parte, uma concepção associacionista da vida do espírito e, de outra parte - ideia expressa ou latente -, que as lembranças só se conservam no espírito porque se conservam materialmente; haveria como que um depósito, sob uma forma ou sob outra, de lembranças na substância cerebral. Tentamos estabelecer que os fatos em geral, os fatos normais e os fatos patológicos, estão longe, tanto quanto possamos crer, de confirmar essa hipótese, donde termos inferido que ela, a despeito de sua aparência empírica, é verdadeiramente apenas uma forma, uma forma de certas crenças, talvez mesmo de certos preconceitos metafísicos, mas muito natural e muito profunda, tão natural e tão profunda que é necessário um esforço considerável de espírito para dela se libertar. São esses postulados metafísicos que desejamos salientar, na segunda parte do curso, e isto por um esboço muito rápido da própria evolução que essa hipótese efetuou (Annales 
bergsoninnes $I I^{7}$, p. 42).

Consideramos necessário indicar, em primeira instância, a importância desse curso para o nosso trabalho, por meio de uma breve comparação entre ele e a história dos sistemas de A Evolução criadora. Num primeiro momento, poderíamos ser levados a situar tal curso como um intermediário apenas entre Matéria e memória (1896) e A Evolução criadora (1907). Ele mostra, primeiramente, que os fatos não confirmam as teorias psicológicas estudadas (associacionismo e epifenomenismo) e, então, conclui que são versões de algo dogmático e teórico, de uma crença natural e profunda em certos postulados metafísicos. Ou seja, ele parte dos resultados do livro publicado que o precede e teria, por assim dizer, sua versão mais acabada no livro que o sucede. Porém, se ele retoma, em sua primeira parte, a abordagem dos fatos empíricos, feita em Matéria e memória, não encontramos em A Evolução criadora a versão definitiva do mesmo, o que tornaria seu estudo quase dispensável. Muitas de suas análises são retomadas, parcial ou aprofundadamente, no quarto capítulo do livro, mas o tratamento de alguns temas é feito de modo diverso. Isto se deve ao próprio fato de que a “história dos sistemas filosóficos”, apresentada no livro, insere-se nos resultados dessa obra, o que não significa uma simples ampliação do exame histórico das relações confusas entre ciência e filosofia, mas uma retomada histórica a partir de outra perspectiva - já presente no curso, mas que não constituía, por assim dizer, o seu foco, qual seja, a causa natural dos "preconceitos metafísicos”.

No curso, como vimos no trecho citado, a parte voltada para a análise empírica dos fatos demonstra que o objeto buscado não pode ser obtido pela experiência, o que faz dele algo não somente teórico, mas dogmático, porque, sem fundamento, seria mais uma crença ou um preconceito. Em princípio, a hipótese sustentada ou mantida pelas teorias da memória, em qualquer das versões analisadas, sendo apenas dogma, crença ou preconceito, ultrapassa o domínio histórico: é uma "forma" que independe da prática ou conteúdo que deveria lhe corresponder e, consequentemente, independe do momento em que é reformulada ou retomada. Todavia, o objetivo da segunda parte do curso é o de revelar os postulados metafísicos que se mantêm como crença, de modo a eliminá-la, o que só pode ser obtido por um “esforço considerável de espírito”. Em que consiste esse esforço senão na reconstituição “da própria evolução que essa hipótese efetuou”? O esboço rápido dessa evolução, devido às poucas aulas que restam, desvenda a história dessa hipótese: mostra a sua origem histórica e, ainda mais, a sua renovação nos diferentes momentos em que é incorporada às descobertas ou transformações científicas. Assim, tal objeto de estudo é tanto

\footnotetext{
${ }^{7}$ Doravante “Annales II”.
} 
dogmático quanto histórico, e o próprio dogma só pode ser desconstruído por um esforço que é também uma reconstrução histórica, ainda que não o seja exclusivamente. Isto é o que o exame crítico e histórico intenta fazer, o que pode ser visto no referido curso, no primeiro artigo em que a história dos sistemas filosóficos adquire um lugar de destaque no pensamento de Bergson, "Introdução à metafísica” (1903), no quarto capítulo de A Evolução criadora, mesmo que, nele, outra perspectiva se faça presente de modo mais contundente, e no artigo "A alma e o corpo" (1912), apogeu da crítica histórica. Centraremos nossa análise no curso sobre a "História das teorias da memória”, porque o cerne de seu estudo é essa reconstituição histórica, que se encontra inserida nos outros textos apontados, porém sob perspectivas um pouco distintas (às quais faremos menção) e sem o desenvolvimento mais detido de referências que nele encontramos ${ }^{8}$. Algumas de suas análises não estão presentes em nenhum livro publicado, ou se encontram em estado embrionário.

Duas são as asserções principais do curso em questão, quanto ao tema que nos interessa: uma inscreve a origem do paralelismo na filosofia antiga, mais especificamente aristotélica, e a outra afirma o caráter paradigmático do paralelismo de Espinosa.

Na primeira aula, vemos que o paralelismo dos antigos é uma espécie de consequência da concepção que eles têm de verdade, qual seja: o postulado de que existiria uma ciência una e integral, um sistema de verdades científicas pronto e independente de nossas inteligências individuais, e que conhecer seria apenas clarear pontos diferentes desse mundo inteligível (Annales II, p. 45). Os inteligíveis são conceitos e ideias que constituem a ciência una ou o mundo inteligível - constituem a unidade da realidade inteligível. Com Aristóteles, a verdade, acordo entre o intelecto e a coisa, é representada como a estrutura lógica da realidade, e o mesmo vale para Platão. O físico é, assim, definido pelo lógico, visto que, sob os fenômenos que mudam, há um sistema fechado de conceitos subordinados e coordenados entre si. A concepção de realidade estará intrinsecamente ligada à de verdade, pois a ciência, entendida como sistema de conceitos, será mais real que a realidade sensível, assim como as ideias ou conceitos serão mais reais que os objetos dados à nossa experiência.

Para Bergson, a psicologia antiga abarcaria uma parte descritiva, voltada para o tratamento das emoções ou paixões (parte afetiva de nossa natureza, cujo estudo seria da competência tanto do psicólogo quanto do moralista) e uma parte que se ocuparia mais sistematicamente dos fenômenos

\footnotetext{
${ }^{8} \mathrm{Na}$ "história dos sistemas filosóficos” de A evolução criadora, por exemplo, a comparação entre a ciência antiga e a ciência moderna é mais explorada. Por outro lado, algumas referências são suprimidas, tais como a presença de germes do paralelismo moderno na filosofia antiga (o que é uma das teses de maior destaque na segunda parte do curso, diversas vezes reiterada) e a importância, para a filosofia moderna, da concepção de percepção presente em Galeno.
} 
da inteligência. Esta conhece os objetos, é um instrumento de conhecimento e como tal deve se adaptar ao objeto de conhecimento. O problema é que a inteligência não foi tomada nela mesma, já que muito raramente um psicólogo faz uma "pura psicologia da inteligência”. Como os antigos partiam de certa concepção da verdade e da realidade, e como o instrumento deve ser adaptado ao objeto, a forma do instrumento foi definida pela forma do objeto a conhecer, ou seja, pelos conceitos ou ideias que constituem a realidade inteligível, estável e imutável. Neste ponto, antigos e modernos coincidiriam, o que explica o acordo entre eles, mesmo quando parecem distantes e divergentes, pois têm o mesmo fundo comum, como veremos.

Da concepção de verdade dos antigos, segue que o real é a ciência, ou o mundo da ciência, a qual preexiste ao conhecimento propriamente dito, e isto a que chamamos de realidade toma sua realidade - seu ser - daquilo que ela tem, ou possa ter, em comum com o mundo uno e coerente da ciência. Na psicologia de Aristóteles, referência principal para a explicação do pensamento antigo ainda que algumas vezes ele seja substituído por um recurso aos Alexandrinos, sobretudo Plotino, cuja filosofia, de acordo com Bergson, poderia "representar o papel de lupa para examinar as filosofias de Platão e Aristóteles” (Annales II, p. 52) -, haveria um tipo de conhecimento intemporal, ligado à teoria da inteligência propriamente dita ou do pensamento puro (sobre a qual Aristóteles “infelizmente, não disse quase nada”), e um conhecimento temporal, pela alma, que só é possível quando a inteligência nela se introduz - é o conhecimento pela inteligência discursiva. E, abaixo de tudo isso, haveria as faculdades da alma, a percepção e a memória, operações comuns à alma humana e aos animais, os quais não participam em nada do mundo dos inteligíveis. O germe do paralelismo moderno estaria em Aristóteles (e teria sido desenvolvido pelos Alexandrinos), podendo ser apreendido na sua maneira de definir a relação entre o inteligível (coisa) e a inteligência (pensamento) ${ }^{9}$. Trata-se de um paralelismo entre o objeto de conhecimento que se situa no mundo da ciência - das Formas - perfeitamente coerente e lógico, e o instrumento do conhecimento, o pensamento ou a inteligência, que contém a ciência em potência - é o lugar das Formas. Destarte, a concepção antiga do paralelismo o circunscreve na esfera do inteligível.

O curso apresenta extraordinariamente ${ }^{10}$, assim, a origem do paralelismo na filosofia antiga,

\footnotetext{
9 Antes de afirmá-lo, Bergson explica a diferença entre “coisa” e "idéia ou pensamento” para os antigos, concluindo que a primeira era muito menos “coisa” do que a entendemos, e a segunda muito menos “idéia” - distinção constantemente reiterada no curso.

${ }^{10}$ Em A Evolução criadora, as origens antigas da metafísica moderna são afirmadas, mas não há nenhuma referência a um paralelismo antigo. Em “A alma e o corpo”, o epifenomenismo será definido como uma "velha mercadoria”, referindo-se explicitamente aos filósofos modernos (Leibniz e Espinosa). Pensamos, contudo, que tal afirmação, nesse texto de 1912, pode também ser lido como uma alusão ao paralelimo antigo, o que seria, digamos, mais fiel inclusive ao teor do quarto capítulo de A Evolução, que acaba por afirmar o caráter antigo - grego - da metafísica.
} 
pois...

Como dissemos, encontra-se em Aristóteles o esboço, o germe dessa doutrina, desenvolvida pelos Alexandrinos, qual seja, a de que a inteligência e os inteligíveis são regulados um pelo outro e se correspondem absolutamente, como duas faces ou duas expressões equivalentes de Deus, da unidade divina superior à inteligência e ao inteligível. É algo como o côncavo e o convexo. Pensem em uma bacia, côncava de um lado e convexa de outro; é a mesma coisa vista sob dois aspectos diferentes. O mesmo se passa, nos Alexandrinos, em relação à inteligência e os inteligíveis. Se comparamos os inteligíveis uns aos outros, cada um é todos os outros e regulados pelos outros; não há influência recíproca, mas há uma correspondência estreita e tudo isso se passa como se houvesse influência porque estamos em presença de dois estados, de dois aspectos ou de duas expressões de uma única e mesma unidade (Annales II, p. 111).

O paralelismo antigo (e o mesmo valerá para o moderno) é consequência da unidade da realidade e de sua definição intrinsecamente ligada à de verdade científica. O conhecimento do "ser" é dependente do conhecimento da verdade, cuja sistematicidade é posta pela ciência como préexistência. Unidade de ser e unidade de saber se correspondem, pois a realidade empresta seu ser do mundo da ciência e o conhecer se define pela conquista das verdades previamente existentes “reconhecer”11. Considera-se que há um sistema único e perfeitamente coerente, uma unidade continente e subjacente a todas as multiplicidades, na qual todas elas viriam "se abismar". O paralelismo é, portanto, dependente da concepção de ciência. Na antiguidade, para Bergson, filosofia e ciência não podem ser completamente separadas, e a filosofia seria uma sistematização da ciência, postulando um princípio unificador do conhecimento - trata-se de um único sistema de saber ${ }^{12}$. No que se refere à filosofia antiga, o paralelismo restringia-se à esfera da realidade inteligível - unidade entre Ideias (ou Fomas) e aquilo que as conhece. Quanto ao mundo sensível, não haveria paralelismo, mas intercomunicação. Isto é o que distinguirá o paralelismo moderno do dos antigos.

A filosofia moderna fará a transposição do paralelismo para o mundo sensível - transposição necessária por causa das mudanças operadas pela ciência moderna. Porém, o postulado fundamental de toda ciência, antiga ou moderna, segundo Bergson, "foi dado por Aristóteles, quando ele disse

\footnotetext{
${ }^{11}$ No caso dos Alexandrinos, seria um retorno ao Uno, do qual todas as coisas saem (processão) e, ao qual, todas retornam (reversão).

${ }^{12}$ Lemos, em A Evolução criadora, a respeito da Antiguidade, que: "sua ciência consistia em uma metafísica espalhada e fragmentária, sua metafísica em uma ciência concentrada e sistemática: tratava-se, no máximo, de duas espécies de um mesmo gênero” (E.C., p. 372).
} 
que não há ciência do que é individual ou mutável. A ciência só atinge o permanente, o constante e também o geral” (Annales II, p. 94), ou seja, uma ciência que se pautasse pelo individual ou mutável não seria ciência. Com a ciência moderna, uma novidade na concepção do tempo se faz presente (o tempo passa a ser considerado uma variável independente), mas ela não consegue seguir na direção dessa intuição e novamente se perde nos quadros analíticos, o que terá como efeito a afirmação de um novo paralelismo. A oposição entre, de um lado, a mudança e a individualidade, e, de outro, o constante, invariável e universal, para a qual a ciência se volta, é resolvida diferentemente por filósofos antigos e modernos. Os primeiros farão das coisas mutáveis (sensíveis) uma degradação do mundo da ciência, das coisas absolutamente reais. Os outros partirão da mudança (ela é, diferentemente do que consideravam os antigos, uma realidade que deve ser estudada, e não o signo de que algo não estaria onde deveria) e estabelecerão, entre as coisas que mudam, uma relação invariável. Estabelecerão leis, relações fixas entre grandezas variáveis, reafirmando a imutabilidade e a universalidade que a ciência, em geral, exige. A oposição aparente entre ambas as ciências - a antiga é transcendente ao mundo sensível, enquanto a moderna é imanente a ele -, não dissimula o mesmo fundo comum: o postulado aristotélico fundamental.

A verificação de tal postulado no mundo sensível não é um problema para a ciência. O problema, como sabemos, ocorre quando a filosofia estende os mesmos procedimentos válidos no plano físico (tomado na modernidade por uma rede de relações estáveis), para a totalidade da realidade. E é nessa ampliação que se insere o paralelismo moderno. A mudança de perspectiva na ciência moderna (imanência e não mais transcendência) não se faz sem uma mudança na explicação da realidade e, no que diz respeito ao interesse maior do curso sobre a história das teorias da memória, sem uma mudança no papel da memória nas diferentes teorias. Por isso, ela é fundamental para a compreensão da crítica de Bergson à psicologia, pois ele entende que a psicologia "sempre esteve calcada na metafísica” e que essa diferença capital entre antigos e modernos teve para a psicologia “consequências de primeira importância” (Annales II, p. 97). Em todo caso, para antigos e modernos em geral, a teoria da memória é preparada pela da percepção.

No caso dos antigos, há que se levar em conta a distinção primeira entre inteligência, que se ocupa com a ciência (mundo inteligível), e as faculdades da alma (percepção e memória), que se ocupam com as coisas sensíveis. Enquanto a inteligência só se exerce sobre coisas superiores ao mundo sensível, a percepção é a faculdade de conhecimento segundo o acidente ou a disposição das coisas no tempo e no espaço (diferentemente do plano lógico, das Formas perfeitas, não submetidas ao tempo). A alma pode, inclusive, ser representada por uma “descida ao organismo”, um prolongamento dos órgãos dos sentidos (Annales II, p. 72). A percepção, obra comum entre o 
sujeito que percebe e o objeto percebido, possibilita que este conduza ao ato o que aquele (órgãos dos sentidos) tem em potência. Não há paralelismo entre "sujeito do conhecimento" e "objeto conhecido”, e sim intercomunicação. Como o objeto material é capaz de se conservar, a alma é dotada de memória, de modo que há sobrevivência das percepções e das imagens enquanto tais. Na percepção, a qualidade dos objetos exteriores entra em nós e, na memória, a própria percepção sobrevive. A alma, mesmo não sendo material, participa da existência da matéria, é consciente no homem e no animal porque a consciência pertence à alma e ao corpo organizado, não tendo uma função ou lugar determinado. Percepção e memória seriam, portanto, coisas menos intelectuais do que para os filósofos modernos, cuja definição geométrica da matéria e cuja concepção psicológica da consciência (completamente anímica ou intelectual) tornará difícil tanto uma espécie de conservação integral das coisas percebidas, quanto uma representação da consciência penetrando a matéria ou, mais particularmente, os órgãos sensoriais.

No caso dos modernos, a ciência estabelece relações estáveis entre as coisas que a percepção nos mostra e que a memória retém. Entendimento, percepção e memória são faculdades que não diferem mais radicalmente entre si. Tudo “o que é consciência [percepção, memória e inteligência] passa para o lado do espírito”, só restando “à matéria tudo o que é absolutamente estranho à consciência” (Annales II, p. 98). Ao ser retirada toda espécie de consciência do domínio da materialidade, só lhe restam as propriedades puramente geométricas: a matéria e a corporalidade passam a ser definidas pela extensão ${ }^{13}$. Essa concepção moderna torna mais cômodo o estudo do mundo físico, uma vez que não temos necessidade de sair da realidade sensível, mas levanta dificuldades consideráveis do lado psicológico ou da relação possível entre a alma e o corpo, maiores do que as conhecidas pelos antigos. Trata-se de um problema essencialmente moderno, pois a oposição estabelecida por Descartes entre o pensamento e a extensão (a consciência e a matéria) levou-o a um estado agudo e, mesmo, insolúvel. Desse modo...

Foi por ter cortado todo vínculo entre os dois termos que os filósofos foram conduzidos a estabelecer entre ambos um paralelismo rigoroso no qual os antigos sequer haviam pensado, a tomá-los por traduções e não inversões um do outro, enfim, a dar à sua dualidade o substrato de uma identidade fundamental. [...] É esse paralelismo que encontramos tanto em Leibniz quanto em Espinosa, sob formas diferentes, é verdade, por causa da desigual importância que atribuem à extensão (E.C., p. 378).

\footnotetext{
${ }^{13}$ Como veremos na abordagem empírica, a concepção metafísica da matéria do último capítulo de Matéria e memória não define a matéria pela extensão, uma vez que ela participará da própria tensão, que define a duração. A diferença de natureza permanece, mas é afirmada ao mesmo tempo uma diferença de grau entre elas. São graus diferentes de tensão.
} 
Ao ler essas linhas de A evolução criadora, sem vinculá-las ao curso sobre as teorias da memória, podemos ser levados a interpretar o paralelismo como algo moderno porque inexistente antes, no qual “os antigos sequer haviam pensado”. Quando, de fato, ele é moderno não porque não tenha existido, de direito, um paralelismo antigo, mas porque a sua construção moderna é tão rigorosa e atraente ao espírito, a ponto de não se equiparar a nada, nem mesmo ao paralelismo antigo. O curso tem a pretensão de mostrar a evolução dessa hipótese, cuja origem é encontrada na filosofia antiga, o que constitui uma de suas teses principais, diversas vezes reiterada. Ora, sabemos que Bergson considera essa filosofia como uma fonte inesgotável para as posteriores, sobretudo no que diz respeito ao dualismo, do qual todos os outros seriam suas versões. O dualismo platônico, particularmente, teria gerado todos os dualismos que se constituíram ao longo da história da filosofia. No curso, contudo, Platão assume um papel mais secundário, e a origem do paralelismo é encontrada, como vimos, em Aristóteles, sendo a sua explicação feita com a ajuda dos Alexandrinos $^{14}$. O que $A$ Evolução põe é o aprimoramento ao máximo (inigualável e incomparável) da tese do paralelismo ${ }^{15}$. É por isso que, com os filósofos modernos, surge um problema inexistente para os antigos: o problema da liberdade. Ainda que eles o tenham conhecido, não se tratava de um verdadeiro problema, mas de uma questão como todas as outras. A separação cartesiana entre o extenso e o inextenso, colocada por Descartes e levada ao extremo por seus discípulos, dos quais Espinosa seria o mais fiel, estabelece praticamente uma impossibilidade de superação nos termos postos, gerando o "problema da liberdade, o qual é somente outro aspecto do mesmo problema” (Annales II, p. 99) - o paralelismo como resposta ao problema da relação entre a alma e o corpo uma vez posta a separação abissal entre ambos. A dissolução do problema da liberdade só poderá ocorrer, portanto, pela anulação do problema do paralelismo, ou pela reconsideração do vínculo entre ciência e metafísica, o que deverá levar a uma problematização da própria concepção de unidade do saber, bem como daquilo que é pressuposto por ela: a unidade do ser. O curso aponta essa mudança de foco, que será mantida nos textos posteriores em que tal problemática é tratada: é preciso combater, mais do que o próprio determinismo, a sua fonte, e é de seu aniquilamento que a liberdade surgirá. Ele apresenta a origem da crença na unidade do ser e do saber ao afirmar que a

\footnotetext{
${ }^{14}$ Ao falar nos Alexandrinos, Bergson está pensando em Plotino principalmente.

${ }^{15} \mathrm{O}$ curso aponta a diferença entre a concepção antiga da relação entre a alma e o corpo (intercomunicação) e a concepção moderna do paralelismo, dizendo que a primeira não tem nenhuma semelhança com a segunda (Annales II, p. 88).
} 
inteligência nunca fora questionada como instrumento de conhecimento. Caberá ao texto de $A$ Evolução criadora, como sabemos, o estudo detalhado dessa faculdade, seu alcance e limites, de modo que a história dos sistemas, apresentada no final do livro, revele o mecanismo natural do erro filosófico. Ao curso cabe o inventário das teorias da memória, a partir do exame evolutivo de sua tese fundamental, revelando suas mutações com um apelo mais detido às invenções ou hipóteses científicas, o que dá a ele um tom “mais histórico”16.

A teoria moderna do paralelismo psicofísico, como não poderia deixar de ser, origina-se na separação cartesiana entre processos materiais mensuráveis, de um lado, e estados psíquicos ou intelectuais, de outro. Tanto o curso quanto o último capítulo de A evolução criadora afirmarão Descartes como o criador do paralelismo, ao mesmo tempo em que negarão que ele seja o responsável por sua radicalização e, consequentemente, por seus problemas. Para Bergson, Descartes é um dos raros filósofos que afirmam a liberdade humana. Lemos na história dos sistemas filosóficos que ele, mesmo postulando o mecanicismo universal, por crer no livre-arbítrio, sobrepôs o indeterminismo das ações humanas ao determinismo físico, o que significa sobrepor "ao tempocomprimento uma duração na qual há invenção, criação, sucessão verdadeira” (E.C., p. 373). Claro está que o filósofo teria apoiado essa duração em um Deus, criador e renovador da criação, tangente ao tempo e ao devir, sustentando-os e comunicando-lhes algo de sua realidade absoluta. Contudo, não levara nenhuma das vias ao fim. Se não levou a criação continuada (por Deus) até o ponto em que ela se tornaria contínua (uma evolução verdadeira do universo em seu conjunto), também não fez do mecanicismo uma doutrina. Ainda que o mecanicismo, do ponto de vista histórico, tenha sua justificativa ontológica em Descartes, que fez da substância extensa um conjunto de movimentos e relações mecânicas, para Bergson, ele (o mecanicismo de Descartes) seria, antes, um método, já que não teria sido estendido ao todo da realidade. Seus sucessores, ao contrário, teriam convertido a regra geral do método científico, de acordo com a qual é útil proceder como se todos os sistemas materiais satisfizessem a condição desejada para o cálculo e a previsibilidade, em lei fundamental das

\footnotetext{
${ }^{16}$ Henri Gouhier, em Bergson dans l'histoire de la pensée occidentale, ao escrever sobre "L'histoire bergsonienne de la philosophie" (sétimo capítulo do livro), compara o último capítulo de A evolução criadora com o curso sobre a "Histoire de l'idée de temps dans ses rapports aves les systèmes", ministrado no Collège de France em 1902-1903. No seu entender, o último capítulo do livro tem uma finalidade filosófica: "situar o bergsonismo na história da filosofia e em sua própria história”, enquanto o curso tem uma finalidade propriamente histórica: “uma história da idéia de tempo 'em suas conexões com os sistemas' vai fornecer ao autor de A evolução criadora o dossiê dos 'sistemas', do qual ele terá necessidade em um último capítulo” (Cf. GOUHIER, H. Bergson dans l'histoire de la pensée occidentale. Paris: Vrin, 1989, p. 73). Pensamos que o mesmo pode ser afirmado em relação ao curso com o qual nos ocupamos aqui, sua preocupação seria mais histórica (reconstituir os momentos históricos que, de um modo ou de outro, moldaram as concepções atuais da consciência ou da memória), enquanto a história dos sistemas de $A$ evolução criadora se faria a partir dos interesses e resultados do livro, revelando mais a perspectiva da origem não histórica da tese do paralelismo, que, de todo modo, o curso menciona.
} 
coisas, desembocando em um mecanicismo universal. Fizeram mais: deram a razão do mecanicismo; formularam a unidade de um princípio em que tudo se encontraria contraído, tanto o que há de justaposto no espaço, quanto o que há de sucessivo no tempo: “o ser verdadeiro, indivisível e eterno”. E “desde então, supunha-se dada de um só golpe a totalidade do real” (E.C., p. 376). Também o curso, ao colocar a dificuldade de resolução do problema da liberdade em termos modernos, uma vez que a ciência se torna a concepção de relações estáveis ou matemáticas entre todos os fatos do universo, o qual assume a forma de uma máquina ou de um imenso mecanismo (sem que haja lugar para acasos ou contingências), faz ver que tal é a fórmula do cartesianismo, mas não necessariamente de Descartes ${ }^{17}$. Se Descartes é o inventor da teoria paralelista, ele atenuou a sua expressão e foram os "seus discípulos que, indo até o seu extremo, como fazem geralmente os discípulos, exageraram o pensamento do mestre, chegando à idéia de um paralelismo rigoroso entre o físico e o psíquico” (Annales II, p. 88). Não havendo ação recíproca entre ambos, haveria uma correspondência absoluta e rigorosa, e tal é a fórmula metafísica dessa doutrina. A fórmula “mais científica”, o epifenomenismo, seria uma versão ou atenuação dela, constituindo um cartesianismo estreito e diminuído, como veremos. O curso apresenta algo único, em relação à obra publicada: mostra que o paralelismo de Descartes, ou melhor, que a teoria do conhecimento que está na sua fonte, qual seja, a idéia de que um estado de consciência pode ser excitado pelo movimento de espíritos animais, não fora, nas palavras de Bergson, "produzida como um deus ex machina, não saiu subitamente do nada, mas foi preparada, em particular pelos trabalhos dos médicos continuadores de Galeno” (Annales II, p. 89).

Segundo o professor, a hipótese de que o cérebro seria o órgão principal da alma pode ser encontrada nos Pitagóricos e mesmo em Platão. Com Galeno, não se trataria mais de uma simples hipótese, e sim de argumentos de fato. Ao estudar o que se passa no caso de um ataque de apoplexia (acidente vascular cerebral), Galeno descobre que, se há uma lesão no cérebro, há abolição da percepção e da faculdade de perceber formas e imagens, o que o faz chegar à conclusão de que o cérebro é o órgão interessado nessa operação. "Eis a demonstração à la moderne para o fato" (Annales II, p. 90). Ele localiza no cérebro o essencial dos fenômenos da percepção e da memória. Para explicar como a percepção chega ao cérebro, recorre a uma hipótese, não inventada por ele ${ }^{18}$, mas à qual "dá uma forma destinada a uma grande sorte”: os espíritos animais, alguma coisa que seria como aquilo que atualmente se chama de fluido nervoso - algo material, porém muito sutil,

\footnotetext{
17 “A fórmula do cartesianismo, não digo a fórmula do próprio Descartes, a fórmula em termos matemáticos modernos é a de que 'tudo é função de tudo'” (Annales II, p. 100).
} 
constituindo um fluido que circula através dos nervos, levando impressões (da periferia ao centro ou cérebro) capazes de subsistir, o que forma a memória (Annales II, p. 90). Em todo caso, não haveria, nessa concepção, qualquer traço da teoria cartesiana inovadora segundo a qual os espíritos animais seriam um fato fisiológico e espacial, enquanto a consciência seria algo psíquico e inextenso.

O médico Galeno levara a hipótese do cérebro, como órgão principal da alma, para o nível dos fatos (pelo estudo das lesões e a consequente perda da faculdade de perceber), ao mesmo tempo em que lançara mão de uma hipótese - os espíritos animais - que não pode ser comprovada pela experiência, e que avançará para a teoria moderna da relação entre o físico e o psíquico. Esta não será uma repetição da antiga, já que "não há, em todo caso, rastro de uma teoria como a de Descartes”: será algo novo. De todo modo...

\begin{abstract}
Descartes é o verdadeiro criador da teoria moderna de uma simples correspondência entre os estados cerebrais ou outros, sobretudo cerebrais, e os estados de consciência que lhes correspondem rigorosamente ponto por ponto, os elementos físicos e morais se correspondendo cada um a cada um, como dizem os matemáticos, se correspondendo ponto por ponto, ainda que, no entanto, não possa nunca haver contato entre eles, porque são duas ordens de coisas absolutamente diferentes, o psíquico, que é o inextenso, e o físico, o essencialmente extenso. Essa teoria cartesiana, que nem de longe tem tal rigor inflexível no próprio Descartes, deu nascimento, de um lado, às doutrinas metafísicas para as quais haveria como que uma harmonia estabelecida entre o físico e o moral, o corpo e o espírito, os quais dizem a mesma coisa, mas o dizem em duas línguas diferentes, e não se influenciam mais do que se influenciam duas traduções de uma mesma página [...]; podemos estar certos de que, a um estado de consciência determinado, corresponde um estado cerebral perfeitamente determinado. Eis a forma metafísica da doutrina. Há outra mais científica, a que é adotada pela maioria dos cientistas e que consiste em dizer que o fato de consciência, o estado psicológico se acrescenta ao estado cerebral, sendo determinado quando o fato cerebral é determinado (Annales II, p. 91-2).
\end{abstract}

Descartes está na origem da fórmula metafísica do paralelismo (correspondência), bem como da fórmula "mais científica", sustentada pelos psicofisiologistas tempos depois. Ele é o inventor do paralelismo porque separou os domínios do físico e do psíquico e porque forneceu o meio de reunilos com a teoria dos espíritos animais - teoria esta preparada anteriormente, mas distinta das precedentes justamente pela cisão que ela vinha resolver. Contudo, por não ter estendido o determinismo do plano físico para o plano moral, mantendo um indeterminismo nas ações humanas,

\footnotetext{
${ }^{18}$ Aristóteles e os estóicos já teriam falado neles.
} 
não recairão sobre ele as consequências do paralelismo. O mesmo ocorrerá com a teoria dos espíritos animais como fonte da psicofisiologia nascente. Na penúltima aula, como veremos, ao analisar algumas proposições da Ética, Bergson reencontra os espíritos animais de Descartes que, remodelados pelo rigor espinosista, vão passar para algumas teorias contemporâneas da memória, como a última aula explicita.

Dentre os cartesianos responsáveis pela transposição necessária do paralelismo antigo, tendo em vista as transformações científicas ou pesquisas físico-matemáticas modernas, Espinosa será colocado no centro da explicação e os outros dois, Leibniz e Malebranche, “orbitarão à sua volta”. Isto diferencia bastante o curso sobre a história das teorias da memória e a história dos sistemas de $A$ Evolução criadora, uma vez que, no último capítulo desse livro ${ }^{19}$, Leibniz e Espinosa aparecem sempre juntos, no que se refere ao paralelismo, formando um par quase indissociável. Já no curso, a separação é enfaticamente colocada, de modo que, para se ter da tese do paralelismo "uma expressão mais precisa e rigorosa, é incontestavelmente em Espinosa que é necessário buscá-la”, pois “todas as vezes que uma hipótese desse gênero [na qual pensamento e extensão são definidos de modo que não haja contato ou influência possível entre ambos] é de fato rigorosa e consequente consigo mesma, é no espinosismo que ela chega” (Annales II, p. 123-4).

Bergson dedica a segunda parte ${ }^{20}$ da penúltima aula do curso à exposição da doutrina de Espinosa, cujo rigor arrasta tudo consigo, inclusive o próprio Descartes. Juntamente com o paralelismo espinosano, será exposto o esquema fundamental de todas as teorias psicofisiológicas, bem como a própria teoria da associação de idéias, a qual, a partir de agora, será diretamente vinculada ao espinosismo. Assim, pela primeira vez no curso (na parte sobre a história das teorias da memória), Bergson recorre ao texto do filósofo ${ }^{21}$ abordado, e cita algumas proposições da Ética. Certamente, se houvesse mais tempo, poderia se dedicar a muitas outras, pois, para "ver essa espécie de paralelismo exposta com seu máximo de rigor, seria preciso pegar, o que nem é necessário dizer,

\footnotetext{
${ }^{19}$ Nele, o nome de Malebranche não aparece. O paralelismo é apresentado como algo que concerne às filosofias de Espinosa e Leibniz, os quais são citados de modo que suas doutrinas quase se igualariam, o que não é difícil de compreender uma vez que, lá, trata-se de mostrar o fracasso da metafísica moderna como consequência natural da projeção dos procedimentos da prática para a contemplação. Outros dois fracassos completam o quadro dos momentos em que a duração poderia ter sido tomada como realidade, como mostraremos no segundo capítulo desta tese.

${ }^{20}$ Na primeira, ele faz uma retomada da passagem da ciência antiga para a moderna, e, por conseguinte, do paralelismo antigo para o moderno.

${ }^{21}$ Bergson chega a se desculpar, na explicação da filosofia de Aristóteles, por não ter utilizado os textos, o que tornaria menos árdua a tarefa de seguir a argumentação do professor, mas "isto [os] conduziria muito longe" (Annales II, p. 58), e não seria o caso, visto que, nas suas palavras, a intenção é a de mostrar as linhas gerais da evolução da tese cuja origem se está remontando.
} 
toda a segunda parte da obra de Espinosa ${ }^{22 ”}$ (Annales II, p. 114-5). A primeira proposição citada é a que se tornara famosa, justamente, por afirmar o paralelismo: “A ordem e conexão das idéias é a mesma que a ordem e a conexão das coisas. [...] Assim, o modo da extensão e a idéia desse modo são uma só e mesma coisa, mas expressa de duas maneiras” (Annales II, p. 115). A segunda parte da citação, na verdade, é extraída do escólio da proposição II, P7. Na sequência, Bergson cita a proposição II, P17, parte de seu corolário ${ }^{23}$ e da demonstração do mesmo, mostrando o que é, no seu entender, a teoria espinosana da memória. Vamos reproduzir aqui, no corpo do texto, apenas a demonstração do corolário, pois ela traz algo que necessita ser destacado: é apresentada de modo, digamos, bastante cartesiano, e será tomada como fator de influência nas concepções materialistas do século XVIII, vistas e expostas como herdeiras do cartesianismo, estando, no fundo, mais associadas ao espinosismo. Ela é citada da seguinte maneira:

Os corpos exteriores, influenciando as partes fluidas do corpo humano de maneira que elas toquem, frequentemente, as partes moles, modificam as superfícies das partes moles, de onde resulta que, se os elementos fluidos [elementos fuidos é o que Descartes chamou de espíritos animais], se refletindo de modo diverso que antes, em seguida, tocarem as mesmas superficies com um movimento, desta vez, espontâneo, elas se refletem da mesma maneira que quando foram impulsionadas contra as superfícies pelos corpos exteriores e, por consequência, a alma contemplará de novo os corpos exteriores como presentes (Annales II, p. 115; grifo meu).

Tal é, para Bergson, o esquema ou quadro de qualquer explicação psicofisiológica da memória e da percepção. Com Espinosa, todas as doutrinas possíveis da memória poderiam ser reduzidas à forma mais abstrata e geral: supõe-se que os fluidos (os "espíritos animais”, como dizia Descartes, ou os "fuidos nervosos", como se diz atualmente) afetem as superfícies, modificando-as, e que as modificações permanecem. A qualquer época, independentemente do estado da ciência, bem como das variações sofridas pelas teorias por causa dele, a fórmula espinosista convirá, pois, nas palavras de Bergson, sempre se poderá afirmar isto: "uma superfície, uma parte fluida, uma modificação da superfície e, depois, a propósito, diz Espinosa, de uma nova reflexão dos espíritos animais sobre essa superfície, há renovação da percepção primitiva em virtude do paralelismo entre

\footnotetext{
${ }^{22}$ Está, certamente, se referindo ao segundo livro da Ética.

${ }^{23}$ Proposição II, P17: "Se o corpo humano é afetado de uma modificação que exprime a natureza do corpo exterior, a alma humana contemplará esse mesmo corpo exterior como existindo em ato ou como presente a ela”. Corolário de II, P17: “A alma poderá contemplar como se estivessem presentes os corpos exteriores pelos quais o corpo humano foi uma vez afetado ainda que não existam ou não estejam mais presentes”.
} 
o modo do pensamento e o modo da extensão” (Annales II, p. 116; grifos meus ${ }^{24}$ ). Trata-se “de uma espécie de quintessência da doutrina que foi expressa”.

Na proposição II, $\mathrm{P} 18^{25}$, por sua vez, podemos encontrar, de acordo com Bergson, a teoria da associação de idéias, uma vez que, nela, os estados de consciência e as lembranças são considerados externamente uns aos outros, se unindo ou se concatenando apenas em virtude da junção ou da concatenação dos fenômenos cerebrais correspondentes. Vimos que o que caracteriza a associação de ideias, para o autor do Ensaio, é justamente a projeção da causalidade e encadeamento dos fatos materiais para o plano da consciência, e que esse tipo de causalidade (referência para o associacionismo e para o epifenomenismo) se liga à tese do mecanicismo. Paralelismo e mecanicismo estão na origem das teorias psicológicas ou psicofisilógicas da memória ${ }^{26}$. Ambos são tanto oriundos

${ }^{24}$ Sobre a discussão quanto à pertinência (ou não) de uma leitura paralelista da obra de Espinosa, discorreremos no terceiro capítulo e no apêndice desta tese. Quanto aos “espíritos animais”, sabemos que no prefácio da Parte V da Ética, Espinosa expressa não entender como um filósofo, que se pautava pela clareza e distinção, pôde afirmar algo tão pouco claro e distinto como a existência desses espíritos, ou de uma porção de alma ligada a uma partezinha de matéria. A suposição cartesiana de que os traços dos objetos exteriores se imprimem na glândula pineal, fazendo com que ela imprima, nos espíritos animais, movimentos que não dependiam dela, fundamenta a fisiologia do automatismo corporal. Espinosa critica a teoria cartesiana por sua obscuridade em relação à união substancial e porque a fisiologia cartesiana impossibilita a tese de que a decisão voluntária possa alterar o comportamento físico-fisiológico da glândula pineal. É a concepção de liberdade cartesiana que está em foco. No Prefácio da Parte V, lemos que: “Tal é o parecer desse homem ilustríssimo (tanto quanto posso conjeturar por suas próprias palavras), parecer que eu dificilmente acreditaria proviesse de um homem tão ilustre, se ele fosse menos agudo. E, certamente, não posso me espantar o bastante ao ver um filósofo que, depois de haver firmemente decidido nada deduzir senão de princípios conhecidos por si mesmos (per se notis) e de nada afirmar senão o que percebe clara e distintamente, e depois de ter frequentemente repreendido os Escolásticos por terem querido explicar as coisas obscuras por qualidades ocultas, adotar uma hipótese mais oculta que todas as qualidades ocultas. Que entende ele, por favor, por união da mente e do corpo? Que conceito claro e distinto, pergunto, tem ele de um pensamento estreitissimamente unido a uma parcelazinha da quantidade? Eu bem gostaria que ele tivesse explicado essa união por sua causa próxima. Mas ele havia concebido a mente de tal maneira distinta do corpo que não pôde atribuir nenhuma causa singular nem a essa união, nem à própria mente, mas precisou recorrer à causa do universo inteiro, isto é, Deus [...]. Gostaria muito de saber, ainda, qual quantidade de movimento pode a mente transmitir a essa glândula pineal e com que força pode mantê-la suspensa? Pois não sei se essa glândula é revolvida mais lentamente ou mais rapidamente pela mente do que pelos espíritos animais, nem se os movimentos das paixões, que nós vinculamos estreitamente a juízos firmes, não podem voltar a se desvincular desses juízos por causas corpóreas. Disso se seguiria que, embora a mente tivesse firmemente decidido ir contra os perigos, e tivesse juntado a essa decisão um movimento de audácia, à vista do perigo, entretanto, a glândula estaria suspensa de maneira tal que a mente não poderia pensar senão na fuga. E como, certamente, não há qualquer relação entre a vontade e o movimento, tampouco existe qualquer comparação entre a potência ou a força da mente e a do corpo. E, consequentemente, as forças do corpo nunca podem ser determinadas pelas forças da mente. Acrescente-se a isso que essa glândula tampouco está situada no meio do cérebro, de maneira tal que possa ser revolvida tão facilmente, nem de tantas maneiras, e que nem todos os nervos se prolongam até a cavidade do cérebro. [...] Por último, omito tudo o que Descartes afirma sobre a vontade e a sua liberdade, pois demonstrei sobejamente que isso é falso" - está se referindo justamente às proposições finais da Parte II (e à proposição 2 da Parte III). Cf. o prefácio da Parte V da Ética (utilizamos a tradução do Grupo de Estudos Espinosanos da Universidade de São Paulo). Sobre a relação entre a mente e o corpo, e também sobre a liberdade espinosana, trataremos também no terceiro capítulo desta tese.

${ }^{25}$ Ela é citada em parte apenas. O restante foi completado pelo revisor das aulas para a publicação. Assim, lemos que: "Por aqui, concebemos claramente [o que é a Memória. O que não é outra coisa, em efeito, que um certo encadeamento de ideias que envolvem a natureza das coisas que são exteriores ao Corpo humano, encadeamento que se faz no Espírito seguindo a ordem e o encadeamento das afeç̧ões] do corpo humano” (Annales II, p. 117).

${ }^{26}$ Em "A alma e o corpo", podemos ver sintética e enfaticamente as consequências do mecanicismo para as teorias da alma e, consequentemente, para a liberdade: “As descobertas que seguiram ao Renascimento - principalmente as de 
da filosofia antiga, quanto radicalmente novos na filosofia moderna. Bergson vê a filosofia de Espinosa como aquela que melhor reuniu o antigo com o novo, dando-lhes uma resolução final de tal modo refinada que permaneceu como esquema geral para várias abordagens empíricas posteriores, sendo muito difícil combatê-la. Se Descartes separou as substâncias, o que estaria na origem do paralelismo moderno, Espinosa teria partido dessa separação e dado a ela um rigor absoluto por meio de outra invenção do próprio Descartes: a geometria analítica. O paralelismo espinosano poderia ser explicado, portanto, por analogia à geometria analítica, como uma série de figuras representadas geometricamente que corresponderiam a uma série de equações algébricas, cada equação exprimindo o que se passa na figura, sem que haja influência recíproca entre elas. Mas, essa correspondência seria uma espécie de desenvolvimento em duas linguagens diferentes de uma mesma unidade $^{27}$, ou seja, ao fim e ao cabo, a unidade é o ponto de partida e de chegada para os filósofos antigos e modernos, é ela que permanece, de um modo ou de outro, em toda a história da filosofia. E ela ganha uma versão mais acabada com o monismo espinosano que é, no final das contas, o substrato do paralelismo e do mecanicismo. De acordo com Bergson, em Espinosa, nós vemos...

... como essa doutrina do paralelismo psicofísico, quando é absolutamente rigorosa, quando vai até o fim de si mesma, está necessariamente ligada a alguma hipótese metafísica sobre a natureza do grande Todo e a uma hipótese de mesma natureza, no fundo, que a dos Alexandrinos, pois Espinosa está muito mais próximo dos Alexandrinos e mesmo de Aristóteles do que se imagina. Quando Espinosa nos dá a razão de ser do paralelismo, nós percebemos muito bem que é uma consequência necessária da própria concepção do Todo, ou seja, de Deus, da substância - simplesmente como nos Alexandrinos, absolutamente como no próprio Aristóteles. Os Alexandrinos nos diziam: inteligência, inteligíveis e todas as multiplicidades que encontramos no domínio inteligível, tudo isto é expressão, sob uma forma diferente, da unidade divida. Espinosa nos diz mais ou menos a mesma coisa, mas ele o diz sob uma forma infinitamente mais precisa porque entre os Alexandrinos e Espinosa houve Descartes e Descartes forneceu esquemas, explicações muito mais precisas e mais matemáticas (Annales II, p. 118).

Kepler e de Galileu - revelaram a possibilidade de reduzir os problemas astronômicos e físicos a problemas de mecânica. Donde, a idéia de se representar a totalidade do universo material, inorganizado e organizado, como uma imensa máquina, submetida a leis matemáticas. Desde então, os corpos vivos, em geral, e o corpo do homem, em particular, deveriam se engrenar na máquina como tantas roldanas num mecanismo de relojoaria; nenhum de nós poderia fazer algo que não estivesse antecipadamente determinado ou fosse calculado matematicamente. A alma humana se tornava assim incapaz de criar; era preciso, se ela existisse, que seus estados sucessivos se limitassem a traduzir em linguagem do pensamento e do sentimento as mesmas coisas que seu corpo exprimia em extensão e movimento" (E.S., p. 40; grifo nosso).

${ }^{27}$ Utilizando o exemplo de um círculo, equações (linguagem algébrica) e figuras (linguagem geométrica) expressariam em duas línguagens a mesma unidade, que nada mais é do que a essência da circunferência. 
O paralelismo espinosista seria a transposição do paralelismo dos antigos, deslocando-o da esfera dos inteligíveis para a das coisas (corpos e almas), por meio de uma representação muito mais clara e precisa, graças aos esquemas tomados da filosofia e da matemática de Descartes. Esta compreensão da filosofia de Espinosa faz com que Bergson afirme uma tendência irresistível dos filósofos modernos na direção do espinosismo, de modo que vemos o paralelismo espinosista ser elevado a um nível paradigmático:

Nunca, portanto, a doutrina do paralelismo entre o modo do pensamento e o modo da extensão, a consciência e o movimento, fui formulada com mais rigor ou de maneira mais satisfatória ao espírito, o que prova, aliás, que a concepção da harmonia preestabelecida de Leibniz, o ocasionalismo de Malebranche, tudo isso seja arrastado em direção a Espinosa como por uma inclinação irresistível; desde que tais hipóteses se tornam coerentes, elas se tornam espinosistas. Isto é muito evidente em Leibniz porque, em Leibniz, a doutrina evoluiu. À medida que evoluía, ela se tornava cada vez mais análoga, para não dizer idêntica ao espinosismo (Annales II, p. 121).

O acordo das mônadas exprimiria uma mesma coisa (a harmonia preestabelecida), pois seria o acordo existente entre todas as visões dela, tomadas de pontos de vista diferentes, e que, caso pudessem ser adicionadas (não podem, pois são infinitas), reproduziriam o próprio Deus. Isto é o que fora dito por Espinosa, no entender de Bergson, com mais rigor, pois ele o disse em uma linguagem matemática. Quanto a Malebranche, não haveria exatamente a “mesma evolução”, tal qual em Leibniz, e ele faria um esforço constante para não se tornar espinosista. Esforço difícil (e inútil), porque o seu "ocasionalismo esta[ria] muito perto de tomar a forma do paralelismo espinosista”, pois, mesmo que Deus intervenha, em cada caso particular, para colocar uma espécie de acordo entre a alma e o corpo, ele estabeleceu leis absolutamente fixas, de maneira que "tudo se passa como se a correspondência tivesse sido estabelecida de uma vez por todas”, tal como na harmonia préestabelecida, a qual, sob o olhar bergsoniano, poderia ser equiparada à doutrina espinosista. O mesmo vale para Descartes. Bergson faz, então, uma inversão rara em sua obra publicada: coloca Descartes na rota do espinosismo. Ele teria expresso um certo ocasionalismo ${ }^{28}$, que se manifestaria pelo fato de que a alma escolheria uma ocasião para intervir, fazendo surgir nela algo que estaria em

\footnotetext{
28 "Descartes, toda vez que se exprimiu em termos claros, se exprimiu, para nós, nos mesmos termos que Malebranche” (Annales II, p. 122). O ocasionalismo cartesiano diferiria do de Malebranche por não se tratar de uma ocasião que Deus aproveitaria para intervir no mundo, mas da qual a própria alma se aproveitaria.
} 
relação com o que ocorre no corpo. Assim, Descartes estaria "no caminho do ocasionalismo, o ocasionalismo no caminho da harmonia pré-estabelecida, a harmonia pré-estabelecida no caminho do espinosismo” (Annales II, p. 123). Não nos parece estranho, portanto, que, em A evolução criadora, Leibniz faça “um” com Espinosa, no que se refere ao paralelismo, uma vez que a evolução de sua doutrina a torna idêntica ao espinosismo. São doutrinas tomadas como equivalentes porque, uma vez posto o espinosismo, o leibnizianismo pode ser identificado a ele. Isto mostra, do nosso ponto de vista, que, quando Bergson fala do "paralelismo de Leibniz e Espinosa” como se fosse uma única coisa, na história dos sistemas de A evolução criadora, por exemplo (ou em qualquer texto posterior ao curso), ele está se referindo, sobretudo, ao paralelismo de Espinosa, com o qual o de Leibniz acabaria por coincidir. Ou seja, no fundo, ele tem principalmente Espinosa em mente, no que se refere a esse tema.

Podemos dizer, então, que a doutrina espinosista é posta por Bergson como a origem metafísica da psicofisiologia contemporânea. A explicação do paralelismo moderno, no curso sobre a história das teorias da memória, restringe-se à filosofia de Espinosa, como dissemos, sendo os outros “arrastados para a sua órbita”. Desse modo, mesmo que na aula seguinte (a última), sejam feitas relações entre os outros filósofos mencionados (Descartes, Leibniz e Malebranche) e os intermediários responsáveis pela introdução dessa doutrina metafísica na psicofisiologia, está posto que, no fundo, todos poderiam ser reduzidos ou reconduzidos ao espinosismo.

A passagem do século XVII para o século XVIII é também a passagem dos racionalistas para os materialistas e, com ela, ocorre uma espécie de universalização da tese mecanicista. Com o materialismo do século XVIII, a vida mental será reduzida a um aspecto da vida material, o que não acontecia com o paralelismo dos filósofos do século XVII, porque, para eles, a alma não seria um simples reflexo (fosforescência) do corpo ou uma versão mais sutil e reduzida - a correspondência significa uma equivalência das séries. Contudo, eles teriam preparado, para Bergson, "as vias a um cartesianismo diminuído e estreito”, de acordo com o qual a alma se reduziria a um conjunto de fenômenos cerebrais, “aos quais a consciência se acrescentaria como uma luz fosforescente” (E.S., p. 40). Enquanto Descartes, mesmo sendo o verdadeiro criador do paralelismo, não tira todas as consequências da distinção fundamental entre pensamento e extensão, deixando uma abertura aos fatos que atestam a influência de um sobre o outro $^{29}$, seus sucessores enfatizaram e aprofundaram

\footnotetext{
${ }^{29}$ Nas lições sobre “As teorias da alma”, ministradas no Liceu Henri-IV em 1894, Bergson cita algumas cartas de Descartes à Princesa Elisabeth, escritas em maio e junho de 1643, às quais também remetem os alunos do curso sobre a história das teorias da memória. Elas demonstram que Descartes prefere, de certo modo, sacrificar o rigor do sistema a sacrificar a liberdade ou a influência entre corpo e alma. Assim, ele deixaria aberta a explicação sobre a relação entre corpo e alma, afirmando que não podemos, ou melhor, não devemos explicá-la. Em uma delas, Descartes deixaria
} 
uma tendência presente nele, mas não desenvolvida, em detrimento da que concedia uma abertura à liberdade humana. Por todo o século XVIII, o rastro dessa simplificação progressiva da metafísica cartesiana pode ser seguido. E mais: “à medida que se restringe, ela se infiltra de preferência em uma fisiologia que, naturalmente, nela encontra uma filosofia apropriada para lhe dar a confiança em si mesma da qual tem necessidade” (E.S., p. 40). Mesmo nos casos em que não se tinha avançado empiricamente, poder-se-ia seguir em frente porque tal mecanismo, colocado como fundamento da realidade, o permitia ${ }^{30}$. De certo modo, ela impedia a ruína da ciência, mas não impediu a ruína da própria metafísica.

Em “A alma e o corpo”, os filósofos mencionados como responsáveis pela condução da metafísica do século XVII à ciência do século XIX são: La Mettrie, Helvétius, Charles Bonnet e Cabanis. No curso, a lista de intermediários do século XVIII é quase a mesma, com uma diferença: no lugar do nome de Helvétius, encontramos o de Condillac. Eles são os representantes franceses dessa infiltração e, com eles, também são citados representantes da Inglaterra e da Alemanha. Em todo caso, Bergson faz questão de dizer que o mesmo progresso se cumpriu de maneira análoga nos países aludidos, haja vista a comunicação constante entre seus filósofos e cientistas.

O materialismo pode ser visto, de fato, como um cartesianismo duplamente reduzido, pois é um estreitamento do paralelismo que, por sua vez, já era uma limitação da concepção de Descartes. Ora, na última aula do curso sobre a história das teorias da memória, podemos seguir, principalmente, o rastro do espinosismo na simplificação operada pelos materialistas na metafísica cartesiana. Em Condillac, se encontraria tanto um paralelismo, quanto o seu desdobramento num associacionismo, já que ele teve a ideia "de uma reconstituição integral da alma humana com elementos simples” (Annales II, p. 128) - o que faz dele um dos ancestrais do que pode ser chamado de psico-associacionismo. Em Bonnet, estaria presente a teoria do paralelismo psicofisiológico e também a teoria da memória sustentada por Espinosa. Trata-se da teoria cartesiana dos espíritos animais na versão espinosana, uma vez que as próprias palavras de Bonnet ${ }^{31}$ coincidiriam “exatamente com o que dizia Espinosa; são quase as mesmas palavras” (Annales II, p. 130). De

claro inclusive que (nas palavras do filósofo evocadas pelo professor): "para saber o que é a união da alma com o corpo, é preciso viver, e se abster de pensar” (Cf. Cours III, p. 224).

30 “... era natural que o cientista aceitasse, das mãos da antiga metafísica, a doutrina pronta, construída com todas as peças, que se adaptava melhor à regra de método que ele achara vantajoso seguir. Ele não tinha, aliás, outra escolha. A única hipótese precisa que a metafísica dos últimos três séculos nos legou a esse respeito é justamente a de um paralelismo rigoroso entre a alma e o corpo" (E.S., p. 39).

${ }^{31}$ Bergson cita uma parte das Méditations sur l'origine des sensations et sur l'union de l'âme et du corps, a saber: "Um fluido não é feito para ser a cede física de impressões duráveis. Não é, portanto, o fluido nervoso que conserva, durante meses ou anos, a lembrança dos objetos. Ela deve se ater [a lembraça] às partes sólidas do órgão do pensamento. O objeto impresso dá a certas partes desse órgão determinações favoráveis em virtude das quais ele 
acordo com esse "filósofo naturalista", os objetos imprimiriam, no órgão do pensamento, determinações que possibilitariam a conservação das lembranças ou imagens dos mesmos. Mas, ele não teria especificado o que seriam tais “determinações” ${ }^{32}$, fornecendo apenas, assim como fora afirmado sobre Espinosa, um esquema para a explicação ou a construção de uma teoria da memória. Com Bonnet, ficam claras as origens da psicofisiologia, ou seja, fica evidente que suas origens não se encontram na experiência, pois as fibras (ou feixes de fibras em questão nas determinações do cérebro ou conservação das lembranças) permanecem desconhecidas. Mas, para além da presença espinosista em Bonnet ou da manutenção de um esquema vazio neste naturalista, que não se ligaria efetivamente à escola materialista ${ }^{33}$, Bergson chama a atenção para o fato de que, mesmo quando a anatomia do cérebro passa a ser mais conhecida (com a histologia, ciência que data do século XIX), o esquema de Bonnet será mantido, mudando apenas a terminologia: de fibras, passa-se a falar em células e, depois, em neurônios. O que é algo grave para a ciência, significando que...

Estamos aqui em presença de um caso talvez único na história da ciência fisiológica: o progresso da anatomia não influenciando em nada a fisiologia das funções, constituída sem que se parta da anatomia dos órgãos. Que o progresso da fisiologia de uma função seja paralelo ao progresso da anatomia do órgão, ou dele dependa ao menos em certa medida, isto é natural, é necessário. Só podemos aprofundar o mecanismo de funcionamento de uma máquina, se conhecermos a estrutura e as peças. Bem, quanto à questão que nos ocupa, não é assim que as coisas se passam, e a fisiologia da função, constituída antes da anatomia do órgão, não muda com o conhecimento da anatomia do órgão - absolutamente nada muda no conhecimento da fisiologia completamente íntima da função (Annales II, p. 133).

Isto prova que a psicofisiologia foi construída a priori, sendo, na verdade, uma teoria metafísica, ou melhor, sendo uma das versões da teoria que, em épocas diferentes, “desce para se colocar sobre os dados científicos realmente experimentais que se possua” (Annales II, p. 134).

conserva e reterá a lembrança ou a imagem do objeto” (Annales II, p. 130).

${ }^{32}$ Bergson cita passagens do tratado de Bonnet intitulado Contemplation de la nature: “As fibras sensíveis do cérebro foram construídas a partir de relações estabelecidas com a maneira de agir dos objetos, tais que eles produziram [no cérebro] determinações mais ou menos favoráveis, que constituem o processo da memória e da imaginação”; "Ignoramos em que consistem essas determinações porque o mecanismo das fibras sensíveis nos é desconhecido". E também uma parte do Essai analytique sur les facultés de l'âme, qual seja; "Importa muito que eu faça observar a meu leitor que, falando tão frequentemente de fibras, não pretendo em nada determinar a espécie de instrumento ao qual a produção e a reprodução de ideias está atado, faço profissão de ignorar perfeitamente a natureza dos órgãos infinitamente pequenos. Declaro, portanto, muito expressamente, que eu emprego as palavras fibras e feixes de fibras para exprimir um efeito cuja causa ou o 'como' nos é desconhecida” (Annales II, p. 132).

${ }^{33}$ Segundo o professor, Charles Bonnet seria tanto ou mais conhecido como naturalista do que como filósofo, e não se ligaria à escola materialista porque, para ele, ainda que as faculdades da alma estejam ligadas à matéria, isto não provaria a materialidade da alma - ele mantém a distinção dos domínios, não reduzindo um inteiramente ao outro. 
Bonnet, contudo, teria consciência das origens metafísicas de sua doutrina, não negando seus laços de parentesco ${ }^{34}$. Quanto ao materialista seguinte, na ordem de exposição do curso, La Mettrie, os “espíritos animais” seriam assumidos como um fato de experiência ${ }^{35}$, de modo que, "pouco a pouco, essa doutrina, constituída a priori, toma as aparências de uma doutrina de origem experimental” (Annales II, p. 137). Contribuíra, para propagar essa crença, o fato de La Mettrie ser médico, o que difundia uma ilusão de que sua doutrina estava ligada a observações médicas. No entender de Bergson, ele seria muito mais um "metafísico da escola de Descartes", vinculado ao cartesianismo estreito que ajudara a manter e propagar, o qual não é senão o espinosismo. De acordo com o professor, "é preciso lembrar que ele tinha feito seus estudos medicais em Leyde, sob a direção de Boerhaave, que é mais conhecido por suas opiniões espinosistas. Foram reveladas, aliás, no próprio La Mettrie, passagens estritamente espinosistas” (Annales II, p. 138). Para finalizar a exposição dos materialistas franceses do século XVIII, Bergson menciona o também médico e filósofo Cabanis, cuja influência predominara sobre os que se ocuparam das relações entre o físico e o moral, na primeira metade do século XIX, tanto na França como em outros países ${ }^{36}$. Em seu tratado ou conjunto de memórias intitulado Rapports du physique et du moral, Cabanis teria colocado a doutrina do paralelismo psicofísico em um lugar de destaque, subsumindo-a a Descartes, filósofo por quem declarara sua admiração. Ao citar um trecho curto desse livro, Bergson o corrige, fazendo a diferenciação entre Descartes e os cartesianos e colocando Espinosa, no fundo, como a verdadeira fonte Cabanis:

Há, na primeira memória, a frase segundo a qual 'Descartes forneceu, à ciência fisiológica, serviços imortais porque [cito textualmente suas palavras] descobriu no cérebro todo o segredo do mecanismo do pensamento'. Não, Descartes não foi tão longe, mas nós vemos como essa doutrina se liga ao cartesianismo e, no fundo, ao espinosismo mais ainda que ao cartesianismo (Annales II, p. 140).

Todos esses filósofos materialistas são ideólogos porque se valem do método ideológico, o qual, na explicação do curso, consiste em aplicar a simplicidade e a clareza de modo que, com

\footnotetext{
${ }^{34}$ Em um texto intitulado "Vue du leibnizianisme", Bonnet declara seu reconhecimento face à filosofia de Leibniz, chegando a aconselhar a sua leitura aos jovens estudantes de filosofia. Bergson menciona tal fato, mas em nenhum momento da explicação da teoria de Bonnet fora feita uma relação entre ambos (Bonnet e Leibniz), o que se explicitou foi a semelhança entre as suas palavras e as de Espinosa.

${ }^{35}$ Bergson cita um longo trecho da Histoire naturelle de l'âme (1745), que finaliza com a seguinte declaração: "Podemos concluir, de tudo o que foi dito sobre a memória, que ela é uma faculdade da alma que consiste nas modificações permanentes do movimento dos espíritos animais” (Annales II, p. 137).

${ }^{36}$ A filosofia de Schopenhauer é mencionada como exemplo da influência de Cabanis.
} 
elementos simples, se creia tudo reconstituir. Finalizando a lista dos ideólogos, estaria Taine, psicólogo do século XIX, “o último dos ideólogos”. Sabemos que Taine é um dos principais interlocutores de Bergson no que diz respeito ao determinismo psicológico, desde o Ensaio. No curso, a sua ligação com Espinosa é enfaticamente declarada:

Nesse sentido, ele se associa aos ideólogos. Há uma tal afinidade entre esses ideólogos e Espinosa que Taine se associa também a Espinosa. Ele tinha começado por uma fase espinosista e as teorias, como diria eu, as ideias de origem espinosista são numerosas em Taine. Poderíamos dizer que toda sua teoria, em um certo sentido, é de inspiração espinosista. A ideia de uma faculdade mestra, uma espécie de ideia simples da qual, em seguida, se poderia deduzir, como por assim dizer matematicamente, toda a obra de um artista ou de um literato, é algo essencialmente espinosista (Annales II, p. 141).

No Ensaio sobre os dados imediatos da memória, Hyppolite Taine e Stuart Mill são diretamente visados por Bergson na crítica ao determinismo associacionista, cuja doutrina distingue os fatos psíquicos coexistentes, de modo que a ação livre estaria vinculada a uma representação do eu como um conjunto de estados psíquicos em que o mais forte exerce uma influência sobre os demais. Ora, os adversários do determinismo acabam por segui-lo, uma vez que falam de associações de idéias e conflitos de motivos. Nas palavras do Ensaio, "O erro do associacionismo é ter eliminado, a princípio, o elemento qualitativo do ato a se realizar, para dele conservar apenas o que há de geométrico e impessoal: à idéia desse ato, assim, descolorida, foi preciso associar, então, alguma diferença específica, para distingui-la de muitas outras. Mas, essa associação é obra do filósofo associacionista que estuda meu espírito, e não de meu próprio espírito” (E., p. 121). Nesse momento, os associacionistas e seus adversários são abordados do contexto da discussão sobre a liberdade (terceiro capítulo do livro), à qual voltaremos no final deste capítulo, por meio das análises empreendidas, no capítulo anterior, quanto à distinção entre uma multiplicidade de justaposição dos estados de consciência e uma multiplicidade de fusão ou penetração mútua, originalmente defendida por Bergson. Ora, tratava-se, como dissemos anteriormente ${ }^{37}$, de uma abordagem da psicologia cujo foco era mais propriamente metafísico, revelando os filósofos que forneceram ocasião para os erros dos psicólogos, por exemplo, sendo Kant, e não Espinosa, o principal deles. Isto significa que a crítica ao criticismo, como fonte do determinismo e do "problema da liberdade", permanece como um dos temas e resultados maiores do Ensaio, e que o fato de Bergson vincular Taine a Espinosa de

\footnotetext{
${ }^{37}$ Cf. nota 2 deste capítulo.
} 
modo tão contundente, no curso, não apaga outros vínculos e heranças ${ }^{38}$, mas pode, pensamos, lançar outra luz sobre esses mesmos temas. De todo modo, não cabe aqui uma revisão dessa temática, e sim a reconstituição da importância do paralelismo na obra bergsoniana “como um todo”. Portanto, devemos finalizar a apresentação do curso e seguir a tarefa de (re)construção da mencionada crítica e sua evolução.

Na sequência do curso, Bergson se volta brevemente para a filosofia inglesa, e menciona o médico filósofo que teria exercido um papel análogo ao de Bonnet, David Hartley, o qual fora considerado como inspirado por Newton. Isto se deve ao fato de que ele falara em "vibrações” dos nervos no cérebro, tomando tal palavra do vocabulário físico, mas bastaria, "lançar um olhar sobre a sua principal obra para se convencer de que a sua doutrina é de inspiração cartesiana e espinosista” (Annales II, p. 143). Após Hartley, Bergson menciona aquele ao qual todos os fisiologistas recorrem quando tratam da memória: Alexander Bain. Este teria exercido o papel de Taine na Inglaterra, e sua doutrina também seria constituída sem os fatos, o que faz dela uma continuação da escola cartesiana. Taine e Bain são considerados as grandes referências para a fisiologia contemporânea. Na Alemanha, destaca-se os dois tratados de Wolf, nos quais o paralelismo pode ser encontrado, mesmo que não seja aceito sem restrições. Neste caso, a relação mais explícita seria com a doutrina leibniziana da harmonia pré-estabelecida ${ }^{39}$. Donde se segue a conclusão de que se pode facilmente encontrar a doutrina paralelista, sob uma ou outra apresentação, na maior parte dos trabalhos de sua época. Bastaria substituir a terminologia, como já apontamos, para que se tenha o cartesianismo ou “o que dizia incompletamente Descartes, o que disse mais completamente Malebranche, porém, de uma maneira geral, a doutrina do paralelismo que temos em Espinosa” (Annales II, p. 142-3).

Podemos afirmar que a história das teorias da memória feita por Bergson não revela uma idéia nem de progresso propriamente, já que se trata mais, nas suas palavras, da transição de uma concepção a outra ${ }^{40}$, nem de descontinuidade ou dispersão temporais. A história das concepções

\footnotetext{
${ }^{38}$ Outro filósofo considerado como fonte do associacionismo é o inglês David Hume, para o qual a associação, vista como uma lei geral que comanda a vida psicológica e seus encadeamentos, deveria ser no domínio psíquico o que a atração newtoniana era no físico.

39 Segundo Vittorio Morfino, no texto "O primado da conexão sobre a série”, “a interpretação do soi-disant paralelismo espinosista por Christian Wolff" liga-se à "tentativa de escapar do odium theologicum de l'époque", de modo que "ele se esforça por colocar em evidência as diferenças que separam a filosofia de Leibniz da de Espinosa", o que o tornaria mais afeito à corrente leibniziana, na perspectiva de Bergson. Voltaremos ao texto de Morfino no terceiro capítulo, quando tratarmos da obra espinosana. A esse respeito, conferir também o livro de Sylvain Zac, Spinoza en Allemange: Mendelssohn, Lessing et Jacobi, ao qual também voltaremos no último capítulo desta tese.

${ }^{40}$ No final da última aula, após mostrar a permanência da tese do paralelismo nas filosofias do século XVIII e na ciência contemporânea, Bergson declara o seguinte: "Eis, senhores, o progresso das nossas ideias, ou melhor, a transição de uma forma de doutrina a outra, pois podemos duvidar que tenha havido progresso” (Annales II, p. 143).
} 
filosóficas, a partir do ponto de vista de uma evolução, tal como afirmada por Bergson ${ }^{41}$, não se separa da duração, que é constituída essencialmente tanto pela continuidade, quanto pela heterogeneidade. Isto nos permite entender uma afirmação rara do filósofo, feita na primeira aula do curso sobre as teorias da memória, e que poderia parecer contraditória com a exposição levada a cabo nas aulas seguintes, pois, de acordo com ela, há uma lei geral que pode ser assim enunciada: “em um mesmo período filosófico determinado, os filósofos que seguem linhas divergentes estão menos distantes uns dos outros do que os filósofos pertencentes a diferentes épocas e que, no entanto, se associam ou crêem se associar à mesma filosofia geral e seguir a mesma direção” (Annales II, p. 42). As diferenças históricas devem, portanto, ser consideradas em um estudo que busque origens ou heranças. São, digamos, essenciais, e não acidentes de uma mesma e única história. Entendemos que o curso mostra a concepção de história em Bergson como evolução porque ao mesmo tempo em que se pode falar de uma continuidade (transição de uma mesma concepção), necessariamente se deve falar em uma heterogeneidade (novidade) de concepções. Por isso o paralelismo é antigo $e$ moderno, é reduzido ao antigo e ao mesmo tempo não pode ser comparado com o que os filósofos gregos conceberam (“os antigos nem sequer haviam pensado”). Por isso, a história dos sistemas de A evolução criadora pode situá-lo como algo incomparável.

A história das concepções filosóficas, vista como evolução da tese que nega o tempo real, é também o que possibilita a Bergson encontrar a própria duração e afirmá-la como objeto filosófico fundamental, negando a sua negação. E, se a duração é o ser das coisas (de tudo), ela não se coloca fora das condições particulares que possibilitam e constituem as ações e os pensamentos humanos, de modo que não caberia falar em uma verdade única e exterior ao mundo vivido (um mundo ideal, tantas vezes criticado por Bergson), mas ela também não se perde em uma dispersão temporal, numa identificação com múltiplas “verdades” pontuais e externas umas às outras. A duração é o ser das coisas (idéias, sentimentos, acontecimentos...), o que significa que se pode falar, na história da filosofia, tanto em um processo ou desenvolvimento temporal contínuo, quanto em uma multiplicidade heterogênea. O que não muda, não dura.

Para finalizar a crítica de Bergson ao paralelismo no que tange à compreensão da sua origem e inserção histórica, devemos mencionar o artigo em que a última palavra é dada a esse respeito: “A alma e o corpo”. Este texto foi pronunciado, na seção do dia 28 de abril de 1912, num ciclo de

\footnotetext{
41 “É [a concepção moderna do paralelismo] o aristotelismo que se tornou moderno, é uma transformação, mas não é uma modificação radical” (Annales II, p. 59; primeira aula); “[...] como dizíamos, isso não foi uma transformação completa, mas uma evolução” (Annales II, p. 65; segunda aula).
} 
conferências sobre Le matérialisme actuel ${ }^{42}$, e posteriormente publicado sob forma de artigo. Nele, o materialismo não aparece no centro das preocupações do filósofo. Mesmo citando-o inicialmente, ele não será de fato o verdadeiro adversário combatido. Sem sair do tema proposto, Bergson o subverterá, mostrando, justamente, que não há materialismo atual, não há atualidade do materialismo. O "materialismo atual” é substituído pela tese da qual ele depende, o paralelismo. A conferência, feita tantos anos depois do curso, volta a essa abordagem, demonstrando que a questão se mantinha aberta, apesar de tê-la tratado de modo definitivo em trabalhos anteriores, como no próprio curso, o qual, por sua especificidade, não tivera apelo público, e em seu terceiro livro publicado, A evolução criadora, que tivera muita repercussão, suscitando acaloradas discussões e posicionamentos, quanto aos mais diversos temas - dedicar-nos-emos mais a ela no próximo capítulo. Mesmo tendo retomado, na história dos sistemas de A evolução, a origem última (natural) de tal tese ou dos equívocos da metafísica, novamente a inscrição propriamente histórica se põe como exigência, sendo necessário o desvelamento e a contextualização da tese materialista (epifenomenismo) na história da filosofia, pois se trata, como vimos, de uma tese de origem metafísica, e não científica. Um vez mais, pareceu necessário circunscrever o materialismo historicamente, para, de uma vez por todas, explicitar o que o sustenta, o dogma oculto nas suas pretensas posições empíricas. Dos textos que compõem a coletânea A energia espiritual (1919), “A alma e o corpo” é o mais antigo dentre os de temática propriamente filosófica, é também o último escrito sobre a problemática paralelista, encerrando-a sob o viés histórico. Bergson recolocará a questão quanto à origem da hipótese de uma equivalência entre o cerebral e o mental, e reafirmará que se trata de algo não construído, nem sustentado pela anatomia, fisiologia, estrutura das funções ou estudo das lesões do cérebro. Ele fora deduzido dos princípios gerais de uma metafísica concebida para “dar corpo às esperanças da física moderna” (E.S., p. 39). Na conferência, após recuperar a origem histórica da hipótese em questão, situada no século XVII (Leibniz e Espinosa) e aludir à mediação pela qual ela chegou à contemporaneidade (intermediários do século XVIII), Bergson é enfático ao explicitar a metafísica oculta na ciência, e desvelar no cientista um metafísico inconsciente e, consequentemente, inconfesso. Seria compreensível, nas palavras de Bergson, que o cientista filosofasse sobre a relação do físico com o psíquico pelo paralelismo, uma vez que a metafísica não fornecera outra explicação, mas é inadmissível que, ao fazê-lo, afirme e creia fazer ciência. Isto é,

\footnotetext{
${ }^{42}$ A série de conferências foi organizada por Paul Doumergue e apareceu publicada, primeiramente, na revista Foi et Vie, da qual ele era o redator-chefe, com o título Le matérialisme actuel. A intenção original do ciclo, submetida como tarefa a seus participantes, era a de mostrar como o materialismo estava em um momento de recuo.
} 
...que tal ou tal dentre eles venha nos dizer que isso é ciência, que é a experiência que nos revela um paralelismo rigoroso e completo entre a vida cerebral e a vida mental, ah não! Nós o deteremos e lhe responderemos: vocês cientistas podem sem dúvida sustentar essa tese, como o metafísico a sustenta, mas não é mais o cientista que fala em vocês, é o metafísico. Vocês nos devolvem simplesmente o que nós vos emprestamos. A doutrina que vocês nos trazem, nós a conhecemos: ela sai de nossos ateliês; somos nós, filósofos, que a fabricamos; e trata-se da uma velha, muito velha mercadoria (E.S., p. 41).

Nessa conferência, Bergson menciona explicitamente apenas a origem moderna do paralelismo, tal como em A evolução criadora. Contudo, pensamos que a "velha mercadoria" evocada é tanto moderna quanto antiga, ou seja, ainda que o texto só faça referência à tese legada pela metafísica nos últimos séculos, o que já configura uma "velha mercadoria", podemos ver também aqui uma alusão à origem antiga da tese. Isto, inclusive, estaria mais de acordo com o espírito do quarto capítulo de $A$ evolução, que acaba por afirmar o caráter antigo - grego - da metafísica. O quarto capítulo do livro retoma também as origens históricas da tese do paralelismo, mas o faz com outra intenção: demonstra o refinamento a que a inteligência, por meio de sua capacidade simbólica, pode chegar. E, para tanto, o foco será posto na comparação entre a ciência antiga e a moderna. Se o paralelismo de Espinosa e Leibniz não é remetido ao antigo, as filosofias desses pensadores, como um todo, o são, e a de Espinosa será definida como um "aristotelismo moderno”. Assim, de um modo ou de outro, o livro coloca as fontes antigas das teses modernas, e pensamos que o artigo de 1912, “A alma e o corpo”, não explicita a mesma conclusão, mas não foge a ela.

Ao finalizar a curta curva genealógica do artigo, a qual acabamos de brevemente descrever, Bergson volta, de certa maneira, a algo que estava em seu primeiro livro. Com outras palavras em relação ao que fora dito no Ensaio, e tendo passado por toda a reconstituição histórica, que lá não estava presente como preocupação (no que tange ao paralelismo), o que vemos reiterada é a postura fundamental, anterior e subjacente à busca, qual seja: a distinção entre uma tese metafísica historicamente determinada e a abordagem empírica da ciência. Assim, se essa tese metafísica...

não vale menos, seguramente; mas ela não é também a melhor. Tomem-na pelo que ela é, e não a façam passar por um resultado da ciência, por uma teoria modelada sobre os fatos e capaz de se remodelar sobre eles, uma doutrina que pôde tomar, antes mesmo da eclosão de nossa fisiologia e de nossa psicologia, a forma perfeita e definitiva pela qual se reconhece uma 
construção metafísica (E.S., p. 41).

Por um lado, é reafirmada a validade da tese metafísica do paralelismo no seu momento histórico - ela "não vale menos" - e recolocada a importância da distinção entre essa tese, de outro momento histórico, e os fatos novos da ciência, que, ao invés de se submeterem a ela, deveriam servir para rejeitá-la como explicação da realidade psicológica e psicofisiológica na contemporaneidade. Por outro lado, ela é questionada propriamente como tese metafísica, ou seja, se “não vale menos”, “também não é a melhor”, o que se insere no contexto da crítica de Bergson à tendência aprofundada no cartesianismo - a mais fácil - em detrimento da que se abriria para a liberdade, e também situa o filósofo no debate, uma vez que, como exposto um pouco adiante no texto, enquanto “cientistas de uma competência indiscutível” começam, ou começaram a pouco, a se posicionar contra essa tese, tal enfrentamento estivera presente nas suas preocupações há pelo menos vinte anos - quando dissera que "a doutrina, até então considerada como inatingível, tinha, ao menos em parte, necessidade de um remanejamento” (E.S., p. 51). Para ver como a crítica se coloca no nível dos fatos, precisamos nos reportar a Matéria e memória, um ensaio sobre a relação da alma com o corpo que (re)põe a crítica ao paralelismo, sob outra perspectiva, tal como veremos agora.

\section{Abordagem empírica}

Antes mesmo da assimilação da psicologia atual ao paralelismo dos filósofos modernos, Matéria e memória (1896) buscara o que “a experiência diz”, ou seja, o que o estudo dos fatos empíricos demonstra. Nessa segunda obra publicada pelo filósofo, o problema da ação recíproca do corpo e do espírito, encontrado no Ensaio, será retomado e discutido com a elaboração de uma concepção nova da relação psicofisiológica. No primeiro livro, a crítica ao determinismo levara à descoberta da autonomia do espírito e colocara a liberdade como um fato, fazendo necessário um estudo que tratasse da relação psicofisiológica e do papel do corpo nessa relação, mantendo o resultado alcançado no estudo anterior. Mas, se o problema dessa relação foi encontrado no Ensaio, isto se deve à discussão impetrada contra o determinismo ${ }^{43}$, e não contra o paralelismo filosófico. No

\footnotetext{
43 Apoiando-se no determinismo como método de conhecimento, cujo alcance está na redução de tudo o que não é constituído por articulações mecânicas como se o fosse (método que é o correspondente da tese ontológica que afirma o mecanicismo universal, ou seja, que concebe a realidade como um todo capaz de ser explicado por um mecanismo matemático), psicólogos, fisiólogos ou psicofisiologistas, que lidam com fatos, acabam “postulando” uma solução, $a$ priori, metafísica, quando acreditam partir da experiência ou se restringir aos dados empíricos. "Mas, a qualquer
} 
momento em que o livro foi publicado (1896), Bergson ainda assimilava o epifenomenismo à ciência, de maneira que deveria, sobretudo, ser refutado nesse terreno, numa abordagem também empírica. Mais tarde, como vimos, ele é remetido à tese do paralelismo, como sua versão “atual e empobrecida" ${ }^{44}$. Parte do livro é diretamente consagrada à determinação da relação entre o estado psicológico e seu concomitante cerebral (capítulos dois e três), por meio do estudo de casos normais e patológicos dos quais os cientistas (fisiologistas, psicólogos ou psicofisiologistas) lançam mão para provar a concepção das localizações cerebrais. Mas, se não há, nesse livro, uma tentativa de “demonstrar a tese negativa 'não há paralelismo'”, como Bergson o afirma em uma discussão na Société de Philosophie, anos depois (1901), uma vez que “de uma tese negativa não teríamos muito a tirar", e sim uma tentativa de "formular uma tese positiva, suscetível de melhoramento e de verificação progressiva” (M., p. 484), e que, por isso mesmo, seria para certas doutrinas metafísicas “uma passagem ao limite”, os seus resultados acabam por ser uma refutação do paralelismo, ainda que este não seja o seu ponto de partida. A verificação empírica permite a revisão de concepções psicológicas e psicofisiológicas que sustentam a localização cerebral das lembranças. E, partindo dos dados científicos, a própria metafísica é que se vê em condição de “verificação e melhoramento”. Isto também porque, no prefácio da sétima edição do livro (1911), o paralelismo é identificado ao epifenomenismo, fazendo valer para o primeiro tudo que antes fora examinado em relação ao segundo (a análise dos casos utilizados pelos deterministas). Assim, a crítica empreendida no

imagem tomada, não se demonstra, não se demonstrará nunca que o fato psicológico seja determinado necessariamente pelo movimento molecular; pois, em um movimento, encontrar-se-á a razão de um outro movimento, não a de um estado de consciência: apenas a experiência poderá estabelecer que o último acompanha o outro” (E., p. 111).

${ }^{44}$ Em diferentes ocasiões, Bergson voltará a explicitar o caráter oculto da tese metafísica do paralelismo dissimulada em concepção científica, no epifenomenismo, tal como vemos, por exemplo, em 1916, quando da apresentação de uma conferência, em Madrid, sobre “A personalidade”: “... tentei estabelecer que a tese segundo a qual a consciência é apenas uma espécie de duplicação da atividade cerebral, se limitando a iluminar os movimentos da matéria nervosa, mesmo quando ela quer se dar um ar científico, essa tese, em realidade, é somente uma hipótese metafísica, uma metafísica inconsciente de si mesma. A pior maneira de ser metafísico é sê-lo sem sabê-lo. É o que acontece com a teoria do paralelismo. É uma metafísica dissimulada em ciência. A idéia de que os estados de consciência são como fosforescências que iluminam a atividade dos fenômenos cerebrais correspondentes não foi verificada pelos fatos” (M., p. 1216; grifo nosso). Como sabemos, os textos reunidos no livro Mélanges não constam das publicações feitas durante a vida do filósofo ou com a sua permissão explícita. Bergson declarou, às pessoas amigas que cuidariam de sua obra, que nada do que não fora publicado por ele deveria vir a público após a sua morte (cartas, rascunhos e tudo o que fosse encontrado deveria ser queimado). No entanto, uma "interpretação" de suas palavras deu lugar a que se considerasse que não estaria sob a mesma interdição tudo o que alguma vez já tivesse sido exposto publicamente, ou tido permissão para tanto. São esses textos (conferências, cartas, comentários de obras...) que compõem o referido livro. Ao tomarmos os textos de A energia espiritual como as últimas palavras do filósofo sobre o paralelismo, estamos considerando a sua obra publicada em vida (essa coletânea e a seguinte, O pensamento e o movente, reúnem os artigos que o filósofo quis publicar e o fez a partir de um processo de escolha dos textos e também, certamente, de ordenação dos mesmos), ainda que façamos referência aos textos inseridos na coletânea Mélanges, a qual é extremamente valiosa para qualquer estudioso de Bergson. 
“terreno dos fatos”, em Matéria e memória, mesmo não sendo primeiramente dirigida contra o paralelismo não o coloca fora de seu alcance, mas adquire, ao contrário, um maior alcance: Bergson poderá retroativamente assimilar as duas hipóteses de modo a reforçar a crítica de uma pela outra. Esse prefácio demonstra o seu reconhecimento quanto ao peso efetivo da tese metafísica do paralelismo na ciência, declarado em trabalhos posteriores ao livro, como vimos no curso sobre a “História das teorias da memória” (1903-1904), inserido em suas linhas gerais no quarto capítulo de A Evolução criadora (1907), e cujo apogeu é a conferência sobre o materialismo atual, “A alma e o corpo” (1912), publicada como artigo - o último em que essa temática é abordada -, cujo tom é tanto provocativo quanto definitivo. Se, na perspectiva histórica, o artigo sobre “A alma e o corpo" encerra a questão do materialismo atual pela demonstração de que não havia atualidade do materialismo, na perspectiva empírica, Bergson retoma os resultados de Matéria e memória, uma vez que esse livro ceifara as pretensões materialistas de comprovação pelos fatos. Ele acaba, por assim dizer, a obra de 1896, pela identificação do epifenomenismo com o paralelismo (inatualidade do materialismo), levando a uma consequência fundamental: a nova metafísica, apresentada no livro, mesmo não sendo construída para se opor ao paralelismo, é a concepção da relação da alma com o corpo (da matéria com o espírito) que permite de fato superá-lo.

Ao escrever Matéria e memória, Bergson retoma o problema da união do corpo com a alma no ponto em que o deixara Descartes. Nesse momento, como afirmamos, o paralelismo ainda não fora descoberto como fonte dissimulada do epifenomenismo, não sendo relevante para as questões daquele contexto. Elas diziam respeito à redução do psíquico ao corpóreo, nas ciências, e à falta de uma metafísica que se colocasse no debate por dentro dele - pela abordagem dos fatos. Ora, a tentativa de Descartes de solucionar o problema da separação entre ambos era a que convinha retomar, para redirecioná-la. Mas, há algo fundamental aqui: ocorre que não se trata, na verdade, de reaver o problema do dualismo tal como fora posto por Descartes, e reposto na modernidade, e sim de reformular seus termos para melhor colocá-lo. No primeiro prefácio de Matéria e memória, vemos qual é o núcleo do problema e em que medida a sua solução depende não de uma nova resposta, mas da reformulação do próprio problema:

Se é verdade, com efeito, que nossa inteligência tende de modo invencível a materializar suas concepções e a atuar seus sonhos, pode-se presumir que os hábitos contraídos assim na ação, remontando até a especulação, virão perturbar em sua própria fonte o conhecimento imediato que temos de nosso espírito, de nosso corpo, e de sua influência recíproca (M.M., p. 444) ${ }^{45}$.

\footnotetext{
${ }^{45}$ Como expusemos, esse prefácio foi substituído pelo prefácio da sétima edição francesa a partir da sua publicação,
} 
O mesmo diagnóstico fora feito no Ensaio (muitos problemas ou dificuldades metafísicas nascem da confusão entre especulação e prática) e o mesmo método aplicado lá, ao problema da consciência, é retomado aqui, qual seja: delimitar “cuidadosamente a ação e o conhecimento”, de modo que "sejam iluminadas as obscuridades", o que significa que os problemas estabelecidos por motivo apenas de confusão sejam solucionados e os outros não mais tenham lugar para serem colocados $^{46}$. O método permite clarear o propósito de Bergson nesse livro, ampliando, de certo modo, o que fora obtido no Ensaio: trata-se de captar não só a vida interior do espírito, mas o ponto de contato entre ele e a matéria. Pensados através do espaço, o espírito aparece como um conjunto de elementos isolados e a matéria como um conjunto de objetos isolados, nenhum deles podendo ser apreendido em sua realidade, a qual é justamente o que têm em comum: a duração - ainda que haja uma diferença radical de tensão entre eles.

O Ensaio expusera a distinção essencial entre a duração e o espaço, assim como apresentara uma certa dualidade entre nosso “eu profundo” (fundado na duração) e o nosso “eu superficial”, que espacializa a duração. Matéria e memória resolverá essa última separação pelo estudo da memória, de modo a determinar a relação entre o espírito e a matéria e a compreender o motivo pelo qual deformamos nossas lembranças, espacializando-as (ela é a ligação entre as duas partes de nosso eu). Isto levará Bergson a encontrar no corpo a causa da espacialização das lembranças (devido às necessidades de sobrevivência ou da ação) e a sustentar que a natureza última da matéria não é uma estrutura espacial (matéria e espaço não são a mesma coisa), já que ela é essencialmente constituída por movimentos indivisíveis - é a dimensão mais distendida da duração. Assim, ele proporá uma solução nova para o problema tradicional do dualismo e que consistirá em compreender tanto a diferença entre a matéria e o espírito, quanto a sua unidade. Tal solução é resultado da teoria dos "planos de consciência” que fora o ponto de partida do livro, como Bergson afirma no primeiro

\footnotetext{
em 1911 (fora escrito, primeiramente, para a tradução inglesa do livro, um ano antes). Assim, para ter acesso a ele é necessário consultar uma edição que lhe seja anterior ou alguma edição posterior das obras de Bergson, que o apresente, contextualizando a sua supressão. No que se refere ao nosso caso, consultamos a recente reedição das obras de Bergson, pela PUF, “Le choc Bergson: La première édition critique de Bergson”, sob a direção de Frédéric Worms. Todos os livros de Bergson foram reeditados por ela nos últimos anos no formato de um dossiê crítico composto por: notas explicativas; notas históricas; notas que remetem o leitor de uma para as outras obras do autor em que a mesma temática é abordada; textos "avulsos" de Bergson; textos de críticos que se referem ao tema ou ao livro em questão; sugestão bibliográfica; e, enfim, uma tábua analítica do livro. Trata-se de um trabalho de extrema importância para os estudiosos de Bergson, e que fora essencial para o trabalho que ora apresentamos, de modo que devemos expressar o quanto lhe devemos aqui, ou seja, em toda a tese.

${ }^{46}$ Sobre a diferença bergsoniana entre "problemas inexistentes" e "problemas mal colocados", conferir o livro de Gilles Deleuze, Bergsonismo, p. 10 e seguintes.
} 
prefácio $^{47}$, ainda que seja objeto do terceiro capítulo do mesmo, e que implica um dualismo capaz de se confrontar com a hipótese materialista da localização cerebral das lembranças.

A tese principal do livro, defendida ao longo de seus quatro capítulos, é a de que o cérebro não cria nem contém representações. Com essa intenção, ele aborda temas essenciais de psicologia e de filosofia, mostrando que é tanto por razões empíricas quanto metafísicas que o cérebro não pode ser tomado por um equivalente do pensamento. Ele é um centro no qual se trocam movimentos recebidos e realizados por um organismo vivo no meio em que se encontra. Tal é a hipótese construída, no primeiro capítulo de Matéria e memória, sobre o papel do cérebro na percepção. O livro se inicia num plano de raciocínio a priori que levará à exigência de verificação de sua hipótese por meio de fatos empíricos concernentes à memória, o que os capítulos centrais se encarregam de fazer, pela discussão das afasias (segundo capítulo) e pela concepção dos planos de consciência (terceiro capítulo). O exame dos casos patológicos que, à primeira vista, parecem confirmar a tese epifenomenista, permite que Bergson faça o espírito “descer das alturas” às quais fora remetido, “por vários filósofos desde Platão”, e se coloque na fronteira comum à psicologia e à fisiologia ${ }^{48}$, o que significa que lidar com os fatos não será algo indigno à filosofia ${ }^{49}$, e sim condição necessária para a precisão da qual ela muitas vezes carece. Ao reduzir a separação entre a alma e o corpo, mesmo mantendo a diferença de natureza entre ambos, a explicação da união ganha em precisão e colaboração com a ciência. Opondo-se à construção teórica externa e anterior aos fatos, a explicação

\footnotetext{
47 “O ponto de partida de nosso trabalho foi a análise que se encontrará no terceiro capítulo do livro. Nós mostramos nesse capítulo, com o exemplo preciso da lembrança, que o mesmo fenômeno do espírito interessa, ao mesmo tempo, uma multidão de planos de consciência diferentes, marcando todos os graus intermediários entre o sonho e a ação: é no último desses planos, e apenas no último, que o corpo interviria” (M.M., p. 444).

${ }^{48}$ Psicologia e fisiologia são referências constantes nas obras de Bergson. Em Matéria e memória, sobretudo no primeiro capítulo, uma referência constante também será a disciplina que se intercala entre ambas e que surgiu no século XIX, a saber, a psicofisiologia. No Ensaio, ela é contundentemente questionada, quando o filósofo analisa a tese de Fechner sobre o aumento de uma intensidade sentida e que, para ele, poderia ser medida, como herdeira da concepção kantiana de grandeza intensiva, conforme vimos rapidamente na nota 2. Outros importantes representantes da psicofisiologia são: H. Lotze (1817-1881), H. Spencer (1820-1903), W. Wundt (1832-1920), H. Maudsley (18351918). Na definição feita por Wilhelm Wundt, e inserida nas notas da edição crítica de Matéria e memória, lemos que: "A fisiologia difunde sua luz sobre esses fenômenos biológicos percebidos por nossos sentidos externos. Na psicologia, o homem se vê, por assim dizer, de dentro e procura explicar a si mesmo o encadeamento dos fatos que essa observação interna lhe oferece. [...] A experiência interna é continuamente infuenciada pelos agentes externos, e nossos estados internos exercem frequentemente uma ação decisiva sobre a evolução do fato externo. É assim que se forma um círculo de fenômenos biológicos simultaneamente acessíveis à observação externa e interna; um domínio limítrofe entre a psicologia e a fisiologia e que será convenientemente atribuído a uma ciência particular que é a intermediária delas” (W. Wundt, Psychologie physiologique, tr. E. Rouvier, Paris, Alcan, 1886, p. 1 apud Matière et memoire, p. 312-313). Para Worms, o adversário de Bergson no primeiro capítulo, assim como em todo o livro, é a teoria da percepção de Taine, para a qual os choques nervosos dos elementos internos do conhecimento se tornam, em nós, sensações e, depois, imagens (cf. Worms, F. Introduction à Matière et mémoire, p. 67).

${ }^{49}$ Em "A alma e o corpo" lemos que: o "metafísico não desce facilmente das alturas na quais ama se colocar. Platão o convidava a se voltar para o mundo das Idéias [...]. Ele hesita entrar em contato com os fatos, quaisquer que sejam, e mais ainda quando se trata das doenças mentais: acreditaria sujar as mãos” (E.S., p. 38).
} 
proposta e levada a cabo por Bergson, nos dois capítulos centrais de Matéria e memória, não os precede, sendo, ao contrário, uma concepção diretamente sugerida por eles. O que a experiência mostra, no que tange à relação entre corpo e alma, é a solidariedade entre ambos e de nenhum modo a correspondência. Isto será confirmado por Bergson em todos os textos que abordarem o paralelismo como, por exemplo, o artigo “A alma e o corpo” ${ }^{50}$, o qual, além da crítica história, retoma a abordagem empírica de Matéria e memória. Esse artigo e o prefácio da sétima edição do livro deveriam servir como uma espécie de introdução a ele, segundo palavras de Bergson confiadas a seu amigo Chevalier, que as transcrevera no livro Entretiens avec Bergson ${ }^{51}$, e o novo prefácio deveria substituir o primeiro em todas as futuras edições do livro. Ambos indicam que, quando se trata de examinar o que os fatos revelam sobre a relação entre corpo e alma, devemos nos transportar para o "terreno da memória”, que nele têm um lugar privilegiado, tal como lemos no prefácio da sétima edição: “Não só os documentos são aqui de uma abundância extrema (que se almeje apenas a massa formidável de observações recolhidas sobre as diversas afasias!), mas em nenhuma parte, tanto quanto aqui, a anatomia, a fisiologia e a psicologia conseguiram se prestar um apoio mútuo"52 (M.M., p. 5). De modo que o estudo da memória, ou da memória das palavras mais especificamente, permite ao filósofo, ou ao cientista, se colocar no ponto de encontro dessas três disciplinas. No momento em que Matéria e memória foi escrito, muito já tinha sido dito sobre a afasia e muito ainda era dito ${ }^{53}$. Algumas versões sobre esse problema intentavam estabelecer as localizações exatas das perturbações que levavam à incapacidade de atingir as lembranças. O exame

\footnotetext{
50 “O que nos diz, com efeito, a experiência? Ela nos mostra que a vida da alma ou, se vocês preferirem, a vida da consciência, está ligada à vida do corpo, que há solidariedade entre eles, nada mais” (E.S., p. 36).

${ }^{51}$ Cf. Chevalier, J. Entretiens avec Bergson. Paris: Plon, 1959; p. 35.

52 Apoio não necessariamente fundado sobre a confirmação empírica, como vimos no tópico anterior, já que, por exemplo, a idéia das funções orgânicas permaneceu inalterada, apesar dos avanços do conhecimento anatômico.

${ }^{53}$ Lemos na "Introduction au dossier critique" de Matéria e memória, de Camille Riquier, responsável por esse livro na edição crítica da obra de Bergson, à qual nos referimos anteriormente, alguns esclarecimentos sobre as discussões em torno da questão da afasia no contexto do livro. A parte abaixo transcrita nos fornece uma idéia do lugar de destaque que essa questão ocupava naquele momento. “Em 1986, a afasia é um objeto maior que reúne para além de neurofisiologistas. Ela já tem seus historiadores e certas descobertas são erigidas em dogmas científicos. Após os esforços vãos de Franz Gall para localizar a memória nos relevos cranianos, Paul Broca acreditou encontrar, em 1861, o lugar da palavra na terceira circunvolução frontal esquerda. Sua lesão levava a uma aphemie, ou seja, uma afasia na designação que Trousseau adotaria mais tarde. Era, em realidade, apenas o centro motor, coordenando os movimentos necessários à articulação das palavras: o doente compreende o que ele ouve e o que ele lê, mas não pode se exprimir oralmente. Em 1874, ao lado da afasia motora, Wernicke descobre a afasia sensorial: o doente ouve o que é dito, mas não compreende. Não há uma, mas memórias parciais, cada variedade de memória devendo ter sua sede no cérebro. [...] Dois anos mais tarde, após as primeiras descrições de Bastian, Kussmaul pode cindir a afasia sensorial em duas formas distintas: a sudez verbal e a cegueira verbal. A distinção foi, em seguida, estabelecida sobre um ponto de vista clínico-anatômico pela escola francesa, e Charcot pôde descrever quatro tipos de afasia [...] conforme às quatro imagens que é preciso associar para constituir uma palavra (ouvida, lida, pronunciada, escrita): a surdez verbal, a cegueira verbal, a afasia motora e a agrafia. Em seguida, os esquemas se conplicaram, na esperança de conciliar os casos clínicos, sempre mais numerosos, com as diferentes lesões descobertas. É nesse período dito dos esquemas, que
} 
de Bergson se voltará para esses casos porque eles dão munição à psicologia edificada sobre base fisiológica e que interpreta os estados de consciência como elementos regidos pela lei de associação, que se aplica a elementos isolados e inertes ${ }^{54}$. Ao mesmo tempo empírico e negativo, o estudo das afasias mostra que lesões no cérebro não afetam o conteúdo psicológico em si mesmo, mas apenas uma memória motora que permite a sua atualização. As localizações cerebrais dizem respeito somente às funções do organismo e não aos conteúdos determinados da representação. O problema é que elas impedem que eles sejam invocados, uma vez que têm necessidade de se inserir em um quadro motor que dê ocasião à representação distinta. A partir do modelo de funcionamento do cérebro, Bergson é conduzido a um dualismo psicológico segundo o qual os seus mecanismos corporais são considerados uma parte extrema e decisiva da vida psicológica, ou melhor, a "ponta material da vida mental”. Esta é composta por uma variedade de planos, reunindo os acontecimentos passados que constituem um indivíduo psicológico. As análises das localizações abrem caminho para a sugestão de uma nova hipótese sobre a relação do corpo com a alma, mais "fiel aos fatos”, segundo a qual o espírito traspassa uma multiplicidade de planos de consciência (mais ou menos dilatados ou contraídos), transbordando infinitamente o corpo - sua ponta mais contraída, pela qual se insere no mundo exterior ${ }^{55}$. Em linhas gerais, essas são as questões e apostas do livro, que não cabe desenvolver aqui. Apontamo-las apenas como contraponto às teses que Bergson renuncia. A este respeito, cabem algumas palavras acerca do "Segundo prefácio", as quais reenviam para o que consideramos, neste capítulo, como a última dimensão da crítica de Bergson ao paralelismo, objetivo do nosso trabalho até o momento.

No prefácio da sétima edição, Bergson menciona as concepções às quais se resumem os estudos (poucos, no seu entender) sobre a relação do espírito com o corpo: "as que se limitam a constatar a 'união da alma com o corpo' como um fato irredutível e inexplicável”, o que nos remete diretamente a Descartes, tal como vimos anteriormente ${ }^{56}$; “as que falam vagamente do corpo como

\footnotetext{
Charcot inaugura e Freud encerra, que Bergson intervém” (M.M., p. 289).

${ }^{54}$ A teoria associacionista do espírito constitui o centro da crítica bergsoniana no que concerne à psicologia. O Ensaio se opusera a essa concepção, mostrando seus equívocos, e Matéria e memória também se confronta com ela, ao considerar a questão da memória e das localizações. O seu erro consiste em considerar os estados de consciência e, portanto, as lembranças como elementos isolados e justapostos (como átomos). Nas suas palavras, a concepção associacionista da vida do espírito "tem a tendência constante da inteligência discursiva de recortar todo progresso em fases e de solidificar, em seguida, as fases em coisas; e como ela nasceu, a priori, de uma espécie de preconceito metafísico, ela não tem nem a vantagem de seguir o movimento da consciência, nem o de simplificar a explicação dos fatos” (M.M., p. 139-140).

${ }^{55}$ Sobre a metáfora do cone e a da faca (é a ponta que o faz penetrar na matéria), cf. M.M., p. 169, 181. A lembrança representa o ponto de interseção entre o espírito e a matéria (prefácio da sétima edição) e o cérebro "constitui o ponto de inserção do espírito na matéria” (E.S., p. 47).

${ }^{56}$ Conferir a nota 28 deste trabalho, na qual expusemos a leitura de Bergson das cartas de Descartes à Princesa Elisabeth sobre esse tema.
} 
um instrumento da alma”, o que nos remete a Berkeley, citado um pouco antes no texto; e, por fim, “não resta praticamente outra concepção da relação psicofisiológica que a hipótese 'epifenomenista' ou a hipótese 'paralelista', que chegam, uma e outra, na prática - quero dizer na interpretação dos fatos particulares -, às mesmas conclusões” (M.M., p. 4). A primeira concepção é inconveniente porque, ao constatar as dificuldades presentes na compreensão da relação, de modo a não sacrificar nenhum dos seus termos, abre mão de conhecê-la. A segunda não pode ser admitida por Bergson, porque nem a alma é um “efeito” do cérebro, nem o corpo é um instrumento da alma (ou algo como um “reflexo” dela, como lemos em A energina espiritual, em outro contexto), ou seja, a relação não é de subordinação ou constatação de hierarquia ${ }^{57}$. Ora, Bergson se opõe desde o início desse prefácio às concepções de Descartes e Berkeley. Ele o inicia pela definição de imagem no livro, que fora objeto de muitas críticas, distinguindo-a justamente do que seria o seu equivalente nas concepções realista e idealista ${ }^{58}$. Elas ocuparão uma parte central do primeiro capítulo do livro, no qual Bergson tentará escapar às aporias desses “sistemas de notação”, pela demonstração de que, para tanto, é preciso manter a separação entre os pontos de vista de ambos. Ao identificar os problemas presentes nessas concepções, contrapondo-lhes a sua própria concepção de um “campo de imagens” e do lugar do corpo próprio nele, o filósofo demonstra que cada uma delas é, de algum modo, conduzida à outra. Não solucionam o problema da relação, e terminam em contradição consigo mesmas:

O problema pendente entre o realismo e o idealismo, talvez mesmo entre o materialismo e o espiritualismo, se põe, portanto, para nós, nos termos seguintes: De onde vem que as mesmas imagens podem entrar, ao mesmo tempo, em dois sistemas diferentes, um em que cada imagem varia por ela mesma e na medida bem definida em que sofre a ação real das imagens circundantes, o outro em que todas variam por uma só, e na medida

\footnotetext{
57 Tendo em vista que o espírito transborda o corpo, poderíamos supor uma hierarquia, já que este último corresponde apenas à parte "atuável” da memória. Porém, disso não segue que ele seja "um instrumento” como algo cujo sentido (função e definição) dependeria de outro. O corpo, ao contrário, tem um papel fundamental na filosofia bergsoniana: é ele quem faz a ligação entre matéria e memória, por ser o ponto comum entre as percepções e as lembranças, ainda que nenhuma delas esteja nele - a percepção é uma dimensão dos próprios objetos exteriores, e as lembranças se conservam no tempo, entendido como aquilo que define uma história singular ou um caráter, uma "totalidade confusa" e "melódica” que somos nós (as lembranças não estão em algum lugar material, e perguntar pela conservação ou localização, nesses termos, é incorrer em um erro categorial, ou seja, usar os termos do espaço para tratar da duração).

${ }^{58}$ Para Bergson, Descartes "colocava a matéria muito longe de nós quando a confundia com a extensão geométrica” (M.M., p. 3), e Berkeley, para aproximá-la de nós, “a confundia com o nosso espírito”. Nesse livro, Bergson critica tanto o realismo quanto o idealismo, e os representantes maiores dessas duas formas de conhecimento são, a seus olhos, Descartes e Berkeley respectivamente. Assim, seu ponto de partida é a consideração da matéria como um "conjunto de imagens", sendo a "imagem” entendida como "uma existência que é mais do que o idealista chama de uma representação, porém menos do que o que o realista chama de uma coisa - uma existência situada ao meio do caminho entre a 'coisa' e a 'representação'” (M.M., p. 1).
} 
variável em que elas refletem a ação possível dessa imagem privilegiada? (M.M., p. 20-21).

O fato é que nenhum deles pode proporcionar uma explicação satisfatória da relação, porque reduzem a realidade à exterioridade ou à interioridade, e são obrigados a explicar o que fora excluído, seja pela constatação da existência de uma “imagem central”, seja pela necessidade de reconhecer que as imagens variam por elas mesmas, e não para uma "imagem privilegiada”, ou a ciência seria impossível. Ambos têm a pretensão de ultrapassar a dualidade de pontos de vista pela afirmação de uma unidade entre a realidade e o conhecimento, o que é compreensível se se pensar que, para um (“realista”), é inadmissível que nossas representações possam diferir das coisas, e, para outro (“idealista”), é inadmissível que existam coisas inacessíveis às nossas representações. O erro de ambos remete, para Bergson, a um fundamento $\operatorname{comum}^{59}$ (a unidade entre a realidade e o conhecimento), o que os leva ao sistema de notação contrário ao que assumiam previamente - o realismo acaba deslizando para o idealismo e vice-versa, e esse é também o núcleo da crítica final de Bergson ao paralelismo, tal como veremos no próximo tópico.

A crítica a ambos, no prefácio da sétima edição, sugere que o livro se inicia pela recusa das teorias de conhecimento realistas ou idealistas para se confrontar com o epifenomenismo, o qual parte de um dos termos da relação para dele retirar o outro, como um efeito do primeiro. Nos sistemas realistas e idealistas, a contradição é também consequência de uma interdição que lhes é inerente, a saber, a negação de uma relação causal entre modos distintos de ser. No caso do epifenomenismo não se verificaria, em princípio, a mesma interdição, e a sua formulação seria uma decorrência da verificação empírica, devendo ser contestada, como dissemos, nesse mesmo terreno. Ainda que isso tenha sido feito, em Matéria e memória, a questão parece não ter sido resolvida, e é a sua persistência que leva Bergson à constatação de que a sua origem não é empírica, mas teórica e, enquanto tal, deve ser submetida às mesmas exigências e interdições presentes na tese da qual é apenas uma versão menor: o paralelismo. O prefácio, como assinalamos, identifica epifenomenismo e paralelismo no que tange às suas conclusões (nos dois casos, considera-se que se pode "ler" no corpo, ou no cérebro, tudo o que se passa na alma) e o artigo sobre “A alma e o corpo”, posterior a ele cerca de um ano, nega de uma vez por todas que o primeiro possa ser considerado uma concepção científica ou empírica - demonstrando a sua origem filosófica. Uma vez constatada a

\footnotetext{
${ }^{59}$ Sobre isso, conferir o livro de Frédéric Worms, Introduction à Matière et mémoire, do qual assimilamos esse aspecto da crítica de Bergson: "Primeiramente, o erro do realismo e do idealismo é reconduzido a um fundamento comum. Se eles querem ultrapassar a distância entre o real e o conhecimento, é precisamente porque essa distância é insuportável para fundar o conhecimento do real. [...] Mas, pode-se suportá-la muito bem se se supõe que o alvo e a origem da
} 
origem, é nela - no terreno do paralelismo, e não mais no do epifenomenismo - que devem ser realizadas as provas ou contraprovas finais quanto à sua pertinência. Esse mesmo artigo, citado no prefácio da sétima edição do livro, aponta para a terceira dimensão da crítica bergsoniana ao paralelismo e que se refere justamente à contradição inerente a ele, uma vez que a hipótese de uma equivalência entre o cerebral e o mental, nas palavras de Bergson, "exige que adotemos ao mesmo tempo dois pontos de vista opostos e empreguemos simultaneamente dois sistemas de notação que se excluem” (E.S., p. 49). Realismo e idealismo são explicações insuficientes e que tendem à contradição. O paralelismo, por sua vez, é contraditório em seus próprios termos. Não sendo científica, a hipótese epifenomenista é também, ou sobretudo, contraditória consigo mesma, pois é herdeira do paralelismo, que nega a relação causal entre corpo e consciência, ao mesmo tempo em que não se submete à mesma interdição. Em Matéria e memória, podemos dizer que o epifenomenismo é visado (os fatos empíricos da psicologia ou da fisiologia que parecem ir ao seu encontro) e a filosofia moderna é atingida.

O paralelismo, ao afirmar a equivalência dos dois termos da relação, não fugirá ao equívoco do qual padecem o realismo e o idealismo, no entender de Bergson, e será “ainda mais” contraditório, pois a sua própria formulação revela a ilusão constitutiva da contradição. A crítica aos dois “sistemas de notação” mencionados, feita durante o desenvolvimento da teoria da percepção no primeiro capítulo do livro de 1986, Matéria e memória, é prolongada na crítica ao paralelismo do último texto de A energia espiritual, ao qual nos dedicaremos a seguir.

Realizada a abordagem empírica e a crítica histórica do epifenomenismo, o que revelou a sua “origem paralelista”, a análise desta concepção em si mesma, nos seus próprios termos, revelará a contradição na qual ela se assenta, finalizando tanto a crítica ao paralelismo quanto ao epifenomenismo, visto que ambas acabaram se fundindo em uma única crítica. E é contra essa concepção que, ao fim e ao cabo, Bergson propõe uma nova maneira de filosofar, tal como podemos ler no final do artigo sobre “A alma e o corpo”. Nele, há um fechamento da problemática do epifenomenismo. Para tanto, o filósofo volta brevemente aos temas desenvolvidos em Matéria e memória, a que também nos referimos sumariamente ${ }^{60}$, insistindo, contudo, na diferença entre a hipótese metafísica da qual o epifenomenismo é apenas uma versão empobrecida e a sua própria hipótese. O paralelismo, sendo uma construção a priori, anterior aos fatos, fez escola não porque fosse a explicação mais adequada, e sim porque dava aos materialistas a mesma certeza

\footnotetext{
representação não é o conhecimento, mas a ação” (cf., op. cit., p. 38).

${ }^{60}$ Para um estudo detalhado de Matéria e memória, conferir o livro de Frédéric Worms: Introduction à Matière et mémoire de Bergson. Paris: PUF, 1997.
} 
“proporcionada pela geometria”. A teoria dos planos de consciência é, por sua vez, oposta a ele, pois parte dos fatos, ao invés de precedê-los, e porque não se pretende uma verdade imperturbável, mas, ao contrário, é apresentada como provável e suscetível de aperfeiçoamento a partir das novas descobertas científicas. Com essas palavras, Bergson encerra a conferência, contrapondo a sua hipótese metafísica àquela a que se reduzia “o materialismo atual”:

... é preciso optar, em filosofia, entre o puro raciocínio que visa um resultado definitivo, imperfectível, já que é considerado perfeito, e uma observação paciente, que só dá resultados aproximativos, capazes de serem corrigidos e completados indefinidamente. O primeiro método, por ter querido nos oferecer a certeza de uma vez por todas, nos condena a ficar sempre no simples provável ou, de preferência, no puro possível, pois é raro que ele não possa servir, indiferentemente, à demonstração de duas teses opostas, igualmente coerentes, igualmente plausíveis. O segundo método não visa, primeiramente, senão a probabilidade; mas, como ele opera em um terreno no qual a probabilidade pode aumentar indefinidamente, ele nos conduz, pouco a pouco, a um estado que equivale praticamente à certeza. Entre essas duas maneiras de filosofar minha escolha está feita. Seria feliz se tivesse podido contribuir, por pouco que fosse, na orientação da de vocês (E.S., p. 59-60).

O último artigo de A energia espiritual, mencionado no prefácio da sétima edição de Matéria e memória e na conferência sobre “A alma e o corpo”, demonstra a contradição inerente ao paralelismo, que o faz servir à demonstração de teses opostas, e encerra a sua crítica.

\section{Análise lógica}

Lido no Congrès de Philosophie de Genève, em 1904, e publicado na Revue de métaphysique et de morale, sob o título "O paralogismo psicofísiológico”, o artigo "O cérebro e o pensamento: uma ilusão filosófica” é o texto mais antigo dos que compõem A energia espiritual (1919) no que diz respeito à problemática mais propriamente filosófica ${ }^{61}$ do livro. No fundo, ele se

\footnotetext{
${ }^{61}$ Nessa coletânea, estão reunidos, nas palavras de Bergson, "os trabalhos que se voltam para problemas determinados de psicologia e de filosofia”. O primeiro texto, “A consciência e a vida” (1911) retoma muitos dos "resultados” de $A$ evolução criadora, apresentando-os a partir da articulação de várias linhas de fatos que, digamos, “estruturam” o artigo. Esse texto, o segundo (“A alma e o corpo”) e o último apresentam uma temática mais propriamente filosófica, enquanto os quatro que compõem o "recheio" do livro discutem temas mais psicológicos, a saber: "Fantasmas de vivos e pesquisa psíquica”, “O sonho”, “A lembrança do presente e o falso reconhecimento”, “O esforço intelectual”. De qualquer modo, a dupla característica dos mesmos (artigos que tratam de problemas de psicologia e de filosofia) diz respeito mais a dois aspectos presentes em todos os textos que a uma cisão entre eles. Frédéric Worms, comentando a ordem dos textos de A energia espiritual, vê nela uma tripla ambição: "resolver os grandes problemas metafísicos
} 
diferencia de todos os outros porque o seu foco não é a abordagem, direta ou indireta, de uma teoria positiva (uma nova concepção a partir do confronto com outras, filosóficas ou científicas), e sim o desenvolvimento de uma argumentação crítica que demonstra que o tema abordado não constitui um problema filosófico, sendo apenas uma ilusão, o que leva à conclusão de que a solução está na sua dissolução pela denúncia das teses contraditórias que a compõem. É como se, não tendo sido suficiente revelar a origem histórica do paralelismo ou mostrar que os fatos negam tal tese, Bergson se voltasse novamente para a demonstração de que se trata de um “falso problema”, cuja origem está na própria constituição dos nossos procedimentos de conhecimento a partir da inteligência. “ $O$ cérebro e o pensamento: uma ilusão filosófica” completa a crítica ao paralelismo por meio de um golpe fatal: ele refuta a lógica que o sustenta, atingindo-o internamente e encerrando definitivamente a questão. Caberá entender, posteriormente, qual a origem da ilusão, pela gênese da própria inteligência, o que será feito noutra dimensão crítica, em A evolução criadora, à qual nos reportaremos no próximo capítulo. Cessando a problemática paralelista, a conferência sobre o paralogismo do paralelismo interrompe também o círculo vicioso entre ciência e filosofia, abrindo a temática $^{62}$ que é o núcleo da segunda coletânea de artigos publicada pelo autor, $O$ pensamento e o movente (1934), dedicada, sobretudo, ao estudo do método filosófico. Acompanharemos a sua argumentação, marcando os principais momentos da crítica contida no exame lógico do paralelismo e apontando outros momentos da obra bergsoniana que nele ressoam e se desdobram.

A conferência reproduzida no último artigo de A energia espiritual foi pronunciada meses depois do final do curso sobre a "História das teorias da memória”, em 1904. Como mencionamos anteriormente, o curso tinha uma dupla intenção: proceder a um exame empírico das teorias da memória, confrontando-as com os resultados obtidos em Matéria e memória, e realizar uma exposição da história das doutrinas filosóficas consagradas à relação entre corpo e alma. Na primeira parte, ele repõe as razões empíricas e metafísicas pelas quais o cérebro não pode ser tomado como um equivalente do pensamento consciente. Na segunda, ele revela a origem histórica da problemática psicofisiológica com a qual o livro se deparara anos antes (a hipótese das localizações das lembranças) e explicita a circularidade entre ciência e filosofia. O artigo retoma, como “A alma e o

tradicionais, confrontando-se, aliás, com as teorias mais autorizadas a esse respeito (tal como o dualismo cartesiano); resolver também problemas científicos muito específicos de seu tempo, confrontando-se, dessa vez, com o estado de saberes contemporâneos; conduzir, enfim, uma crítica a priori de certos argumentos sobre o espírito, o paralogismo do paralelismo sendo tratado aqui, com efeito, da mesma maneira com que Kant tratou o paralogismo da psicologia racional na Crítica da razão pura [...]. Trata-se de uma mesma filosofia que conduz a esses diferentes resultados, mas a ordem do livro, no entanto, obriga também a distinguir, de início, os registros, que são, em sua própria diferença, os de toda filosofia completa do espírito: metafísica, psicologia, teoria do conhecimento” (E.S., p. 8; grifo nosso).

${ }^{62}$ A separação metódica entre ambas. 
corpo”, a abordagem histórica de maneira rápida e esquemática, numa curva genealógica pela qual vemos a tese do paralelismo passar do cartesianismo ao materialismo do século XVIII, antes de ser incorporada pela fisiologia e pela psicologia contemporâneas. Mas, aqui, interessa menos a história do que o artifício dialético subentendido pela tese, em qualquer contexto histórico, dissimulando a contradição insolúvel que a mantém. A sua análise conduz a dois ensinamentos: mostra “em qual direção a solução do problema deve ser buscada” e desvela o mecanismo de "uma das mais sutis ilusões do pensamento metafísico” (E.S., p. 193). De acordo com Bergson, ela repousa sobre uma ambiguidade e não pode ser enunciada corretamente sem se destruir a si mesma. A “afirmação dogmática do paralelismo psicofisiológico implica um artifício dialético pelo qual se passa de um sistema de notação a outro, que lhe é contrário, sem que se dê conta da substituição” (E.S., p. 193). Trata-se de "um sofisma” "natural ao nosso espírito”, sugerido pelos próprios termos em que a questão é posta. A argumentação bergsoniana contra o paralelismo se funda num novo argumento, que remete à teoria do conhecimento, de acordo com o qual não é apenas por razões empíricas e metafísicas que a equivalência entre o cérebro e o pensamento não pode ser estabelecida, mas também por razões, a priori, advindas tão somente da construção do raciocínio que ela implica.

No momento em que "O cérebro e o pensamento" foi escrito, a origem do determinismo contemporâneo tinha sido explicitada pela abordagem histórica do curso, de modo que, no artigo, vemos o determinismo ser remetido ao paralelismo ou o paralelismo ser definido com as palavras do Ensaio ou de Matéria e memória, utilizadas para definir o determinismo científico num momento anterior, em que ainda não havia sido feita a crítica genealógica. Desse modo, lemos que tanto os que sustentam a correspondência das duas séries, quanto os que fazem da consciência uma fosforescência, que se acrescentaria ao cérebro, admitem a equivalência ou paralelismo das duas séries, de modo que a tese pode ser formulada assim: "Um estado cerebral sendo posto, um estado psicológico determinado se segue”; ou pela idéia de que "uma inteligência sobre-humana, que assistisse ao cruzamento de átomos do qual o cérebro é feito, e tivesse a chave da psicofisiologia, poderia ler em um cérebro que trabalha tudo que se passa na consciência correspondente”; ou ainda pela afirmação de que "a consciência não diz nada mais do que o que se passa no cérebro: apenas o exprime em outra língua” (E.S., p. 191). O paralelismo é definido pela equivalência que, por sua vez, pode ser entendida como correspondência ou como produção da consciência pelo cérebro, na perspectiva assumida por Bergson no contexto do artigo sobre o paralogismo, e mantida até o último tratamento da questão, em “A alma e o corpo”. Ou seja, após a compreensão histórica do epifenomenismo, que o remete ao paralelismo, a crítica incidirá sobre este último, ainda que ele seja definido também com os termos do primeiro, sua versão mais empobrecida. Logo no início do artigo 
sobre o paralogismo, Bergson explicita que não se trata de discutir, como antes, as causas ou o significado da equivalência, mas a própria equivalência (E.S., p. 191). E, nesse sentido, a tese do paralelismo será atacada não somente por fazer do cérebro um equivalente do pensamento, mas também por fazer dele ou do estado cerebral um equivalente da totalidade dos objetos do universo.

Para introduzir o exame, Bergson define os dois "sistemas de notação" - ou as “duas maneiras diferentes de compreender a análise do real” (E.S., p. 194) - utilizados quando se considera os objetos exteriores: são tratados como “coisas” (realismo) ou como “representações” (idealismo). Antes de desenvolver um pouco mais as idéias que compõem esses sistemas, e para entender o alcance da crítica aqui presente, é necessário uma breve referência à noção de notação, mais especificamente. Para tanto, devemos lembrar que o filósofo havia escrito, um ano antes, o texto “Introdução à metafísica” (1903), no qual considerava as diferenças fundamentais entre dois modos de conhecimento: a intuição (conhecimento interno e, portanto, inteiro do objeto) e a análise (conhecimento externo e, portanto, parcial). O conhecimento externo não diz respeito à extração de partes reais do objeto, e sim ao recorte ou à abstração de porções simbólicas dele. Os sistemas de notação identificam-se a maneiras diferentes de compreender a análise do real: são modos de conhecimento por signos ou símbolos - a análise é uma notação do real. A idéia de que os sistemas considerados se definem justamente por seu caráter simbólico evidencia, por um lado, o plano do exame (lógico) a que serão submetidos, e, por outro lado, deixa claro a exclusão que eles operam, e que se refere a nada menos do que à própria realidade. Nesse sentido, Frédéric Worms compreende que a diferenciação bergsoniana, ou “a oposição desse conhecimento simbólico e do conhecimento intuitivo, um aplicado sobre partes e o outro, sobre o todo, substitui a oposição do fenômeno e da coisa em si em Kant”, uma vez que, “ao nos colocarmos diante de objetos 'exteriores', somos privados da intuição metafísica da matéria como um todo"63. Os “sistemas de notação” referem-se, portanto, no entender de Bergson, apenas à percepção e ao conhecimento científico do real, que é necessariamente analítico, e não à realidade última de todas as coisas. É nessa perspectiva que idealismo e realismo são, então, “apresentados”.

Para o idealismo, não há nada mais, na realidade, do que o que aparece para a consciência. Nada há de virtualidade nas coisas: tudo o que existe é atual ou poderá se tornar, ou melhor, é dado

${ }^{63}$ WORMS, F. "Le paralogisme du parallélisme: Le Cerveau et la Pensée de Bergson (1904) et sa portée philosophique" in Cahiers Philosophiques, CNDP, 1995, p. 156. Nesse texto, Worms aponta certas alusões de Bergson, mesmo que implícitas, à Crítica da razão pura de Kant, sobretudo à parte da "Dialética transcendental" que trata dos paralogismos do pensamento racional. Por ser um estudo preciso sobre a problemática que nos interessa aqui (a definição do paralelismo como um paralogismo), consideramo-lo uma referência indispensável para esta parte de nosso trabalho, e para qualquer estudo sobre a mesma temática (devemos a ele parte de nossa abordagem desenvolvida aqui). 
ou pode se dar na representação que temos e cujas articulações são as próprias articulações da realidade. O realismo repousa sobre a hipótese inversa: a matéria existe independentemente da representação, o que significa que há uma causa inacessível dessa representação, há virtualidades ocultas sob a percepção, que é do atual, e que as articulações, visíveis em nossa representação, são apenas relativas à nossa maneira de perceber (E.S., p. 194). Ainda que Bergson identifique a primeira concepção a um “idealismo à la Berkeley” e a segunda ao "realismo que a ele se opõe” (E.S., p. 195), remetendo ao cartesianismo que concebe o universo sensível como algo estruturado de modo subjacente por relações matemáticas, o artigo não analisa nenhuma filosofia em particular. Trata-se bem mais de uma demonstração independente de qualquer concepção histórica do idealismo ou do realismo. Os dois termos devem ser tomados como "termos convencionais" pelos quais "são designadas duas notações do real, em que uma implica a possibilidade e a outra a impossibilidade de identificar as coisas com a representação que elas oferecem à consciência humana”, ou ainda como “duas tendências” ou "dois postulados” que se excluem, sendo ilegítimo aplicar os dois ao mesmo tempo e na mesma relação (E.S., p. 195). É esta ilegitimidade que predomina no paralelismo, como Bergson pretende evidenciar, pois o objetivo do texto é justamente o de mostrar que, para a notação idealista, a afirmação de uma equivalência entre o estado psicológico e o estado cerebral implica contradição, o mesmo valendo para a notação realista, restando apenas à sustentação do paralelismo o emprego desses dois sistemas de notação ao mesmo tempo (E.S., p. 196).

Bergson se coloca, primeiramente, sob o ponto de vista idealista, considerando a percepção dos objetos que ocupam o campo visual, por certo momento, e que alcançam, por intermédio da retina e do nervo óptico, o mesmo campo visual, provocando uma modificação dos agrupamentos atômicos e moleculares do cérebro. A tese do paralelismo consistiria em sustentar que nós podemos, em posse do estado cerebral, "suprimir, por um golpe de mágica, todos os objetos percebidos sem nada mudar do que se passa na consciência, pois é esse estado cerebral causado pelos objetos, e não o próprio objeto, que determina a percepção consciente” (E.S., p. 197). Hipótese absurda para o idealismo que considera o cérebro como uma dentre todas as imagens que representam os objetos, o que significa que ele (parte) não poderia ser tomado como equivalente do todo. Dizer que a imagem do mundo circundante sai dessa imagem ou se exprime por ela seria contraditório, porquanto o mundo exterior e o mundo intracerebral são supostos da mesma natureza e o segundo é, por conseguinte, uma parte do campo de representação, enquanto a primeira preenche completamente o campo (E.S., p. 197). O centro da argumentação bergsoniana está nessa compreensão da relação da percepção com o cérebro como uma relação da parte com o todo, de modo que ele reprova a concepção idealista do paralelismo psicofisilógico por colocar a relação entre todo e parte como uma 
identidade tal qual "a parte é o todo"64 (E.S., p. 198). Passa-se inconscientemente de um ponto de vista idealista a um ponto de vista "pseudo-realista", ou desliza-se do idealismo ao realismo, pois parte-se do cérebro e seus movimentos interiores como representações, dentre outras, que são dadas com ele e em torno dele, mas acaba-se por erigir o cérebro e os movimentos intracerebrais em coisas, ou seja, causas ocultas sob certa representação, e cujo poder se estende infinitamente mais longe que o do que é representado (E.S., p. 198). Antes de terminar a abordagem do "ponto de vista idealista”, Bergson apresenta “os fatos” que “parecem encorajar esse deslize”, e eles dizem respeito à memória, pois ela faz crer em um conteúdo mental independente do contato externo com os objetos, então ausentes, e que pode ser suscitado por estados cerebrais determinados, correspondentes a lembranças determinadas (E.S., p. 199). Trata-se aqui do segundo aspecto da tese paralelista, a qual não se refere ao paralelismo entre estado cerebral e representações-percepções de objetos exteriores (paralogismo todo/parte), mas entre estado cerebral e representações-lembranças de objetos antes percebidos. Respondendo a esse novo aspecto do paralelismo, Bergson alude ao fato de que a lembrança, para o cérebro, age como um objeto, determinando reações motoras, e que estas reações motoras nascentes desenham alguns dos efeitos da representação que vai surgir e não a própria representação. Isto significa que, da mesma reação motora, podem seguir lembranças diferentes, não havendo uma lembrança determinada para um estado cerebral determinado ${ }^{65}$. Assim, o estado cerebral não é equivalente, no sentido do paralelismo, nem a um objeto atual (percepção), nem a um objeto virtual (lembrança), nem a qualquer estado psicológico determinado, porque ele se define por sua função relacional com os objetos, no âmbito do pensamento - o estado cerebral não é equivalente à representação, mesmo porque faz parte dela, na hipótese idealista.

Bergson passa, em seguida, para o ponto de vista do realismo, cujo princípio é supor, atrás de nossas representações, uma causa que difere delas. As teorias realistas variam quanto ao modo como consideram a relação de implicação entre os objetos exteriores e as modificações cerebrais, a saber: são epifenomenistas as que tomam os estados cerebrais por "verdadeiros criadores da representação"; outras supõem "à maneira cartesiana que os movimentos cerebrais ocasionam

\footnotetext{
64 "Formulada em uma língua rigorosamente idealista, a tese do paralelismo se resumiria, portanto, nessa proposição contraditória: a parte é o todo” (E.S., p. 198).

${ }^{65}$ Da mesma reação motora podem seguir lembranças diferentes, que se submeterão "a uma única condição comum, a de entrar no mesmo esquema motor: nisso consiste sua 'semelhança', termo vago nas teorias correntes da associação, e que adquire um sentido preciso quando o definimos pela identidade de articulações motoras” (E.S., p. 200; grifo nosso). Bergson não exclui a concepção de associação por semelhança, mas a redefine radicalmente. Isto ocorre em Matéria e memória, quando ele toma os termos "semelhança" e "contiguidade", essenciais às teorias correntes de associação, em um sentido necessário não porque referido ao conteúdo da representação, mas porque referente às condições fundamentais da vida. Para um aprofundamento desse assunto, conferir Matéria e memória (p. 181-188) e o livro de Frédéric Worms, Introduction à Matière et mémoire (p. 171-176).
} 
simplesmente a aparição das percepções conscientes”; para outras, enfim, “essas percepções e esses movimentos são apenas dois aspectos de uma realidade que não é nem movimento, nem percepção" (E.S., p. 201; grifos nossos). Esta última consiste em uma alusão direta ao espinosismo. Todas elas, não importando a sua versão, têm em comum, segundo o filósofo, a suposição da equivalência entre estados de consciência e estados cerebrais, bem como a assunção de que os movimentos da substância cerebral, considerados à parte, podem revelar o que se passa na consciência correspondente, para alguém que saiba decifrá-los. Contudo, essa pretensão de considerar o cérebro ou os movimentos intracerebrais à parte envolve uma contradição. Um idealista pode declarar isolável o objeto que lhe dá uma representação isolável, uma vez que o objeto não se distingue da representação. O realismo consiste justamente em rejeitar essa pretensão, considerando artificiais as linhas de separação que nossa representação traça entre as coisas, supondo, sob elas, um sistema de ações recíprocas e de virtualidades, ou seja, definindo o objeto não por sua entrada em nossa representação, mas pela solidariedade com o todo de uma realidade que se pode conhecer (E.S., p. 202). O paralelismo é equívoco em sua própria formulação porque exige que uma dupla contradição seja ultrapassada: por um lado, o cérebro é considerado uma configuração de movimentos apenas (aquilo que ele parece ser), o que significa que ele não pode ser equivalente a mais nada (é apenas uma parte), e, a despeito disso, o paralelismo acaba por sustentar a equivalência entre a parte e o todo; por outro lado, o cérebro é considerado diferente do que ele parece ser, já que a realidade íntima dos movimentos dos átomos que se realizam nele é constituída pela solidariedade com tudo o que está por trás de nossas percepções, o que significa que ele forma um "bloco indiviso” com os objetos que o determinam e que esse bloco, que é o todo da matéria, deve ser equivalente a si mesmo. Esta última contradição pode ser formulada “em linguagem estritamente realista”, nas palavras de Bergson, do seguinte modo: "Uma parte, que deve tudo o que ela é ao resto do todo, pode ser concebida como subsistindo quando o resto do todo se esvai. Ou ainda, mais simplesmente: Uma relação entre dois termos equivale a um deles” (E.S., p. 203). O sistema de notação realista não pode nunca se manter em estado puro, pois, para referir a uma realidade particular, ele tem de fazer a realidade coincidir com a representação, ou melhor, "realista no momento em que ele põe o real, ele se torna idealista desde que afirma qualquer coisa dele” (E.S., p. 204), ou não poderia “nem mesmo sonhar em considerar as partes isoladas da realidade para condicioná-las uma em relação à outra, o que é a própria ciência” (E.S., p. 205). Mas, ao fazer com que a cada parte da representação corresponda uma parte da realidade, o realista articula o real com a representação, estendendo a realidade no espaço, e “abondona seu realismo para entrar no idealismo, no qual a relação do cérebro com o resto da representação é evidentemente da parte com o todo” (E.S., p. 205-6). Em “O 
paralogismo psicofísiológico”, Bergson não coloca, portanto, realismo e idealismo simetricamente em lados opostos. O final da parte consagrada ao "ponto de vista realista”, que acabamos de resumir, mostra que o realismo não pode pôr o cérebro como algo independente sem cair no sistema de notação contrário, ou seja, ele não pode falar da realidade estabelecida, por ele mesmo, como um todo material estruturado segundo leis puramente matemáticas ${ }^{66}$. Realismo e idealismo são tratados nesse texto de uma maneira nova: não designam duas tentativas de redução dos pontos de vista sobre o real a um apenas, mas dois pontos de vista distintos - um que limita o real ao que ele parece ser para nós (idealista) e outro que supõe uma realidade diferente dos objetos aparentes (realista). Tais pontos de vista correspondem, assim, a níveis diferentes de conhecimento: o idealismo, ao conhecimento científico, e o realismo, ao conhecimento metafísico das coisas ${ }^{67}$, o qual é impossível na abordagem de um sistema de notação, ou seja, pela análise. Voltaremos aos desdobramentos dessa distinção a seguir. Antes, porém, é necessário retomar o "erro do paralelismo”, que diz respeito justamente à indistinção entre ambos, confundindo-os num mesmo argumento ou no mesmo plano de reflexão. Para tanto, citaremos a parte final da demonstração do paralogismo:

Falava-se primeiramente do cérebro tal qual o víamos, tal qual o destacávamos do conjunto de nossa representação: ele era pois apenas uma representação e estávamos no idealismo. A relação do cérebro ao restante da representação era então, repetimos, da parte ao todo. Disto passamos bruscamente para uma realidade que seria subjacente à representação: seja, mas então ela é subespacial, o que significa que o cérebro não é uma entidade independente. Só há, agora, a totalidade do real incognoscível em si, sobre a qual se estende a totalidade de nossa representação. Estamos no realismo; e, tanto neste realismo como no idealismo de há pouco, os estados cerebrais não são o equivalente da representação: é, repetimos, a totalidade dos objetos percebidos que entrará ainda (desta vez dissimulada) na totalidade de nossa percepção. Mas eis que, quando se trata do detalhe do real, continuamos a compô-lo da mesma maneira e segundo as mesmas leis da representação, o que equivale a não mais distingui-los um do outro. Voltamos, pois, ao idealismo, e deveríamos nele permanecer. Mas não. Conservamos realmente o cérebro tal qual é representado, mas esquecemos que, se o real está desdobrado na representação, estendido nela e não contraído nela, ele não pode mais encerrar as potencialidades e as virtualidades de que falava o realismo; erigimos, então, os movimentos cerebrais em equivalentes de toda a representação. Oscilamos, pois, do idealismo ao realismo e do realismo ao idealismo, mas tão rapidamente que nos acreditamos imóveis e, de alguma forma, a cavaleiro dos dois sistemas

\footnotetext{
66 "Estamos sempre mais ou menos no idealismo (tal como o definíramos), quando fazemos trabalho de cientista" (E.S., p. 205).

${ }^{67}$ Conferir o livro de Worms, Introduction à Matière et mémoire, p. 42-44, do qual retiramos resumidamente essa “conclusão”.
} 
reunidos num só. Esta aparente conciliação de duas afirmações inconciliáveis é a própria essência da tese do paralelismo ${ }^{68}$

A conclusão a que a crítica do paralelismo chega, portanto, é a de que se trata de uma tese cujo conteúdo não é preenchido por um objeto, mas somente pelo movimento oscilatório do espírito entre duas hipóteses antinômicas, e sua aparente conciliação. Ela não pode ser sustentada por nenhum dos dois sistemas de notação sem que se caia em contradição. O seu sucesso ou permanência, desde a metafísica clássica até a psicofisiologia contemporânea, deve-se a essa oscilação, que parece ser uma conciliação, e que é a sua própria essência. Mas, trata-se de uma aparente conciliação, uma vez que não há uma resolução dialética da contradição entre duas teses, e sim um "artifício dialético" que dissimula a contradição insolúvel tanto num quanto noutro sistema (dupla contradição). O paralelismo é um paralogismo porque emprega afirmações inconciliáveis (teses contraditórias) no mesmo argumento, devido à assunção de uma palavra em dois sentidos diferentes, e incompatíveis, em etapas distintas da mesma demonstração. A sua refutação depende da compreensão do que se subentende pela palavra “cérebro" ou do que nela se dissimula. De acordo com Frédéric Worms,

Trata-se de mostrar, em suma, que o paralelismo só pode se sustentar por uma passagem subreptícia de uma a outra dessas duas descrições do real, assim como o paralogismo da psicologia racional repousava, em Kant, na passagem ilegítima do eu como fenômeno ao eu considerado como sujeito do pensamento. O paralelismo é de fato uma anfibologia, no sentido kantiano do termo: ele consiste em confundir o cérebro como fenômeno e o cérebro como porção da coisa em si que é o universo material no qual estamos imersos como todos os outros corpos ${ }^{69}$.

$\mathrm{Na}$ perspectiva da crítica bergsoniana, contudo, a antinomia sustentadora do paralelismo psicofisiológico é naturalmente sugerida pelos termos dos quais a tese é composta - “o enunciado da questão já contém, em potência, o equívoco pelo qual ela será respondida” (E.S., p. 196) -, e a oscilação é sintoma, digamos, de certa faculdade de conhecimento (a inteligência), e não da natureza da razão humana ou da essência do conhecimento metafísico. Tal oscilação, que demonstra uma indecisão da inteligência, constitui, desse modo, uma ilusão filosófica - sendo todas as ilusões

\footnotetext{
${ }^{68}$ Utilizamos aqui a tradução feita pelo professor Franklin Leopoldo e Silva para a Coleção Os Pensadores, da editora Abril Cultural, 1a edição, 1974, p. $56-7$ (grifo nosso). Na edição francesa que empregamos até então, e à qual voltaremos a seguir, o trecho citado encontra-se nas páginas 206 e 207.

${ }^{69}$ WORMS, F., "Le paralogisme du parallélisme: Le Cerveau et la pensée de Bergson (1904) et sa portée philosophique”, p. 155-6.
} 
metafísicas nada mais que problemas mal colocados, pseudo-problemas. Ao fim e ao cabo, a hipótese de um paralelismo psicofisiológico é fruto de um erro de raciocínio, consequência das nossas condições de conhecimento, as quais são por ela reveladas. Ou seja, sendo uma ilusão (oscilação, prestidigitação ou escamoteação), ela não define o conhecimento filosófico, mas pode revelar que há algo que o atrapalha, uma tendência ou modo de conhecimento inadequado para a filosofia, ou para a metafísica mais especificamente. Assim, apesar da afinidade entre a crítica bergsoniana e a concepção de Kant, na crítica dos raciocínios dialéticos da razão pura, os paralogismos denunciados não vão exatamente na mesma direção ou não têm exatamente a mesma intenção. A esse respeito, pomo-nos novamente de acordo com Worms, em cujo texto supracitado lemos: “enquanto para Kant os 'paralogismos' da psicologia racional pertencem à ilusão transcendental que afeta a razão como tal, e de modo universal, os paralogismos da psicologia experimental, que Bergson, por sua vez, vem denunciar, afetam apenas uma razão científica ou filosófica, mesmo que aqui também de maneira quase inevitável”70. A dupla contradição do paralelismo psicofisiológico apóia-se no fato de que os dois sistemas de notação conciliados são essencialmente simbólicos e, portanto, não podem atingir as coisas em si - internamente -, mas somente por fora - os fenômenos. Mas, enquanto essa “ilusão transcendental” interdita, para Kant, o conhecimento metafísico, ao demonstrar que a coisa em si é incognoscível ou inapreensível, a ilusão filosófica denunciada por Bergson não afeta a metafísica, porém demonstra que o conhecimento analítico não pode atingir o em si. O sistema idealista, que supõe um espaço e objetos separados - isola os objetos na representação -, é definido como o ponto de vista do conhecimento científico. Quanto ao sistema realista, o problema está em seu modus operandi, pois o que se pretende apreender nesse caso é necessariamente inapreensível pelos procedimentos do conhecimento científico, o que o faz deslizar para o sistema de notação oposto sempre que pretende falar da realidade material da qual parte. Os sistemas de notação definem-se pela representação espacial - condição e efeito dos símbolos -, o que significa que, para ultrapassá-la, é necessário um pensamento que não pretenda conhecer isoladamente as coisas (como o cérebro, por exemplo), mas que vise interna e diretamente o todo da matéria, o que é possível somente por uma intuição da duração, tal como lemos no texto “Introdução à metafísica”, ao qual voltaremos no próximo capítulo. Ao realismo epifenomenista, cartesiano ou espinosista do espaço (os três tipos mencionados direta ou indiretamente no texto), Bergson opõe um realismo da duração, o qual não é incompatível com um idealismo do conhecimento científico e espacial. Nos textos sobre a diferença metódica entre ciência e filosofia, vemos (e veremos mais adiante) que ambos comungam

${ }^{70}$ WORMS, F. “Le paralogisme du parallélisme: Le Cerveau et la pensée de Bergson (1904) et sa portée 
a mesma realidade, mas a conhecem de distintos modos: intuitivamente e analiticamente, porque ela é tensão e extensão. Considerações estas que se desdobram da crítica efetuada no texto. Ocorre que, mesmo conduzindo o exame num plano estritamente lógico, ela extravasa para os planos psicológico e metafísico, uma vez que o filósofo denuncia a confusão inconsciente entre os diferentes sistemas, que é uma consequência da mistura dos domínios científico e metafísico. A filosofia de Bergson funda-se, antes de tudo, na crítica de tais confusões (mistos mal analisados, na linguagem de Deleuze) e na distinção das diferentes dimensões do real e seu conhecimento.

Ao concluir o exame lógico, explicitando a prestidigitação inconsciente do espírito presente na tese do paralelismo, Bergson menciona quatro "ilusões complementares que reforçam a ilusão fundamental”. Elas mostram, no seu entender, o que subjaz na metafísica herdada do cartesianismo e mantida na contemporaneidade. São "idéias simpáticas à tese do paralelismo, que se reúnem em torno dela e a defendem” (E.S., p. 207). Primeiramente, ele denuncia a idéia de uma "alma cerebral, ou seja, de uma concentração da representação na substância cortical”, o que não pode deixar de nos remeter à "glândula pineal” de Descartes. A segunda idéia é a de que "toda causalidade é mecânica e nada há no universo que não seja calculável matematicamente” (E.S., p. 207), o que envia diretamente à crítica ao determinismo e ao problema da liberdade. A terceira idéia é a de que, "para passar do ponto de vista (idealista) da representação ao ponto de vista (realista) da coisa em si, basta substituir a nossa representação imaginada e pitoresca por essa mesma representação reduzida a um desenho sem cor e às relações matemáticas dessas partes entre elas” (E.S., p. 208). E a quarta, por fim, afirma a essência do paralelismo ao dizer que, "se dois todos são solidários, cada parte de um é solidário de uma parte determinada do outro” (E.S., p. 209). As quatro se encontram, explícita ou implicitamente, na crítica genealógica do paralelismo, realizada no curso sobre a "História das teorias da memória” poucos meses antes da conferência sobre "O paralogismo do paralelismo”, e que revela o paralelismo espinosista como o mais rigoroso, o centro para o qual todos os cartesianos convergem, e que melhor realiza, portanto, tudo o que essas idéias simpáticas defendem. A elas, e a todas que elas implicam, a "tese do paralelismo dá o som fundamental” (E.S., p. 210). Ainda que não seja único, o som espinosista é, certamente, o mais vigoroso. Ao final do texto, Bergson manifesta o seu propósito ao escrevê-lo e evidencia a importância da desmontagem crítica do paralelismo no conjunto de sua obra até então publicada:

Procuramos apenas, no presente estudo, destacar a contradição inerente à própria tese. Precisamente porque as consequências a que ela conduz e os

philosophique”, p. 144 (grifos nossos). 
postulados que ela encerra recobrem, por assim dizer, todo o domínio da filosofia, pareceu-nos que este exame crítico se impunha, e que ele poderia servir de ponto de partida para uma teoria do espírito, considerado em suas relações com o determinismo da natureza (E.S., p. 210).

Numa espécie de reviravolta, a tese encontrada e laboriosamente criticada passa a ser o ponto de partida para a obra que justamente apresentara o "problema da liberdade" como centro de suas preocupações a partir de uma discussão com o determinismo e seus adversários. A teoria do espírito bergsoniana visa, pela dissolução do problema, a tornar legítima e efetiva uma metafísica da liberdade. Ora, esta era a intenção declarada pelo filósofo logo nas primeiras linhas do Ensaio, as quais citamos no início deste capítulo. Ao refutar o determinismo físico - pela extensão das leis físicas aos fenômenos psicológicos e pela universalidade física sobre a qual o mecanicismo científico se apóia - e o determinismo psíquico - pelo fato de tomar os diversos estados pelos nomes que os exprimem, como se fossem coisas, retendo apenas o aspecto impessoal, e justapondo-os “indefinidamente sem obter outra coisa que um eu fantasma, sombra do eu se projetando no espaço" (E., p. 124) -, Bergson demonstra que, ao contrário, se os estados psicológicos forem tomados com a sua coloração particular, não há necessidade de associar vários fatos de consciência para reconstituir a pessoa: “ela está inteiramente em um só dentre eles, desde que se saiba escolher. $E$ a manifestação exterior desse estado interno será precisamente o que se chama um ato livre, já que apenas o eu será seu autor - ela exprimirá o eu inteiro” (E., p. 124; grifo nosso). Esperamos ter mostrado que, em qualquer de suas versões, o determinismo científico é remetido ao paralelismo, sobretudo espinosista, e pensamos que é de sua refutação que depende a dissolução do problema para que a liberdade permaneça, enquanto duração, e seja encontrada, pela intuição própria ao método bergsoniano ${ }^{71}$.

\footnotetext{
${ }^{71}$ Num texto intitulado “O cérebro e o pensamento” (1980), Georges Canguilhem discute, numa perspectiva diferente da bergsoniana, mas não sem relação com ela, o que é patente inclusive pelo título do mesmo, as bases sustentadoras e os interesses contemporâneos na manutenção da idéia de um substrato físico (cerebral) para as qualidades morais e para os poderes intelectuais. A reconstituição dessa relação é feita de modo a apontar as questões mais recentes a respeito desse tema tendo em vista as novidades da informática. De acordo com o autor, “o computador é, com efeito, uma tentativa de imitar, graças à eletrônica do século XIX, as propriedades já reconhecidas ao cérebro pela neurofisiologia do século XIX [...]” (Georges Canguilhem. Philosophe, historien dês sciences. Paris: Éditions Albin Michel, 1993; p. 19). Assim, o computador será considerado como um cérebro e vice-versa, o que pode ser constatado pelos termos usados para designar o primeiro: cérebro consciente, máquina consciente, cérebro artificial ou inteligência artificial. No seu entender, tais conjunções incompatíveis, metáforas oriundas do meio científico, ecoaram nos meios publicitários na fase industrial da informática. E é o processo ideológico por trás dessa transferência de sentido que o autor denuncia - uma vez que o nosso cérebro é considerado um computador, o que teríamos contra este último? Para Canguilhem, um “modelo de pesquisa científica foi convertido em máquina de propaganda ideológica com dupla finalidade: prevenir ou desarmar a oposição contra a invasão de um meio de regulação automatizada de relações sociais; dissimular a presença de pessoas que decidem por trás do anonimato da máquina” (ibidem, p. 21). A recusa filosófica de reconhecer na máquina capacidades próprias ao ser vivo, referentes à criação e à vontade, será algo
} 


\section{Capítulo 2 - Contra o "nada” e o espinosismo: a plenitude afetiva do conhecimento sub specie}

durationis

No quarto e último capítulo de A Evolução criadora, antes do "lance de olhos” dirigido à história dos sistemas filosóficos, Bergson examina duas ilusões teóricas que compõem o fundo de nossa especulação sobre a natureza do real, impedindo-nos de ver a verdadeira evolução e o devir radical, a saber: a ilusão da imobilidade como anterior ou superior à mobilidade, e a ilusão do nada como anterior e inferior ao ser, que deve vencê-lo para que a existência se ponha e se justifique. Examiná-las significará revelar o que elas ocultam e, ao mesmo tempo, desemaranhar o conhecimento das teias que o impedem de alcançar efetivamente a realidade, constituindo, portanto, um empreendimento crítico tanto no que se refere ao ser quanto ao conhecer, ontológico e epistemológico. A elas, outras ilusões se mesclam, tais como a ilusão da desordem, suposta como

questionado pelos que detêm algum tipo de interesse nessa automatização pela informática, cabendo à filosofia o seu questionamento. Isto porque "em uma sociedade conservadora ou repressiva, a equação pensamento = cérebro serve de justificação às técnicas de normalização da conduta” (ibidem, p. 25). Esse texto repõe a crítica de Bergson sobre outro plano, isto é, ele reafirma a condenação bergsoniana da equivalência entre cérebro e pensamento, a qual visava, em primeira instância, à liberdade humana, a partir de uma perspectiva mais voltada para a discussão ética dessa correspondência (o que também pode ser desdobrado da crítica de Bergson), mostrando também a sua atualidade ou importância para o desmonte da versão mais recente da tese paralelista. A crítica de Bergson é uma posição contraideológica uma vez que desfaz as confusões (circularidade entre ciência e metafísica) que podem sustentar um discurso determinista (que faz da ação humana algo determinado) pela ignorância das suas origens (um saber que não se sabe: "a pior maneira de ser metafísico é sê-lo sem sabê-lo”). Cabe, por fim, ressaltar que, ao finalizar o texto, Canguilhem menciona Espinosa como exemplo de postura filosófica em prol da liberdade de pensamento e expressão, e como autor em cuja obra a liberdade é a "finalidade” máxima. Ele relata brevemente a atitude do filósofo holandês no momento em que Jean de Witt, Grande Pensionário da Holanda, com quem ele partilhava as convicções republicanas, é assassinado pelos defensores da Casa de Orange, o que o leva a escrever um cartaz com as palavras "Ultimi barbarorum” e quase afixá-lo (é detido de modo contundente pelo proprietário da casa onde morava). E acrescenta que: "Sua conduta é a prova de que, segundo a última parte da Ética, a ordem e a conexão das afecções do corpo se regula pela ordem e encadeamento dos pensamentos na alma, correspondência cuja perfeição seria a verdadeira liberdade” (ibidem, p. 32). É interessante que, ao citar a liberdade espinosana no final desse texto, Canguilhem faça menção não à proposição II, P7, origem de toda a acusação de paralelismo em Espinosa, mas à sua reformulação na primeira proposição da parte V da Ética (essa questão será tratada no último capítulo desta tese). Enfim, vale citarmos as últimas palavras do texto, pois com elas podemos ter a idéia também de uma atualização da filosofia espinosana a partir desse tema (a relação entre "O cérebro e o pensamento”) ao qual nos dedicamos na obra bergsoniana: “À primeira vista, poder-se-ia pensar que Espinosa cometeu um erro: o de acreditar que os bárbaros que ele denunciava publicamente eram os últimos. Mas, ele sabia latim e quis dizer: os mais recentes, os novos. Por conseguinte, os filósofos de hoje, qualquer que seja sua linha de pesquisa, espinosista ou cartesiana, podem estar assegurados de que não faltam ocasiões ou razões para ir, por seu próprio risco, em um gesto de compromisso controlado por seu cérebro, inscrever nos muros, cercas ou clausuras: Ultimi barbarorum” (ibidem, p. 32). É que, "esse homem [Espinosa] saiu de casa com seu cérebro, e de modo conforme à sua filosofia”, na qual não se tratava nem de negar o papel do cérebro (e sim de mostrar que "não conhecemos todas as capacidades do corpo humano e que erramos em atribuí-las, às vezes, à alma”), nem de determinar o pensamento pelo cérebro. Trata-se de uma relação original entre cérebro e pensamento, assim como de uma conduta exemplar. 
anterior à ordem, e a do possível, imaginado como anterior à realidade. Essas últimas são também invocadas no capítulo mencionado por fazerem parte de uma mesma rede de pseudo-problemas, nos quais a filosofia se enreda e se perde. A ilusão da desordem, concernente diretamente às teorias do conhecimento, é invocada após ter sido detidamente abordada no terceiro capítulo da obra citada, de modo que a ela nos reportaremos quando tratarmos da crítica genética da inteligência, também empreendida no mesmo capítulo. A análise do possível, por sua vez, é essencial para a crítica das filosofias que "venceram o nada” porque trataram a realidade de acordo com as exigências da matemática. Esta crítica está no horizonte da análise do nada, e a ela nos dedicaremos em momento oportuno, centrando-nos, sobretudo, em um curso no qual a filosofia espinosista é explicada como realização do cartesianismo e da tendência geometrizante do entendimento humano às voltas com a necessidade do Ser em sua unidade, imobilidade e eternidade. Todas essas ilusões são tematizadas e retomadas ao longo da obra de Bergson, sendo novamente problematizadas no livro O pensamento $e$ o movente, que reúne, como sabemos, os textos que tratam do método filosófico, o que faz dele referência insuprimível à nossa análise. Seguiremos o percurso da crítica da idéia do Nada para, aos poucos e também com o aporte de outros textos, mostrarmos que a nova metafísica, almejada por Bergson, tem no espinosismo um de seus principais adversários.

Das duas ilusões com e contra as quais tem início o último capítulo d'A Evolução, a primeira protege-nos (ilusoriamente, é claro) da instabilidade e do movimento inerente às coisas e ao mundo, porque nos mantém na crença de uma estabilidade e de uma imobilidade constituintes das coisas e do mundo em sua totalidade, fazendo-nos “crer que se pode pensar o instável por intermediário do estável, o movente pelo imóvel” (E.C., p. 273. Ela estivera desde o início presente nas inquietações do filósofo, cujo ponto de partida ou emancipação filosófica fora justamente a constatação da supressão do tempo real nas preocupações dos que se dedicaram ao conhecimento, tanto filosófico quanto científico. Tal ilusão fora responsável pelos equívocos nos quais as teorias do conhecimento incorreram por não diferenciarem o conhecimento espacial do temporal - confusão que está por trás de todos os erros filosóficos. Com ela, o conhecimento científico, embora se constituísse enquanto tal, porque não cabia a ele a distinção nodal entre o que pode ser medido e o que não pode - a ciência se refere, antes de mais nada, ao espaço e à matéria -, também fora prejudicado, pois mantivera como fundo insuspeito, e inconsciente, a indistinção dos domínios que caberia à filosofia diferenciar $^{72}$.

$72 \mathrm{O}$ associacionismo, por exemplo, equivoca-se ao estender para o todo da vida psíquica um tipo de conhecimento que é válido para uma parte dela, o eu superficial. E, se ele se sente certo nessa extrapolação, tal se deve, como vimos no primeiro capítulo, à tese metafísica que lhe fornece a segurança de que carece e que lhe é também confortável manter. 
A segunda ilusão consiste em ir do vazio ao pleno, da ausência à presença, do nada ao ser. Ou melhor, ela se refere à afirmação do vazio, da ausência, do nada. "Desde o primeiro despertar da reflexão, é ela que impulsiona para frente, sob o olhar da consciência, os problemas angustiantes, as questões que não podemos fixar sem sermos tomados de vertigem” (E.C., p. 275). Ela é a mais primitiva de todas as ilusões do conhecimento, pois mal começamos a pensar e perguntamos por que o mundo existe e por que nós mesmos existimos. A existência se apresenta como uma conquista sobre o nada. Ambas as ilusões, juntamente com as outras que lhes são parentes (a da desordem e a do possível), são denunciadas ao longo da obra de Bergson a partir do exame de suas consequências $^{73}$, cabendo ao texto d'A Evolução o seu questionamento no nível dos princípios, tal como o filósofo afirma logo nas primeiras linhas do último capítulo dessa obra. A verificação pela experiência das insuficiências e dos erros das teorias paralelistas, mecanicistas e finalistas revelara a metafísica oculta e inaceitável por trás daquelas concepções, que não tinham respaldo na experiência, tornando necessária uma regressão metódica aos princípios, ou seja: faz-se necessário um questionamento direto dessa metafísica, que fora revelada em diversos momentos da obra, criticada e rejeitada, mas não tematizada em si mesma.

Uma vez mais é exposta a ilusão fundamental do nosso entendimento, da qual as outras anteriormente apontadas originam-se: a transposição para a especulação dos procedimentos feitos para a prática. Contudo, para que a razão do erro ou ilusão possa ser definitivamente encontrada, é "preciso que o olhemos de frente, nele mesmo, na concepção radicalmente falsa que ele implica da negação, do vazio, do nada”, a qual é “a mola secreta, o motor invisível do pensamento filosófico” (E.C., p. 275). É preciso dissipar o mistério que sustenta as concepções metafísicas, abrindo caminho para uma filosofia que vê na duração o tecido de que é feita a realidade. O mistério advém da sobreposição do ser ao nada e da crença de que na representação do nada há menos do que na de alguma coisa. Para Bergson, “o desdém da metafísica por toda realidade que dura vem precisamente de que ela chega ao ser passando pelo 'nada' e de que uma existência que dura não lhe parece suficientemente forte para vencer a inexistência e colocar-se a si mesma” (E.C., p. 276). A metafísica se inclinará, assim, a dotar o ser de uma existência lógica, a única capaz de se sobrepor ao nada. Com isso, pretende-se que o mistério da existência se dissipe, mas o que ocorre é a dissimulação da existência física e psíquica, de tudo o que se dá na experiência vivida e sentida. Com a crítica da idéia do Nada, uma nova metafísica se revelará, tanto aberta quanto positiva.

A família das ilusões apontadas acima se sustenta em um "movimento retrógrado do

73 Como vimos em relação à análise das relações entre corpo e alma, desenvolvida a partir da denúncia da projeção 
verdadeiro", de acordo com o qual se vai do menos ao mais ${ }^{74}$, criando problemas inexistentes a partir da retroprojeção de uma imagem do ser, da ordem e do existente, em um nada, uma desordem e um possível prévios. De todas as ilusões, a do nada é anterior ou mais primitiva, sendo que a ilusão do estável ou do imóvel, por exemplo, se estabelece no fundo sobre a idéia de que haveria menos ser no móvel do que no imóvel. Ora, o predomínio do imóvel levou, na modernidade, às doutrinas que tentaram reconstituir a relação entre o corpo e a mente a partir da cisão estabelecida por Descartes, desembocando no paralelismo como tradução de um mesmo original, e, delas, a mais radical, como vimos, era a espinosista. Também no que se refere à crítica do nada (ou à mola secreta de toda a atividade filosófica tradicional), o espinosismo será prioritariamente combatido por Bergson. Na defesa do conhecimento sub specie durationis, o filósofo precisa enfrentar aquele que, no seu entender, mais radicalmente afirmara o ser enquanto existência lógica, assim como defendera o conhecimento sub specie aeternitatis.

No percurso demonstrativo da ilusão da ausência, no qual é analisado "em que pensamos quando falamos do nada”, as outras ilusões se mesclarão, constituindo não somente uma família, como um amálgama que girará em torno do mesmo vazio, mostrando uma espécie de metamorfose de uma a outra, numa circularidade que revela tanto as dificuldades intrínsecas ao nosso modo usual de conhecer quanto a redundante queda na mesma problemática: a superação do Nada pela posição de um Ser que lhe seja simetricamente oposto. Se pensamos em algo ao falarmos do nada, trata-se de desvendar em que consiste essa experiência do pensamento, e se se trata de uma experiência do pensamento apenas. Para além do que é dito, importa encontrar ou desnudar o que é experimentado pela consciência, para saber qual a origem do vocabulário do negativo ${ }^{75}$.

Num primeiro momento, o percurso da crítica parte da constatação de que a representação do nada consiste em imaginá-lo ou em concebê-lo, sendo necessário, portanto, analisar se há uma imagem ou uma idéia que lhe diga respeito. No exame da imagem, vemos, com Bergson, o mundo externo desaparecer "no silêncio e na noite”, a partir da suposição de um desligamento gradual de todas as nossas percepções. Com o desaparecimento do mundo, resta, no entanto, ainda que seja em

do plano físico para o psíquico nas concepções paralelistas e epifenomenistas.

74Trata-se da idéia de que há menos na desordem do que na ordem, menos no possível do que no real, e assim por diante. Bergson demonstra que ocorre o contrário, uma vez que, por exemplo, há na desordem, além de uma ordem encontrada, e não desejada, a sua negação - há mais e não menos. A esse respeito, conferir o primeiro capítulo do livro de Gilles Deleuze, Bergsonismo, no qual a questão dos falsos problemas ("problemas inexistentes", assim definidos pela confusão entre o mais e o menos que seus termos implicam, e dos "problemas mal colocados", cujos termos representariam mistos mal analisados) é detidamente tratada.

75A esse respeito, conferir o livro do professor Bento Prado Júnior, Bergson: presença e campo transcendental, cujo primeiro capítulo, “A miragem da ausência”, é dedicado à crítica da idéia do Nada e seus desdobramentos, motivo pelo qual ele muito nos auxiliara em nossa própria leitura e tentativa de reconstrução da referida crítica, apesar das 
última instância, a consciência do corpo próprio reduzido ao presente. Ao tentar reduzir também essa consciência, atenuando as sensações do próprio corpo e da lembrança do passado, outra consciência surge, testemunha desse desaparecimento. “Assim, não importa o que eu faça, percebo sempre alguma coisa, seja de fora, seja de dentro” (E.C., p. 278). A imaginação não pode abarcar a totalidade, eliminando o mundo e a consciência, o que faz dela algo sempre parcial. O pensamento jamais forma a imagem de uma supressão de tudo e o esforço para criar essa imagem consegue apenas uma oscilação entre a visão de uma realidade exterior e a de uma realidade interna. Indo de uma a outra, há um ponto no qual ainda não percebemos um dos dois termos, e já não percebemos o outro, é nele que se forma a imagem do nada. Mas, em realidade,

percebemos, então, a ambos, tendo chegado ao ponto em que os dois termos são contíguos, e a imagem do nada, assim definida, é uma imagem repleta de coisas, uma imagem que encerra ao mesmo tempo a do sujeito e a do objeto, com, em acréscimo, um salto perpétuo de uma à outra e a recusa de nunca pousar definitivamente em uma delas (E.C., p. 279).

A análise da imagem nos mostra que não podemos opor esse Nada, tal qual se dá na imaginação, ao Ser, uma vez que ele é sempre parcial e posterior, fruto de uma consciência que não consegue se fixar em um conteúdo positivo, saltando de um a outro, numa errância inconsciente e, mesmo, inconsequente.

Ao ser lançada a imaginação do negativo no descrédito de sua parcialidade, a voz defensora da filosofia tradicional de pronto estabelece que os raciocínios filosóficos não se fazem sob a forma de imagens, e sim de idéias. Ela pretende que o pensamento conceitual se coloca fora da imaginação errante. Desse modo, admite que não podemos imaginar uma abolição de tudo, mas afirma que podemos concebê-la. A análise da ilusão do nada é uma crítica da filosofia tradicional - construída a partir da utilização teórica do negativo - o que exige uma desconstrução por dentro de sua própria argumentação, mostrando a impossibilidade de tal uso. Assim, o exame da idéia do Nada se inicia com a invocação de Descartes e de sua afirmação, na Sexta Meditação, de que, embora não possamos imaginar um polígono de mil lados (quiliógono), podemos concebê-lo pelo pensamento. O mesmo valeria para a abolição de todas as coisas. Para tanto, bastaria que partíssemos da abolição de qualquer objeto de nossa experiência e a estendêssemos a um segundo, depois a um terceiro e, assim, sucessivamente, de modo que o nada seria o limite ao qual tenderia a operação: ele é a abolição de tudo. Para Bergson, essa tese é absurda porque implica uma contradição posta em seus próprios

diferenças entre nossos interesses. 
termos: pretende-se chegar à abolição do Todo por uma operação cujo mecanismo se efetua sobre uma parte. O que se pretende é, pois, estender tal operação parcial à totalidade das coisas. E mais. A abolição de algo, nessa operação, significa a consideração de um lugar vago, mas se a hipótese supõe um "lugar”, este é “um vazio limitado por contornos precisos, ou seja, uma espécie de coisa” (E.C., p. 281). O objeto, do qual se parte, deixa seu próprio vazio (não está mais lá), o que não significa que se criou um vazio na natureza - outro objeto tomou o seu lugar (ainda que seja apenas o ar), uma vez que “não há vazio absoluto na natureza”. É no seio da racionalização da imaginação que se evidencia o caráter extra-intelectual da negação, pois,

\begin{abstract}
Um ser que não fosse dotado de memória ou de previsão nunca pronunciaria as palavras "vazio" ou "nada”, exprimiria simplesmente o que é e o que percebe; ora, o que é e o que se percebe é a presença de uma coisa ou de outra, nunca a ausência do que quer que seja. Só há ausência para um ser capaz de lembrança e de expectativa. Ele se lembrava de um objeto e espera talvez reencontrá-lo: encontra outro e exprime a decepção de sua expectativa, nascida ela própria da lembrança, dizendo que não encontra mais nada, que se depara com o nada (E.C., p. 281).
\end{abstract}

A experiência do pensamento às voltas com a ausência é uma experiência afetiva, de expectativa, falta do que se espera e decepção. Palavras que devem compor o vocabulário do negativo. Sentimentos que colorem o nosso pensamento quando nos deparamos com algo novo no lugar do antigo. A idéia de abolição "implica, do lado subjetivo, uma preferência, do lado objetivo, uma substituição, sendo apenas uma combinação ou, de preferência, uma interferência, entre esse sentimento de preferência e essa idéia de substituição” (E.C., p. 282). Trata-se de uma idéia complexa: constituída por uma subjetividade afetiva, plena de expectativas e preferências, e por uma objetividade também plena, já que, não havendo nunca vazio, fenda ou brecha no mundo - fora ou dentro de nós -, o que há é o fluxo contínuo da duração. Podemos dizer que "não há falta na

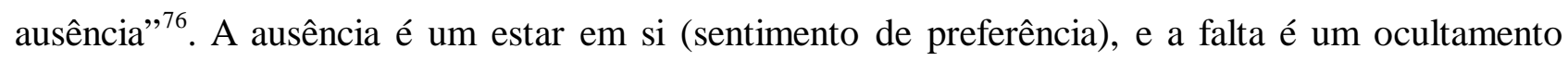
dessa e de outras presenças por um sujeito apegado a si - às suas preferências - a ponto de não ver ou não querer ver a substituição do objeto de seu desejo. Ele vive da lembrança do passado na tentativa decepcionante de reviver aquela presença. Poderia ser a falta do não vivido? O que teria sido a sua vivência? O futuro do pretérito é também uma das marcas do negativo, instituindo uma temporalidade que é pura expectativa, suposição de um possível contrastante com o atual. Assim, do nada advém uma constelação de decepções e desconsolos. Mas, se ele apresenta tal face negativa,

76Carlos Drummond de Andrade, “Ausência”. 
podemos dizer que também manifesta uma positividade: indica a valorização de alguma coisa. Um sujeito que não sentisse falta de nada seria um sujeito sem lembranças ou sem preferências, alguém que vagaria ao sabor de um presente infindável, num dissabor irremediável, posto que nenhum encontro permaneceria no horizonte de suas preferências inexistentes. Um sujeito que nada valorizaria, o que indica uma falta desumana.

Evidencia-se aqui, no seio da discussão com os defensores do nada ideal, concebido pelo pensamento conceitual, uma característica fundamental da inteligência humana: seu caráter extraintelectual, por mais paradoxal que possa parecer, pois, como lemos na sequência do texto, "uma inteligência que fosse apenas inteligência, que não sentisse falta ou desejo, que regrasse seu movimento pelo movimento de seu objeto, sequer conceberia uma ausência ou um vazio” (E.C., p. 282). Ora, o terceiro capítulo de A Evolução criadora mostrara, pela crítica genética, da qual trataremos mais adiante, que a inteligência é marcada por sua vocação prática. E, na prática, deparamos constantemente com aquilo de que não carecemos, que não queremos, sendo definida a ação humana como algo que visa sempre a preencher esses vazios em nossa volta. A inteligência, cuja vocação não é teórica, permanecendo nesse registro originário, faz o mesmo ao lidar com as questões teóricas. Assim, podemos dizer que o problema não está em sua vocação primeira, mas em seu uso inadequado. Se é positivo que sintamos falta, instituindo valores pelos quais agimos, negativo é forçar a inteligência, dentro de sua tendência natural, para um conhecimento de outro domínio. É preciso inverter a tendência da inteligência, violentá-la, e só assim poderemos ter um conhecimento filosófico adequado, isto é, intuitivo. Talvez, possamos dizer: é preciso buscar outra prática teórica. Por fim, a representação do vazio é plena e positiva porque ela "se resolve, pela análise, em dois elementos positivos: a idéia, distinta ou confusa, de uma substituição, e o sentimento, experimentado ou imaginado, de um desejo ou de uma falta” (E.C., p. 283). Sem nos darmos conta de tal complexidade, permaneceremos atrelados a um dos lados da realidade, o qual tem sua importância - e também voltaremos a ela posteriormente -, mas que não dá conta do todo ou do processo criativo e livre pelo qual a vida se constituiu e nos constituiu, como sujeitos também criativos e livres - e isto não apesar da inteligência, ainda que seja, de certo modo, contra ela.

Dessa dupla análise resulta, segundo o filósofo, que a idéia do nada absoluto, entendido como uma abolição de tudo, é uma pseudo-idéia ou uma simples palavra. Ainda mais: é uma idéia que, ao ser analisada, destrói-se ou se revela impensável. Ora, se a representação do negativo não esvazia o mundo, mas, ao contrário, o preenche, pois cada abolição é substituição, dando 
"nascimento - como que 'às suas costas' - a uma afirmação simétrica"77, então, em lugar de uma negação de tudo, de um Nada absoluto, o que vemos surgir é uma plenitude afirmativa, ou a descrição do real em sua amplidão e riqueza - em toda sua presença. Se a idéia do quiliógono é algo que podemos conceber, em detrimento da imaginação, da qual não pode formar a imagem, o Nada absoluto é irrepresentável tanto no nível da imaginação quanto no nível do conceito - é tão impensável como um círculo quadrado.

“Mas, a ilusão é tenaz” (E.C., p. 283). E Bergson passa, em seguida, à análise de seu novo avatar: a idéia de que a negação pode ser pensada sem que se represente uma abolição ou substituição, as quais seriam, ainda, operações físicas. Se a representação de uma supressão se liga à de um fenômeno que tem uma localização espaço-temporal, então, ela ainda implicaria a evocação de uma imagem, o que significa que é preciso "libertar-se da imaginação para recorrer ao entendimento puro” (E.C., p. 284). Para tanto, bastaria que, por um esforço de abstração, um objeto qualquer fosse pensado separadamente e, em seguida, por uma penada intelectual, fosse "riscado do mapa”: considerado inexistente pelo acréscimo de um sinal negativo. Novamente, o que será evidenciado aqui é a afirmação de tudo, da realidade, sob a suposta crença em uma operação que pudesse ser isolada do restante das coisas. A própria operação parte da afirmação de uma existência para, então, excluí-la por uma causa que a suplanta ${ }^{78}$. Mas, a causa, mesmo implícita, está presente ao espírito, e é dele inseparável, o que significa que o "ato pelo qual se declara um objeto irreal coloca, portanto, a existência do real em geral” (E.C., p. 285). Considerar um objeto como irreal não o priva de toda e qualquer espécie de existência, significando simplesmente que a existência à qual o prendemos, e que é inseparável de sua representação, é uma existência ideal ou possível. É sempre da existência que se parte, e o que se tem é a afirmação do real mais um ato do espírito que o expulsa. Isto mostra, de acordo com a fórmula bergsoniana já mencionada, que...

há mais e não menos na idéia de um objeto concebido como "não existente" do que na idéia de um objeto concebido como "existente", pois a idéia do objeto "não existente" é necessariamente a idéia do objeto "existente" com, em acréscimo, a representação de uma exclusão desse objeto pela realidade atual tomada em bloco (E.C., p. 286).

Por trás de todas essas operações, fica exposta não só a impossibilidade de uma afirmação do

77Prado, Bento F. J., Presença e campo transcendental, p. 83.

78Para Bergson, a representação da existência de um objeto é inseparável da representação do objeto, sendo uma mesma coisa, portanto, pensar um objeto e pensá-lo existente, o que, nas suas palavras, Kant trouxe "à plena luz em sua crítica do argumento ontológico” (E.C., p. 284). A esse respeito, conferir o livro de Bento Prado, p. 57-58. 
nada em si mesmo, como a sua constante referência aos objetos da experiência, sejam eles quais forem, coisas ou estados de consciência. Bergson chega, desse modo, ao ápice da crítica da idéia do Nada: a argumentação segundo a qual a negação é uma operação puramente lógica, sem referência ao mundo dos objetos. Esse novo e final momento do percurso crítico se inicia com a declaração de que a representação do inexistente, tal como fora exposta, poderia ser considerada como algo ainda não suficientemente livre de todo elemento imaginativo, sendo insuficientemente negativa. Para encontrar a negação “rigorosa”, seria necessário, de acordo com a tradição filosófica na perspectiva bergsoniana, considerar a inexistência como uma operação completamente intelectual e a negação como algo inteiramente ideal, constituída tão somente pelos atos do espírito em uma esfera puramente lógica - "uma operação inteiramente intelectual, independente do que se passa fora do espírito” (E.C., p. 286). Trata-se da idéia de que qualquer coisa pode ser abolida idealmente pela aposição de um “não” que decreta essa abolição, de modo que possa ser pensada inexistente. Esse momento da crítica é fundamental porque é nele que a análise colocará em relevo os erros inerentes ao pensamento do negativo - oriundo do mecanismo cinematográfico do nosso entendimento desmantelando a argumentação lógica que lhe dá sustentação e, desse modo, permitindo que o pensamento, não tendo que optar entre o Ser e o Nada, possa captar a duração. O filósofo, nessa etapa da crítica, aclara e desenvolve o motivo pelo qual o Ser foi dotado de uma existência lógica, tal como exposto no início, de modo que, com ela, reencontramos as doutrinas que assim o conceberam, sendo que, dentre elas, a mais radical é a espinosista.

Todas as dificuldades e todos os erros, aqui, provêm da suposição de um pretenso poder inerente à negação: "Representa-se a negação como exatamente simétrica da afirmação. Imagina-se que a negação, como a afirmação, baste-se a si própria” (E.C., p. 286; grifo nosso). Pelo vocabulário que Bergson utiliza, já sabemos que não se trata de uma “operação puramente intelectual”, e sim, digamos, de uma nova queda na imaginação, o que não é estranho, pois se trata da mesma ilusão, e toda a análise crítica expõe esse procedimento que lhe é inerente, seja explicitamente, num primeiro momento, quando se parte das imagens propriamente ditas, seja implicitamente, nas etapas seguintes, nas quais a imaginação é dissimulada sobre um suposto fundo de pensamento conceitual ou lógico. Em qualquer de suas versões, a ilusão do nada é sempre imaginativa. E isto porque só “a afirmação é um ato completo do espírito, podendo chegar a constituir uma idéia, a negação não é nunca mais que a metade de um ato intelectual, do qual nós subentendemos ou antes remetemos a outra metade a um futuro indeterminado” (E.C., p. 287). Esta indeterminação impede que ela aspire à mesma condição que a afirmação, pois, enquanto a afirmação determina algo, a negação visa sempre a alguém, julga um julgamento para prevenir uma afirmação inadequada - “ela afirma algo de uma afirmação que, 
por sua vez, afirma algo de um objeto” (E.C., p. 288) -, deixando que uma afirmação futura determine o que ficou indeterminado. Eis o seu caráter prático ou extra-intelectual. Ela visa a alguém e não apenas algo, como ocorre com uma operação intelectual. Com a negação, há um “começo de sociedade”. Avisando sobre um equívoco no julgamento, sua importância é enorme, pois sua essência é “pedagógica e social” (E.C., p. 288). Vemos novamente uma positividade na negação, mas agora em relação ao futuro, assim como, antes, ela se referira ao passado. Em ambos os casos, o que se evidencia é seu caráter prático. Um sujeito que nega porque sente falta de algo é alguém que rememora, e um sujeito que nega porque sente a importância de corrigir um erro abre a perspectiva de um futuro que o corrija. Mas a positividade teórica do negativo, enquanto algo que se baste a si mesmo, é uma representação falsa e arbitrária. Tomada como uma idéia do pensamento conceitual, ela se resolve em dois elementos positivos, como vimos (a idéia de uma substituição e o sentimento de desejo ou falta), e, tomada como uma operação do entendimento, ela se mostra uma afirmação de segundo grau (afirma algo de uma afirmação). Ou seja, o Nada é sempre derivado do Ser, posterior a ele, e nele se resolve.

A positividade do Nada, à qual nos referimos anteriormente, e mesmo nas linhas anteriores, está inscrita justamente em seu caráter prático e afetivo em decorrência da índole pragmática da inteligência humana, que lhe dá origem e sustentação. Aqui, podemos dizer que há uma potência afirmativa da negação porque traduz uma potência valorativa e indefinida para a ação humana. Ela se refere a uma região da realidade na qual a lógica também se inscreve como operação refinada do entendimento humano - e isto é sumamente importante para a crítica bergsoniana da tradição filosófica como repetição do mesmo erro fundamental em consequência da nossa maneira natural de agir e pensar. O que é necessário, no entender de Bergson, é separar afirmação e negação de acordo com a realidade a que se referem e com o modo pelo qual se lhe referem. Esta separação só pode ser realizada a partir daquilo que ele considera fundamental para que a filosofia não volte a incorrer nos mesmos erros do passado (cair nas velhas antinomias, ou delas escapar pela eliminação do que as abarca, a metafísica): engendrar a inteligência, o que não quer dizer que é preciso fazê-la, e sim "vêla se fazer, deixando-a se desfazer"79. Antes de prosseguirmos na exposição da análise da idéia do nada, faz-se necessário um desvio pela crítica genética da inteligência para que possamos vislumbrar não apenas aquilo que o "nada” encobre - a duração enquanto objeto de uma nova e positiva metafísica -, mas também, e sobretudo, aquilo contra o qual a crítica do nada (ancorada na análise da inteligência) se volta: uma filosofia essencialmente lógica e metodicamente geométrica.

79 CANGUILHEM, G. “Commentaire au troisième chapitre de L'Evolution créatrice” in Annales Bergsoniennes, p. 


\section{Crítica genética da inteligência}

Nos dois primeiros capítulos d'A Evolução criadora, Bergson identifica os modos de ação da vida sobre a matéria: o torpor e a fotossíntese, no caso das plantas (capacidade sobretudo de acumular energia), o instinto e a inteligência. Estes são divididos entre os seres que se definem pela ação propriamente dita (capacidade de dispender energia) e se repartem em linhas evolutivas distintas segundo o modo com que agem, constituindo faculdades de conhecimento por envolverem a percepção determinada do objeto (matéria inerte ou outro ser vivo) que lhes é útil - no caso do instinto - e também a possibilidade de relacioná-los por esforço de abstração ou generalização - no caso da inteligência. Pertencentes a linhas evolutivas distintas, há diferença de natureza entre ambos (e não de grau), embora permaneça sempre um resquício da fonte comum a ambos, de maneira que há uma franja instintiva nos seres inteligentes (os humanos), e vice-versa ${ }^{80}$.

Produto de uma escolha da vida, ou do esforço vital no sentido de um conhecimento ilimitado e formal ${ }^{81}$, a inteligência é definida, sobretudo, por sua capacidade de estabelecer relações, ao passo que o instinto, também depositado ao longo da criação vital, caracteriza-se pela referência às coisas. Trata-se de dois conhecimentos radicalmente distintos, ainda que ambos sejam duas maneiras (ou métodos) de ação sobre a matéria bruta ${ }^{82}$ : enquanto o instinto consiste em uma faculdade natural de utilização de um mecanismo inato, a inteligência é definida como a faculdade de fabricar objetos artificiais - instrumentos que fabricam outros instrumentos, de modo a diversificar e ampliar indefinidamente a fabricação. No caso do instinto, o conhecimento é atuado e inconsciente, e no caso da inteligência, é pensando e consciente. A tendência da inteligência de estabelecer relações, entre a situação dada e os meios de utilizá-la, implica o conhecimento natural de relações gerais e o estabelecimento, também natural, de similitudes no mundo material, de modo que a ação inteligente se orienta pelo que se assemelha ou se repete. É como se a vida, nos dizeres de Bergson, não se

150.

80 Esse resíduo instintivo é importante porque permitiu, por exemplo, o nascimento da poesia ou da arte em geral, uma vez que homens não apegados à instrumentalidade da inteligência ou às necessidades da prática humana (os artistas) deram vazão a outro modo de percepção da realidade.

81 A inteligência, não se limitando a um objeto - “sendo apenas uma forma sem matéria” -, traz consigo a capacidade de ultrapassar a si mesma. O conhecimento formal da inteligência tem uma incalculável vantagem sobre o conhecimento material do instinto, a saber: uma forma, porque é vazia, pode ser preenchida por um número indefinido de coisas, até por aquelas que "não servem para nada”. Assim, “um conhecimento formal não se limita ao que é praticamente útil, embora seja em vista da utilidade que ele tenha sua aparição no mundo” (E.C., p. 152). Sobre isto, discorreremos adiante.

82 "Instinto e inteligência representam, portanto, duas soluções divergentes, igualmente elegantes, a um só e mesmo problema” (E.C., p. 144). 
contentasse em produzir organismos, e tivesse convertido a matéria inorgânica a um apêndice a ser manipulado pela indústria do ser humano. Neste sentido, a inteligência é "a vida olhando de fora, se exteriorizando em relação a si mesma, adotando em princípio, para dirigi-las de fato, as manobras da natureza inorganizada” (E.C., p. 162). Disto resulta o estranhamento da inteligência em face do vivo ou da organização vital, e sua tentativa sempre recorrente de resolver o orgânico em inorgânico, o vivente em inerte, o movimento em imobilidade; em suma, o desconhecido em conhecido. Ora, no terceiro capítulo de A Evolução criadora, Bergson empreende uma gênese da inteligência que é, ao mesmo tempo, gênese dos corpos. Ambas são correlativas, porque as linhas de nossa inteligência desenham a forma de nossa ação sobre a matéria e esta, por sua vez, se regra pelas exigências de nossa ação - "Intelectualidade e materialidade ter-se-iam constituído, no detalhe, por adaptação recíproca” (E.C., 188). Tal empreitada é, ao mesmo tempo, crítica da história da filosofia, uma vez que se pauta na denúncia do vício comum a todas as teorias filosóficas, o qual pode ser definido pela consideração de validade universal às operações intelectuais, pelo desconhecimento da ruptura entre orgânico e inorgânico - há uma diferença de natureza entre ambos, não de grau - e, assim, pela posição de uma unidade dos objetos.

A inteligência, prolongando nossos sentidos, e na tentativa dessa ampliação da percepção, elabora concepções ou constelações conceituais. Os conceitos, exteriores uns aos outros como os objetos do espaço, têm a mesma estabilidade que eles - estes são modelos para criação daqueles. À percepção das coisas, acrescenta-se a representação do ato pelo qual a inteligência as fixa. Às imagens sobrepõem-se os símbolos. Há uma comunicação entre ação e representação porque ambas derivam do caráter pragmático da inteligência, e uma pode alimentar a outra, fazendo-a se aperfeiçoar $^{83}$. A inteligência abrange tanto a técnica de manipulação da matéria quanto a ciência que pretende conhecê-la, e, para manipular os símbolos, que derivam da consideração dos sólidos, ela cria regras que traduzem as relações mais gerais dos próprios sólidos, o que significa, para Bergson, que "nossa lógica triunfa na ciência que toma a solidez dos corpos por objeto, ou seja, na geometria” (E.C., p. 162). Ambas, lógica e geometria, se engendram reciprocamente. As propriedades gerais e imediatamente percebidas dos sólidos sugerem-nos uma "geometria natural”, o que podemos constatar, segundo Bergson, pelo fato de que as questões que concernem à situação e à grandeza põem-se à nossa atividade primeiramente ${ }^{84}$, implicando uma exteriorização da inteligência em ação,

83“Uma mecânica grosseira suscita uma matemática ainda imprecisa: esta, tornando-se científica e fazendo então surgir em torno dela as outras ciências, aperfeiçoa indefinidamente a arte mecânica” (P.M., p. 84).

84“o selvagem consegue, melhor que o civilizado, avaliar as distâncias, determinar uma direção, retraçar de memória o esquema frequentemente complexo do caminho que ele percorreu e voltar, assim, em linha reta, a seu ponto de partida” (E.C., p. 213). 
antes mesmo que surja a inteligência reflexiva. Dessa geometria natural e da lógica que dela se desdobra, decorre a geometria científica, "a qual estende indefinidamente o conhecimento das propriedades exteriores dos sólidos” (E.C., p. 162). Se materialidade e intelectualidade vão na mesma direção, isto ocorre não porque a inteligência possui uma geometria latente, mas também porque a matéria é lastreada de geometria. Esta é, contudo, apenas uma de suas tendências, a que a levaria, em seu limite, a fundir-se com o espaço, de modo que seria constituída por partes externas umas às outras - partes extra partes. Embora ela se preste às operações da inteligência reflexiva que a corta ou recorta e, depois, costura -, não se finda nelas. Captar o que ela é - movimento - é algo que escapa à inteligência. A matéria se estende no espaço, ou melhor, no esquema concebido pela inteligência ${ }^{85}$, caracterizando-se pela distensão que, de todo modo, não perde a vibração constitutiva do universo ${ }^{86}$ - nosso contato com as coisas nos proporciona inumeráveis vibrações que nossa percepção condensa e unifica. Ao tentar estender o campo perceptivo, concebendo o que a percepção não pode proporcionar, a inteligência unificará os conceitos com os quais representa o mundo, a ponto de subsumi-los a um mesmo e único princípio. Ora, a percepção unifica porque, antes, abstrai e generaliza. Ela procede de modo a isolar o que a interessa, indo mais diretamente às propriedades comuns das coisas. Abstração e generalização são vividas e não pensadas, na quase totalidade dos casos, excetuando-se os seres humanos, os quais tomam consciência do poder de generalizar e passam a formular idéias gerais, conscientes e refletidas. Essa atividade não será mais algo que se inscreve no âmbito da interação do sujeito com o mundo, ela se transformará em um instrumento de conhecimento. Isto acontece porque a percepção de semelhanças, que é, antes de tudo, a propriedade que coisas ou estados possuem de obter do nosso corpo a mesma reação, fazendo-o esboçar a mesma atitude ou começar os mesmos movimentos, além de organizar o plano da nossa ação, passa a nortear também a especulação ${ }^{87}$.

A generalização não tem origem no plano do conhecimento lógico, mas no biológico. Deste àquele, há uma mudança importante, qual seja: vamos da semelhança, que caracteriza o vital, a um

85 O espaço, para Bergson, é o produto de uma concepção que atribui à extensão um termo ideal. É o âmbito da pura exterioridade de partes homogêneas, da divisão e do número. Sendo uma concepção, ele é distinto da definição kantiana, de acordo com a qual ele é uma forma pura da nossa percepção. No Ensaio, lemos que ele consiste na “concepção de um meio vazio homogênio”, e não em uma forma pura de nossa sensibilidade, como para Kant. Em Matéria e memória, o eapaço é apresentado como “esquema de uma divisibilidade indefinida”. De qualquer modo, trata-se de distiguir a "percepção da extensão”, ou seja, a apreensão concreta e qualitativa da extensão ou do conteúdo da percepção (a respectiva situação dos objetos materiais), e a concepção do espaço, que é a representação abstrata das relações quantitficáveis que tais objetos mantêm entre si.

86 Há, nela, “vibrações elementares das quais as mais curtas são uma duração muito pequena, quase esvaescente, mas não nula” (E.C., p. 302).

87 Para formar as idéias gerais, nossa reflexão “será poderosamente ajudada pela palavra, que fornecerá novamente à representação um quadro, desta vez mais espiritual que corporal, no qual se inserir” (P.M., p. 60). 
sentido mais preciso e estreito dela, a identidade. Isto porque, para Bergson, quanto mais aprofundamos a matéria, mais caminhamos na direção de elementos ou acontecimentos idênticos “resolvemos o químico em físico e o físico em matemático” (P.M., p. 62). Trata-se da identidade numérica aparecendo como horizonte da generalização. A partir de sua capacidade fabricadora, que não se exerce apenas sobre a matéria, o homem poderá formar algo como a idéia geral da idéia geral $^{88}$.

Desconsiderando (ou desconhecendo) a diferença de natureza entre orgânico e inorgânico, haverá um consenso filosófico em afirmar a unidade da natureza, representando-a sob forma abstrata ou geométrica. Como tudo o que é geométrico é acessível à inteligência humana, esta terá a função de abarcar a totalidade do real. A metafísica, regrando-se também pelo entendimento unificador, incorrerá em um círculo, pois, como Bergson acusa, ela consistirá em encontrar uma unidade que é posta de início, a priori, "uma unidade que se admite cegamente, inconscientemente, pelo simples fato de que abandonamos toda a experiência à ciência e todo o real ao entendimento puro” (E.C., p. 199). Se a simbolização é válida e necessária para a ciência, ela é nefasta para a metafísica, de modo que, não sendo possível salvá-la das armadilhas em que se envereda, ao usar os procedimentos simbólicos da inteligência para lidar com o que não pode ser simbolizado, decretar-se-á a sua morte ou o fim de suas aspirações como conhecimento seguro. Para Bergson, o que deve ser questionado é justamente esse caráter unificador do entendimento, o qual, tomado como método de conhecimento verdadeiro da realidade, se torna um absoluto, como se ele "tivesse caído do céu, com sua forma, como nascemos, cada um de nós, com nosso rosto” (E.C., p. 153). A consequência dessa absolutização da inteligência, que unifica por uma necessidade que lhe é inerente, é que todo o conhecimento torna-se relativo às suas exigências. Considerando-a, ao contrário, como relativa às necessidades da ação humana, Bergson poderá refundar a metafísica, porque o conhecimento, deixando de ser um produto da inteligência, não estará “suspenso a ela”, assim como ela mesma "se torna, em certo sentido, parte integrante da realidade” (E.C., p. 153). Mais ainda: a metafísica escapará do dilema do “Tudo ou Nada”, engendrado pela ilusão do conhecimento concernente à unidade do ser.

A crítica da inteligência permite a Bergson separar a esfera do conhecimento e a da percepção, o que significa que a inteligência não esgota a possibilidade de conhecimento, que há apenas diferença de grau entre a percepção e a inteligência e, ainda, que o conhecimento “essencial”

88 "Pode então construir idéias gerais como bem lhe aprouver. Começa naturalmente por aquelas que mais podem favorecer a vida social, ou que simplesmente se vinculam a ela; depois, virão as que interessam à especulação pura; e, por fim, as que construímos por nada, pelo prazer” (P.M., p. 67). 
não se dá pela percepção geral e usual ${ }^{89}$, uma vez que esta diz respeito ao nosso eu superficial. Os princípios ou leis dela decorrentes não poderão ser tomados como definidores da realidade ou de qualquer realidade, e sim como definidores de uma região da realidade, o mundo material ou extenso. Desse modo, Bergson havia demonstrado, anos antes d'A Evolução ${ }^{90}$, que a "origem de nossa crença no princípio de causalidade”, por exemplo, está em uma coordenação progressiva de impressões visuais com as reações motoras subsequentes. Entre uma impressão visual e uma impressão tátil, há a criação de hábitos motores e isto porque, ao acrescentarmos uma impressão tátil determinada a uma impressão visual determinada, tal operação se define por um hábito que faz parte de nossa vida de modo integrante: uma operação pela qual nosso corpo inteiro se interessa e para a qual tende a atividade fundamental de nosso sistema nervoso, a qual é, antes de tudo, sensorimotor $^{91}$. “A impressão visual sendo, então, o que chamamos de uma causa e a impressão táctil, um efeito, a atividade sensori-motora do corpo religando esse efeito a essa causa, segue-se que a relação dinâmica da causa ao efeito, a determinação necessária do efeito pela causa, são sentidas e vividas aqui, por nós, antes mesmo de serem pensadas” (M., p. 425-6). Somente o homem pode refletir sobre essa crença e é dessa reflexão que nasce a representação propriamente dita da lei de causalidade. A ciência esvaziará a causalidade dos elementos dinâmicos aos quais estava ligada e a relação de causa e efeito se aproximará da relação do princípio à consequência, de modo que a causalidade passe a implicar uma necessidade cada vez mais rigorosa e matemática. A inteligência, órgão da ação e da representação, será responsável por uma identidade entre o mecânico e o geométrico, e também entre o geométrico e o lógico, como expusemos. Assim sendo, a uma certa regularidade vivida por nós em nosso contato com o mundo, a inteligência reflexiva substitui uma repetição como passagem do mesmo ao mesmo, ou seja, como identidade. A causalidade passa a ser redutível ao princípio de identidade. O mesmo valendo para a lei de conservação de energia, a qual recusa e interdita a criação de qualquer parcela, por menor que seja, de força ou movimento no universo, o que significa que, se as coisas não se passassem mecanicamente, se uma vontade livre interviesse de modo a realizar atos livres, ela seria violada. O que está por trás desse princípio, segundo Bergson, é a tese metafísica da imutabilidade de Deus, ou seja, um dogma. Não se trata de

89 De acordo com Débora Morato Pinto, "Bergson refere-se recorrentemente à tradição filosófica como percurso que, no mesmo gesto, nega a realidade do movimento (e da mudança) e desconsidera a relevância teórica dos dados da sensibilidade, substituindo o 'percepto pelo conceito' dada a incompletude e a efemeridade do conteúdo sensível” (cf. “Crítica do negativo e virada ontológica em Bergson: a filosofia como pensamento em duração" in Crítica do negativo e pensamento em duração, Coletânea de textos do Colóquio Internacional Bergson, organizada por Débora Morato Pinto e Silene Torres Marques. São Paulo: Alameda, 2009; p. 247).

90 Tal como proferido, em 1900, na "Note sur les origines psycologiques de notre croyance a la loi de causalité” in Mélanges, p. 419. 
recusar a lei de conservação de energia por completo, nem de postular que as coisas acontecem por puro capricho, mas delimitar o seu domínio: ela é, como todas as leis da física, um resumo de observações feitas a partir de fenômenos físicos. Para Bergson, a realidade progride por criação e não por conservação. Assim, pode haver mais no efeito do que na causa - há algo nele que o faz solidário dela e é por isso que pode ser tomado como efeito ${ }^{92}$. A realidade é representada como um todo perfeitamente coerente e sistemático porque sustentado por uma armadura lógica que é a própria verdade, havendo, portanto, adequação entre o que deve ser conhecido e as condições de conhecimento. Ciência e metafísica comungam, nessa perspectiva, da mesma realidade e do mesmo método que permite conhecê-la. Se a ciência passou, sobretudo após as transformações da física moderna, a se pautar cada vez mais pela matemática ou pelo raciocínio lógico, isto se fez porque tal é a forma que melhor responde à realidade e mais satisfaz o nosso entendimento, o que não significa que o mesmo deva ser feito na ou pela metafísica. O que convém ressaltar é que a aceitação, consciente ou inconsciente, de uma unidade de saber entre ciência e metafísica, posta desde os gregos, origina e alimenta uma circularidade entre ambos: a ciência postula uma lei (conservação de energia, por exemplo) cujo fundamento é uma tese metafísica (imutabilidade de Deus), e a metafísica postula um fundamento que nada mais é do que a afirmação dogmática, no entender de Bergson, daquilo que a própria inteligência, órgão da ciência, pusera como ponto de partida: a unificação e subsunção de todas as coisas a um princípio único. Por isso, a exigência bergsoniana de distinção metódica entre ambas. O outro lado da crítica bergsoniana da unidade do método, que não podemos obviamente deixar de mencionar, visa à concepção kantiana, que confere apenas ao conhecimento científico o estatuto de teoria ${ }^{93}$. Feita a distinção metódica e separados os domínios do conhecimento, a Crítica é ultrapassada em direção a uma nova metafísica, como teremos oportunidade de ver.

91 Sabemos que, para Bergson, não há diferença de natureza entre o cérebro e a medula.

92 "Ela exprime o que se passa em um domínio em que ninguém nunca sustentou que havia capricho, escolha ou liberdade. Trata-se precisamente de saber se ela se verifica ainda no caso em que a consciência (a qual, após tudo, é uma faculdade de observação e que experimenta à sua maneira) se sente em presença de uma atividade livre [...]. Aliás, é bem possível que, se a vontade é capaz de criar energia, a quantidade de energia criada seja muito fraca para afetar sensivelmente nossos instrumentos de medida: o efeito poderá, no entanto, ser enorme, como o da faísca que faz explodir a pólvora” (E.S., p. 35).

93 A esse respeito, conferir ainda o livro do professor Franklin Leopoldo e Silva, no qual lemos que: "Visando estas concepções, Bergson propõe-se criticar na verdade a unidade do método que é correlata da unidade do saber. Da mesma forma que para os clássicos existe um único método modelado sobre um único paradigma (a matemática), para Kant a exclusão da metafísica do campo teórico é decorrente da delimitação do alcance do método transcendental. [...] o pressuposto é que um único método é possível, já que não pode haver dois tipos diversos de conhecimento objetivo, o que equivaleria à presença de duas verdades no conhecimento. A separação bergsoniana dos domínios de conhecimento com igual direito à certeza rompe, pois, com o paradigma clássico e com o idealismo crítico, na medida em que este restringe o alcance do paradigma em vez de substitui-lo, através da delimitação do campo teórico” (Cf. Bergson: intuição e discurso filosófico, p. 32). 
Ao realizar a crítica genética da inteligência, Bergson mostra, como apontamos anteriormente, que todas as suas operações tendem à geometria, "como ao termo em que encontram seu melhor acabamento", porque a geometria lhes é necessariamente anterior - imanente à nossa representação do espaço -, e porque ela "é a grande mola de nossa inteligência e que a faz funcionar” (E.C., p. 212). Ao analisar tais operações, Bergson as reduz a um mesmo nível, demonstrando como todas são, na verdade, redutoras. Isto pode ser visto, por exemplo, na análise da dedução e da indução, feita no terceiro capítulo d' A Evolução, em que ambas são identificadas ao final do percurso, porque conduzem, de um e de outro modo, à geometria como horizonte ou limite de suas operações:

Nossas induções são certas, aos nossos olhos, na exata medida em que fazemos diluir as diferenças qualitativas na homogeneidade do espaço que as subtende, de sorte que a geometria é o limite ideal de nossas induções tanto quanto de nossas deduções. O movimento, ao termo do qual está a espacialidade, deposita, ao longo de seu trajeto, tanto a faculdade de induzir como a de deduzir, a intelectualidade inteira (E.C., p. 217).

Ambas são operações intelectuais regradas pela matéria ou pelo espaço que a subtende. Isto significa que, para Bergson, a dedução, por exemplo, não pode ser definida como uma operação do espírito que se realizaria apenas por sua própria força, e sim que se trata de uma operação ligada à exterioridade, assim como a indução. As certezas advindas do raciocínio feito a partir de puras determinações espaciais são estendidas à totalidade da realidade, como afirmamos. E novamente aqui o que importa ressaltar é que se trata de um procedimento permeado de imaginação, pois a transposição das determinações espaciais para todos os domínios ocorre com o seu intermédio ${ }^{94}$. Mas, a "imaginação só procede assim porque ela fecha os olhos a dois pontos essenciais” (E.C., p. 216), a saber: ao tempo, que não conta no mundo do físico e do geômetra, e às qualidades, consideradas como passíveis de serem sobrepostas umas às outras, como as grandezas o são. Estando sempre relacionada à materialidade e à espacialidade, o que se evidencia na inteligência não é só uma força operante, mas também, digamos, uma força imaginante. A intelectualidade em seu

94 “Ora, se minha certeza é perfeita no caso em que raciocino sobre puras determinações espaciais, não devo supor que, nos outros casos, ela o será ainda mais quanto mais se aproximar desse caso limite? E ainda, não seria o caso limite que transparecia através de todos os outros e que os coloria, segundo sua maior ou menor transparência, de uma nunça mais ou menos pronunciada de necessidade geométrica? De fato, quando digo que minha água, colocada sobre meu fogareiro, vai ferver hoje como o fazia ontem, e que isto é de uma absoluta necessidade, sinto confusamente que minha imaginação transporta o fogareiro de hoje sobre o de ontem, a panela sobre a panela, a água sobre a água, a duração que se escoa sobre a duração que se escoa, e que o resto parece, desde então, ter também de coincidir, pela mesma razão que faz com que os terceiros lados de dois triângulos sobrepostos coincidam se os dois primeiros já 
todo opera pela dissolução do heterogêneo (tempo e qualidades) na homogeneidade do espaço. Nas suas operações, trata-se de reduzir as novidades a elementos idênticos antecedentes. "Deduzir e induzir é sempre reduzir, ou seja, quantificar e identificar, enquanto produzir é qualificar e diversificar" 95 .

Ao final da análise da inteligência, no terceiro capítulo d'A Evolução, Bergson resume os seus atos, ou o que ela diz, a saber: que "a causa determina o seu efeito", que "o mesmo condiciona o mesmo", que "tudo se repete" e, finalmente, que "tudo está dado", o que significa feito, pronto, acabado, posto por toda eternidade. Desse modo, para as doutrinas filosóficas que dela partem e nela findam, haveria, como consideramos, um sistema da verdade preexistente ao nosso conhecimento e que encerraria arquitetonicamente a realidade. Tal sistema se caracterizaria pela unicidade, eternidade e imutabilidade. É contra essas doutrinas que Bergson se volta na aspiração da reinstauração metafísica, ou melhor, contra o consenso, comum à maioria dos filósofos, de afirmar a unidade da natureza e representá-la sob forma abstrata e geométrica (E.C., p. 191). A afirmação da dualidade entre vida e matéria é a arma bergsoniana contra tal sistematização. A assunção de duas ordens inversas uma à outra - ordem vital e ordem geométrica - interdita por si que "possamos imaginar graus intermediários” entre os dois domínios (E.C., p. 237). Assim, diferentemente dos sistemas que postulam um princípio eterno e imóvel, do qual os seres temporais seriam degradações, não há hierarquia entre as dimensões do mundo bergsoniano, uma vez que ambas são dimensões do absoluto $^{96}$. E mais: separados os domínios, finda-se a circularidade entre ciência e metafísica, findando-se também a sustentação e a alimentação ilusória entre ambas, visto que, nas palavras do professor Bento Prado Júnior: “as ilusões que velam ou obscurecem a experiência do Ser abrigam e fundamentam as ilusões que deformam a dinâmica do conhecer"97, e o conhecer (pela inteligência), como vimos, também é projetado para a dimensão do ser - na busca da unidade. Tanto a ilusão de uma única ordem no mundo quanto a de que o imóvel é anterior ao móvel repousam, no fundo, no esquema da passagem do Nada ao Ser, e isto pode ser visto também pelo exame da ilusão da passagem do possível à realidade, essencial na sustentação da unidade substancial no sistema espinosano, tal como Bergson o vê. Voltemos, então, à critica da idéia do Nada, cujo propósito é o desmascaramento da ontologia consagrada à repetição de modo a desvendar os fundamentos da

coincidirem entre si” (E.C., p. 216).

95 Canguilhem, G., op. cit., p. 152-3.

96 O conhecimento das partes (instantes, paradas) é legítimo enquanto tal, isto é, enquanto conhecimento parcial: conhecimento que capta uma dimensão do real - o conhecimento científico descobre um modo do Ser (alcança uma das metades do Absoluto) e, se não recobre o todo, isto não o faz menos verdadeiro e completo, ao contrário.

97 Bento Prado Júnior, op. cit. p. 40. 
duração e de uma ontologia que, a ela dedicada, só pode se definir pela presença e pela diferença, porque a duração é a criação contínua de imprevisível novidade ${ }^{98}$.

\section{A necessidade lógica do pensamento matemático e a substância espinosista}

Refutada a anterioridade do Nada e a sua equiparação à afirmação ${ }^{99}$ - ele não precede o Ser, ao contrário, e nem possui a sua abrangência -, resta saber o que está por trás da obstinação que persegue a filosofia, em suas diferentes manifestações, de colocar a afirmação e a negação sobre uma mesma linha, dotando-as da mesma objetividade e dissimulando o caráter subjetivo da negação, ou sua dependência em relação ao espírito humano e à vida social. Segundo Bergson, “a razão disto está, sem dúvida, em que negação e afirmação se exprimem, uma e outra, por proposições, e em que toda proposição, sendo formada por palavras que simbolizam conceitos, é coisa relativa à vida social e à inteligência humana” (E.C., p. 291). Há que se levar em conta, como dissemos, o tipo de experiência a que ambas se referem. Um juízo afirmativo traduz uma experiência vivida, um conhecimento direto que pode se dar, por exemplo, a partir de sensações táteis ou visuais, que estariam na base da representação. Ele manifesta algo que precede o próprio discurso, enquanto a negação não se refere diretamente a um objeto, constatando uma substituição na qual o que se leva em conta é apenas o substituído e não o substituinte - eis o seu caráter subjetivo. O substituído é o que se mantém apenas no espírito de quem nega e não corresponde à realidade. Então, para falar dele, nas palavras de Bergson, "é preciso virar as costas para a realidade, que corre do passado para o presente” (E.C., p. 293). É preciso manter um apego ao passado. Em contraposição, e

Em resumo, para um espírito que seguisse pura e simplesmente o fio da experiência não haveria vazio nem nada, mesmo relativo ou parcial, não haveria negação possível. Um semelhante espírito veria fatos sucederem a fatos, estados a estados, coisas a coisas. O que ele notaria a todo momento

\footnotetext{
98 No livro do professor Bento Prado Júnior, lemos a esse respeito que: “À Ausência, que é a miragem instaurada pela práxis e que institui a Ontologia da Repetição, é possível opor o campo luminoso da Presença, como condição de possibilidade de uma descrição da história do real enquanto contínua criação de novidade, enquanto ponto de confluência entre liberdade e inteligibilidade: isto é, duração” (op. cit., p. 41). Sobre a filosofia bergsoniana como filosofia da diferença, conferir, também, o Bergsonismo, de Gilles Deleuze.

99A negação não pode, como vimos, aspirar à mesma condição da afirmação, uma vez que ela não determina nada “é apenas a metade de um ato intelectual, do qual a outra metade permanece indeterminada” -, indicando apenas a necessidade de se substituir um julgamento afirmativo por outro, cujo conteúdo não é especificado. Isto significa que não se pode tratá-las como simétricas, ou melhor, "é, portanto, em vão que se atribuiria à negação o poder de criar idéias sui generis, simétricas às que a afirmação cria e dirigidas em sentido contrário. Nenhuma idéia sairá dela, pois não tem outro conteúdo que o julgamento afirmativo que ela julga” (E.C., p. 289).
} 
são coisas que existem, estados que aparecem, fatos que se produzem. Ele viveria no atual e, se fosse capaz de julgar, só afirmaria a existência do presente (E.C., p. 293-4).

Ele viveria no presente e na plenitude da presença, não no passado e no desamparo da ausência. Mas, tal espírito não poderia ser confundido com a inteligência e estaria livre dos dualismos e equívocos inscritos na própria estrutura da linguagem. A experiência imediata, anterior à tradução em palavras, é algo que a linguagem acaba por ocultar, pois, para Bergson, a linguagem se inscreve no descontínuo. Assim, afirmação e negação aparecem como simétricos devido à própria estrutura da linguagem. Ela é importante porque seus símbolos condensam a diversidade, permitindo que o real seja apreendido de acordo com a identidade de reações que provoca - a palavra obscurece a pluralidade dos seus significados de modo que a multiplicidade a que ela originalmente se referia passa a ser remetida à unidade do termo, deixando de existir a diferença entre essa unidade e a pluralidade a que ela se refere ${ }^{100}$. Como exposto no Ensaio, “a consciência atormentada por um insaciável desejo de distinguir, substitui o símbolo à realidade, ou só percebe a realidade através do símbolo” (E., p. 104). A essência da inteligência está em operar essa distinção por meio de descontinuidades e paradas, sem aderência ao movimento ou ao próprio "fio da experiência”. Desse modo, a razão da permanência do Nada está inscrita na própria inteligência. A função da inteligência é a de presidir a ações e toda ação humana tem seu ponto de partida em uma insatisfação e, por isso mesmo, em um certo sentimento de ausência. Esta se refere a uma utilidade, mais ainda do que a uma coisa, uma vez que é a utilidade que o trabalho humano visa. E a linguagem também se inscreve nesse caráter instrumental e utilitário, bem como o reproduz, fazendo apelo à ação imediata ou assinalando coisas ou propriedades com vistas à ação iminente (prescrevendo ou descrevendo). Isto significa que

\begin{abstract}
Nossa vida se passa assim a preencher vazios que nossa inteligência concebe sob a influência extra-intelectual do desejo e da falta, sob a pressão das necessidades vitais: e, se se entende por vazio uma ausência de utilidade e não de coisas, podemos dizer, nesse sentido inteiramente relativo, que vamos constantemente do vazio ao pleno. Tal é a direção na qual caminha a nossa ação (E.C., p. 297).
\end{abstract}

Especulando sobre as coisas, a inteligência fará o mesmo, implantando em nós a idéia de que a realidade preenche um vazio e que o Nada preexiste a todas as coisas, de direito ou de fato. A

100 A esse respeito, conferir o livro do professor Franklin Leopoldo e Silva, Bergson: intuição e discurso filosófico, ao qual devemos parte das idéias que apresentamos aqui no que diz respeito sobretudo à linguagem. O texto 
análise bergsoniana busca dissipar tal ilusão fundamental, evidenciando que a idéia de Nada é uma idéia que se destrói a si mesma ou se reduz a uma simples palavra. O objetivo dessa análise é justamente buscar a "mola secreta” que estaria por trás de toda especulação filosófica, seu conteúdo latente e inconsciente, cuja raiz se encontra no universo imaginário do homo faber. Antes de qualquer coisa, somos homens de ação e agimos sob a pressão das necessidades vitais. Nossa inteligência comanda nossas ações sob a influência extra-intelectual do desejo e da falta, como vimos. Uma inteligência que seguisse o “fio da experiência” não conheceria as coisas “por fora”, externamente, não sonharia com o ausente, nem viveria a experiência da falta. Vivê-la é essencial à inteligência, assim como antepor um Nada originário ao Ser, quando se trata de especulação filosófica. Para Bergson, cabe superar toda oposição estéril entre conceitos ou palavras, a qual não tem qualquer respaldo na realidade. Se a inteligência não pode se furtar à sua vocação prática, não é a ela que cabe a especulação filosófica. Suprimido o interesse ou a afecção, próprios à inteligência, o que permanece é “a realidade que flui, e o conhecimento indefinidamente renovado que ela imprime em nós de seu estado presente” (E.C., p. 294). Um espírito que segue o "fio da experiência” procede intuitivamente, apreende o Ser "por dentro", pela interioridade, o que só pode acontecer a uma consciência que, para além de ser consciência de algo, é consciência de si mesma. Trata-se, pois, para Bergson, de fazer uma espécie de cura do espírito, o que não significa mudar a essência da inteligência ou transformá-la em intuição, por meio de um aperfeiçoamento, já que ambas são naturalmente distintas. A cura seria, digamos, a compreensão de seus limites e a delimitação de seu alcance - não forçá-la fora de seu domínio -, seria o seu uso adequado. Seria também uma inversão de sentido em relação ao seu modo de operar habitualmente ${ }^{101}$. Logo no início da análise da idéia do nada, Bergson adverte, em uma nota de rodapé, que tal texto já aparecera antes, sob a forma de artigo, na Revue philosophique, de novembro de 1906. A diferença entre os dois textos é mínima. Há, contudo, no final do artigo, uma parte pequena, que não consta do livro, mas interessante para pensarmos a cura:

Um vez a ilusão dissipada, os problemas que surgem em torno dela se esvanecem. A criança cujo sonho conduz à lua se vê suspensa tão alto sobre a terra, tão rodeada de vazio, que é tomada de vertigem e acaba

correspondente a esta nota se encontra na primeira parte do livro, p. 88.

101 “Como erradicar uma inclinação tão profunda? Como levar o espírito humano a inverter o sentido de sua operação habitual, como levá-lo a partir da mudança e do movimento, considerados como a própria realidade, e a não ver mais nas paradas ou nos estados senão instantâneos que são tomados de algo movente? Será preciso mostrar-lhe que, embora a marcha habitual do pensamento seja praticamente útil, cômoda para a conversação, a cooperação, a ação, ela conduz a problemas filosóficos que são e que permanecerão insolúveis, por terem sido postos às avessas” (P.M., p. 78). 
por se sentir cair: algumas noções de cosmografia, ou mesmo uma simples reflexão sobre a natureza do alto e do baixo, a convenceria de que sua vertigem é ilegítima e dela a curaria, se podemos nos exprimir assim, por razão demonstrativa. Casos de vertigem ilegítima se apresentam também em filosofia, e pode ser útil assinalá-las, mesmo que seja apenas para afastar dificuldades ilusórias e causas artificiais de problema, antes de olhar de frente os verdadeiros problemas ${ }^{102}$.

Dissolvidos os falsos problemas nos quais a filosofia sempre se enredou - antinomias vertiginosas -, todos eles convergindo para o princípio da prioridade do nada (a mais primitiva das ilusões), que atravessa a história da filosofia, uma nova metafísica pode surgir. A crítica da idéia do nada liberta a filosofia dessa vertigem ilegítima, curando-a: o Ser não terá de vencer o Nada para se colocar a si mesmo. Mais ainda: “essa longa análise era necessária para mostrar que uma realidade que se basta a si mesma não é necessariamente uma realidade alheia à duração” (E.C., p. 298). O desprezo pelo temporal sempre fora, ao longo de toda história da filosofia, consequência do princípio da prioridade do Nada, pois

Se passamos (consciente ou inconscientemente) pela idéia do nada, para chegar à do Ser, o Ser ao qual se chega é uma essência lógica ou matemática, portanto intemporal. Desde então, uma concepção estática do real se impõe: tudo parece dado de uma só vez na eternidade. Mas, é preciso se habituar a pensar o Ser diretamente, sem fazer um desvio, sem se dirigir, primeiramente, ao fantasma de nada que se interpõe entre ele e nós. É preciso procurar, aqui, ver para ver, e não mais ver para agir. Então, o Absoluto se revela muito perto de nós e, em certa medida, em nós. Ele é de essência psicológica, e não matemática ou lógica. Ele vive conosco. Como nós, mas, por certos lados, infinitamente mais concentrado e mais contraído sobre si mesmo, ele dura (E.C., 298).

A filosofia tradicional é caracterizada pelo desprezo em relação ao devir - não é suficientemente forte para vencer o Nada, sendo por ele constantemente reabsorvido - e pelo privilégio da eternidade em contraposição à temporalidade, o que significa uma desvalorização do que se dá na experiência - o ser verdadeiro deve ter uma existência lógica. Para Bergson, a metafísica tradicional teria desprezado o que se passa na experiência, porque sempre privilegiara a eternidade e a autoprodutividade que podem ser encontradas somente no nível dos seres matemáticos ou das proposições lógicas, uma vez que estes não se colcoam sob quaisquer determinações temporais. De diferentes modos, antigos e modernos fizeram o mesmo, sendo apenas 
uma diferença de grau aquilo que os separa ${ }^{103}$. Ainda que os gregos submetessem as leis aos gêneros, enquanto os modernos fizeram o inverso, nos dois casos, o mesmo fundo se mantivera: a identificação da realidade com o que não é temporal, e a consideração de que a experiência ou o que se dá sob a égide do tempo é sombra ou ilusão. A diferença de grau entre ambos indica que houve um aprimoramento dessa tendência de modo que, com os modernos, ela teria chegado ao seu ápice: a metafísica, que sempre procurara estabelecer-se segundo os cânones da necessidade matemática, postulará a mathesis universalis ${ }^{104}$ e, no espinosismo, serão indissociáveis o método geométrico e o conteúdo da metafísica. Para apresentarmos a maneira como Bergson compreende a necessidade lógica da filosofia espinosista, voltar-nos-emos aqui a um curso sobre a história da filosofia moderna e contemporânea em que algumas aulas são dedicadas à exposição do pensamento de Espinosa. Num primeiro momento, Bergson demonstra porque o espinosismo é o acabamento da filosofia de Descartes, a versão mais aprimorada de uma de suas tendências, e, num segundo, pelo estudo da Ética, ele aborda a substância espinosista - explicando o paralelismo como seu efeito ou desdobramento -, bem como revela o principal problema a que esse sistema leva: a rejeição da liberdade, incompatível com a arquitetônica matemática.

As lições sobre a história da filosofia moderna e contemporânea foram ministradas no Liceu Henri-IV, no ano letivo de 1893-1894, ou seja, pouco antes da publicação de Matéria e memória. A parte consagrada ao filósofo holandês se inicia com as “dificuldades metafísicas consideráveis” às quais a filosofia cartesiana leva, “mesmo colocando a moral em segundo plano” (Cours III, p. 87). A primeira diz respeito à prova ontológica da existência de Deus, pois Descartes passaria da possibilidade da existência de Deus à sua realidade, sem justificar de modo suficiente a passagem, visto que ele não teria identificado abertamente o real com o possível. A segunda se refere à união da alma com o corpo, a qual ele constataria após ter distinguido profundamente a extensão e o pensamento, sendo incapaz de indicar como cada uma dessas substâncias age sobre a outra. A

L'Evolution créatrice, edição crítica, p. 505.

103 A ciência moderna, versando sobre grandezas, distingue-se da dos antigos porque trabalha apenas em vista de medir e, para realizar a medição de forma exata, os modernos vão buscar leis que vinculam variáveis, enquanto os antigos buscavam gêneros. A diferença entre ambas, contudo, é somente de grau, e não de natureza, para Bergson, e a nova física servirá ainda de modelo para a unificação da representação da realidade. Sobre o quadro da unidade do saber a partir do pressuposto da unidade do ser, lemos em Bergson: intuição e discurso filosófico que: "É principalmente esta unidade que a metafísica se encarrega de fundar e explicitar; portanto, a metafísica não se constituiu como conhecimento de outro tipo que ofereceria a alternativa à abordagem discursiva do real. Assim a metafísica se deu por tarefa prosseguir o conhecimento científico, prolongá-lo e fundamentá-lo a fim de, dirigindo a constituição de seu próprio saber na mesma direção do saber científico, testemunhar a unidade do saber” (Cf. Bergson: intuição e discurso filosófico, p. 150).

104 "O sonho de uma matemática universal é apenas uma sobrevivência do platonismo. A matemática universal é o que se torna o mundo das idéias quando se supõe que a Idéia consiste em uma relação ou em uma lei, e não mais em uma coisa” (P.M., p. 222). 
terceira estaria em ter atribuído a Deus uma liberdade de indiferença, e feito do mundo material um sistema de causas e efeitos submetidos às leis da mecânica, tornando obscura a questão da criação e da liberdade do homem, que deve ser conciliada com a ação contínua de Deus. "Essas três dificuldades graves, Espinosa as elucida por uma concepção nova, uma concepção original da relação entre o real e o possível, primeiramente, da relação da causa com o efeito, em segundo lugar, e da relação do infinito com o finito, em terceiro lugar” (Cours III, p. 87). Tal concepção nova e original é, antes de mais nada, matemática, e o espinosismo, segundo Bergson, é incompreensível para quem não o apreende de acordo com a verdadeira natureza das proposições matemáticas e com a matemática cartesiana, mais particularmente. Para compreendê-lo, “algumas considerações preliminares são indispensáveis”. Primeiro, é preciso levar em conta que a realidade dos seres matemáticos não se separa de sua possibilidade, ou seja, apenas por serem possíveis, os seres matemáticos existem, e os objetos (linha, circunferência, elipse) que os matemáticos estudam são verdadeiros seres para eles. Donde se segue que "o ato pelo qual se estabelece a possibilidade de uma essência matemática é, portanto, o mesmo pelo qual se constata sua existência e, ainda, a sua eternidade” (Cours III, p. 88). Em segundo lugar, não podemos ignorar que, ao ser enunciada a definição de uma figura geométrica, pode-se tirar um número indefinido de teoremas que exprimem todas as propriedades dessa figura. Todos os teoremas existem na definição e exprimem, portanto, a infinita multiplicidade da qual a unidade é repleta. A definição cria os teoremas porque eles resultam necessariamente dessa definição pelo simples fato de ter sido posta. Os teoremas são, portanto, “eternos como essa definição, são coeternos, como diria Espinosa”. Em terceiro lugar, devemos considerar que um objeto matemático é suscetível de se exprimir de diferentes modos e que cada expressão o contém inteiramente. Um círculo, por exemplo, pode se expressar geométrica ou algebricamente, por uma equação do segundo grau. Ele pode até se expressar de outras maneiras, mas nós só conhecemos duas. Unicamente pelo fato de ser possível, todas as suas expressões, conhecidas ou não, existem ou são igualmente postas. Se se entende a existência no sentido matemático, não há diferença entre possibilidade e realidade, e a relação de causa e efeito é uma relação necessária de princípio a conseqüência, porque pode ser reduzida a uma relação de identidade - nada há no efeito que não se encontre na causa ou, uma vez posta a definição, todos os teoremas dela saem porque nela existem. Isto implica o cerne da crítica bergsoniana, qual seja, a redução de todas as coisas a um princípio único, do qual elas “saem” porque nele existem, o Todo ou substância, a unidade à qual a multiplicidade equivale. É este princípio que dá a razão do paralelismo, como mostramos no primeiro capítulo, transformando-o numa doutrina propriamente dita. Para Bergson, ele é apenas uma repetição do modo de sistematização grego. Repetição, 
contudo, diferenciada pela consistência matemática na qual ela se acosta. Esta, a consistência matemática do espinosismo, fará do sistema algo tão difícil de ser combatido que todo pensamento que não rompa com a ossatura do mesmo, com os procedimentos da inteligência, se inclinará em sua direção. Não é estranho que Bergson inicie o capítulo IV de A Evolução criadora, que também trata do "devir real”, pela crítica da existência tomada no sentido matemático ou da identificação da realidade das coisas com a sua possibilidade, o que significa negar a existência enquanto duração e criação. A crítica é também contra a eternidade e a equivalência entre unidade e multiplicidade, sem que tenha que optar por uma ou outra, ou seja, sem recair nas dicotomias cuja solução se inclina na direção do espinosismo porque, além de ser a direção da metafísica natural à nossa inteligência, da qual os gregos foram “vítimas”, é o seu ápice de rigor e refinamento.

Ao fazer um "resumo da Ética", nas lições sobre a história da filosofia moderna e contemporânea, Bergson inicia pela definição de Substância: “o que existe em si e é concebido por si” ${ }^{105}$; concluiremos, assim, que há uma Substância, que ela existe, se dermos à palavra existência seu sentido matemático, pois este “é o postulado oculto de todo o espinosismo” (Cours III, p. 89). Essa Substância é una e infinita e ela é Deus, o qual possui uma infinidade de atributos, que exprimem a sua essência, e dos quais só conhecemos dois, o pensamento e a extensão (Natura naturante). Cada atributo, por sua vez, manifesta-se por uma infinidade de modos (Natura naturada). Em outros termos, o mesmo ser pode ser visto em sua unidade e infinidade ou em sua multiplicidade e indefinidade, pois ele não é causa exterior do mundo, mas causa imanente. Desse modo, “o mundo é coeterno a Deus e há, entre as coisas criadas e o criador, a mesma relação que há entre os teoremas que saem de uma definição e a própria definição” (Cours III, 90). As considerações preliminares, supramencionadas, são mesmo necessárias para entender a Ética do ponto de vista bergsoniano, pois toda a compreensão se faz a partir do “postulado matemático oculto”. Assim, a existência da substância deve ser vista como uma existência matemática que, ao ser postulada, faz com que todas as coisas dela saiam de modo necessário e eterno. Os atributos expressam a sua essência e essa expressão também deve ser tomada em seu sentido matemático. O exemplo que Bergson fornece para a expressão em sentido matemático dos atributos da substância é também um exemplo usado muitas vezes pelo próprio Espinosa para demonstrar ou esclarecer suas idéias: trata-se do círculo. O que permite o exemplo do círculo é a invenção da geometria analítica por Descartes ${ }^{106}$. Lemos que o

\footnotetext{
105 Trata-se da terceira definição da Parte I da Ética, a saber: "Por substância entendo isso que é em si e é concebido por si, isto é, isso cujo conceito não carece do conceito de outra coisa a partir do qual deva ser formado” (Tradução do Grupo de Estudos Espinosanos da Universidade de São Paulo, doravante GEE, p. 1).

${ }^{106} \mathrm{O}$ curso sobre as teorias da memória mostra que essa invenção chocou muito os contemporâneos de Descartes e foi uma das mais belas descobertas que já se fez, ainda que a idéia existisse antes do próprio Descartes, mas foi ele quem a
} 
...círculo se exprime por si mesmo por uma figura geométrica, por uma equação analítica e, talvez, por muitas outras maneiras, e ele está inteiramente em cada uma de suas expressões, assim como a essência infinita da Substância divina se exprime em Pensamento, em Extensão, e em uma infinidade de outros atributos que não podemos conhecer porque somos apenas modos do Pensamento e da Extensão. Deus está, portanto, inteiramente em cada um de seus atributos. (Cours III, p. 90)

Ora, o círculo já fora, antes de Bergson, usado para caracterizar o sistema espinosano como um saber fechado, atemporal e eterno em sua necessidade ${ }^{107}$. Entendendo a expressão dos atributos da substância como uma expressão matemática, Bergson encerrará o sistema espinosista na imobilidade (determinação e previsibilidade), o que significa ausência de criação e de livre escolha. Para ele, a Substância se exprime em atributos infinitos que se exprimem em modos, e "toda expressão é matemática”. A consequência a que somos levados, no que diz respeito à relação entre corpo e alma, é o paralelismo, como tivemos a oportunidade de mencionar no primeiro capítulo, pois, para que haja relação entre esses modos de atributos diferentes, que não se comunicam, uma vez que não há influência de corpos sobre idéias e de idéias sobre corpos, é preciso tomar a série dos modos da Extensão e a série dos modos do Pensamento como duas séries paralelas. "Como o diz fortemente Espinosa, 'ordo et connexio idearum idem est atque ordo et connexio rerum'”,108 (Cours III, p. 93). Para refletir sobre a relação entre a alma e o corpo, Bergson toma o exemplo do círculo se exprimindo por uma definição geométrica, que pode ser desenvolvida em teoremas "chamados A1, A2, A3, A4”, e por uma equação que pode ser desenvolvida em equações “chamadas a1, a2, a3, a4”. Cada termo, representado de maneira algébrica, corresponderá a um termo representado de maneira geométrica, sem que haja influência de um sobre o outro, porque "nem uma equação saberia influenciar uma figura, nem uma figura, uma equação, porque a forma e a quantidade são atributos diferentes, em sentido espinosista da palavra” (Cours III, p. 94). Dessa maneira, Bergson ilustra a correspondência entre os modos da extensão e os modos do pensamento - o que seria uma originalidade da doutrina espinosista -, sem interferência de um sobre o outro (interdição metafísica), ou "a maneira como todo corpo tem sua idéia e toda idéia tem seu estado do corpo". Estando os modos da extensão submetidos a um mecanismo inflexível, e correspondendo integralmente aos modos do pensamento, estes serão também encadeados de maneira rigorosamente

erigiu em método geral.

107 A esse respeito, conferir o artigo de Mariana de Gainza, "O tempo das partes. Temporalidade e perspectiva em Espinosa”. In Cadernos Espinosanos XXI. Ela refuta a leitura que Hegel faz do infinito atual espinosano.

${ }^{108}$ Proposição 7 da Parte II da Etica: “A ordem e conexão das idéias é a mesma que a ordem e conexão das coisas” 
necessária. A conclusão imediata é que: “Tudo o que é, existe necessariamente” (Cours III, p. 91). Mas, para Bergson, a liberdade é um aspecto da doutrina espinosista que deve ser explicado. Se ela não pode ser livre arbítrio ou livre escolha, o que seria insensato no sistema, é definida como o estado de um ser que não sofre constrangimento exterior, desenvolvendo-se em virtude de uma necessidade interior à sua natureza. “A liberdade espinosista é, portanto, o que chamamos a necessidade interna. Se desenvolver necessariamente, mas conformemente à sua própria essência, eis a verdadeira liberdade de acordo com Espinosa” (Cours III, p. 92). Ora, tal definição da liberdade não é em si problemática. Para Bergson, a liberdade necessária espinosista, no que tange à substância (Deus), é algo que adviria a uma definição matemática, caso ela tomasse consciência de si e de seu desenvolvimento em teoremas, sendo "livre no sentido em que o teorema é apenas a expressão de sua natureza e não depende de nenhuma outra causa”. Ou seja, o problema está na contradição entre a liberdade e a necessidade matemática, cuja consequência é, com a afirmação matemática do sistema, a negação da liberdade de fato (ainda que ela seja afirmada de direito). Como “sua filosofia não é apenas um tratado de metafísica”, mas também uma “doutrina moral”, ela deverá abordar a liberdade humana. Ainda neste caso, todo livre arbítrio é ilusão ou quimera e a liberdade significa que "tudo o que fazemos segue necessariamente do que nós somos, e todo conselho é inútil, assim como todo arrependimento quanto ao que poderíamos ter feito é pueril” (Cours III, p. 95). Definição que também não é problemática, mas que, inserida no conjunto do sistema, padecerá as suas restrições.

Metafísica e moral são, ao final, reconduzidas à geometria. E, se “o papel do moralista é o de definir o bem e o mal”, e determinar “em quais condições se produz a escravidão, ou a submissão de uma alma às paixões”, ele "não reforma mais a humanidade, tratando do bem e do mal, do que o geômetra modificaria a posição de um corpo determinando as condições de seu equilíbrio” (Cours III, p. 95). Trata-se de uma moral que afirma dois estados da alma (escrava ou livre), o que significa escapar à paixão ou passar da idéia inadequada à adequada, quando, então, ela "pensa, não sob forma finita, mas sob forma de eternidade, sub specie aeterni” (Cours III, p. 96). Para Bergson, Espinosa, “moralista”, considera o bem e o mal como o que aumenta ou diminui a nossa força, ou o nosso ser, de modo que só existimos plenamente quando nos colocamos pelo pensamento em Deus, dando-nos conta da universal necessidade. A liberdade consiste, "para o homem, na consciência que ele toma de suas relações com Deus, isto é, na necessidade à qual ele obedece” (Cours III, p. 96; grifo nosso), o que significa também a beatitude ou a nossa eternidade, pois "pensando as coisas sob

(Tradução do GEE). 
a forma da eternidade, nós coincidimos, por assim dizer, com o eterno”. A liberdade é uma obediência à necessidade e uma coincidência com a eternidade. O problema é que necessidade e eternidade aqui foram entendidas sem qualquer referência a uma experiência vivida efetivamente. Neste caso, paixões e ações são tratadas, por Bergson, como existências matemáticas.

Na explicação bergsoniana, a intuição ou conhecimento adequado, do terceiro gênero, significa se colocar pelo pensamento no Princípio, ou na "relação da coisa finita com esse Princípio infinito do qual ela emana, e, por conseguinte, com a infinidade de coisas finitas que são o equivalente desse Princípio” (Cours III, p. 95; grifo nosso). Libertar-se seria uma espécie de retorno ao Princípio do qual todas as coisas emanam de um só golpe, eternamente ${ }^{109}$. O problema está no Princípio, causa de todas as coisas que dele "saem", porque nele existem, cujos efeitos nada contêm que já não se encontre na causa. Ou seja, a relação da causa com o efeito, como Bergson mostrou nas explicações preliminares, é, nesse caso, uma relação necessária de princípio a consequência, o que significa uma relação de identidade. Ser livre é obedecer a essa necessidade, identificar-se com a causa, não havendo espaço para a diferença e a criação de algo novo ${ }^{110}$. Para Bergson, não há nada mais contrário à liberdade do que a idéia do efeito como realização de uma causa, ou seja, como algo determinado e previsível (totalidade fechada). Contra ela, o filósofo afirma a realidade como processo indeterminado e imprevisível (totalidade aberta) ${ }^{111}$. Se a crítica à idéia de causalidade se estende à tradição filosófica, cremos que há algo particular na visão que Bergson lança à causalidade espinosista, pois ele a compreende como aquilo que é o núcleo desse sistema, pela concepção matemática que o sustenta. Quer se trate da causalidade da substância imanente, quer se trate da dos modos, a consequência (ação livre) é sempre realização da causa e nunca criação ou verdadeira produção de novidade.

Num curso sobre “As teorias da alma”, também ministrado no Lycée Henri-IV, em 1894, Bergson mostra que a concepção espinosista da causalidade seria algo como uma tendência

109 Pensamos assim que o conhecimento sub especie aeternitatis, ao qual Bergson se refere no curso, parece próximo, para ele, do êxtase plotiniano, da identificação da alma com Deus, visto que "ela e Deus são uma só e mesma coisa", sendo a beatitude, portanto, essa "verdadeira posse de Deus, a volta da alma a Deus, a absorção em Deus”. A necessidade do sistema impossibilita a eficácia da liberdade no sentido de uma livre escolha.

110 A seguir, discutiremos a crítica de Bergson à causalidade assim definida. Trata-se de um dos temas mais importantes do bergsonismo. A duração significa criação do que não era, de uma "radical novidade", não podendo se furtar à diferença.

111 Sobre a "filosofia da vida" de Bergson como afirmação da indeterminação e da imprevisibilidade, conferir o artigo de Franklin Leopoldo e Silva, "Ontologia e liberdade em A evolução criadora: A criação", no qual lemos ainda que: "enquanto a teoria tradicional considera que a indeterminação estaria sempre afetada pela aparência e pela provisoriedade, Bergson entende que o encadeamento determinado dos fenômenos é fruto de uma construção intelectual fundada no valor pragmático dessa aparência, espécie de ilusão necessária inerente ao pendor da inteligência. Nesse sentido, o determinismo é relativo, e a indeterminação nos aproximaria do absoluto" (em Henri Bergson: crítica do negativo e pensamento em duração, p. 29). 
irreversível da filosofia de Descartes. Se o paralelismo é uma solução para o problema moderno da relação da alma com o corpo, ele é uma tendência à qual a filosofia de Descartes se inclinava (como expusemos no primeiro capítulo), ou ainda, uma tendência que surge na modernidade, porque está ligada à idéia que ela faz da causalidade. A relação de causalidade é, antes de mais nada, uma relação de sucessão: de uma causa dada, segue um efeito. Mas, ela também pode ser pensada como uma relação de inclusão, o que leva à constatação de que um efeito só pode ser inteligível se estiver contido ou implicado na causa. Deste modo, a relação de causalidade só é inteligível entre termos do mesmo gênero. Toda relação entre termos de gêneros opostos envolveria um mistério a ser esclarecido. O mistério só aparece, segundo Bergson, aos que representam a ação, influência ou relação causal de modo exato, ou seja, com uma explicação geral que é fundamental para a filosofia moderna: a dedução. A relação ou a ação recíproca entre alma e corpo só serão inteligíveis se se puder deduzir algo que se passa em um pelo outro. Os filósofos antigos não se preocupavam em explicar a ação do corpo sobre a alma ou da alma sobre o corpo, limitando-se a constatá-la, não a punham como problema. Eles tinham, contudo, uma grande dificuldade em conceber uma alma individual, e a idéia de uma "alma do mundo”, o espírito, era comum aos filósofos da antiguidade. A filosofia moderna colocará a individualidade do nosso pensamento ou da nossa personalidade. “Tais são os pontos para os quais se voltará a atenção e a argumentação dos filósofos modernos, de Descartes aos nossos dias” (Cours III, p. 218). Para Descartes, a alma estará ligada a Deus, seu criador, cuja vontade lhe assegura a existência. Ela é uma criação do livre arbítrio de Deus. Mas, esse ato divino não pode ser arbitrário porque, se for, será ininteligível, pois não se pode pensar uma relação de causa e efeito puramente arbitrária. Se ele não é ininteligível (arbitrário), terá de ser necessário. "E, se ele é necessário, ou seja, se a existência da alma é posta apenas pelo fato de ser posta a existência de um Ser perfeito, então, nossa alma faz parte da substância de Deus, nossa alma é em Deus” (Cours III, p. 225). Consequência que será deduzida por Espinosa, mas à qual muitos “discípulos” de Descartes se inclinariam e da qual o próprio Descartes não se distanciaria, ao colocar a criação contínua e a vontade de Deus, da qual depende a existência de todas as coisas. Ela é uma consequência da concepção de relação causal, pois se considera que ela é tanto mais clara ou inteligível quanto mais for representada como uma relação matemática de princípio à consequência. Ou seja, ao se colocar uma causa, para saber como um efeito diferente pode sair dela, basta pensá-la como a relação que existe entre uma definição geométrica e suas consequências.

Assim, para Bergson, há três hipóteses possíveis no cartesianismo. A primeira leva à afirmação da existência do pensamento como algo que se basta a si mesmo, o que é impossível ou implica uma espécie de contradição. A segunda afirma que o pensamento é uma criação do livre 
arbítrio de Deus. Em Descartes, a primeira é substituída pela segunda, e “ele pára aqui”. Mas, a segunda "por um progresso contínuo vem se perder na terceira”, de acordo com a qual o pensamento existe apenas pelo fato de que Deus existe, é uma consequência necessária. Esse é o “progresso que assistimos de Descartes a Espinosa” (Cours III, p. 225). Quanto mais a relação causal for tomada como uma relação de princípio à consequência, mais ela tenderá ao espinosismo, que faz do pensamento e da extensão atributos que se correspondem paralelamente e que são efeitos de uma causa única, Deus. Para Bergson, toda a doutrina de Espinosa "se resume numa única fórmula”: “se Deus é a única causa, ele é a única substância, necessariamente” (Cours III, p. 233). Se ele causa todas as coisas, e causar é agir, a substância pode ser pensada como atividade, mas se trata de uma pura e absoluta atividade no sentido de que dela procedem, identificando-se, inteligibilidade e intemporalidade, realidade e idealidade - ato que é pensamento e produção de uma vez por todas, ou por toda a eternidade (“Tudo está dado”). Ora, nas últimas palavras sobre Espinosa no curso sobre “As teorias da alma”, lemos que as dificuldades erguidas pela introdução da necessidade sob sua forma mais rigorosa (a forma geométrica) têm como consequência, em suma, “o sacrifício, de um lado, da liberdade entendida no sentido da livre escolha e, de outro, da substancialidade, isto é, da existência real da alma individual” (Cours III, p. 236). Esse sistema é, pois, o simétrico oposto da filosofia da duração, e é ele, sobretudo, que Bergson tem como interlocutor na crítica da idéia do Nada, na qual está em jogo a redefinição da ontologia pela substituição do Ser da tradição (oposto simétrico do Nada) pela Vida entendida como “realidade movente e diferenciada, cujo fundamento é a temporalidade”112. Assim, lemos no início da crítica da idéia do nada, que:

Se me pergunto por que existem corpos ou espíritos em vez de nada, não encontro resposta. Mas que um princípio lógico $\mathrm{A}=\mathrm{A}$ tenha a virtude de criar-se a si mesmo, triunfando do nada na eternidade, isto me parece natural [...] Se o princípio de todas as coisas existe à maneira de um axioma lógico ou de uma definição matemática, as próprias coisas deverão sair desse princípio como as aplicações saem de um axioma ou as consequências de uma definição, e não haverá mais lugar, nem nas coisas nem no seu princípio, para a causalidade eficaz entendida no sentido de uma livre escolha. Tais são justamente as conclusões de uma doutrina como, por exemplo, a de Espinosa ou mesmo a de Leibniz, e tal foi a sua gênese (E.C., p. 300).

A crítica dirigida a Espinosa diverge da que Bergson direciona a Leibniz no sentido de que

112 Franklin Leopoldo e Silva, "Ontologia e liberdade em A evolução criadora: A criação” in Henri Bergson: crítica do negativo e pensamento em duração, p. 24. De acordo com esse texto, “A possibilidade de tomar contato com a Vida depende, pois, igualmente, de uma reforma do conhecimento e de uma redefinição da ontologia” (grifos nossos). 
não se trata de uma referência a possíveis como coisas ou acontecimentos preexistentes, nãocontraditórios com a sua realização concreta, mas a possíveis matemáticos que coexistem na substância única. No caso de Leibniz, há um princípio transcendente no qual os possíveis coexistem enquanto idéias e, neste sentido, consideramos que preexistem. No caso de Espinosa, trata-se de um princípio imanente cuja autoprodutividade não dá lugar à preexistência de idéias na mente daquele que as realiza conforme o critério do melhor. Assim, posta a imanência do princípio e sua lógica produtiva, Espinosa dá mais importância à extensão do que Leibniz, de modo que o paralelismo espinosista difere do leibniziano, porque, para aquele, Pensamento e Extensão estariam no mesmo nível e para este a extensão seria uma tradução do pensamento ${ }^{113}$. A consequência disto é que o mecanicismo universal - o mal maior deixado pela metafísica moderna, que o elevou a doutrina -, em Leibniz, seria um aspecto da realidade para nós, enquanto, em Espinosa, seria um aspecto da própria realidade (E.C., p. 350). De todo modo, trata-se, em ambos, de uma concepção construída em virtude de um princípio arraigado em nossa inteligência, segundo o qual toda verdade é eterna e a realidade é idêntica a ela. O que está no fundo dessa certeza é a ilusão do nada, cujo último avatar, como vimos, é o estatuto lógico do ser, o qual se aperfeiçoa no espinosismo. Neste, a articulação entre o método geométrico e o conteúdo da metafísica ocorre, nas palavras de Bento Prado Júnior,

à medida que a própria idéia do ens causa sui nasce de uma expansão ilimitada do pensamento de estilo geométrico. A necessidade lógica do pensamento matemático se desdobra e passa a projetar-se na necessidade do Ser absoluto, que se produz a si mesmo para além do tempo e sobre o fundo do $\mathrm{Nada}^{114}$

A duração e a experiência são, assim, não só desprezadas pela metafísica tradicional como eternamente banidas do domínio da filosofia, se esta não se confrontar efetivamente com o espinosismo.

113 “Para Leibniz, a extensão é ainda uma tradução, mas o pensamento é que é o original, e este poderia passar-se de tradução, a tradução sendo feita apenas por nós” (E.C., p. 350). A esse respeito, é interessante a análise de Gilles Deleuze, no livro Espinosa: uma filosofia da expressão, no qual é asseverado que o "paralelismo" cabe melhor a Espinosa, ainda que tenha sido afirmado apenas por Leibniz. Discutiremos esse tema polêmico no apêndice desta tese. 114 Bento Prado Júnior, op. cit., p. 47. Se tal leitura é ou não fiel à filosofia de Espinosa, isto não constitui o interesse do professor Bento Prado no livro citado. Ele expõe, nestas poucas palavras, e em alguns outros também breves momentos, a crítica de Bergson à filosofia de Espinosa, que teria levado ao extremo a capacidade lógica da inteligência. A problematização de tal leitura, que faremos no capítulo seguinte, não é uma refutação da exposição do professor - inteiramente fiel à filosofia bergsoniana -, mas da leitura tradicional da eternidade espinosana como um “sol do meio-dia”, o que faz dela algo estático - lógico - e incompatível, portanto, com a experiência. 
Reinstaurar a metafísica

A crítica bergsoniana à representação da realidade como um todo perfeitamente coerente e sistematizado (logicamente estruturado) é dirigida, na história dos sistemas d'A Evolução criadora, a todos os sistemas filosóficos por serem oriundos do procedimento cinematográfico do nosso entendimento, que se caracteriza pela reconstituição do movimento próprio às figuras (personalidades individuais) em um movimento impessoal e geral. Trata-se de uma recomposição artificial do movimento, por fora das coisas, sem que se leve em consideração o devir que é interior a elas. Da realidade que passa, nosso “aparelho cinematográfico” retém apenas vistas instantâneas cujo movimento é reconstituído em um “devir” abstrato e uniforme. Percepção, inteligência e linguagem, em geral, procedem assim (E.C., p. 305). A primeira nos coloca em contato com sólidos, a segunda os representa por meio de conceitos e símbolos, e a terceira fornece os próprios meios simbólicos de representação, possibilitando a sua expressão por palavras. Nos três casos, o que ocorre é uma recomposição do movimento com "vistas” ou elementos discriminados (isolados), por meio de uma espécie de cinematógrafo interior que é acionado. Isto ocorre porque "o mecanismo de nosso conhecimento usual é de natureza cinematográfica” (E.C., p. 305). Todos os sistemas filosóficos seguiram a mesma tendência natural (cinematográfica) e nenhum a questionou de fato como procedimento válido para a apreensão da realidade essencial ou do saber metafísico. Aqui estaria a origem não histórica (biológica) dos erros históricos. Mas, se os gregos deram início ao erro sistemático, podemos dizer que os modernos o evidenciaram, em diferentes momentos. Isto, porque, para Bergson, apesar de os gregos serem uma espécie de fonte primeira e derradeira de todos os sistemas, à qual todos tendem (“artistas incomparáveis”), teria havido na história dos sistemas filosóficos três momentos em que a filosofia poderia ter rompido com o mecanismo cinematográfico e com a filosofia antiga, início da transposição dos procedimentos práticos e utilitários para o plano da contemplação. Seriam, portanto, momentos não aproveitados, frustrados, desperdiçados na história da filosofia. As conclusões dos sistemas gregos (consequências do mecanismo cinematográfico comum a todos os sistemas filosóficos) são exigidas por uma recusa do devir que está inscrita num momento histórico em que o tempo era tomado a partir de suas "articulações naturais”, o que impedia a sua apreensão em "qualquer momento", porquanto o movimento era definido por conceitos como “alto” e "baixo”, "lugar próprio” ou "lugar alheio” - “momentos privilegiados ou salientes da história das coisas”, o que também definia as Formas ou Idéias platônicas e aristotélicas.

Com a ciência moderna, o tempo passa a ser considerado uma variável independente e todos 
os seus instantes são colocados no mesmo plano, não havendo momento essencial ou apogeu, e disto decorre que a "mudança não é mais uma diminuição da essência, nem a duração um protelamento da eternidade” (E.C., p. 371). Trata-se de uma transformação fundamental, pois o fluxo do tempo se torna a realidade. Mas, dessa realidade que flui, a ciência toma apenas “instantâneos”, não podendo proceder de outro modo, por ela ser de essência cinematográfica e a sua função é medir e calcular. Por essa razão, uma nova metafísica (um conhecimento de outra ordem) deveria completá-la, rompendo com a antiga, uma vez que esta não poderia apreender a nova realidade. Ciência e metafísica seriam (como devem ser, no entender de Bergson) duas maneiras de conhecer distintas e complementares, cabendo à primeira os “instantes”, e à segunda a própria duração. O que houve foi a reprodução, com base na nova física, do procedimento antigo, qual seja: "supor imediatamente consumado nosso conhecimento científico da natureza, unificá-lo completamente e dar a essa unificação, como já haviam feito os gregos, o nome de metafísica” (E.C., p. 372). Ao fazer isso, ela chega à conclusão imanente ao método cinematográfico: “Tudo está dado”. E isto porque a inteligência, como vimos, é quem organiza, ao mesmo tempo, os procedimentos da nossa atitude natural e o processo de abstração e simbolização que não é mais do que uma ampliação dessa atitude. Desse modo, a metafísica moderna substitui os conceitos diferenciados sobre a realidade pelo conhecimento matemático puramente relacional ${ }^{115}$, o que se inicia com Descartes e se aprofunda (no mecanicismo universal) com os seus discípulos. Ao fazer isso, ela também procede, como a antiga, à recusa do devir, mas não o faz porque, digamos, o momento assim o exige, mesmo porque as exigências históricas são outras. Ela procede por ignorância do momento histórico, não estando à sua altura. Nesse sentido, a metafísica permanece como um saber atemporal e a-histórico.

No segundo momento de frustração ou desperdício de uma possibilidade aberta a uma nova metafísica, a inteligência, na qual se dá o conhecimento relacional, de modo que o universo é definido por um sistema de leis, não é mais identificada com um ser infinitamente superior ao homem, que fundaria a materialidade das coisas e as ligaria entre si - o Deus leibniziano ou o espinosano -, e se torna a inteligência propriamente humana, o que significa que a ciência adquire um caráter relativo, ainda que se trate de uma humanidade divinizada e de uma relatividade

115 "Para os antigos, com efeito, a ciência portava sobre conceitos, ou seja, sobre espécies de coisas. Comprimindo todos os conceitos em um único, eles chegavam necessariamente, portanto, a um ser. [...] Deus é a síntese de todos os conceitos, a idéia das idéias. Mas, a ciência moderna apóia-se em leis, em relações. Ora, uma relação é uma ligação estabelecida por um espírito entre dois ou vários termos. Uma relação não é nada fora da inteligência que relaciona. O universo só pode ser, portanto, um sistema de leis se os fenômenos passarem pelo filtro de uma inteligência” (E.C., p. 356). 
absolutizada $^{116}$. Esse momento corresponde a um novo fracasso, porque uma vez mais se fizeram presentes questões que poderiam suscitar uma filosofia intuitiva, capaz de inverter a direção da inteligência e captar a duração, e mais uma vez o pensamento se perdeu nos descaminhos da inteligência errante. Isto porque, apesar de afirmar, contra seus predecessores imediatos, que o conhecimento não pode ser totalmente resolvido em termos de inteligência, abrindo "caminho para uma nova filosofia, que se teria instalado na matéria extra-intelectual do conhecimento por um esforço superior de intuição” (E.C., p. 357), Kant manteve a crença em uma ciência una e integral, abarcando a totalidade do real. Se, por um lado, ele demonstrou o caráter aporético da metafísica, por estar vinculada à intuição intelectual, por outro, acreditou que pensar consiste em seguir a tendência de solidificação da mobilidade por meio de Idéias. Para Bergson, a Crítica da razão pura é uma crítica da "razão afeita aos hábitos e exigências do mecanicismo cartesiano ou da física newtoniana”, não da razão em geral (M., p. 493). O que ele fez foi diminuir o dogmatismo de seus predecessores, aceitando sua concepção de ciência e reduzindo ao mínimo o que ela implicava de metafísica (E.C., p. 357). Tal se deve ao fato de que, para ele, a matéria extra-intelectual do conhecimento deveria ser co-extensiva à inteligência ou mais estreita que ela, recebendo dela a sua forma ou sendo por ela ordenada. Como não fez a crítica das pretensões da ciência, ele "aceitou sem discussão a idéia de uma ciência una”, e isto por acreditar que a inteligência cobre toda a extensão da experiência, o que exprimiu dizendo que "todas as nossas intuições são sensíveis, ou, em outros termos, infra-intelectuais” (E.C., p. 359). Por isso, criticou a metafísica (inviabilizando-a como conhecimento teórico) e a possibilidade de uma intuição supra-intelectual por meio da qual o espírito, no entender de Bergson, poderia tomar posse de si mesmo, não se restringindo a um conhecimento exterior e fenomênico, e fazendo com que a própria intuição sensível atingisse também um absoluto ${ }^{117}$. A crítica bergsoniana ao pensamento kantiano pretende uma redefinição do que se considera um "saber teórico”, restaurando a possibilidade da metafísica. A esse respeito, lemos em Bergson: intuição e discurso filosófico que:

116 Tudo fica "suspenso" a ela, de modo que o conhecimento relativo torna-se um absoluto. "Ela [a inteligência] não faz parte precisamente do homem; é, antes, o homem que está nela, como numa atmosfera de intelectualidade que sua consciência respiraria. É, se preferirmos, um Deus formal, alguma coisa que não é ainda divino em Kant, mas que tende a se tornar. Isso ficou claro com Fichte” (E.C., p. 356).

117 "Se essa intuição existe, uma tomada de posse do espírito por si mesmo é possível, e não mais somente um conhecimento exterior e fenomenal. Ainda mais: se temos uma intuição desse gênero, quero dizer ultra-intelectual, a intuição sensível certamente está em continuidade com ela, por certos intermediários, como o infravermelho com o ultravioleta. A própria intuição sensível irá, portanto, se elevar. Ela não atingirá mais simplesmente o fantasma de uma inapreensível coisa em si. É também no absoluto (desde que lhe sejam feitas algumas correções indispensáveis) que nos introduziria” (E.C., p. 359). 
O paradigma cartesiano exigia, para o conhecimento, que o objeto externo se colocasse à altura da interioridade, e isto fazia com que o conhecimento ficasse suspenso à idealidade objetiva. Kant exige que todo conhecimento esteja à altura da exterioridade suspensa à idealidade transcendental. Bergson critica ambas as posições em nome de uma continuidade entre interioridade e exterioridade, continuidade esta que não atribui a nenhum dos dois termos valor absolutamente fundante. [...] E por isto também a restauração bergsoniana da possibilidade da metafísica é na verdade uma reinstauração da metafísica. Esta reinstauração parte precisamente da crítica da ruptura absoluta entre intuição sensível e intuição intelectual. [...] Isto porque a experiência em seu sentido originário é experiência integral; tratase de encontrar esta origem para além ou aquém do significado pragmático que é a experiência organizada em função da percepção e da inteligência. [...] Por isto a crítica da inteligência como órgão especulativo inclui a crítica do criticismo como uma de suas mais acabas figurações históricas ${ }^{118}$.

Para Bergson, é possível e legítima uma intuição não-sensível, que se desenvolva aquém ou além dos fenômenos dados na experiência comum. Uma intuição não-sensível e também nãointelectual é possível desde que não seja uma intuição transcendente ou que vise uma transcendência: ela capta o que há de mais imediato, encontrando nele a própria razão do sensível, uma vez que o que se apreende é a continuidade entre interioridade e exterioridade, entre tensão e distensão (direções da duração). No texto Introdução à metafísica, de 1903, Bergson expõe essa mesma crítica ao kantismo, a qual será retomada n'A Evolução criadora ${ }^{119}$, no contexto dos momentos desperdiçados na história dos sistemas filosóficos, contrapondo à Crítica a experiência integral, como explicado na citação acima, e à qual voltaremos adiante. Por ora, o que queremos ressaltar é a idéia de "introdução à metafísica”, pois ela significa fundamentalmente introdução a uma metafísica que possa se desembaraçar da crítica kantiana, ou melhor, estar imune a ela, sem que tenha de ir na mesma direção das filosofias alemãs da primeira metade do século XIX, pois elas, pretendendo superar a crítica, mantiveram-se, na verdade, na direção natural da metafísica tradicional. Não se trata, portanto, de uma introdução à metafísica bergsoniana apenas, mas de uma reinstauração da metafísica como conhecimento teórico e isto porque, ao mesmo tempo em que Bergson pretende restaurar a possibilidade da metafísica, tal só pode ser feito se houver uma refundação da metafísica, visto que ela precisa ser instaurada ou fundada sobre novas bases (novo método e novo objeto,

118 Franklin Leopoldo e Silva, op. cit., p. 79-80. Devemos parte de nossa compreensão sobre a crítica bergsoniana ao criticismo kantiano a esse livro, do qual também assimilamos a expressão reinstauração da metafísica.

119 Claro está que o diálogo com Kant se inscreve também em outros momentos da obra de Bergson, como no Ensaio sobre os dados imediatos da consciência, cujo capítulo II é diretemente voltado para a crítica da noção de "grandeza intensiva” kantiana e seus desdobramentos, como apontamos na nota 2 do primeiro capítulo. 
distintos dos da ciência ${ }^{120}$ ), invertendo a tendêncida da inteligência e, portanto, imunizando-se do erro sistemático, do qual as filosofias pós-kantinas não escaparam. Para tanto, a crítica das ilusões, oriundas das antigas bases sobre as quais a metafísica tradicional se assentava, é essencial e parte do próprio processo. Ao tratar do criticismo kantiano, o que Bergson percebe é que ele não mudou as bases propriamente ditas do conhecimento, caindo também nas armadilhas geradas pelas ilusões da inteligência. O seu mérito, como crítico do caráter aporético da metafísica, é reconhecido por Bergson $^{121}$, constituindo um momento de abertura do pensamento, e abertura a um novo pensamento, cujas vias ele mesmo fechou. Vítima da ilusão natural à inteligência, contestou que nosso espírito pudesse atingir o absoluto, relativizando o conhecimento ao mesmo tempo em que o transformava em um procedimento absoluto, ao qual tudo estaria suspenso. Dissipada a ilusão, metafísica e ciência se vêem, ao contrário do que Kant imaginou, aptas a captar o absoluto ${ }^{122}$. Ao rejeitar as teses sustentadas pelos filósofos e aceitas pelos cientistas quanto à relatividade do conhecimento e à impossibilidade de se atingir o absoluto, Bergson tem em mente, na história d'A Evolução criadora, Kant e Spencer, e aqui entramos no terceiro momento malogrado na história dos sistemas. Após abordá-lo, retornaremos aos problemas deixados pela Crítica e à tentativa de superação das suas interdições, pelos pós-kantianos, de modo a mostrar como Espinosa ainda está presente nesse debate, necessário para a reinstauração da metafísica.

Sabemos que Bergson, em sua juventude, fora bastante envolvido pelo pensamento de Spencer, o qual exerceu uma influência considerável sobre a filosofia do século XIX ${ }^{123}$. Este século reclamava uma filosofia “capaz de descer ao detalhe dos fatos particulares” ou de "se instalar no que chamamos de duração concreta”, o que, em princípio, a "evolução spenceriana” se incumbira de realizar, mas também não o fizera, pois “mal se tinha engajado nessa via e deu uma guinada” (E.C.,

120 “Assinamos, portanto, à metafísica um objeto limitado, principalmente o espírito, e um método especial, a intuição, antes de tudo. Por aqui, distinguimos nitidamente a metafísica da ciência. Mas, por aqui também lhes atribuímos um valor igual. Cremos que elas podem, uma e outra, tocar o fundo da realidade” (P.M., p. 33).

121 Para Bergson, as pretensões metafísicas que se desenvolveram na história fizeram da filosofia um campo de batalha entre escolas opostas, o que o faz partilhar da exigência kantiana de um solo firme a partir do qual possam ser estabelecidos os "prolegômenos a toda metafísica futura que queira se apresentar como ciência”. O que Bergson não aceita de nenhum modo na crítica de Kant à metafísica é que, para o filósofo da ilustração, as dificuldades inscritas no conflito entre escolas distintas não se referem apenas ao fato de elas constituírem vários pontos de vista antinômicos da realidade, mas são inerentes à própria pretensão da metafísica. "Reencontramos um motivo fundamental da crítica bergsoniana de Kant: este aceita sem questionar que o ideal tradicional de conhecimento metafísico esgota a possibilidade da metafísica; portanto a metafísica futura morre na explicação dos seus prolegômenos” (cf. Bergson: intuição e discurso filosófico, p. 79).

122 "O mérito do kantismo foi o de desenvolver, em todas as suas consequências, e de apresentar sob a sua forma mais sistemática, uma ilusão natural. Mas, ele a conservou; é sobre ela que ele repousa. Dissipemos a ilusão: nós restituímos pelo espírito humano, pela ciência e pela metafísica, o conhecimento do absoluto” (P.M., p. 69).

123 A esse respeito, conferir o testamento autobiográfico do filósofo, ou seja, as duas introduções de $O$ pensamento e o movente. 
363). Tratava-se de um momento histórico em que novas ciências surgiam, e outras se desenvolviam, com questões e exigências também novas, ou seja, “o advento das ciências morais, o progresso da psicologia, a importância crescente da embriologia dentre as ciências biológicas, tudo isto deveria sugerir a idéia de uma realidade que dura interiormente, que é a própria duração” (E.C., p. 362). Bergson, no início, via Spencer como um contraponto ao kantismo dominante em sua época. Contudo, examinando a mecânica spenceriana, percebeu a ineficácia das definições tradicionais do movimento, às quais sua mecânica fazia coro. Isto o determinou a buscar um "verdadeiro evolucionismo", sendo A Evolução criadora a realização desse projeto, tempos depois da sua frustração com o sistema de Spencer. Ao final do livro, Bergson aponta algumas dessas mudanças de perspectiva na ciência, que novamente exigem uma "filosofia à altura", tais como as que a nova física revelava. Ele a interpreta como a afirmação de uma indeterminação dos fenômenos elementares devido às próprias coisas e não ao espírito que as concebe, e também como uma ciência que questiona, por exemplo, a concepção tradicional do átomo, tomando-o por um movimento (“turbilhão”) em que nem a criação nem a aniquilação são inadmissíveis. Se, contudo, tal ciência mantém certa noção de átomo como "suporte”, pois se trataria ainda de um "meio imponderável através do qual a energia e o movimento circulam”, o "filósofo deve ir mais longe que o cientista" (E.C., p. 368) e renunciar a essa noção, o que implica uma caracterização metafísica da matéria como puro movimento - e não apenas física ${ }^{124}$. Claro está que o filósofo não deve ir "mais longe” na mesma direção da ciência, e sim que se trata de uma direção inversa. Desse modo, ele, "fazendo tábua rasa do que é apenas um símbolo imaginativo, verá o mundo material se resolver num simples fluxo, numa continuidade de escoamento, num devir” (E.C., p. 368). Não há problema na direção da ciência, pois no que se refere à matéria bruta, "podemos negligenciar o escoamento sem cometer erro grave”, e o trabalho do cientista se refere a essa realidade, "lastreada de geometria”, tal como voltamos a ler ao final do livro, durando, todavia, por sua solidariedade com a outra dimensão do absoluto: a vida e a consciência. Assim, o verdadeiro evolucionista é aquele que se volta para o modus vivendi pelo qual a inteligência adotou seu plano de estrutura e a matéria seu modo de subdivisão (E.C., p. 367), investigando o processo que deu origem a ambos por uma complementação recíproca, posto que a estrutura da primeira e a subdivisão da segunda engrenam-se uma na outra. Ele compreende a evolução como tempo, o que significa que a realidade não é sempre a mesma em sua totalidade, porque ela não é totalidade - apenas pode ser definida assim se se tratar

124 A esse respeito, lemos na segunda introdução d'O pensamento e o movente que: "Seria bom se abster de toda representação imaginada do átomo, do corpúsculo, do elemento último qualquer que seja: era uma coisa servindo de suporte ao movimento e às mudanças, e, consequentemente, algo que em si mesma não mudava ou que não se movia 
de uma totalidade aberta ${ }^{125}$, nunca pronta e acabada, e sempre em vias de constituição. Spencer não é um verdadeiro evolucionista porque seu método “consiste em reconstituir a evolução com fragmentos do evoluído": não trata do processo, que é necessariamente temporal, mas dos resultados da evolução. O seu erro consiste em estender os procedimentos de explicação que tiveram êxito com a matéria interte para as “coisas da vida”. Vê a inteligência, em princípio, como um efeito local da evolução e, depois, "transforma essa lanterna manobrada no fundo de um subterrâneo em um Sol que iluminaria o mundo” (E.C., p. VII). Operando conceitualmente em uma reconstrução ideal de todas as coisas e da vida, desemboca, no entender de Bergson, em dificuldades e contradições, a ponto de renunciar à sua ambição de recompor a própria realidade, contentando-se em uma imitação do real ou, de preferência, com a sua imagem simbólica. Desse modo, ele é levado à mesma conclusão de Kant, qual seja: “a essência das coisas nos escapa e nos escapará sempre, movemo-nos em meio a relações, o absoluto não é de nossa alçada, detenhamo-nos diante do Incognoscível” (E.C., p. VII).

A razão de tais malogros sistemáticos (cartesiano, kantiano e spenceriano) está em que a inteligência nunca fora interrogada por uma crítica que procurasse sua origem, de modo a, sendo o caso, questionar o seu alcance. O seu limite está nela mesmo, ou seja, não é feita para captar o absoluto temporal, o que não significa que não possa captar o espacial - seu conhecimento é limitado, mas não relativo. Para Bergson, uma verdadeira evolução ou uma metafísica positiva digna desse nome, não sendo mais uma sistematização da ciência - não nega o absoluto nem parte dele: esforça-se por encontrá-lo, convive com ele, capta-o e vê que tudo está nele, que "no absoluto somos, circulamos e vivemos” (E.C., p. 200). Contra os resultados do pensamento spenceriano e kantiano, o absoluto poderá ser apreendido por uma metafísica que dialogue com a ciência, mas que não seja a sua versão última ou superior, como na metafísica moderna. Há, no processo bergsoniano de reinstauração da metafísica, uma retomada do que foi perdido na história da filosofia: trata-se de restaurar a metafísica como conhecimento teórico, com a ciência de sua época - mais complexa em relação à moderna -, escapando das objeções kantianas, e, consequentemente, de fundá-la sobre novas bases, o que os modernos "poderiam ter feito" e não fizeram. Bergson havia chamado a atenção para essa metafísica positiva na discussão ocorrida na Sociedade de Psicologia, em maio de 1901, cujo tema era justamente “O paralelismo psicofísico e a metafísica positiva”. A exposição prévia do filósofo a esse respeito procurava mostrar que cabia à experiência qualquer decisão sobre

\footnotetext{
por si mesmo. Cedo ou tarde, pensamos, seria preciso renunciar à idéia de suporte” (P.M., p. 77).

${ }^{125}$ Sobre a idéia de "totalidade aberta", conferir o artigo de Franklin Leopoldo e Silva, "Ontologia e liberdade em $A$ evolução criadora: A criação”. In Henri Bergson: crítica do negativo e pensamento em duração, p. 30.
} 
o paralelismo, de modo a nos revelar cada vez mais a relação do homem pensante com o homem vivente e, assim, a nos ensinar sobre o que se pode chamar de significação da vida (M., p. 464) expressão que comporá o título do terceiro capítulo d'A Evolução criadora. Se a fé no paralelismo surgiu e se manteve em virtude da crença de Leibniz e de Espinosa em um mecanicismo universal, levando-os a postular um encadeamento rigoroso de causas e efeitos, de modo que o espírito e o corpo dissessem exatamente a mesma coisa em duas línguas diferentes, Bergson se pergunta se eles teriam "hoje” a mesma idéia de ciência e se conceberiam a inteligibilidade da mesma maneira. Nessa ocasião, o filósofo esclarece o seu projeto, anunciando, cremos, a "Introdução à metafísica” no sentido em que supramencionamos, qual seja, como inauguração que é uma reinstauração da metafísica, tal como lemos:

Eu dizia, há pouco, que pretendemos continuar a obra dos cartesianos, mas levando em conta a maior complexidade da ciência atual. Eu acrescentaria, agora, que esse método pretende escapar às objeções que Kant formulou contra a metafísica em geral, e tem por principal objeto retirar a oposição, estabelecida por Kant, entre a metafísica e a ciência, levando em conta as novas condições em que a ciência trabalha (M., p. 493).

Continuar a obra dos cartesianos e não dos pós-kantianos. A oposição kantiana se sustentava na separação entre intuição intelectual e intuição sensível, de modo que só o que se apresentava à intuição sensível era passível de conhecimento teórico, como vimos. Ao se confrontarem com a interdição kantiana, os sucessores de Kant se elevaram a uma intuição intelectual e, mesmo dando amplo espaço ao devir, acabaram caindo no erro sistemático acima mencionado. Por isso, Bergson os menciona, ao final da análise do segundo momento frustrado em relação à possibilidade de uma nova metafísica, considerando que não constituiriam um momento diferente, no qual uma metafísica verdadeiramente nova e intuitiva teria sido possível. O problema talvez esteja na própria tentativa de superação da Crítica. Seria como uma tentativa de vencer uma guerra já perdida por erro estratégico, mantendo a mesma estratégia. Ao tentar restabelecer a intuição intelectual, o que os idealistas fizeram, no entender de Bergson, foi recair na tendência que levara à negação kantiana da metafísica e à afirmação da intuição sensível como única fonte de conhecimento teórico. Na verdade, a estratégia bergsoniana não está no confronto com a Crítica. Ultrapassá-la significa não se colocar no mesmo domínio que ela, e isto não porque ela não possa ser vencida nele, mas porque se trata, no fundo, do próprio domínio que deveria ser criticado: Kant não questionou se o ideal tradicional do conhecimento metafísico esgotava a possibilidade da própria metafísica e não interrogou o procedimento que deu origem a ele. Mesmo que os pós-kantianos tenham se voltado para “idéias de 
devir, de progresso, de evolução”, as quais “parecem ocupar um grande espaço em suas filosofias”, sendo bastante severos com as teorias mecanicistas, eles aceitaram, no entender de Bergson, a idéia de uma ciência una, a mesma para toda e qualquer realidade, negando toda ação eficaz à duração real. O problema está no fato de terem se orientado na direção de uma intuição intemporal na tentativa de escapar do relativismo kantiano e, desse modo, "voltaram ao espinosismo”, “deduzindo todas as formas de um Ser global supostamente dado” (E.C., p. 361). Ora, essa tentativa malograda de escapar do relativismo kantiano demonstra que os adversários verdadeiros de uma nova metafísica são, por diferentes razões: o próprio Kant e Espinosa, que elevou ao extremo a tendência própria à inteligência e, consequentemente, a metafísica por ela edificada. Não apenas Descartes e os cartesianos giram em sua órbita, como também os pós-kantianos. Para reinstaurar a metafísica será preciso escapar do relativismo kantiano e do absoluto espinosista. Assim, não nos parece estranho que, em outros momentos, Bergson tenha colocado Espinosa ao lado dos idealistas alemães, suscitando um anacronismo proposital. Logo no início da segunda introdução de $O$ Pensamento e o movente, o filósofo, esclarecendo os motivos pelos quais hesitara em chamar de "intuição" o seu método, enfatiza o que a faz radicalmente diferente da intuição, por exemplo, de Schelling ou de Schopenhauer: a deles é apenas “uma busca imediata do eterno”. Para Bergson, uma intuição do eterno ou do intemporal é sempre uma intuição cativa da inteligência pragmática. Assim, lemos no mesmo texto que

\begin{abstract}
Aos conceitos que a inteligência fornece, ela [essa intuição] substitui simplesmente um conceito único, que os resume todos, e que é, por consequência, sempre o mesmo, independentemente do nome com que o chamamos: a Substância, o Eu, a Idéia, a Vontade. A filosofia assim entendida, necessariamente panteísta, não terá trabalho em explicar dedutivamente todas as coisas, já que ela se terá dado de início, em um princípio que é o conceito dos conceitos, todo o real e todo o possível (P.M., p. 26).
\end{abstract}

Não é a primeira vez que Bergson caracteriza os filósofos do idealismo alemão como panteístas. Na "Introdução à metafísica”, ele também os designara “panteístas alemães”. Trata-se, sem dúvida, tanto aqui quanto no texto d'A Evolução, em que eles são acusados de voltarem ao espinosismo, de uma alusão à “querela do panteísmo”126, a partir da qual todo o racionalismo moderno - em que estará incluído o idealismo alemão - será acusado de voltar à doutrina de Espinosa, a mesma para a qual todo “o real e o possível” são dados de início, como vimos acima,

126 A esse respeito, conferir o próximo capítulo. 
pela maneira como relacionam o método geométrico e o conteúdo da metafísica pelo desdobramento autoprodutivo da substância ou do ens causa sui.

Esses “panteístas alemães” permaneceram impregnados de espinosismo e de kantismo, pois voltaram ao Ser global espinosista ao mesmo tempo em que aceitaram ou não escaparam da problemática kantiana, de modo que, no mesmo texto de $O$ Pensamento e o movente, lemos ainda que

\begin{abstract}
Nós o dizíamos acima: que se dê o nome que se quiser à 'coisa em si', que se faça dela a Substância de Espinosa, o Eu de Fichte, o Absoluto de Schelling, a Idéia de Hegel, ou a Vontade de Schopenhauer, por mais que a palavra se apresente com sua significação bem definida, irá perdê-la, esvaziar-se-á de toda significação assim que for aplicada à totalidade das coisas. [...] Aqui está o vício dos sistemas filosóficos. Acreditam nos informar sobre o absoluto conferindo-lhe um nome (P.M., p. 49).
\end{abstract}

A primeira ocorrência de uma crítica aos sistemas filosóficos na obra de Bergson acontece na "Introdução à metafísica”, a qual é permeada pelo debate com o idealismo alemão e com Kant. Posteriormente, na história dos sistemas filosóficos d'A Evolução, a mesma crítica ao idealismo alemão é direcionada contra Espinosa e a esses “sucessores de Kant”, cujo cerne é a contestação do princípio sobre o qual todo sistema se apóia: a identidade entre o princípio da realidade e o do conhecimento, ou a consideração de um "topo do ser" com o qual se faz coincidir o "topo do conhecimento", como também lemos no texto de O pensamento e o movente”, na sequência à exposição do “vício dos sistemas filosóficos” (P.M., p. 50). Tal coincidência faz de todo o resto realidade sensível e experiência temporal - uma degradação do imóvel em direção ao nada que o espreita, assim como desconsidera o conhecimento efetivo em virtude de uma "verdade já virtualmente conhecida”. Na sequência desse último texto que citamos, Bergson expõe o princípio que norteia a sua crítica e que é, digamos, novamente uma subversão crítica, ou melhor, uma subversão da Crítica, a saber: “A verdade é que uma existência só pode ser dada em uma experiência” (P.M., p. 50). Esta não se restringe à experiência sensível, dada a partir das formas $a$ priori do espaço e do tempo tal como em Kant, e o conhecimento que dela podemos ter é uma "lista sempre aberta”, uma vez que o que aqui se apresenta é “a experiência como jorro de fatos que se prolonga indefinidamente” (E.C., p. 360). À redução pragmática da experiência, Bergson contrapõe a experiência integral à qual os conceitos não aderem ${ }^{127}$. Por um lado, trata-se de recusar o tempo

127 A crítica bergsoniana à linguagem não significa a negação do discurso filosófico. A esse respeito, conferir o livro, já mencionado, do professor Franklin Leopoldo e Silva, Bergson: intuição e discurso filosófico. Uma "metafísica 
como "forma a priori da intuição pura" e o conhecimento mediato kantiano, afirmando o conhecimento do imediato ou do absoluto, e, por outro, de contestar os sistemas que aceitaram o problema tal qual ele é posto pela linguagem, ou melhor, pelos conceitos “incluídos nas palavras” e, “o mais das vezes, elaborados pelo organismo social em vista de um objeto que não tem nada de metafísico” (P.M., p. 51). Ao tentarem dizer o que é a "coisa em si”, incognoscível para Kant, os filósofos mencionados (Espinosa anacronicamente e os idealistas alemães) apenas hipostasiaram um conceito, que elevaram a "princípio" e do qual deduziram todas as coisas. Para escapar do kantismo, é preciso, ao contrário, "ver a duração como o estofo da realidade e, por conseguinte, distinguir entre a duração substancial das coisas e o tempo espalhado em espaço” (E.C., p. 360).

O percurso que realizamos até aqui lança uma luz num aspecto decisivo da atitude bergsoniana, qual seja, a crítica à tradição metafísica é inseparável da crítica à noção de sistema. Se tomarmos, então, o percurso realizado, ele poderia ser resumido pela afirmação de que a sistematicidade da qual toda a tradição filosófica foi vítima é também uma ilusão constitutiva de nosso entendimento, quando ele depõe sua função prática para se colocar como faculdade teórica, de modo que a apresentação da filosofia em sistemas não é exterior à filosofia, uma vez que ela mesma tende a se apresentar como sistema. Mas, nessa história, há um momento em que uma mudança de direção se fizera anunciar: na “oscilação” presente em Descartes. Este teria renunciado à sistematicidade ao preservar a liberdade do espírito a despeito da ciência de seu tempo ${ }^{128}$, de modo que a sua modernidade está nessa ruptura com a concepção grega da filosofia. Logo, “continuar a obra dos cartesianos” é continuar, sobretudo, a obra de Descartes, antes do primeiro malogro filosófico, perpetrado pelos “discípulos” que retomaram a tendência sistemática da filosofia numa tentativa ilusória de superar a ilusão do nada. Poderia ser também, de certo modo, continuar a obra de Leibniz, uma vez que o finalismo é algo passível de “melhoramento" (como exposto em $A$ Evolução), podendo ser aperfeiçoado em um “finalismo verdadeiro”, que parte do impulso (coloca-o

verdadeira", tal qual Bergson reivindica, terá de "voltar" aos conceitos em dois sentidos: perseguindo os conceitos prontos, para expulsá-los de seu domínio, e criando conceitos com maior capacidade de aderência, mais flexíveis toda a questão está em diminuir a margem de extensão, procurando captar a tensão por um maior esforço de atenção às coisas. Esforço que constitui a busca intuitiva ou o método bergsoniano de conhecimento, o qual se distingue da dedução que, para Bergson, é um procedimento “de preguiçoso". "Ele [o filósofo] se deixará deduzir preguiçosamente as consequências segundo as regras de uma lógica retilínea...” (P.M., p. 121).

128 Vimos, no capítulo anterior, que Bergson considera Descartes um filósofo que, por “apreço à liberdade”, não transformou o determinismo em doutrina. "Assim, ao lado da nova via que a filosofia podia rasgar, a antiga permanecia aberta. Esta era a mesma pela qual a física caminhava. [...] Que a metafísica tenha hesitado de início entre as duas vias, isto não nos parece contestável. De um lado, Descartes afirma o mecanicismo universal. [...] Mas, de outro lado (e é por isso que o filósofo não foi até o fim dessas consequêncis extremas), Descartes crê no livre-arbítrio do homem. Ele superpõe ao determinismo dos fenômenos físicos o indeterminismo das ações humanas e, por conseguinte, ao tempo-comprimento uma duração na qual há invenção, criação, sucessão verdadeira” (E.C., p. 344345). 
no início), devendo "reconstituir ou antes abarcar" a realidade, que tem relevo e profundidade, em uma visão simples (E.C., p. 57). Mas o mecanicismo espinosista é certamente, na visão de Berson, algo para "largar” e não para “pegar”, nem mesmo para reformular. O mecanicismo considera apenas o aspecto similitude ou repetição e quanto mais se explicita a geometria que ele contém, tanto menos admite a criação de algo (E.C., p. 49). A causalidade mecânica e geomêtrica é incompatível com a criação, a qual se faz pela e na diferença que é própria da duração.

\section{A crítica da idéia do Nada contra a concepção espinosista do Ser}

A filosofia tende à sistematicidade porque seu alvo, desde os gregos, é abarcar numa visão única a totalidade das coisas. Neste sentido, para Bergson, filosofar significa unificar. Quer se trate de uma unificação da multiplicidade infinita das coisas individuais em certo número de conceitos - e destes em uma idéia única -, como no caso dos antigos mais especificamente, quer se trate de estabelecer relações de dependência recíproca, expressas por leis que podem ser cada vez mais gerais até desembocarem em um princípio único - a realidade sendo representada como uma totalidade pronta ou como um sistema coerente, o que, do ponto de vista bergsoniano, satisfaz inteiramente o nosso entendimento, pois “é na unidade perfeita que o entendimento encontra o seu repouso” (M., p. 1071). Ao mistério da existência se sobrepõe o consolo da imutabilidade e da eternidade - ao Nada, o Ser. Aprofundando a essência dessa unidade, compreende-se que se trata de "um substrato imóvel do movente”, uma “essência intemporal do tempo”, uma “eternidade de morte, a qual não é outra coisa que o movimento esvaziado da mobilidade que era sua vida” (P.M., p. 209; grifos nossos). Essa eternidade de morte é vazia de existência psicológica, porque é apenas conceitual e articulada de acordo com a necessidade lógica do pensamento matemático que, com Espinosa, desdobra-se e se projeta na necessidade do Ser absoluto, como pontuado acima. Ao afirmar que o Absoluto “é de essência psicológica e não matemática ou lógica”, Bergson está dizendo que ele é temporal. O psicológico é a realidade do tempo e no tempo. A duração é o tecido da realidade porque nela todas as coisas são, o que não significa um substrato - não se trata de algo sob a mudança, mas da própria mudança -, e não deixa, contudo, de ser uma substancialidade.

A crítica à idéia do Nada é crítica da necessidade lógica, sem que isso signifique a queda no termo que lhe é contrário, a contingência. Claro está que Bergson afirma a contingência, dando-lhe uma dignidade negada pelos sistemas mecanicistas e finalistas, e isto não porque, negando o seu oposto, tenha de assumi-la, e sim porque, não se submetendo à oposição - entre contingência e 
necessidade -, não tem que escolher um dos termos em detrimento do outro. Novamente o que está em jogo, ainda que sob outra perspectiva, é a libertação filosófica dos dualismos, simetrias e oposições oriundas da estrutura da linguagem e da inteligência. O que a intuição capta é a diferença constitutiva das coisas, e ela não é negação ou oposição, é mais complexa do que isso. A eternidade identificada à necessidade lógica, consequência da sobreposição do Ser ao Nada, é a negação de toda e qualquer novidade ou criação no universo. Mas, a contingência bergsoniana não é o oposto simétrico de tal necessidade - a assunção de uma total gratuidade no mundo, a disseminação de uma contingência absoluta no universo. A duração é heterogeneidade e também continuidade. Embora o passado seja diferente do presente que ele foi - há uma diferença de natureza entre eles, e não de grau -, isto não significa uma total impenetrabilidade entre ambos - um novo presente não adviria se o antigo presente não passasse ao mesmo tempo em que é presente. Para que um presente passe, é preciso que ele seja, ao mesmo tempo, passado, do mesmo modo que o passado jamais se constituiria se não tivesse se constituído inicialmente. O presente não só coexiste com o passado, como é o nível mais contraído dele. A noção bergsoniana de contração ou de tensão permite a ultrapassagem dos dualismos - heterogêneo e homogêneo, presente e passado, necessidade e contingência -, recuperando uma unidade ontológica ${ }^{129}$ que em nada se assemelha à unidade tradicional. Esta, representada na maior parte das vezes sob forma arbitrária e geométrica, é fruto, como vimos, da "convicção de que a natureza é una e de que a inteligência tem a função de abarcá-la inteiramente”, cabendo a Espinosa, mais do que a qualquer outro,

hipostasiar a unidade da natureza ou, o que dá no mesmo, a unidade da ciência, em um ser que não será nada já que não fará nada, em um Deus ineficaz, que resumirá simplesmente em si a totalidade do dado, ou em uma Matéria eterna, do seio da qual verteriam as propriedades das coisas e as leis da natureza, ou ainda em uma Forma pura que procuraria apreender uma multiplicidade inapreensível e que será, como se preferir, forma da natureza ou forma do pensamento” (E.C., p. 198).

A essa unidade factícia, imposta pelo entendimento - construída "por fora” da natureza -, Bergson substitui uma “unidade verdadeira, interior e viva” (E.C., p. 200), uma continuidade de elementos múltiplos, qualitativamente distintos, que se prolongam uns nos outros. Se se pode falar em unidade, tal se deve ao fato de que esse termo adquire outro sentido na filosofia bergsoniana. Unidade não se opõe aqui à multiplicidade (novamente, as dicotomias estéreis da tradição são

129 Deleuze considera que, ao colocar as diferenças de grau na própria duração - diferenças de distensão e de contração - , Bergson funda a possibilidade de um novo monismo (Cf. Bergsonismo, p. 58). 
negadas). A unidade é múltipla e a multiplicidade é una porque se trata de uma multiplicidade qualitativa, e não da abstração dos números. Trata-se de uma continuidade de mudança, e o melhor modo de apreendê-la, segundo Bergson, é nos instalarmos diretamente, por um esforço de intuição, na fluidez concreta da duração (P.M., p. 210).

Porque, “em nenhuma parte, a substancialidade da mudança é tão visível e tão palpável como no domínio da vida interior” (P.M., p. 165), é nela que devemos primeiramente nos instalar para, a partir dela e com ela, entrarmos em contato com as outras durações. Isto é importante porque, nessa perspectiva, o que o filósofo coloca como ponto de partida é o que as doutrinas filosóficas, à medida que se tornam sistemáticas, acabam por desprezar: a individualidade (diluída no Todo) ou, em termos mais bergsonianos, a personalidade dos viventes ${ }^{130}$. Para Bergson, as dificuldades e contradições, às quais chegam as teorias da personalidade, devem-se ao fato de a representarem como uma multiplicidade de estados (invariáveis) apenas ou como uma unidade que lhes serviria de suporte. Em nenhum dos casos, contudo, se pode constituir um eu que dura. A duração própria à personalidade é algo como uma unidade melódica: singularidade de uma sinfonia que não pode ser encurtada ou apressada, e em que os sons penetram-se uns nos outros numa sucessão contínua e diferenciada ${ }^{131}$. Em lugar de um substrato pelo qual os estados distintos passariam, Bergson define a personalidade como “a melodia contínua de nossa vida interior”, que se desenrola do início ao fim de nossa existência, de modo que há uma unidade que não é composta de partes externas umas às outras, nem há um suporte pelo qual os estados passariam. Assim,

A personalidade, como ela se revela ao exame, é, nós vimos, uma continuidade de mudança. [...] Essa continuidade de mudança causa o que chamamos de a permanência, a unidade, a substancialidade da pessoa. Durante a totalidade de sua existência, uma pessoa prolonga seu passado em seu presente, guarda tudo - na memória consciente ou inconsciente - e também acrescenta alguma coisa. Mas, não há nisso nada semelhante à adição de partes a partes. Por analogia, poderíamos falar de um fio elástico que se estenderia até um comprimento infinito sem jamais ser dividido, e que, de outra parte, pelo único fato de que ele aumenta o seu comprimento, poderia, ao mesmo tempo, aumentar o seu peso (M., p. 1080; grifo nosso).

\footnotetext{
130 “O problema da personalidade” é decisivo para Bergson tal como podemos ver no curso a ele dedicado (1914) e que se abre com a afirmação de que se trata do problema central para a filosofia (cf. M., p. 1071).

131 Para Bergson, enquanto a visão e o tato nos remetem mais propriamente ao mundo da ação e, portanto, da fragmentação, a audição é mais apta a nos fazer perceber o movimento e a mudança como realidades independentes. É a partir dessa diferenciação sensória que ele nos dá o exemplo da música como algo que nos permite captar a duração: "Teremos menos dificuldade em perceber o movimento e a mudança como realidades independentes se nos dirigirmos ao sentido da audição. Escutemos uma melodia deixando-nos adormecer por ela: não temos a percepção nítida de um
} 
De acordo com Bergson, essa unidade poderia ser dita "unidade múltipla ou multiplicidade una” porque necessitamos usar a linguagem do entendimento - é inevitável, porque “só o entendimento tem uma linguagem” -, o que não faz mais do que confirmar que unidade e multiplicidade são apenas, nesse caso, vistas tomadas da personalidade. Ao juntar esses termos contraditórios, o que se pretende, de um lado, é mostrar a insuficiência dos mesmos para a expressão da complexidade da existência, e, de outro, a vacuidade das disputas filosóficas que se deram pela defesa maior de um ou de outro. Com ambos, talvez se possa “dar uma imitação aproximativa dessa interpenetração recíproca e dessa continuidade que encontro no fundo de mim mesmo. Tal é minha vida interior e tal é também a vida em geral” (E.C., p. 359). A evolução da "vida em geral” é também comparada, por Bergson, a uma melodia do universo. O esforço intuitivo (metódico, portanto), pelo qual nos instalamos em nossa duração, coloca-nos também em contato com uma continuidade de durações, visto que se trata de uma mesma unidade melódica da qual as personalidades não só são parte como tomam parte, como veremos abaixo. Ele nos revela não o “já feito”, mas o “se fazendo”, o que, constituindo uma inversão do modo como tendemos naturalmente a ver o mundo, significa uma transcendência ou uma superação da condição humana. O que se revela no contato com a duração, com o processo temporal de criação de cada objeto, são as duas direções às quais ela tende: uma que, no limite, seria pura repetição, pela qual a matéria é definida; outra que, no limite, seria a eternidade, ou a tensão máxima da duração, a qual, por ser uma tendência inversa à repetição, podemos definir como pura diferenciação. Bergson a considera uma "eternidade de vida" radicalmente distinta da “eternidade de morte” conceitual. Nas suas palavras, trata-se de uma

Eternidade viva e, por conseguinte, ainda movente, na qual nossa duração se encontraria como as vibrações na luz, e que seria a concreção de toda duração como a materialidade é seu espalhamento. Entre esses limites extremos, a intuição se move e esse movimento é a própria metafísica (P.M., p. 210-211).

Distensão e contração são inversões um do outro, e não intensificações, sendo a matéria o grau mais distendido da duração - por isso há diferença de natureza entre elas (matéria e duração), e não diferença de grau. Partir da existência, dada apenas na experiência, para Bergson, é ver o Ser diretamente, sem o suporte imaginário do nada e da imobilidade, ou seja, é se colocar na plenitude da presença de modo a captar o processo temporal criador de cada coisa. Trata-se de captar a diferença uma vez que a duração é continuidade qualitativa, ou seja, diferenciação. Trata-se, portanto, de 
captar cada coisa em sua especificidade ou em sua singularidade.

Para resolver, ou melhor, dissolver os pseudos problemas da filosofia tradicional, Bergson reivindica outro ponto de partida: não mais colocar os problemas em função do espaço, mas da duração. Nesse caso, ao invés de buscar semelhanças nas coisas, de acordo com as quais os gêneros são constituídos e um modo de regularidade é estabelecido - característica do domínio espacial -, deve-se partir das diferenças, o que nos revela singularidades ou coisas naturalmente distintas característica do domínio temporal. Isto tanto no que se refere aos estados de nossa "vida interior” quanto à "vida em geral”. A personalidade em Bergson tem um sentido temporal e este critério permite que ele a estenda a todo ser vivo, mesmo àqueles em que se percebe o mínimo de singularidade (mais próximos do limite da duração que se define pela repetição). Cada organismo é um indivíduo ou uma singularidade não por causa de nossa percepção, mas nele mesmo, pelo período de tempo em que contrái e exprime sua história singular (sua “unidade melódica”). A função da metafísica é apreender essas contrações (histórias singulares) e por isso, o que caracteriza a intuição bergsoniana é a simpatia, o conhecimento “por dentro”, ou seja, temporal e psicológico. E, para ela, a linguagem não é uma condenação, e sim uma forma de superação, pois é capaz de perceber a pluralidade dos sentidos, sem que tenha de condensá-los em conceitos imobilizantes - ela lhes acrescentará a imagem, alargando-os, flexibilizando-os e demonstrando que eles não contêm a experiência inteira (P.M., p. 45).

Numa carta a Harald Hoffding, de 15 de março de 1915, Bergson chama a atenção de seu correspondente para a intuição e a duração tais como se apresentam em sua filosofia. Nas suas palavras,

Creio que, se se tem em conta o que entendo por duração, ver-se-á no "vitalismo" de A Evolução criadora algo mais preciso e também mais eloquente do que você diz. $\mathrm{O}$ argumento essencial que dirijo contra o mecanicismo em biologia é que ele não explica como a vida desenrola uma história, ou seja, uma sucessão em que não há repetição, em que todo momento é único e porta em si a representação de todo o passado. [...] De uma maneira geral, aquele que captou a intuição da duração não poderá jamais crer no mecanicismo universal; pois, na hipótese mecanicista, o tempo real se torna inútil e mesmo impossível. Ora, a duração é o mais indiscutível dos fatos para aquele que se coloca nela. É por isso que digo que ela nos fornece uma refutação empírica, definitiva, da filosofia mecanicista (M., p. 1149; o grifo longo é nosso).

Enquanto o falso evolucionista recompõe a evolução com fragmentos do evoluído, desconsiderando o papel do tempo como processo criador das estruturas com as quais se depara, o 
verdadeiro evolucionista apreende a evolução da vida como uma história e, neste sentido, mais que dizer que a natureza tem uma história, trata-se de considerar que ela é uma história. A evolução das espécies, nessa perspectiva, representa o que subsiste do jato original ou da impulsão criativa que lhes originou. No processo vital, o impulso criador se depara com obstáculos tais que, ao tentar superá-los, acaba por “girar ao redor de si mesmo”, “fechando-se” em determinadas espécies - só no homem esse processo não significa um fechamento, mas uma abertura, como veremos um pouco mais adiante. Mas, "por toda parte, é o mesmo tipo de ação que se realiza, quer se desfaça, quer procure se refazer”, e isto porque há, nas palavras de Bergson, "um mesmo centro de onde os mundos jorrariam como os foguetes de um imenso buquê - com a condição todavia, de que não se tome esse centro por uma coisa, mas por uma continuidade de jorro” (E.C., p. 249). Essas palavras do terceiro capítulo de A Evolução criadora são fundamentais porque com elas Bergson nos lança em direção ao princípio vital, que é a origem da vida, enquanto potência primitiva de criação, ao mesmo tempo em que demonstra (pelo exame de suas consequências) uma ilusão do entendimento (ver “coisas” e “estados” onde há movimento ou mobilidade) cuja origem (exame dos princípios) será buscada no capítulo seguinte, pelo que começamos este capítulo. Na imagem do elã vital, há uma dupla recusa bersgsoniana: a do mecanicismo ${ }^{132}$ e a do finalismo como formas de pensamento da vida. Ela é constituída por "fatos” indiscutíveis que levam a uma "refutação empírica, definitiva, do mecanicismo filosófico” ${ }^{133}$.

Para Bergson, é incompreensível que os filósofos da modernidade tenham chamado de Deus "um princípio que não tem nada em comum com o que a humanidade sempre designara com essa palavra” (P.M., p. 48). Tratar-se-ia de uma confusão entre uma idéia explicativa e um princípio ativo (P.M., p. 48). Ele teria sido hispostasiado na tentativa de solucionar uma vez mais o mistério da existência, estando fadado ao fracasso por essa mesma origem. Ora, na tentativa de vencer o nada, a filosofia antiga acabava por inverter a gênese de modo a afirmar o Ser e, a partir dele, retirar os graus de realidade intermediária entre ele e o puro nada ${ }^{134}$. No caso do Deus espinosista, totalidade

132 No caso do mecanicismo biológico, quem é visado paradigmaticamente é Spencer, mas a crítica também se volta para outros cientistas e suas escolas, tal como vemos no primeiro capítulo de A Evolução criadora, no qual Bergson dialoga e contesta algumas teses do neodarwinismo de Weismann, do mutacionismo de De Vries, da ortogênese de Eimer e do neolamarckismo francês.

133 O finalismo filosófico, também criticado no texto de A Evolução criadora, e ao longo de toda a obra de Bergson, é apresentado como um correlato do mecanicismo, cometendo um erro fundamental, que pode ser expresso na fórmula sempre citada quando Bergson trata do mecanicismo e à qual já fizemos referência, a saber: “Tudo está dado” (ainda que no finalismo, apresentado por Bergson em sua forma leibniziana, seja dado primeiramente um plano de acordo com o qual os elementos serão ordenados).

134 Tal é o caso do "Deus de Aristóteles", do qual seguem todos os "graus descendentes do ser da perfeição divina até o 'nada absoluto'”, de modo automático, bastando que Deus seja posto. Segundo Frédéric Worms: “Desse modo, a gênese do Ser pelo nada se disfarça em gênese do nada pelo Ser, mas é a primeira que é real, e o 'niilismo' não está na 
dada por leis implacavelmente necessárias, podemos dizer que, mais do que "surdo às preces” (P.M., p. 48), o que se apresenta é um Deus sem vida - ao invés de consolo, um desconsolo. Assim, fazemos nossas as palavras de Frédéric Worms a respeito da crítica de Bergson ao "Deus dos filósofos”, cuja gênese é o Nada, de acordo com as quais, “tudo se agrava em um círculo de certo modo infernal: a representação do vazio transforma-se na da morte em um mundo vazio, vazio de intenções favoráveis, vazio de sentido. É o caso de dizer que 'Deus está morto', mas ele está, por assim dizer, morto desde sempre, desde o primeiro olhar que nossa inteligência implacavelmente lógica e mecânica lança sobre o mundo imediatamente 'desencantado"'135.

Ao inverter essa lógica e colocar como ponto de partida a intuição da duração, ou seja, da existência dada na experiência, Bergson pode dissolver o mistério e a angústia da ausência ${ }^{136}$. Ou seja,

Deus, assim definido, não tem nada de inteiramente feito; é vida incessante, ação, liberdade. A criação, assim concebida, não é um mistério, nós a experimentamos em nós desde que agimos livremente (E.C., p. 249; grifo nosso)

Definição importantíssima para a compreensão da noção de elã que, por sua vez, é essencial na filosofia de Bergson. A ela voltaremos logo abaixo. Antes, porém, é necessário dizer que ela suscitou muitos ataques e mal-entendidos e também que, ao responder a eles, Bergson explicita quem é o seu adversário na crítica da idéia do Nada, ao mesmo tempo em que esclarece sua própria posição, de modo a deixar claro as diferenças de suas filosofias. A primeira e mais conhecida interpelação foi feita pelo padre Joseph Tonquédec, que se mostrou incomodado com o que considerou uma ambiguidade da definição de Bergson no sentido de não deixar claro se Deus é ou não imanente à criação. Bergson lhe responde em duas cartas, das quais citaremos alguns trechos importantes para o que expusemos tanto sobre a crítica de Bergson a Espinosa quanto sobre a própria filosofia bergsoniana. Na primeira, de 12 de maio de 1908, Bergson escreve:

Falo de Deus (pp. 268-272 de A Evolução criadora) como da fonte de onde saem sucessivamente, por um efeito de sua liberdade, as “correntes” ou “elãs”, dos quais cada um formará um mundo: ele permanece, portanto,

morte, mas no nascimento do 'Deus dos filósofos'” (conferir o artigo “Qual vitalismo para além de qual niilismo? De A evolução criadora a nossos dias” in Henri Bergson: crítica do negativo e pensamento em duração, p. 16).

135 Worms, F. “Qual vitalismo para além de qual niilismo? De A evolução criadora a nossos dias” in Henri Bergson: crítica do negativo e pensamento em duração, p. 16-7..

136 “Mistério” e “angústia” são termos do vocabulário do negativo, assim como “decepção", "falta” e "vertigem”. 
deles distinto e não é dele que se pode dizer que "frequentemente volta sobre si mesmo", ou que esteja "à mercê da materialidade que teve de se dar". Enfim, a argumentação pela qual estabeleço a impossibilidade do nada não é de nenhum modo dirigida contra a existência de uma causa transcendente do mundo: expliquei, ao contrário (pp. 299-301 e 323), que ela visa a concepção espinosista do ser. Ela pretende simplesmente mostrar que alguma coisa sempre existiu. Sobre a natureza dessa "alguma coisa”, ela não traz, é verdade, nenhuma conclusão positiva, mas não diz, de nenhum modo, que o que sempre existiu seja o próprio mundo, e o resto do livro diz explicitamente o contrário” (M., p. 766-767) ${ }^{137}$.

Na segunda carta, de 20 de fevereiro de 1912, lemos:

Não tenho necessidade de dizer que você é inteiramente livre para publicar a passagem da carta que lhe escrevi outrora, à qual faz alusão, e na qual precisei o sentido de duas ou três frases de $A$ Evolução criadora relativas à natureza de Deus... Você deseja me perguntar se tenho algo a acrescentar? Não vejo nada a acrescentar no momento, enquanto filósofo, porque o método filosófico, tal como o entendo, é rigorosamente calcado na experiência (interior e exterior) e não permite enunciar uma conclusão que ultrapassa, não importa quanto, as considerações empíricas nas quais se funda. Se meus trabalhos puderam inspirar alguma confiança aos espíritos que a filosofia tinha deixado, até então, indiferentes, é por esta razão: nunca dei nenhum lugar ao que era simplesmente opinião pessoal ou convicção capaz de se objetivar por este método particular. Ora, as considerações expostas em meu Ensaio sobre os dados imediatos da consciência levam a iluminar o fato da liberdade; as de Matéria e memória fazem tocar com o dedo, espero, a realidade do espírito; as de A Evolução criadora apresentam a criação como um fato: de tudo isto se depreende nitidamente a ideia de um Deus criador e livre, gerador, ao mesmo tempo, da matéria e da vida, e cujo esforço de criação continua, do lado da vida, pela evolução das espécies e pela constituição das personalidades humanas. De tudo isso se depreende, por conseguinte, a refutação do monismo e do panteísmo em geral. Mas, para precisar ainda mais essas conclusões e delas dizer algo a mais, seria preciso abordar problemas de um gênero completamente distinto, problemas morais. Não estou seguro quanto a algum dia publicar sobre esse assunto ${ }^{138}$. Só o farei se chegar a resultados que me pareçam também demonstráveis ou também "mostráveis" como os de meus outros trabalhos. Tudo o que diria no intervalo estaria de lado e mesmo fora da filosofia tal como a concebo; a filosofia sendo, a meus olhos, alguma coisa que se constitui segundo um método bem determinado e que pode, graças a esse método, pretender uma

137 Em comentários que escreveu ao texto de Albert Adès ("La philosophie de Bergson dans da vie", publicado na Grande Revue, no volume de fevereiro, março e abril de 1918), lemos algo muito próximo da resposta dada a Tonquédec: "Minha crítica à ideia de nada não se dirige de nenhum modo à ideia de Deus, mas contra uma concepção tal como a de Espinosa, por exemplo / 'Deus é inútil'. Isto é completamente contrário ao meu pensamento. Colocar o nada é tornar tão incompreensível a ideia de Deus quanto a do Universo” (M., p. 1303; grifo nosso).

138 Sabemos que o último livro de Bergson, As duas fontes da moral e da religião, se volta para essa problemática. 
objetividade tão grande quanto a das ciências positivas, ainda que de outra natureza” (M., p. 964; grifo nosso).

A primeira carta esclarece que Deus cria livremente “correntes” e “elãs” distintos dele. Ora, uma das teses mais importantes de A Evolução criadora é justamente a de que o princípio vital age por dissociação, ao contrário do que se costumava acreditar em biologia (associação). Por um lado, o filósofo explicita a diferença entre Deus e os elãs que dele saem, porque ele é a fonte ou a ação que não se prende ou se encerra nos volteios que a materialidade impõe, de modo a formarem mundos em distintas direções - e, desse modo, trata-se de um princípio transcendente. Nos diversos mundos criados, a materialidade se impõe de modo que, na maioria das vezes, ao tentar contornar os obstáculos, o princípio (em suas distintas ramificações) acaba por se fechar no automatismo. Mas, a fonte é algo distinto e não se esgota ou se prende nesses diferentes mundos. Por outro lado, a definição de Deus mostra que a “criação divina” é algo que podemos experimentar em nós mesmos, “desde que ajamos livremente”, o que significa que não só somos criadores como também participamos e expressamos o princípio divino, no sentido de que podemos “dar continuidade” a ele, deixá-lo fluir - e, assim, não somos mais distintos dele. Ora, o que está em jogo aqui é a conciliação entre liberdade e necessidade na evolução criadora ou na metafísica da vida. Bergson define a matéria inerte como sede da necessidade - o que a faz proceder mecanicamente e o que permite que a ciência atinja um dos lados da realidade ou do absoluto, como dissemos anteriormente. A vida é o domínio da ação e da liberdade, mas se vê compelida, muitas vezes, pelos próprios mecanismos que cria no esforço de conservação, a se prender ou se perder no automatismo. Ela é "uma tendência a agir sobre a matéria bruta” (E.C., p. 97), ao mesmo tempo em que, com ela, “aparece o movimento imprevisível e livre. [...] A vida é precisamente a liberdade se inserindo na necessidade e a dirigindo em seu proveito” (E.S., p. 13). Esses dois sentidos da noção de vida - a pragmaticidade, de um lado, e, de outro, a duração e a liberdade criadoras ${ }^{139}$ - contribuem para a refutação bergsoniana do monismo, como lemos na segunda carta citada, ainda que, no mesmo contexto, ele deixe claro que se trata de "um Deus criador e livre, gerador, ao mesmo tempo, da matéria e da vida” (grifos nossos). Nega o monismo, mas não nega a unidade do princípio criador e livre, porque, como vimos, trata-se de um novo sentido de unidade. "De tudo isso se depreende” também a refutação do panteísmo. Ora,

139 A vida se manifesta tanto pelos seus resultados (organismos e espécies submetidos ao constrangimento da ação sobre a matéria), quanto pelo elã e pela criação que portam - esta se encontra em toda consciência e em toda duração. A esse respeito, conferir o livro de Frédéric Worms, Le vocabulaire de Henri Bergson, p. 62. Do mesmo autor, conferir também Os dois sentidos da vida. 
Bergson considera que essa concepção da natureza, no que concerne à liberdade humana, tende ao determinismo. Considerando que nossos corpos são partes da matéria universal e que nossas almas são também fragmentos do espírito que anima o mundo, o panteísmo, de um modo geral, afirma que participamos do pensamento divino, mas tal se deve ao fato, no entender de Bergson, de que as decisões de nossas almas estão ligadas às decisões do espírito divino, o que significa a dissolução tanto das personalidades quanto das lembranças, que "as almas perdem” ao voltarem, com a morte, ao "grande Todo”. Nas cartas, vemos que o "Deus criador e livre” bergsoniano não está "à mercê da materialidade que teve de se dar” e que seu esforço de criação continua na constituição das personalidades humanas. No panteísmo, dar-se-ia o contrário: uma materialidade imperante e a inexistência das individualidades reais. A ontologia tal qual Bergson reinvidica, diferentemente, exige almas individuais com a sua realidade própria, ou a sua melodia singular, a qual não pode ser apagada - é memória que não se perde em função de nenhuma perturbação material, quer seja acidental (como no caso das afasias), quer seja fatal (com a morte). E se o esforço de criação divina continua nas personalidades humanas tal se deve ao esforço que elas próprias devem fazer no sentido de criação e apreensão da vida à medida que escapam do invólucro material (E.S., p. 19-22). Assim sendo, o homem é um “triunfo” da e na criação.

Ainda que também esteja sujeito ao automatismo, num momento de distensão ou de desatenção, “o homem triunfou” e isto "graças a esse maravilhoso instrumento que é o cérebro humano” (M., p. 486). Há nele uma superioridade, enquanto instrumento, em função da capacidade indefinida que ele tem de montar mecanismos que servirão a outros mecanismos, de modo que, enquanto nos animais a faculdade de contrair hábitos motores (instinto) é limitada, no homem, essa capacidade (inteligência) é ilimitada. Não é só um órgão de atenção à vida, mas também de libertação. Nada se encontra nele que corresponda às operações próprias ao pensamento, mas é ele que torna o pensamento humano possível e capaz de ultrapassar os seus limites primários. O cérebro é, de acordo com Bergson, um “órgão de esporte”, de atividade. “O primeiro de todos os esportes é a linguagem, essa função que ocupa um tão vasto território no cérebro do homem” (M., p. 486). Se a linguagem, por um lado, se caracteriza pela imobilidade ou cristalização dos significados (em palavras que acabam por amarrar o próprio pensamento), por outro, ela "fornece à consciência um corpo imaterial onde se encarnar” (E.C., p. 265). É que ela também possibilita certa maleabilidade que pode ser apreendida na dificuldade de adequação simbólica. Todo o trabalho da filosofia, por exemplo, estará na tentativa de superação da instrumentalidade da linguagem, recuperando, “o ato designativo para aquém de seu telos natural, isto é, antes que o movimento de significação se consuma na fixação de sentido”, e esta “é a única possibilidade de expressão metafórica da 
intuição" ${ }^{140}$. Assim, a linguagem pode ser um instrumento de superação. Há ainda, para Bergson, um terceiro meio pelo qual os homens triunfam (vencem o automatismo): a vida social. Diferentemente da sociedade dos animais, fechadas em seus hábitos ou funções determinadas e repetitivas, a sociedade humana se caracteriza pela abertura e criação de novas possibilidades coletivas (morais, por exemplo) $)^{141}$. Desse modo, lemos em A evolução criadora que nosso cérebro, nossa linguagem e nossa vida social "contam, cada um a sua maneira, o sucesso único, excepcional, que a vida obteve em um momento de sua evolução” (E.C., p. 265). Isto significa algo fundamental, pois, nas palavras de Bergson: "É nesse sentido inteiramente especial que o homem é o 'termo' e o 'objetivo' da evolução” (E.C., p. 265) - o que, como sabemos (pela própria crítica de Bergson ao finalismo) não significa um "projeto" ou "plano”. Significa que o homem continua indefinidamente o movimento vital $^{142}$. O “elã vital”, como Bergson o considera, é uma potência de vida. Essa noção, tal como aparece em A Evolução criadora, revela que ele constitui o tipo de causalidade própria à vida, o que é evidenciado pelo fato empírico da evolução (a criação das espécies e das formas vivas), podendo ser pensado adequadamente apenas pela analogia, por meio de imagens ${ }^{143}$, com a experiência psicológica do esforço. Ora, toda criação evidenciará esse princípio, ou seja, suporá uma tal impulsão - e isto vale, portanto, para a criação “de nossas intenções, de nossas decisões, de nossos atos, e por aí também de nossos hábitos, de nosso caráter, de nós mesmos” (P.M., p. 102). Desde o seu primeiro livro, Bergson considera os atos livres como expressão ou emanação da personalidade inteira $^{144}$. Esses atos são efeito do que somos e, ao mesmo tempo, causa do que somos, pois o que fazemos depende do que somos, mas o que somos depende também do que fazemos (E.C., p. 7).

140 A esse respeito, conferir o livro do professor Franklin Leopoldo e Silva, Bergson: intuição e discurso filosófico, no qual lemos ainda que: “a tentativa de superação da instrumentalidade só poderá consistir em impedir que tal instrumentalidade se consolide a partir da intencionalidade pragmática da inteligência, fazendo com que a linguagem se detenha no seu movimento: fazendo com que a interioridade deixe de ser apenas o impulso inicial para que os atos de designação se realizem na exterioridade e torne-se o campo em que os atos metafóricos exprimam-se como tais, o que significa um início de expressão da interioridade. Esta deixa de ser um impulso a favor da exterioridade para tornar-se um impulso na direção de si, movimento antinatural de interiorização” (cf. op. cit., p. 25).

141 Tal como As duas fontes da moral e da religião mostrará, pela distinção entre as sociedade fechada e as sociedade aberta.

142 Esse texto de $A$ Evolução criadora deixa claro o modo como Bergson entende a ação do princípio vital: "De nosso ponto de vista, a vida aparece globalmente como uma onda imensa que se propaga a partir de um centro e que, na quase totalidade de sua circunferência, se detém e se converte em oscilação no lugar: em um único ponto o obstáculo foi forçado, a impulsão passou livremente” (E.C., p. 266).

143 “E é preciso compará-la [a vida] a um elã, já que não há imagem tomada do mundo físico que possa dela dar mais aproximativamente a idéia. Mas, isso é apenas uma imagem, e é da essência do psíquico o envolvimento de uma pluralidade confusa de termos que se interpenetram” (E.C., p. 258). “ [...] um imenso esforço, tentado pelo pensamento, para obter da matéria alguma coisa que a matéria não quer lhe dar” (M., p. 486), é “a consciência lançada através da matéria” (E.C., 183).

144 "Em suma, somos livres quando nossos atos emanam de nossa personalidade inteira, quando eles exprimem, quando têm com ela essa indefinível semelhança que se encontra, às vezes, entre a obra e o artista” (E., p. 129). 
Assim, somos criadores de nós mesmos e esta é uma experiência direta da criação pela qual Deus é definido, conforme assinalado acima (E.C., p. 249). Como “criadores de nós mesmos”, tomamos parte do princípio. Neste sentido, não há diferença de natureza entre ele e nós, pois não se trata mais aqui de diferenças de natureza ${ }^{145}$, mas da natureza da diferença, e o princípio é ação que se exerce pela diferenciação - das espécies, da personalidade, de tudo (as singularidades).

A filosofia, tal qual Bergson a entende, deve partir da existência para que o Tempo seja imediatamente dado e o Absoluto não seja negado. A consciência liberta do negativo é capaz de um conhecimento tão desinteressado quanto verdadeiro. Ela se descobre participante do Absoluto e assim pode sê-lo em sentido ativo: não só é parte, como participa. Ela se pensa, e pensar o pensamento é fazer a experiência da experiência ${ }^{146}$ - ou seria uma experiência cega, apenas superficialmente vivida. Ela não é, como no instinto, uma “consciência fascinada”, que apreende o Ser "por dentro" sem que disto se dê conta, nem é, como na inteligência, uma "consciência desperta”, mas que manipula o Ser “por fora”: é desperta - consciência de si - e capaz de apreender as coisas "por dentro”, no que elas são, em sua singularidade e em sua diferença. Ao deixar os pseudos problemas oriundos da projeção da prática para a contemplação, a filosofia se revela capaz de "um conhecimento que, sendo desinteressado, não deixa de ser acompanhado pela plenitude afetiva da alegria”" ${ }^{447}$. Ela ganha e ganhamos nós: "nos sentiremos mais felizes e mais fortes” (P.M., p. 116). A alegria é o sentimento que em toda a obra de Bergson acompanha a experiência da duração, enquanto a angústia e sua família (falta, vazio, decepção) acompanham a eternidade sustentada pela tradição, e que tem no Nada o seu fundo secreto e, mesmo, insuspeito. Se, como procuramos mostrar, a eternidade espinosana é o ápice, para Bergson, do pensamento intelectual às voltas com a ilusão do Nada, e a sua crítica a esta noção visa, de acordo com as suas palavras, à concepção espinosista do Ser, então, não é estranho que, ao discorrer sobre o pensamento ou a percepção na experiência da duração ${ }^{148}$, Bergson retome, modificando essencialmente, uma fórmula famosa da filosofia espinosana: a afirmação do conhecimento sub specie aeternitatis, a ela substituindo o sub especie durationis. Assim, finalizamos com um texto que nos mostra a diferença entre ambos, tal como Bergson a vê e evidencia:

145 Sobre essa inversão (da diferença de natureza para a natureza da diferença), conferir o texto de Deleuze "A concepção da diferença em Bergson” in Bergsonismo, pp. 95-125.

${ }^{146}$ Expressão utilizada por Frédéric Worms.

147 Bento Prado Júnior, op. cit., p. 68.

148 Trata-se, nesse sentido, não de nossa percepção habitual, mas da "extensão e vivificação de nossa faculdade de perceber” (PM.., p. 157). 
Com efeito, quanto mais nos habituamos a pensar e a perceber todas as coisas sub specie durationis, tanto mais penetramos na duração real. E quanto mais nela penetramos, tanto mais nos reinserimos na direção do princípio, no entanto transcendente, do qual participamos e cuja eternidade não deve ser uma eternidade de imutabilidade, mas uma eternidade de vida: de que outro modo poderíamos viver e nos mover nela? In ea vivimus et movemur et sumus (P.M., p. 176). 


\section{Capítulo 3 - Espinosa: unidade e eternidade}

A construção da leitura espinosista

Há uma carta de Bergson, de 7 de julho de 1928, endereçada a Vladimir Jankélévitch, na qual, comentando o livro que o seu correspondente acabara de escrever sobre a sua filosofia, ele diz o seguinte: "Eu particularmente anotei a passagem concernente a Espinosa. Creio ter lhe dito que me sinto sempre um pouco em mim mesmo quando releio a Ética, e experimento, a cada vez, uma surpresa, já que a maior parte de minhas teses parecem ser (e são efetivamente, no meu pensamento) o oposto do espinosismo" ${ }^{149}$. Mas o que é o espinosismo? O monismo panteísta? O paralelismo? O puro mecanicismo? O idealismo? A velha metafísica? Então, realmente Bergson se opõe a ele. Mas, se oporia realmente a Espinosa? Será o mesmo opor-se a Espinosa e ao espinosismo?

Numa nota explicativa, inserida na introdução do livro A nervura do real, Marilena Chaui esclarece o uso que faz dos termos espinosismo, espinosista, espinosano/espinosana, demonstrando a necessária distinção entre eles:

Os leitores observarão que, no correr deste livro, empregamos três termos para nos referirmos ao pensamento de Espinosa: espinosismo, espinosista, espinosano/espinosana. Espinosismo e espinosista são empregados para significar: 1) as críticas e as imagens pejorativas relativas à obra de Espinosa; 2) as referências, também pejorativas, que autores fazem a outros para indicar sua suposta filiação ao pensamento de Espinosa, seja do ponto de vista teórico, seja do prático; 3) a caracterização da obra de Espinosa como doutrina. Espinosano/espinosana são empregados para indicar o que consideramos expressão do próprio pensamento do filósofo, suas ideias e seu discurso ${ }^{150}$.

Bergson, evidentemente, não faz a separação acima apresentada, o que nos remete imediatamente tanto à necessidade da distinção, indicada por Chaui, entre a filosofia de Espinosa e o espinosismo, quanto ao fato de a leitura bergsoniana se inserir quase que naturalmente na vertente espinosista. Referimos a uma tradição de leitura e interpretação dos textos espinosanos, e isto não somente pelo uso dos termos - algo banal e ordinário em sua época -, mas por aquilo que ela contém de críticas e mesmo imagens pejorativas de tal filosofia. Pensamos que a separação entre a

149Carta publicada na reedição do livro de JANKELEVITH, Henri Bergson. Paris: PUF, 1959, p. 253.

150 CHAUI, M. A nervura do real: imanência e liberdade em Espinosa. São Paulo: Companhia das Letras, $1999 ;$ p. 21. 
perspectiva propriamente espinosana e a caracterização da doutrina espinosista é importante porque distingue a obra de sua futura interpretação (muitas vezes distorcedora), cristalizada numa certa tradição, revelando-nos possíveis fontes da própria leitura bergsoniana. Faz-se importante, então, entender como e por que surge o espinosismo.

Segundo as análises de Chaui, "A construção do espinosismo”"151 inicia-se com o verbete Spinoza, escrito por Bayle em seu Dicionário histórico e crítico (1702), isto é, com ele “nasce propriamente a tradição interpretativa do espinosismo" ${ }^{\# 2}$. De acordo com Chaui, o conjunto de traços articulados que Bayle oferece inaugura as principais vertentes da interpretação da obra de Espinosa $^{153}$. Ora, a leitura de Bergson certamente não pôde se furtar à influência das "idéias, imagens e sugestões que iriam alimentar, durante os séculos vindouros, as sucessivas leituras da obra e, mais frequentemente, as substituiriam, o verbete sendo mais lido do que Espinosa” ${ }^{154}$. Bergson, de todo modo, não só leu Espinosa, como ministrou cursos sobre a sua obra. O quanto tal leitura foi influenciada pela tradição interpretativa inaugurada por Bayle é algo que podemos apenas apontar ou sugerir, e isto pela maneira como a sua crítica é construída. Ao levantarmos os aspectos que a caracterizam, encontramos muitas semelhanças com toda essa tradição. Se tomarmos a leitura que Bergson fez da obra de Espinosa desde os primeiros cursos ministrados até os textos em que ele é claramente criticado ou é implicitamente um de seus interlocutores, vemos um leque de tendências críticas, as quais são, inclusive, contraditórias entre si, como explicitaremos adiante. A obra de Espinosa gerou de fato leituras e conflitos desse quilate porque, ainda nas palavras de Chaui, suas idéias foram expostas num duplo registro simultâneo: "no do discurso que diz o novo, ao mesmo tempo em que se realiza como contradiscurso e vai demolindo o herdado” ${ }^{155}$. A tentativa de compreensão, ao se pautar pelo "antigo”, corre o risco justamente de considerá-la contraditória. A leitura de Bergson, como de muitos outros filósofos ou comentadores, apresentou a imagem acima descrita devido a algo da própria obra (seu caráter original) e também à tradição de interpretação

151 Título da Parte I do livro Nervura do real: imanência e liberdade em Espinosa.

152 CHAUI, op. cit., p. 281.

153 Bayle "introduz a tendência contínua e tenaz da fortuna crítica do espinosismo, isto é, o uso da biografia de Espinosa tanto como peça de acusação quanto como álibi para salvar-lhe a vida, condenando-lhe a obra. Inaugura as principais vertentes da interpretação da obra de Espinosa, ao oferecer um conjunto de traços articulados que viriam a se desarticular, posteriormente, nas interpretações de seus sucessores: dele vem a imagem do Espinosa cabalista, que Wachter e Leibniz iriam explorar; a do oriental, que, primeiro, Malebranche e Leibniz e, depois, Hegel não cessariam de enfatizar, vindo a ser retomada por intérpretes nossos contemporâneos; a do materialista, que iria receber a boa acolhida dos ilustrados franceses, a repulsa dos idealistas alemães e o interesse de Feuerbach, Marx e Engels, passando aos marxistas, até chegar a nossos dias; a do místico entusiasta, que repugnaria Kant, mas iria apaixonar os românticos; a do herdeiro de Duns Scotus, que será desenvolvida por nossos contemporâneos” (Cf. CHAUI, M., op. cit., p. 281; grifo nosso).

154 CHAUI, op. cit., p. 281.

155 Ibidem, p. 37. 
mencionada. O mesmo poderia valer para os filósofos cuja filiação ao espinosismo, declarada por eles mesmos ou não (os médicos filósofos do século XVIII), mas enfaticamente afirmada por Bergson, faria da obra de Espinosa fonte incontestável da psicofisiologia e do associacionismo contemporâneos, como vimos no primeiro capítulo. De acordo com o próprio Bergson, muitos certamente não leram Espinosa, mas leram outros autores que o haviam lido ${ }^{156}$. Há que se considerar uma atmosfera de "idéias, imagens e sugestões" que, muito provavelmente, neles estava presente pela leitura do verbete ou de autores que o leram, como estava presente, pensamos, não apenas para, mas em Bergson ${ }^{157}$.

O "verbete Spinoza cobre um campo vasto de referências que balizam a acusação de ateísmo” e, no caso da metafísica, dizem respeito à unicidade substancial e ao mecanicismo. Num primeiro momento, Bayle constrói a imagem do "ateu virtuoso" 158 , e revela um certo estranhamento quanto ao fato de se ver, de um lado, um ateu cuja vida seja tão honesta e prestativa e, de outro lado, muitos crédulos que se portam mal. Segundo Marilena Chaui, a pergunta que o autor está fazendo se refere à precipitação do filósofo no ateísmo. Por que ela ocorrera? E a resposta é: "porque exagerou as ideias de Descartes"159. O "cartesianismo mal compreendido é germe do ateísmo”. Bayle introduz uma categoria nova no século XVII, que só conhecia o “ateu prático”, a saber: a de ateu especulativo ${ }^{160}$. Para o autor do Dicionário, Espinosa fora "o primeiro a reduzir o

156 "Todos os historiadores da filosofia mostraram o quanto Espinosa influenciou todas as teorias modernas atuais, diríamos mesmo contemporâneas [...], não que os autores tenham conhecido Espinosa, mas eles conheceram outros autores que tinham se inspirado em Espinosa" (curso sobre a "História das teorias da memória" in Annales II, p. 114). 157 A leitura de Bergson, por um lado, se insere na tradição que surge com o verbete, e, por outro lado, ajuda a manter a "perenidade" da imagem construída de Espinosa, tal como lemos na Parte I do Nervura do real, mais especificamente no tópico "Nasce a tradição": "Na tentativa de diminuir o fascíno que a obra exerce sobre os contemporâneos, Bayle descobre espinosismo em toda parte e em toda época, exorcizando sua originalidade ao fazê-la sincretismo incoerente. Todavia, o efeito devastador pretendido pelo Dictionnaire parece concretizar-se em seu oposto: ao apresentar o espinosismo como doutrina existente em todo tempo e lugar, o verbete constrói a imagem da perenidade de Espinosa, que reaparecerá no adágio hegeliano - 'Ou Espinosa ou nenhuma filosofia' - e no dito de Bergson - 'Todo filósofo possui duas filosofias, a sua e a de Espinosa'. Porém, se lidos em seus respectivos contextos, o adágio de Hegel e o dito bergsoniano não frustram inteiramente a expectativa bayleana. De fato, o primeiro significa que, se toda filosofia deve começar com Espinosa, necessariamente não pode terminar nele, pois todo começo é abstrato e se o absoluto começa como substância, termina como espírito, porque é sujeito; e o segundo, que $o$ espinosismo é a tendência natural da inteligência a fixar-se na imobilidade do Ser, a petrificar-se no utilitarismo instrumental que precisa ser contrariado pela criadora mobilidade do elã vital e da intuição. O verbete Spinosa é devastador porque constrói a imagem do espinosismo com última aparição do eleatismo" (CHAUI, M., op. cit.,; grifo nosso).

158 "Como Bacon, Bayle não admite a possibilidade do ateísmo como teoria; aceita-o como atitude prática e propõe o conceito de 'ateu virtuoso', porque não pode aceitar a figura clássica do 'ateu prático', que, por definição, só poderia ser imoral” (CHAUI, M., op. cit., p. 295).

159 CHAUI, M., op. cit., p. 283; grifo nosso.

160 "Para Bacon, Descartes e Leibniz, o ateu é uma figura aquém da razão, e por isso um ateu especulativo é uma contradição nos termos [...]. Um 'ateu de teoria', como diz o século, é impossível. Para Bayle, no entanto, a existência do sistema espinosista aparece como a finalização do projeto insensato da razão moderna: levado às últimas consequências, o racionalismo só pode ser ateísmo especulativo (CHAUI, M., op. cit., p. 298). 
ateísmo a um sistema”, "transformando-o em doutrina e dando-lhe um método de demonstração matemática”161, e cuja causa estaria no papel conferido à razão por Descartes e pelas igrejas que pretenderam racionalizar a fé, por temor dos efeitos da nova filosofia cartésio-hobbesiana. A contribuição histórica, do ponto de vista metafísico, a esse ateísmo sistemático oriundo do racionalismo cartesiano, foi dada

pelos materialistas, “adoradores de átomos” (Demócrito, Epicuro e Lucrécio) e "adeptos do fatalismo" (os estóicos), e pelos espiritualistas, "adoradores das estrelas" (platônicos, neoplatônicos e peripatéticos, que favoreciam a teologia astral e a astrologia), os que "admitem uma Alma do Mundo" (hindus e persas) ou um 'Espírito do Mundo' (os herméticos, como Fludd, Digges e mesmo Gilbert) ${ }^{162}$

Esse conjunto de elementos ateus, juntamente com os responsáveis pela contribuição no campo da ética e da política, “esparsos e fragmentados”, transformaram-se "em sistema na obra de Espinosa”. Os dogmas afirmados pelo ateísmo são: “identidade entre Deus e universo, eternidade e necessidade da Natureza, inexistência de entes singulares ou de indivíduos distintos da substância divina”. Ou seja, todos vão ao encontro da crítica bergsoniana, ainda que ela nunca se dirigisse ao sistema ateísta, mas apenas ao sistema espinosista. De todo modo, segundo Bayle, o "ateísmo sistemático ou especulativo é a predisposição atéia transformada em teoria matematicamente demonstrada" ${ }^{163}$. Espinosa é, nesse caso, o primeiro e mais significativo exemplar, assim como o é no que concerne à extrapolação da capacidade simbólica da inteligência, o que faz dele, em qualquer das críticas - feitas contra o ateísmo especulativo ou contra a metafísica oriunda do mecanicismo cinematográfico da inteligência -, “a expressão acabada do abismo racionalista, aberto pelo fortalecimento imoderado da razão" ${ }^{164}$. Em Bergson, o exagero das ideias de Descartes gera o paralelismo e a unicidade substancial, que o fundamenta, e tal exagero, não significando incompreensão do cartesianismo, é a radicalização de uma de suas tendências.

O núcleo da crítica de Bayle é a unicidade da substância espinosana (“centro nervoso” da doutrina), cuja consequência é a identidade entre Deus e a Natureza, destruindo o ser divino e desordenando os seres naturais. A crítica à unicidade leva a uma dupla condenação do espinosismo: intelectual e moral. Ora, a crítica de Bergson não se voltava para o suposto ateísmo de Espinosa: isto não estivera no centro de sua preocupação. Mas, certamente, era de seu conhecimento a 
existência e o peso de tal acusação, uma vez que a tradição de leitura do filósofo se fizera, em grande parte, a partir desse prisma, lugar comum no que tange à sua interpretação. O ateísmo seria uma consequência natural do sistema espinosista. Podemos dizer que ele radicalizara a tendência presente em toda a metafísica moderna que, no entender de Bergson, por trabalhar "fora da experiência, sobre puros conceitos, por força havia de se suspender a um conceito de onde se pudesse tudo deduzir e que contivesse tudo. Tal era justamente a idéia que ela se fazia de Deus” (P.M., p. 50). Incompreensível foi o fato de ter chamado de Deus um princípio que nada teria em comum com o que sempre fora designado com essa palavra. Ele seria nada mais que um "Ser cuja essência o condenaria a não levar de modo algum em conta as invocações humanas, como se, abarcando teoricamente todas as coisas, fosse, de fato, cego para nossos sofrimentos e surdo para nossas preces” (P.M., p. 51). Se tal confusão, entre uma ideia explicativa e um princípio agente, foi algo comum na filosofia moderna, ela é a própria doutrina espinosista em sua manifestação conceitual e simbólica. Ao mesmo tempo, a crítica à divindade espinosista também se refere a outro lugar comum da tradição interpretativa do espinosismo: o panteísmo, como veremos logo a seguir.

Apesar de Bergson considerar os problemas oriundos desse princípio explicativo (a divindade espinosista) como algo concernente à filosofia, e não a qualquer querela religiosa, ele sabia o quanto isto inquietara os filósofos que se dedicaram à crítica de Espinosa, bem como entendia que a preocupação maior de Espinosa era com a moral (Cours III, p. 95). A seu ver, a geometrização do sistema arruinaria não só a explicação para a relação entre a alma e o corpo, por exemplo - as preocupações metafísicas -, como a própria possibilidade de uma moral, uma vez que comparando ambos (o moralista e o geômetra), conclui que um "não reforma mais a humanidade, tratando do bem e do mal”, assim como o outro não "modificaria a posição de um corpo determinando as condições de seu equilíbrio” (Cours III, p. 95). E, no caso de Espinosa, eles são o mesmo. Também podemos ver, portanto, uma condenação intelectual e, outra, moral, por motivos distintos dos de Bayle. O reconhecimento de um primeiro princípio não é prova de não-ateísmo, para Bayle, e isto pode ser evidenciado pelas filosofias antigas e pela de Espinosa, na modernidade. Para se distinguir do ateísmo, ela deveria reconhecer que "esse primeiro ser não age por emanação, nem produz o mundo por uma ação imanente, que ele não é determinado por uma necessidade natural, e que ouve nossas preces, podendo mudar o curso das coisas para atendê-las” ${ }^{165}$. Mau moralista e mau metafísico, já que, da unicidade substancial espinosista, segue a negação da individualidade - não há

164 Ibidem, p. 303.

165 Bayle, Dictionnaire historique et critique apud CHAUI, M. op. cit, p. 303. 
condições para a individuação dos seres finitos. De acordo com Bayle, são necessárias - e suficientes - três condições para a individualidade: a pluralidade substancial, a imortalidade da alma e um princpío metafísico de distinção real entre o bem e o mal, sendo que nenhuma delas é preenchida pela filosofia espinosista ${ }^{166}$. Ora, no entender de Bergson, tal como expusemos no capítulo anterior, a moral espinosista não teria qualquer eficácia, e as dificuldades maiores desse sistema consequências da necessidade inerente ao sistema geométrico - girariam justamente em torno do sacrifício da liberdade e da individualidade (existência real da alma individual), a qual deveria ser considerada como necessariamente ligada à memória, resistindo esta inclusive à morte. Tais são também as consequências da crítica que ele empreende ao panteísmo, o qual é explicado, num curso proferido no Licée Henri-IV, em 1888-1889, mesmo momento em que o Ensaio sobre os dados imediatos era preparado, inserindo Espinosa numa tendência heraclitiana. Esta poderia causar estranhamento, se pensarmos que o núcleo da crítica à lógica do sistema espinosista fazia dele o ápice do eleatismo. Mas, também como consideramos anteriormente, todas essas tendências convivem no espinosismo. Vale, portanto, apontar aqui a crítica ao panteísmo, e reunir essas distintas tendências, de modo a ver como elas reproduzem a disparidade do sistema espinosista, aos olhos de Bayle, ainda que a leitura bergsoniana seja feita com outros interesses.

No mencionado curso, Bergson situa o espinosismo entre o sistema materialista e o sistema espiritualista, cujo “intérprete mais autorizado” é Leibniz, uma vez que “entre esses dois sistemas, se coloca um terceiro, esboçado por Heráclito e pelos estóicos e que tomou com Espinosa uma forma precisa e mesmo matemática, o panteísmo” (Cours I, p. 363). O panteísmo se distinguiria do materialismo por não reduzir a existência ao plano físico ou material, e, do espiritualismo, por não aceitar que dois princípios diferentes e opostos possam conviver lado a lado, mesclando-se ou se relacionando em alguma medida ${ }^{167}$. Assim, Bergson define o panteísmo como:

a hipótese, ao mesmo tempo, obscura e profunda de uma substância que seria, ao mesmo tempo, una e dupla, matéria e espírito, necessidade e liberdade, segundo o ponto de vista em que é considerada. É uma mesma força que se traduz, se exprime na natureza inteira, por uma multiplicidade de manifestações. Às vezes, ela se apresenta a nós sob o aspecto de uma força que obedece a uma lei fatal, cujos efeitos são mecanicamente encadeados, e, às vezes, ela toma a forma de espontaneidade, de liberdade, de vida e de reflexão, e esses aspectos são distintos apenas para nosso

166 Chaui, op. cit., p. 312.

167 O espiritualismo, cujo caráter ontológico estaria na afirmação da existência de duas substâncias radicalmente distintas, é um dualismo e, nesta perspectiva, Descartes seria espiritualista. 
espírito que os separa por abstração (Cours I, p. 363).

Essa força é determinada e livre. Isto pode parecer e é contraditório, não constituindo, contudo, um problema para os panteístas, ao contrário. De acordo com Bergson, o "panteísta mais radical”, Hegel, considera que a contradição é o signo da existência. E, em qualquer panteísmo, “desde o de Heráclito ao de Espinosa, encontra-se uma tendência a identificar as contradições, ou seja, a declarar que, na realidade tal como ela existe em si mesma, fora do espírito que a concebe, uma mesma coisa pode ser e não ser, sob a mesma relação e ao mesmo tempo” (Cours I, p. 363). Ora, para Bayle, Espinosa arruína o axioma incontestável segundo o qual opostos não podem ser afirmados para o mesmo sujeito, ao mesmo tempo e na mesma relação, uma vez que termos contraditórios convêm com Deus ${ }^{168}$, isto porque ele é a única substância, enquanto os modos (coisas individuais) nada mais são do que suas maneiras de ser. E dessa maneira, a sua tarefa [de refutador] é concluída, de acordo com Chaui, demonstrando "onde se encontra o absurdo maior do espinosismo: no somatório de dois erros, que formam a monstruosidade filosófica, isto é, um eleatismo heraclitiano" ${ }^{\text {169. }}$

Bergson, por sua vez, considera que Heráclito fora responsável pela dissolução das oposições, aceitando a ideia de uma derivação dos contrários a partir uns dos outros e, por isto, os estoicos, pretendendo desfazer as distinções nítidas, postas por Platão e Aristóteles, voltaram-se para ele, estabelecendo uma conciliação entre espírito e matéria, alma e corpo (CFG, p. 136). Espinosa se filiaria a essa corrente de pensamento, que remete a Heráclito e à assunção de contradições na realidade. Assim, outra consequência do panteísmo, relacionando a doutrina de Espinosa ao pensamento antigo (numa de suas primeiras aparições), decorre do processo pelo qual tudo sai do princípio único, e para o qual retorna: processão e conversão postas pela Escola de Alexandria e, mais especificamente, por Plotino. Por serem parcelas ou fragmentos do espírito que anima o mundo (assim como nossos corpos são partes da matéria universal), nossas almas e suas decisões estão ligadas ao estado e às decisões do espírito divino, de modo que participamos do pensamento divino: somos suas expressões fragmentadas ${ }^{170}$.

168 Cf. A nervura do real, p. 307, no qual lemos ainda que, de acordo com Bayle, na filosofia de Espinosa, "não se pode dizer que Pedro ama ou odeia, mas que Deus modificado em Pedro ama ou odeia, e, portanto, todas as denominações que resultam de todos os pensamentos de todos os homens 'convêm física e propriamente com a substância de Deus'”.

169 CHAUI, M. op. cit., p. 313.

170 Plotino, no "Curso de Filosofia Grega" do Liceu Henri-IV (ano escolar de 1894-1895 - momento de preparação de Matéria e memória), é apresentado como o responsável pela sistematização do pensamento de Platão e pela resolução do dualismo, restabelecendo a unidade do ser, a qual estará no centro da crítica de Bergson à filosofia em 
À crítica ao panteísmo, em geral, podemos acrescentar a tendência que liga o espinosismo à Escola de Eléia, ao imobilismo e aos princípios por ela sustentados, como vimos no segundo capítulo desta tese. A construção espinosista seria a forma suprema da edificação lógica, iniciada pelos eleatas (Parmênides e, sobretudo, Zenão), que orientara a metafísica desde então, impossibilitando a visão da essência do ser como duração criadora - temporalidade não mensurável ou geometrizável. Temos, assim, um quadro geral da doutrina espinosista que espelha, de certo modo, as tendências oriundas da construção bayleana, e de acordo com o qual ela é, para Bergson, ao mesmo tempo: triunfo da lógica e da ontologia parmenidianas; sustentação heraclitiana dos opostos em uma mesma relação e ao mesmo tempo; convicção materialista ou mecanicista da realidade, cuja consequência é tanto a negação de qualquer princípio não material no mundo quanto, por isso mesmo, afirmação de ateísmo; postulação de um determinismo segundo o qual "tudo está dado", o que não se separa de certo fatalismo; identificação de Deus com a natureza (panteísmo); crença em uma Alma do mundo,

geral e à espinosista, em particular. Para Plotino, o princípio supremo não pode ser nem o que pensa, nem o que é pensado, nem o que se pensa a si próprio. O pensamento é um esforço do múltiplo para alcançar o Uno, que não poderia pensar sem se distinguir daquilo que pensa, ou sem se dividir. O Uno ou Princípio é Deus, a unidade perfeita que basta a si mesma. Segundo Bergson, Plotino concebe a liberdade divina “do mesmo modo que Espinosa” irá concebê-la: "é a liberdade que uma definição geomêtrica teria, caso contivesse toda a geometria, não sendo limitada por nenhuma outra e, assim, dependendo apenas de si mesma” (CFG, p. 162; grifos nossos). A leitura do Princípio espinosano, feita a partir da matemática cartesiana, é bastante próxima do Uno plotiniano. Neste caso, o múltiplo ou os seres saem do Uno, sem que ele se divida, por radiação, como os raios de luz saem do sol sem dividi-lo ou a fonte, de onde sai o rio, não se esgota ou flui. Assim, "a geração das coisas por Deus faz-se na eternidade e sem que isso venha a perturbar o repouso de Deus, sem que sua imutabilidade tenha que sofrer com isso. Ponha-se o Uno e será posto também aquilo que decorre de sua essência, o que ele contém eminentemente em sua perfeição. Deus, portanto, vem antes das coisas na ordem da dignidade e na ordem da lógica, mas não na ordem cronológica” (CFG, p. 163). O Uno engendra a Inteligência, por uma radiação, um prolongamento de sua potência, e a Inteligência engendra a alma do mundo, que é um enfraquecimento da Inteligência, traduzindo-se ou expressando-se pelo devir. As almas particulares, por sua vez, são ramificações da Alma universal, coexistem nela e não se confundem nela. Assim como as coisas saem de Deus (processão), há o "retorno", já que aquilo que se refrata se volta em direção ao princípio que o engendrou. Nisso consiste a conversão. E esses dois processos, de geração e de absorção, estão fora do tempo. "O que é engendrado não é posterior àquilo que engendra, mas tudo é dado de uma só vez” (CFG, p. 168; grifo nosso). No caso dos homens, na medida em que as almas se afundam na matéria, mais elas se afastam do seu verdadeiro princípio. O bem verdadeiro consistirá em um retorno a Deus. Movimento este, de volta ou conversão, que tem algumas fases, a saber: a purificação, pela qual a alma adquire virtudes que a retiram do tumulto das paixões; a contemplação, pela qual a alma compreende a beleza das formas, a beleza da alma e a Beleza em si; o êxtase, que é um recolhimento absoluto, pelo qual a alma "vê aparecer Deus ou, antes, toca-o, ela e Deus são uma só e mesma coisa” (CFG, p. 170). O êxtase é superior ao pensamento - que implica a dualidade do pensante e do pensado -, "é uma verdadeira posse de Deus, a volta da alma a Deus, a absorção em Deus” (CFG, p. 170). O movimento de conversão muito provavelmente poderia ser aplicado à concepção de conhecimento presente em Espinosa, na via interpretativa bergsoniana. Nos dois casos - Espinosa e Plotino - haveria uma espécie de síntese das ideias gregas por meio de um certo orientalismo. “Tal é a filosofia alexandrina, síntese de todas as filosofias da Grécia, mas síntese operada à luz de idéias tomadas de empréstimo ao Oriente, que se inspira visivelmente nas teologias judaica e cristã. Na alma do mundo, reconhecemons sem dificuldade a psiqué dos estóicos; na Inteligência, reconhecemos o Deus de Aristóteles e o de Platão; mas o Uno dos alexandrinos, o Uno superior ao pensamento é realmente o Deus inexprimível da teologia judaica” (CFG, p. 171). A influência da teologia judaica faz parte das críticas endereçadas a Espinosa por muitos de seus intérpretes. Ao emanatismo plotiano e ao orientalismo que é sua fonte, a doutrina espinosista se filiaria, sendo mesmo a radicalização de ambos. Dessa concepção do Uno, resultam consequências inaceitáveis para Bergson, tais como a dissolução de nossa personalidade e a perda, por parte da alma, após a morte, de todas as lembranças que ela tinha em vida. Após a 
da qual todas as almas particulares sairiam e à qual retornariam, herdeira de concepções orientais (misticismo e orientalismo). Todas essas tendências dispersas e díspares constituem o espinosismo de modo geral, bem como aparecem em distintos momentos do pensamento de Bergson. Elas, no entender dos críticos, foram levadas ao extremo por Espinosa, sendo ele o responsável pela radicalização e até perversão da tradição filosófica, ou pela sistematização do pensamento dos filósofos anteriores e dos cientistas contemporâneos em sua doutrina - a doutrina espinosista ${ }^{171}$.

Um dos efeitos do verbete Spinoza, ainda segundo Chaui, pode ser visto em Leibniz, para quem, numa imagem que lembra a bayliana, Espinosa defende uma Alma do Mundo, “única e difundida por todas as coisas, de sorte os modos espinosistas não são ativos nem individualidades, mas irreais e fantasmáticos, receptáculos de um sopro externo que, quando o corpo se corrompe com a morte, 'retornam ao oceano do Espírito Universal'”, o que destrói a imortalidade da alma e degrada o gênero humano ${ }^{172}$. Todavia, a imagem construída por Bayle foi tão ampla e potente que atingiu inclusive filósofos que se esforçavam por distinguir seu pensamento do espinosista, tal como ocorrera com o próprio Leibniz, que, ainda em vida, tivera que se defender da acusação de espinosismo, e tal como se deu na "querela do panteísmo", controvérsias que tiveram lugar entre certos filósofos alemães do século XIX e que giravam em torno de acusações de espinosismo. Ela teve início com uma revelação feita por Jacobi, em uma carta escrita a Mendelssohn, de acordo com a qual Lessing, amigo íntimo de Mendelssohn e considerado, como ele, um distinto representante das luzes, teria expressado ao primeiro seu completo acordo com os temas principais da filosofia de Espinosa $^{173}$. Tratava-se, na verdade, de uma polêmica cujo centro era a disputa ou polaridade entre o racionalismo ilustrado e a filosofia da fé, e que veio à tona com a publicação das Cartas de Jacobi a Mendelssohn. Este considerara a revelação pública de Jacobi como uma acusação caluniosa, porque colocaria tal teórico da religião natural, defensor do teísmo e da religião da razão, entre os espinosistas, que nada mais seriam que ateus e blasfemadores. Ou seja, considerá-lo espinosista seria caluniá-lo, principalmente porque ele era “em razão de suas origens filosóficas, um adversário de Espinosa”, o que "estaria aliás conforme à tradição da escola leibnizo-wolfiniana da qual fazia

morte, “a alma volta para o grande todo, perdendo qualquer lembrança do que ela foi anteriormente” (Cours I, p. 364). 171 Segundo Marilena Chaui, “com raras exceções, três atitudes parecem comandar as interpretações da obra: para os adversários, Espinosa perverte a tradição filosófica; para seus defensores, ele a radicaliza; para os historiadores científicos, ele a sistematiza, seja corrigindo e clarificando o que fora pensado antes dele, no caso dos filósofos, seja oferecendo um quadro metafísico rigoroso ao que seus contemporâneos não filósofos tentavam pensar e exprimir. Nos dois primeiros casos surge a figura perfeitamente determinada do 'espinosismo'; no terceiro, a representação clara e distinta da 'doutrina espinosista'” (CHAUI, M., op. cit., p. 37).

172 CHAUI, M., op. cit., p. 314.

173 Para uma leitura mais aprofundada dessa temática, conferir o livro de Sylvain Zac, Spinoza en Allemagne: Mendelssohn, Lessing et Jacobi, ao qual devemos algumas informações que apresentamos aqui - as que não forem 
parte” ${ }^{174}$. De todo modo, Mendelssohn toma o cuidado de não sujar a memória de Espinosa, judeu como ele e, ao mesmo tempo, uma pessoa cuja vida demonstrava seu próprio valor, mesmo sendo um espinosista. E mais: ele defende Espinosa contra Bayle, mostrando que o primeiro tem lugar na filosofia européia, não devendo ser excluído nem como ateu, nem como cabalista. Jacobi, ao contrário, considera que Bayle e Leibniz teriam compreendido melhor que ninguém o sistema de Espinosa, e faz coro com a interpretação desses grandes filosófos, de acordo com a qual o espinosismo é tanto afirmação do ateísmo quanto presença da Cabala, sugerindo ainda que o melhor termo para se referir a ele é “panteísmo”, ainda que alguns prefiram “cosmoteísmo”, porque nele "Deus e a matéria infinita seriam idênticos”"175. Mendelssohn, por sua vez, esforçava-se por distinguir o panteísmo da filosofia das luzes ou do Esclarecimento, o que não o impedia de defender a doutrina de Espinosa contra Jacobi. Isto porque o foco da crítica de Jacobi é a afirmação de que a maior realização do racionalismo era o espinosismo, já que suas demonstrações se realizavam por meio de uma razão constituída por regras restritas, das quais "ela pretende ser a única fonte, renunciando assim à verdadeira liberdade, liberdade de escolha que constitui a própria essência do espírito”176. Contra ela, Jacobi erguia a única luz capaz de iluminar a escuridão: a fé. Essas discussões alemãs ainda reverberavam na época de Bergson e podemos supor que ele certamente tinha ciência delas, ainda que não possamos precisar o quanto. Vimos, no capítulo anterior, que ele ligava diretamente o idealismo alemão à filosofia de Espinosa na tentativa de escapar do criticismo kantiano. Ora, o que estava em jogo na “querela do panteísmo” era justamente uma discussão sobre a abrangência da razão, cujas ambições haviam sido ceifadas por Kant, a partir de uma disputa entre a recusa e a acusação de identificação com a perspectiva espinosista. Isto porque o defensor da fé, Jacobi, punha dois termos para o racionalismo: um caminho que conduzia ao kantismo (a concepção de razão que levava ao abandono da verdade absoluta) e o que conduzia ao espinosismo (absorção no absoluto). Ou seja, a questão se coloca pela polaridade entre espinosismo e criticismo, e isto porque, nas palavras de Chaui: "O deslizamento do panteísmo no entusismo e deste no acosmismo é um dos lugares-comuns que orienta as discussões alemãs da obra espinosana, a qual, transformada em espinosismo, é posta como contraponto obrigatório ao idealismo criticista” ${ }^{177}$. Nas Cartas de Jacobi a Mendelssohn, o espinosismo de Lessing é descrito como resultado da "cisão eu-natureza e da

diretamente referidas ao livro de Marilena Chaui, também bastante esclarecedor sobre esse assunto.

174 Zac, S., op. cit., p. 10-11.

175 Cf. CHAUI, M., op. cit., p. 316.

176ZAC, S.., op. cit., p. 17.

177 CHAUI, M. op. cit., p. 317. 
separação Deus-eu-mundo postas pela filosofia crítica”"178, de sorte que se tratará de buscar a unicidade perdida, ou de reconquistá-la, o que será levado a termo pela "reconciliação romântica”, que exaltará Espinosa por considerar que “nele e com ele, a identidade Deus-Natureza é a reconquista do equilíbrio entre imaginação e entendimento, sentimento e razão, liberdade e necessidade, natureza e cultura, a síntese entre substancialidade e atividade" ${ }^{179}$. No contexto dessa reaparição do espinosismo na Alemanha, entre o final do século XVIII e o início do século XIX, fazse presente outra leitura que ficará como marco de uma determinada interpretação do pensamento de Espinosa: a de Hegel. Para ele, a reconciliação romântica é muito rápida e abstrata, pois o panteísmo de Espinosa não é, como supusera Jacobi, um ateísmo vulgar, uma vez que não se trata de cosmoteísmo, mas de acosmismo, pois nesse sistema não se poderia falar propriamente em mundo como um ente positivo, posto que ele é absorvido no absoluto, que é Deus. Assim, segundo Chaui, ele defende Espinosa da acusação de ateísmo, “feita pelas filosofias do entendimento que concebem facilmente a 'negação de Deus' mas não a do mundo" ${ }^{180}$ - e da concepção emanatista ou cosmogônica de alguns românticos. Tal defesa ocorre num contexto em que o próprio racionalismo do filósofo alemão é acusado, “pelas tendências antiespeculativas que dominam a filosofia alemã [...], de panteísmo, primeiro; a seguir, de ateísmo; e, por fim, como esperável, de espinosismo redivivo” ${ }^{181}$. Ao defender o filósofo holandês, Hegel pretende combater o irracionalismo alemão, mas também distinguir o racionalismo de Espinosa do idealismo absoluto. Assim, defendendo Espinosa da acusação de ateísmo, ele explicita as diferenças entre a sua interpretação e a de Bayle, mas também acaba por não invalidar completamentete a discussão ou a contribuição dada pelo autor do Dicionário, orientalizando o pensamento de Espinosa. Vale a pena nos determos um instante, por mais breve que seja, na interpretação hegeliana, pois ela marcará gerações de leitores da obra espinosana ${ }^{182}$, e porque o “panteísta mais radical”, tal como Bergson o via, ou o viu em determinado

178 Ibidem, p. 317.

179 Ibidem, p. 317.

180 Ibidem, p. 319.

181 Ibidem, p. 318.

182 A sua interpretação foi a tal ponto forte que ela acabou se interpondo entre Espinosa e os leitores contemporâneos. Para Mariana de Gainza, a interpretação hegeliana do espinosismo constitui "o sucesso de uma operação pedagógica maiúscula”, o que a faz perguntar pelos "impensados” que "poderiam ter nascido se, por exemplo, Adorno e MerleauPonty" (dois autores críticos de Espinosa com os quais ela afirma especial afinidade) "houvessem lido sua obra sem a intermediação hegeliana”. Em nosso caso, perguntaríamos, obviamente, pelos “impensados” que teriam lugar na leitura bergsoniana. Esta era uma de nossas inquietações, quando iniciamos nossos estudos (não quanto à Hegel especificamente, e sim quanto às leituras da tradição que influenciaram a crítica de Bergson), mas o desenrolar da pesquisa nos fez pensar que, neste trabalho, ela talvez não fosse mais a mais importante. Voltaremos a isto em nossas considerações finais. Para um maior aprofundamento da leitura hegeliana como um "marco interpretativo condensador e singular, de grande força projetiva”, conferir o capítulo 1, "Hegel ou Espinosa”, da tese de Mariana de Gainza, Espinosa: uma filosofia materialista do infinito positivo, defendida no departamento de filosofia da Universidade de São Paulo, em 2008. Também sobre os dois filósofos, a partir da construção de um entrecruzamento que possibilite 
momento - pondo-o na mesma corrente de filiação que Espinosa -, talvez nos ensine algo sobre a sua própria crítica ao espinosismo.

De acordo com Mariana de Gainza, “se Bayle aportou as imagens com que o espinosismo foi substituído, Hegel - podemos dizer - foi o provedor dos conceitos (muitas vezes compatíveis com aquelas imagens) com que se interpretou estendidamente sua filosofia”183. Para Hegel, o sistema espinosista incorpora ao pensamento europeu a concepção oriental da identidade absoluta na substância Una absolutamente infinita que tudo abarca em si mesma, realizando a unificação entre o ser e o pensamento. Desse modo, se, em Descartes, o ser e o pensamento, o corpo e a alma, ainda eram concebidos como extremos reunidos artificialmente pelo conceito, com Espinosa desaparece a oposição, pois “o Absoluto é pensado pela primeira vez como a real integração do contraditório”. Esta seria a grande contribuição do orientalismo espinosano para a filosofia ocidental, "pois a capacidade de conceber a unidade absoluta da realidade é o começo necessário de todo pensamento verdadeiramente especulativo" ${ }^{184}$. Donde, o famoso adágio hegeliano, tantas vezes repetido pela posteridade: “Ser espinosista é o ponto de partida essencial de toda filosofia”. Mas, as consequências desse orientalismo é que ele significa o começo que, enquanto tal, deve ser superado, ou seja, se a filosofia deve começar com Espinosa não deve permanecer ou terminar nele. Ora, o começo, afirmado pelo absoluto ou pela substância Una, exclui a individualidade do sujeito, o qual, confundindo-se com a substância, deixa de ser uma consciência. Haveria, nessa unicidade substancial, um abandono das determinações finitas. Assim, seria preciso superar a abstração do início e outorgar realidade e independência à alma humana. Mas, enquanto Bayle considerava absurdo que termos contraditórios pudessem convir ao mesmo tempo com Deus, Hegel o criticou por ele não ter levado até o fim a contradição como efetividade. Isto porque ele entende que, no sistema espinosista, o negativo é o oposto do positivo e não pode se conciliar com ele, ou seja, tratase de uma negação abstrata e exterior ${ }^{185}$, de maneira que a substância permanece uma "unidade

tanto o confronto como o encontro, conferir o livro de Pierre Macherey, Hegel ou Spinoza, Paris: Découverte, 1990.

183 GAINZA, M. C. de., Espinosa: uma filosofia materialista do infinito positivo, p. 41. Baseamo-nos, sobretudo, nesse texto nos parágrafos seguintes.

184 Ibidem, p. 28.

185 Curiosamente, Bergson reprova na dialética hegeliana (em qualquer dialética) o movimento feito a partir de conceitos abstratos, que "vai de um contrário a outra à força de imprecisão". Para ele, os conceitos sempre ocorrem aos pares e representam contrários, ou melhor, não há realidade concreta a respeito da qual não se possa ter duas visões opostas, ou que não possa ser subsumida em dois conceitos contrários. "Donde uma tese e uma antítse que procuraria conciliar logicamente, mas em vão, pela razão muito simples de que jamais se fará uma coisa com conceitos, com pontos de vista” (P.M., p. 198). Como é o “panteísmo” a corrente que une Heráclito, Espinosa e Hegel, ou seja, é a aceitação ou a exigência da contradição, podemos nos perguntar não somente pela influência hegeliana na interpretação bergsoniana de Espinosa, como também pela influência espinosana na possível leitura bergsoniana de Hegel, ou pela influência da querela que, na Alemanha, fez com que Hegel fosse acusado de panteísmo e espinosismo, vindo daqui a possibilidade de pensar em uma aproximação de ambos na leitura bergsoniana. Talvez, indo mais longe, 
abstrata morta”, pois os modos não têm potência própria, “faltando-lhes o princípio da singularidade como auto-afirmação, já que lhes falta o jogo da negação da negação pelo qual o absoluto se realiza ou se efetua” ${ }^{\text {}}$. Se falta em Espinosa a concretude que só a negação efetiva pode realizar, a multiplicidade é absorvida na unidade ou não tem qualquer eficácia para a realidade das singularidades, pois, nas palavras do filósofo alemão, "só depois de terem sido levados ao extremo da contradição, os múltiplos tornam-se viventes e ativos um frente ao outro, e conseguem na contradição a negatividade, que é a pulsação imanente do auto-movimento e da vitalidade” ${ }^{187}$. Se não há múltiplos viventes ou ativos, não há singularidade e a substância é “unidade abstrata morta”, o que significa que, consequentemente, falta em Espinosa “a forma infinita, a espiritualidade, a liberdade" ${ }^{188}$. Ao mesmo tempo em que identifica o absoluto espinosista com o orientalismo, Hegel o identifica com o Ser eleata, fazendo do filólosofo holondês o representante moderno de Parmênides. Esta duplicidade - seu eleatismo e seu orientalismo - seria inerente ao seu pensamento, de modo que o filósofo alemão reconhece nele uma dialética rudimentar que corresponderia à primitiva dialética heraclitiana. Mas, a dialética espinosana seria, ao final, rejeição do devir, pois este implica que o nada não permaneça como nada e sim transpasse em seu outro, o que Espinosa não faria porque manteria a exterioridade entre ambos, de sorte a cair na identidade para a qual o ser é só ser e o nada é só nada ${ }^{189}$. Identificando-se com Parmênides, o espinosismo se identifica com o começo da lógica e com a idéia do puro ser como absoluto e única verdade. As consequências disto quanto à temporalidade são bem representadas pela interpretação circular do espinosismo, promovida em grande parte pela leitura hegeliana ${ }^{190}$, de modo a considerá-lo como um saber acabado e fechado sobre si mesmo, e que "expressaria a existência atemporal ou eterna da verdade em sua necessidade" 191 .

Para finalizar este curto histórico da leitura espinosista, fixada numa tradição interpretativa

pudéssemos supor que a quase ausência de referências a Hegel na obra de Bergson (ele é mencionado uma única vez na obra publicada pelo filósofo, justamente no trecho que citamos acima, no qual é colocado ao lado de outros idealistas alemães e de Espinosa como exemplos de filósofos que postularam conceitualmente a 'coisa em si', não escpando da problemática kantiana; cf. P.M., p. 49) se deva a que o seu "espinosismo redivido" não é mais contundente e passível de atenção do que o sistema do próprio holandês, mesmo ele sendo “o panteísta mais radical”.

186 CHAUI, M. op. cit., p. 320.

187 Hegel, Ciencia de la logica, Buenos Aires, Ediciones Solar, 1974, p. 372 apud GAINZA, M. C. de. Espinosa: uma filosofia materialista do infinito positivo, p. 26-7.

188 Hegel, Lecciones sobre la historia de la filosofia III, México, Fondo de Cultura Económica, p. 307, apud GAINZA, M. C. de., ibidem, p. 24.

189 Ibidem, p. 143.

190 Ainda que não lhe seja exclusiva, devendo, ao contrário, a uma tradição já existende de leitura circular. A esse respeito, conferir ainda uma vez o livro A nervura do real, p. 46 e seguintes.

191 Mariana de Gainza, “O tempo das partes. Temporalidade e perspectiva em Espinosa” in Cadernos Espinosanos XXI. Tivemos oportunidade de mencionar esse artigo no capítulo anterior, quando apresentamos a intertrepação circular que Bergson fez da substância espinosana. 
que manteve traços que reconhecemos na abordagem bergsoniana da filosofia de Espinosa, vale citar ainda aquele que seria a derradeira possível referência do filósofo francês, o que nos foi sugerido pelo livro de Pierre-François Moreau, Spinoza et le spinozisme. No último capítulo deste trabalho, Moreau faz alusão às acusações e influências despertadas e provocadas pela obra de Espinosa, constituindo "La réception” do espinosismo ${ }^{192}$, tal como o seu título faz ver. Na França do século XIX, o responsável em grande parte pela caracterização da filosofia espinosana como sinônimo de desprezo pela consciência e pela experiência, uma vez afirmada a "necessidade absoluta” (pelo recurso às matemáticas), e como tendência ao panteísmo em sua versão “acosmista” (anulação do mundo, estando dada a sua absorção em Deus), assimilando-o não ao materialismo, mas a um “desvio místico do cartesianismo”, é Victor Cousin:

\begin{abstract}
Victor Cousin, mestre da escola eclética e, em seguida, da instituição universitária, conduz um combate em duas frentes, contra o sensualismo e o tradicionalismo. Ele se reclamou, inicialmente, de Hegel e de Espinosa. Criticado, então, como panteísta pela direita, ele abandona essas referências embarassantes para se instituir sucessor de Descartes, consagrado como 'primeiro psicólogo francês'; e pode, assim, fundar a metafísica sobre a análise da consciência. Numa tal configuração, Cousin e os seus acusam Espinosa de ter exagerado o cartesianismo, desprezando os ensinamentos da consciência e da experiência, e deixando-se impulsionar pelo demônio das matemáticas até a afirmação da necessidade absoluta. Ele inclinou-se, portanto, em direção ao panteísmo ou, de preferência, a uma de suas duas formas: a que absorve o mundo em Deus e não o inverso ( $a$ lição de Hegel foi ouvida). É, portanto, assimilável não ao materialismo, mas, de preferência, a um tipo de desvio místico do cartesianismo. A escola de Cousin fabrica assim alguns estereótipos que terão lugar por muito tempo na Universidade francesa e nos que se inspiram nela"193.
\end{abstract}

192 No livro de Moreau, Spinoza et le spinozisme, apesar de uma possível inclinação em ver, já em seu título, uma sugestão quanto à diferença entre a filosofia de Espinosa e o que se constituiu como "espinosismo", ao longo da tradição interpretativa da filosofia espinosana, não há efetivamente uma demarcação de diferença entre ambos. O autor revela preocupação em apresentar os temas centrais da obra do filósofo, apontando o núcleo de cada um de seus livros (cap. II), o contexto em que apareceram e algumas polêmicas que suscitaram em sua época, bem como também indica controversas e mutações sofridas pelo espinosismo, como a que constitui o "neo-espinosismo”, no século XVIII - “uma nova versão da herança espinosista que recupera o sentido da teoria da substância única, religando-a aos novos desenvolvimentos das ciências da vida” -, mas não faz uma separação entre a filosofia propriamente espinosana e o espinosismo como interpretação e mesmo distorção posterior de suas teses. Assim, o "espinosismo” ao qual ele se refere, e ao qual aludimos acima, na apresentação do livro citado, não é outra coisa senão a filosofia de Espinosa. No final do livro, lemos que a história da recepção do espinosismo não se privou de qualificá-lo e que tais julgamentos, no entanto, diziam mais sobre os que o faziam do que sobre o próprio sistema, o que leva o autor à conclusão de que, “no final das contas, o adjetivo que convém melhor para qualificar o espinosismo é, sem dúvida, o de 'racionalista'” - um racionalismo absoluto, histórico e militante (Cf. Spinoza et le spinozisme, p. 123-4) - , isto é, Spinoza et le spinozisme são um só e o mesmo na compreensão do autor, ainda que não se trate de “qualquer espinosismo”.

193 Moreau, Pierre-François, Spinoza et le spinozisme, p. 117-8; grifos nossos. 
Seria a leitura bergsoniana derivada dos estereótipos fabricados pela escola de Cousin? Ou estaria mais diretamente ligada à própria interpretação hegeliana, fonte das principais críticas contemporâneas à filosofia de Espinosa, e cuja "lição" fora, de acordo com Moreau, ouvida por Cousin, e, podemos inferir, difundida em meio aos estereótipos de sua leitura e dos que "se inspiraram nela”? Se escapara de Cousin, poderia ter escapado de Hegel ${ }^{194}$ ? Ou estaria vinculada à problemática "querela do panteísmo”? Seria Bayle a sua origem primeira? Ou seria Leibniz, que alimentou e, depois, reproduziu o verbete do Dicionário histórico e crítico de Bayle? Ou teria sido feita por meio de quaisquer intermediários ligados a essas referências maiores e determinantes para a compreensão de certos temas espinosistas numa tendência que, com distintas abordagens, constitui uma tradição de leitura? Mas, talvez o mais importante não seja perguntar pelas fontes da leitura bergsoniana de Espinosa e, sim, por sua importância. Que ela se insere numa tradição originada séculos antes, e que é origem das mais díspares leituras, não há dúvida - pelos temas discutidos nos primeiros capítulos e dos quais sucintamente indicamos aqui algumas referências primárias. Haveria nela algo novo? Onde estaria a sua novidade e pertinência? A isto nos reportaremos em nossas considerações finais. Porém, antes de pôr em relevo a importância da crítica ao espinosismo na obra bergsoniana, tal como a compreendemos, é necessário uma inserção, mesmo que breve, em Espinosa para, com a ajuda de estudiosos que se dedicaram a desmontar a tradição acima apontada, revelar o que a "construção do espinosismo" rejeitara ou ignorara ${ }^{195}$. Para tanto, e tendo em vista o vasto campo de discussão a que a obra espinosana dá ensejo, ater-nos-emos aos temas mais explicitamente apontados por Bergson, ainda que dêem margem a muitos desdobramentos, tais como o que sugerimos pela analogia com a "monstruosidade" desenhada por Bayle. Com o intuito de circunscrever a nossa abordagem, utilizaremos como fio condutor a proposição E II, P7 e, a partir dela, indicaremos outras referências, vislumbrando, tanto quanto possível, contrapor certas leituras espinosanas à crítica bergsoniana, ou fazer com que essas leituras reverberem sobre tal crítica. Quem sabe, então, retirado o invólucro que a ensejou, afastando incontestavelmente os dois filósofos, não poderemos ir ao encontro de proximidades, afinidades ou de férteis diálogos (tão

194 Sobre a influência de Hegel na interpretação do pensamento de Espinosa a partir de um confronto entre ambos, conferir o livro de Pierre Macherey, Hegel ou Spinoza, e também a Parte I da tese de Mariana de Gainza, Espinosa: uma filosofia materialista do infinito positivo.

195 Encontramos em filósofos ou estudiosos contemporâneos leituras que nos marcaram de distintas maneiras na apreciação do texto de Espinosa. Eles guiarão a nossa discussão com a crítica de Bergson, que reconstruímos nos primeiros capítulos desta tese, e cuja origem mapeamos brevemente neste tópico. Obviamente, elas não se fazem pela mesma compreensão ou perseguindo os mesmos anseios, sendo distintas e mesmo discordantes em pontos precisos. Tomando-as conjuntamente para aquilo que nos interessa aqui não pretendemos “uniformizá-las” ou "amalgamá-las” numa versão identificadora, mas reunir esforços contrários ao discurso instituído, e explicitar nossa dívida para com eles. 
férteis quanto o próprio confronto)?

A proposição E II, P7 e a unidade espinosana

De tudo o que foi exposto no tópico anterior, podemos perceber que o núcleo das críticas endereçadas pela tradição filosófica a Espinosa é formado por um suposto dilema de acordo com o qual ou a substância é afirmada, enquanto a inteligibilidade da pluralidade natural é negada, ou a pluralidade da Natureza é afirmada, enquanto a substância única deveria ser negada. Das duas proposições simétricas e opostas, a primeira é a que frequentemente prevalece, e a realidade das coisas singulares é, então, limada à Substância única e absoluta. A isto acrescenta-se o problema da ordine geometrico demonstrata, ou seja, a dificuldade ou impossibilidade (para a tradição) de uma filosofia demonstrada matematicamente, o que faria dos modos finitos não seres reais, mas elementos de uma explicação lógica - de um princípio explicativo (Deus) e não ativo, como afirmado por Bergson. Ambos os problemas (da pluralidade modal e do uso da matemática na filosofia) estiveram presentes, como questionamentos, nas cartas enviadas por um correspondente de Espinosa, Tschirnhaus, e foram elas também (suas dúvidas) responsáveis, em parte, por aquilo que se tornaria, digamos, a querela do paralelismo ${ }^{196}$. A outra parte da responsabilidade por essa interpretação se deve à transposição da noção de expressão da filosofia de Leibniz para a de Espinosa e, consequentemente, à transposição do termo que ele usou em seu próprio sistema, para o de seu contemporâneo $^{197}$, o que aparecera, pela primeira vez (ao que parece), em uma das cartas de Jacobi a Mendelssohn ${ }^{198}$. Tanto num como noutro caso, a proposição E II,P7 da Ética sustenta a interpretação. Por ser ela em seu conjunto (enunciado, demonstração, corolário e escólio) a chave desse problema interpretativo, e porque nela se encontra a articulação entre a ordem do conhecimento e a ordem da realidade, explicitando a ordem causal universal, partiremos dela para responder “às dúvidas de Tschirnhaus” em sua versão bergsoniana, formulada na esteira da tradição.

O enunciado da proposição E II,P7 (que já mencionamos ao nos referirmos ao curso sobre a história das teorias da memória) assegura que: “A ordem e conexão das idéias é a mesma que a ordem e conexão das coisas”. Para demonstrá-la, Espinosa afirma que tal “é patente pelo ax. 4 da

196 A esse respeito, conferir a "Nota complementar $n^{\circ} 6$ - O corolário da proposição II, P7 e os problemas do 'paralelismo'” do livro A nervura do real, pp. 763-9. Sobre as dúvidas quanto à pluralidade da Natureza e ao uso da matemática, conferir o mesmo livro (p. 695 e seguintes).

197 Sobre a noção de expressão e o paralelismo, conferir o apêndice desta tese.

198 Rovere, M., "La tentation du parallélisme: un fantasme géométrique dans l'histoire du spinozisme” in Jaquet, C.; Sevérac, P.; Suhamy, A.(orgs). La théorie spinoziste des rapports corps/esprit et ses usages actuels. Paris: Hermann Éditeurs, 2009; p. 49. 
parte I. Pois a idéia de qualquer causado depende do conhecimento da causa de que ele é efeito” ${ }^{199}$. Para entender o que a demonstração significa, é necessário o recurso ao axioma mencionado, no qual lemos que "O conhecimento do efeito depende do conhecimento da causa e o envolve". Ora, o filósofo não demonstra a proposição remetendo-a ao axioma segundo o qual "a idéia verdadeira deve convir com o seu ideado" (ax.6 da parte I), o que seríamos levados a supor pela leitura da proposição. Assim, a demonstração faz ver que o que está em questão primeiramente aqui não é a conveniência entre idéia e ideado (idéias e coisas, neste caso) - é isto também, por haver uma relação entre idéias e coisas, mas não é isto primordialmente. $\mathrm{O}$ axioma citado envia o leitor à relação entre causa e efeito, a qual pode acontecer somente entre modos de um mesmo atributo ${ }^{200}$, e faz ver que o conhecimento de qualquer causado - sejam idéias, sejam coisas - envolve o conhecimento da causa e isto em cada atributo (Pensamento ou Extensão, por exemplo) -, de maneira que se apresenta a independência entre os atributos (posta na parte I) e, concomitantemente, a ordem causal universal. Havendo independência entre os atributos, consequentemente há autonomia entre eles: cada um contém em si e por si aquilo que constitui sua essência, potência e existência. Como não há dependência entre os distintos atributos, sendo todos independentes e autônomos, há uma igualdade entre todos, sem eminência ou primazia de um em relação ao outro. Há igualdade também entre os atributos no que se refere à sua ordem e conexão, que é a mesma para os distintos atributos, ou seja, o fato de serem independentes e autônomos não significa dispersão ou ausência de coesão. Como a demonstração não se baseia na relação entre idéia e ideado, e sim na de causa e efeito, e como a proposição afirma que a ordem e conexão das idéias é a mesma que a ordem e conexão das coisas e não que há uma correspondência entre elas -, o que se evidencia aqui é que tal proposição é prioritariamente metafísica, e que ela apresenta a causalidade própria à substância (causa modos distintos em diferentes atributos numa mesma ordem e conexão). A causalidade é a maneira como age a substância, a qual é causa eficiente absoluta e imanente, ou seja, é causa de si (causa sui) e de tudo o que é em outro (porque é nela), os modos finitos ou infinitos. Ela causa, numa mesma ordem e conexão, uma vez que os distintos modos não possuem a mesma causa atributiva. Como eles envolvem os conceitos de seus respectivos atributos, a ordem e conexão das coisas não causa idéias, assim como a ordem e conexão das idéias não causa coisas.

Para explicar "en détail” essa demonstração e, posteriormente, o corolário da mencionada

199 ESPINOSA, B. Etica. Tradução feita pelo Grupo de Estudos do Século XVII da USP .

200 Nas proposições anteriores, Espinosa demonstrara, dentre outras coisas, que a extensão e o pensamento são atributos de Deus (dois dos infinitos atributos Dele) e que os modos de cada atributo têm Deus como causa apenas enquanto considerado sob o atributo de que são modos, e não sob outro atributo, o que significa que nem idéias causam corpos, nem vice-versa, porque são modos de atributos distintos. 
proposição, Deleuze aponta que o axioma nos reenvia ao princípio aristotélico segundo o qual “conhecer é conhecer pela causa”, mas declara que a perspectiva espinosana não implica apenas esse axioma, uma vez que, como afirmado por Espinosa no Tratado da Reforma da Inteligência, os antigos não conceberam a alma como algo que age de acordo com leis determinadas, como um autômato espiritual. "'Autômato espiritual' significa, primeiramente, que uma idéia, sendo um modo do pensamento, não encontra sua causa (eficiente e formal) senão no atributo pensamento. Do mesmo modo, um objeto, qualquer que ele seja, só encontra sua causa eficiente e formal no atributo do qual é modo e cujo conceito ele envolve”201. Naquilo que tange a esta tese, a diferenciação entre Aristóteles e Espinosa é importante porque nos ajuda a contestar a crítica bergsoniana de que o espinosismo seria “o aristotelismo com vestes modernas”. Não apenas o axioma citado, mas todo o início da parte II se ocupa com uma dupla exclusão que separa, de acordo com o nosso intérprete, Espinosa da tradição antiga: a exclusão de qualquer causalidade eficiente e formal entre idéias e coisas, e também entre coisas e idéias. Porém, fora isto que levara Bergson a considerar, como vimos no capítulo I, que a correspondência era a solução moderna para o problema da relação entre corpo e alma, uma vez posta a separação entre ambos, encerrando qualquer espécie de intercomunicação, como os antigos supunham. Dessa maneira, precisamos interrogar tal "solução", questionando se a autonomia causal dos atributos e a relação entre seus respectivos modos é sinônimo de correspondência. Ou seja, é esta última que define a relação espinosana? O que sustentamos aqui é que além de não haver causalidade entre modos de atributos distintos, não há também transposição de um suposto paralelismo aristotélico para a relação mente/corpo, porque simplesmente não há paralelismo. Se não há paralelismo, a relação entre mente e corpo não pode ser a de correspondência, ou melhor, não pode sê-lo exclusivamente. O que o conjunto da proposição E II,P7 mostra é que a causalidade garante a autonomia sem identificar correspondência e relação. Se se pode falar em correspondência entre idéia e ideado, não é ela que define a relação - ela não é primeira, nem última ${ }^{202}$, o que retomaremos logo a seguir, na continuidade de nossa exposição

201 Deleuze, G. Spinoza et le problème de l'expression, p. 101.

202 De acordo com Chaui, “a correspondência é efeito da atividade causante dos atributos” e a dificuldade de pensar a relação entre os modos finitos que ela [a atividade dos atributos] dá ensejo está no fato de que se trata de uma novidade na maneira de pensar a relação entre corpo e mente. Já para Deleuze, a correspondência é de onde se parte para compreender a relação entre os modos dos distintos atributos, mas não é a última palavra a esse respeito, uma vez que ela significa apenas "identidade de ordem", quando há ainda uma "identidade de conexão" e uma "identidade de ser ou ontológica", sendo esta última a que se refere à imanência, fundamentando, consequentemente, a conexão e a correspondência. Essas identidades formam, para Deleuze, três princípios ou fórmulas do paralelismo, e isto gerou a polêmica quanto ao uso do termo por parte desse estudioso de Espinosa. Apesar de Deleuze não identificar correspondência e relação, o que nos auxilia na discussão da crítica bergsoniana, deixaremos a sua abordagem do paralelismo para o apêndice desta tese, tomando, aqui, apenas as suas considerações que não implicam a mencionada "polêmica". E continuaremos nos guiando também pela leitura de Chaui. 
sobre a proposição sete da parte II da Ética.

O corolário de E II, P7 se liga à demonstração, reconhecendo a igualdade de potências de Deus: "Donde segue que a potência de pensar de Deus é igual a sua potência atual de agir. Isto é, o que quer que siga formalmente da natureza infinita de Deus segue objetivamente em Deus da idéia de Deus, com a mesma ordem e a mesma conexão”. Há uma igualdade entre potência de pensar e potência de agir, que podemos ler da seguinte maneira: "pensar é ação”, ou seja, o que acontece no atributo pensamento, sua capacidade de conhecimento e produção de idéias (seus modos) é ação. Assim, a potência de pensar de Deus é igual a sua potência atual de agir, pois Deus não pode pensar, conhecer ou compreender sem agir ou sem uma produção múltipla de idéias no atributo pensamento. Ora, Deus produz como se compreende e tudo o que produz "cai" necessariamente sob o intelecto divino (E I, P16). Deus não se compreende a si e à sua essência sem compreender tudo o que dela decorre. As idéias decorrem da idéia de Deus assim como os modos seguem ou decorrem de seus respectivos atributos. Também podemos ler a igualdade entre a potência de pensar de Deus e a sua potência atual de agir como sendo uma igualdade de ação entre todos os atributos divinos, os quais, como a proposição já apontara, operam com a mesma ordem e conexão - há uma mesma atividade causal e simultânea em todos eles. Nesse sentido, o final do corolário afirma que aquilo que "segue formalmente da natureza infinita de Deus segue objetivamente da idéia de Deus, com a mesma ordem e a mesma conexão”. A toda e qualquer ação em cada atributo, cujo conjunto constitui a natureza formal infinita de Deus, há uma idéia, cujo conjunto constitui o ser objetivo de Deus, que também é ação no atributo pensamento. Deus age e se pensa concomitantemente, ou seja, não pensa antes de agir, não age sem que, de sua ação, se dê um pensamento em seu intelecto infinito. Não há separação entre agir e pensar em Deus. Deus não pensa antes de agir significa que não pensa possíveis que poderão passar à existência. Assim, não há idéias na mente de Deus esperando para se tornarem reais, e também não há possíveis lógicos, “reais pelo fato de serem possíveis” (na concepção do matemático que Bergson utiliza no curso sobre Espinosa), o que faria do mundo um conjunto de possibilidades dadas no absoluto (fórmulas ou teoremas desdobráveis da sua essência), ainda que não realizadas no mundo ou não conhecidas por nós - o “Tudo está dado”, não por ter sido antes projetado, mas porque a mecânica do sistema assim o permite (de modo que uma inteligência sobrehumana poderia calcular ou ligar todos os elementos, inferindo os acontecimentos futuros e as idéias que os explicam). Da mesma maneira, Deus não tem uma capacidade de ação maior do que a que existe, podendo criar diferentemente as coisas, se outra fosse a sua vontade. Em Deus, ser, agir e pensar são uma só e a mesma coisa. Existindo, Deus age. Agindo, pensa, e o faz em ação (atividade do pensamento) e com a ação de todos os atributos. Nada há não compreendido por ele e que, sendo 
pensado ou compreendido, não seja. Que tudo siga formal e objetivamente de Deus significa que Ele é uma unidade múltipla, porque não se separa de seus efeitos, que são múltiplos, e os unifica, na mesma ordem e conexão, em um único ser. Por isso, não há separação entre idéias e coisas, ainda que não haja relação causal entre elas, uma vez que a causalidade ocorre no atributo ao qual pertencem e cujo conceito envolvem. Trata-se de uma mesma causalidade quando reportada a Deus, causalidade múltipla, em distintos atributos, e infinita, em uma infinidade de atributos e modos que os constituem. Ora, vemos aqui que há uma única e mesma potência causante, assim como há uma causalidade atual e necessária ${ }^{203}$ de coisas e idéias na mesma ordem e conexão. Ou seja, a unidade da potência causante significa (e assegura) que o que segue formalmente da natureza infinita de Deus (as coisas) segue objetivamente da idéia de Deus (as idéias) na mesma ordem e conexão - Deus causa idéias e modos na mesma ordem e conexão porque a potência causante é única. O corolário apresenta a ordem única universal, afirmando a sua inteligibilidade, pois o atributo pensamento produz as idéias de todos os seres formais dos demais atributos, na mesma ordem e conexão. Ele age, produzindo idéias, as quais não existem menos que os corpos, ou seja, a potência de existir não se confunde com o atributo extensão. Idéias e coisas são, portanto, fruto da atividade simultânea dos atributos extensão e pensamento. Como eles produzem na mesma ordem e com igual necessidade, a correspondência entre os modos (conveniência entre a idéia e o ideado) é decorrência da atividade causante da substância, cuja potência é a mesma em seus distintos atributos ${ }^{204}$.

203 Na Parte I, de acordo com Chaui, "Espinosa demonstra que todas as coisas seguem necessariamente da essência e potência de Deus, que essa essência e potência são idênticas e que as coisas não poderiam ser produzidas por Deus doutra maneira nem noutra ordem. Qual é a maneira? A causalidade livre eficiente imanente. Qual é a ordem? A sequência necessária em que da natureza absoluta dos atributos seguem modos infinitos imediatos e da natureza modificada dos atributos seguem o modo infinito mediato e os modos finitos” (Cf. A nervura do real, p. 594).

204 Deleuze considera que igualdade das potências significa que o absoluto teria duas metades. "Deus, ou seja, o absolutamente infinito, possui duas potências iguais: potência de existir e de agir, potência de pensar e de conhecer” (Deleuze, G. Spinoza et le problème de l'expression, p. 103). Ele possui as duas potências "em si e por si, envolvendoas em sua unidade radical”. “As duas potências não têm, portanto, nada de relativo: são as metades do absoluto, as dimensões do absoluto, as potências do absoluto” (ibidem, p. 104; grifo nosso). Isto permitiria falar em um certo privilégio da potência de pensar, o que, para ele, significaria um “aparente” privilégio do atributo pensamento. A distinção entre a igualdade de potências e a igualdade dos atributos é essencial, para Deleuze. Mas se de um lado, todos os atributos são iguais (mesma potência de existir e agir), de outro, essa potência de existir é apenas uma metade do absoluto, sendo a outra uma potência de pensar, que é igual a ela, e em relação à qual o atributo pensamento gozaria de privilégios, condicionando sozinho uma potência igual à que todos os atributos condicionam. Não se trataria de uma contradição, mas de um "fato último”, o qual não se refere à nossa constituição ou ao limite de nosso conhecimento, mas que se reportaria à constituição divina ou ao desenvolvimento do absoluto. Nenhum atributo preenche a potência de existir, enquanto a potência de pensar ou conhecer é completamente preenchida pelo atributo pensamento (ibidem, p. 107). Seria contraditório, para Deleuze, se Espinosa pusesse a igualdade dos atributos e, depois, sob o mesmo ponto de vista, desse ao atributo pensamento poderes e funções contrárias a essa igualdade. Não é isso que ele faz, pois, na sua interpretação, é a igualdade de potências que confere ao atributo pensamento poderes particulares, em um domínio que não é o da igualdade dos atributos. Há, assim, uma diferença entre esta leitura deleuzeana, a qual compreende que se trata de duas potências iguais (donde o privilégio de uma sobre a outra) e aquela que considera a igualdade das potências como afirmação de uma única potência causante (o que exclui 
Se tal proposição é prioritariamente metafísica e apresenta uma identificação da ordem e conexão (é a mesma) das idéias e das coisas na causalidade necessária da substância, e se partimos da “desconstrução do espinosismo", porque este faz do par identidade/causalidade o núcleo da crítica da indiferença nesse sistema (considerando que, no tipo de causalidade espinosista, o efeito acabaria por se identificar com a causa como decorrência da unidade que define um monismo, um panteísmo, um acosmismo ou um emanatismo, doutrinas nas quais não há diferença efetiva), temos de nos perguntar o que significa essa identificação e se a diferença é realmente excluída nessa filosofia, que afirma a unidade substancial. Enquanto o corolário da proprosição E II, P7 apresenta $a$ unidade de potência da substância, que gera uma mesma atividade simultânea nos atributos de Deus, cabe ao escólio a unidade dos atributos, e será ele que nos permitirá repor o que expusemos anteriormente, sobre a mencionada proposição e seus desdobramentos, numa espécie de contraprova crítica da tradição.

O escólio tem início com a afirmação da unidade da substância, tal como lemos:
Aqui, antes de prosseguir, cumpre-nos trazer à memória o que mostramos acima: o que quer que possa ser percebido pelo intelecto infinito como constituindo a essência da substância pertence apenas à substância única e, por conseguinte, a substância pensante e a substância extensa são uma só e a mesma substância, compreendida ora sob este, ora sob aquele atributo.

Que a substância seja única (substância pensante e substância extensa são uma só e a mesma substância) não significa que não haja distinção real entre seus atributos. É isto que Deleuze demonstra no início de seu livro Spinoza et le problème de l'expression, separando distinção real de distinção numérica, e mostrando a diferença entre o que Descartes e Espinosa entendem por distinção real. Enquanto Descartes considera que há distinção real entre duas substâncias de atributos diferentes ou entre substâncias de mesmo atributo, existindo, portanto, distinções numéricas que são ao mesmo tempo reais ou substanciais (“distinção que é acompanhada de uma divisão das coisas, de uma distinção numérica que lhe corresponde”), para Espinosa a distinção real não será nunca numérica, o que significa que haverá uma única substância qualitativamente diferenciada. Em torno desta questão é que se articula, para Deleuze, o início da Ética, no qual é demonstrado que pode

qualquer privilégio). Digamos que uma põe em relevo os elementos da operação, enquanto a outra evidencia a própria operação. No apêndice, apresentamos a razão pela qual discordamos da leitura que considera que o "paralelismo" afirmado por Deleuze, no livro sobre Espinosa, iria na mesma direção do que Bergson criticou. Não haveria, assim, uma influência da crítica tradicional na leitura deleuzeana de Espinosa, ao contrário - é feita contra a tradição. Mas, haveria uma influência da filosofia de Bergson na sua compreensão da filosofia espinosana? Ou seja, a leitura que Deleuze faz das "metades do absoluto" poderia ser uma influência do Bergsonismo? Não cabe aqui o tratamento dessa questão, embora consideramos que seria interessante um estudo sobre este tema. 
haver apenas uma única substância, tal como o escólio rememora. Quando consideramos várias substâncias de mesmo atributo, o erro consiste no fato de que elas deveriam se distinguir pelos modos, o que é absurdo (demonstração pelo absurdo), visto que a substância, por natureza, é anterior aos modos e não os implica. E, quando colocamos tantas substâncias quantos atributos diferentes há, fazemos da distinção real uma distinção numérica. Ao final da parte dedicada a explicar esse tema, essencial na filosofia de Espinosa, Deleuze conclui afirmando que: "Há uma substância por atributo do ponto de vista da qualidade, mas uma só substância por todos os atributos do ponto de vista da quantidade”205. Esta multiplicidade puramente qualitativa é justificada pelo novo estatuto da distinção real e quer dizer que "as substâncias qualificadas se distinguem qualitativamente, não quantitativamente. Ou, melhor ainda, elas se distinguem 'formalmente', 'quiditativamente', não 'ontologicamente'”206 . Que a distinção real não seja numérica, e não possa sêlo, é um dos motivos principais da Ética, para Deleuze. Com essa demonstração, vemos que a unidade substancial não é a negação da diferença, mas a sua plena afirmação. Ou, ainda nas palavras do comentador: "Dissociada de toda distinção numérica, a distinção real é dirigida ao absoluto, tornando-se capaz de exprimir a diferença no ser ${ }^{207}$. Vemos também a dissolução da maneira tradicional de pensar a diferença e o par unidade/multiplicidade. Isto, porém, quanto à unidade da substância e a multiplicidade de seus atributos. Resta perguntar pela multiplicidade dos modos. Ou ainda, pela união dos modos de distintos atributos.

Na sequência do escólio de E II, P7, lemos que:

Assim também um modo da extensão e a idéia desse modo são uma só e a mesma coisa, expressa todavia de duas maneiras, o que parecem ter visto certos Hebreus, como por entre a névoa, ao sustentarem que Deus, o intelecto de Deus e as coisas por ele inteligidas são um só e o mesmo. Por exemplo, um círculo existente na natureza e a idéia do círculo existente, que também está em Deus, são uma só e a mesma coisa, que é explicada por atributos diversos (E II, P7esc.).

Ora, Deus se expressa em seus atributos, sendo que cada um se exprime em infinitas coisas em infinitos modos. Isto não significa que um modo exprima outro ou que cada coisa particular deva exprimir outras, exprimindo-se de infinitos modos (espelhamento que subjaz à crítica do paralelismo). Assim, não pode haver uma tradução de um original (reprodução em outra língua), nem uma reciprocidade de duas línguas que exprimiriam um mesmo original, pela correspondência

205 Deleuze, G. Spinoza et le problème de l'expression, p. 30.

206 Ibidem, p. 31. 
de seus termos. No primeiro caso, colocaríamos um atributo como original, fazendo do outro uma réplica. No segundo, colocaríamos o original fora das línguas que o exprimem (não é uma, nem outra), caindo em uma espécie de exterioridade que, de nenhum modo, condiz com a imanência. E mais: os modos não são “termos” de uma língua, o que os faria coisas “dadas e acabadas”, estáticas e isoladas. Como um modo exprime seu atributo, por ser de mesma natureza que ele (não há expressão entre coisas de natureza distinta, ou seja, a expressão é uma relação entre homogêneos), exprimir é “uma ação causal imanente de um princípio único internamente diferenciado” ${ }^{208}$. A expressão de um modo da extensão e da idéia desse modo é “de duas maneiras”, porque cada um expressa seu próprio atributo (Extensão ou Pensamento), mas tanto um quanto o outro "são uma só e mesma coisa" porque não são substâncias distintas e porque constituem uma unidade (um modo da extensão e a idéia desse modo). Assim, um corpo e a idéia desse corpo (a mente) são “uma mesma coisa”, ou seja, uma unidade também causante, também simultânea, e também diferenciada. E porque os atributos constituem a essência e a potência de uma única substância, e são eles as causas diferenciadas de todos os seres quanto à essência e à existência, produzindo os modos como realidades singulares, estes existem em Deus e são concebidos por Deus. Sabemos que "tudo o que é, é em Deus, e nada sem Deus pode ser nem ser concebido” (E I, P15), que de tudo o que existe há uma idéia em Deus, ou que "Deus é causa eficiente de todas as coisas que podem cair sob o intelecto infinito" (E I, P16cor.), como a parte I da Ética demonstrara, de sorte que, "Deus, o intelecto de Deus e as coisas por ele inteligidas são um só e o mesmo”. Da unidade substancial (diferenciada) e de sua simultaneidade causal (complexa), entendemos que

quer concebamos a natureza sob o atributo Extensão, quer sob o atributo Pensamento, quer sob outro qualquer, encontraremos um só e a mesma ordem, ou seja, uma só e a mesma conexão de causas, isto é, as mesmas coisas seguirem umas das outras (E II, P7esc.).

A afirmação da ordem como conexão de causas é fundamental porque mostra a maneira como a produção substancial ocorre e como deve ser conhecida, explicando o que significa "as mesmas coisas seguirem umas das outras”. Ora, a ordem é conexão de causas em todos os atributos, fazendo com que as mesmas coisas sigam umas das outras em cada atributo, ou seja, produzindo $a$ Natureza em sua inteireza. Ela é também, portanto, o guia para a correta conexão de idéias, uma vez que a ordem e conexão de idéias no Pensamento é a mesma que a ordem e conexão das coisas na 
Extensão. Há, consequentemente, uma articulação entre a nossa ordem de conhecer e a ordem na Natureza. A mesma ordem é natural e necessária, sem que coisas e idéias sejam idênticas, porque idênticas são a ordem e conexão delas, o que é totalmente distinto de dizer que umas (as idéias) são cópias de outras (as coisas), uma vez que identidade de conexão não anula a heterogeneidade dos elementos e seus sistemas de referência - são essencialmente distintos (a essência de um corpo, por exemplo, é uma certa proporção de movimento e repouso, os quais concernem apenas ao atributo extensão, obviamente). A proposição E II, P7 não afirma, portanto, que o modo de existência das coisas seja o mesmo que das idéias, e sim que a conexão das causas, que em cada atributo tem a disposição própria deste mesmo atributo, é a mesma. Conexão que não é em cadeia ou sequencial, nem ligação externa de elementos isolados. Mas, que se realiza segundo uma ordem necessária, de maneira que podemos conhecer as coisas adequadamente, ou seja, conhecê-las na ordem que lhes é devida. Isto não significa conhecer uma pela outra (a idéia pela coisa ou vice-versa), mas conhecê-las de acordo com a conexão de causas da qual são partes efetivas (não isoladas ou isoláveis). Conhecer na devida ordem ${ }^{209}$ é conhecer a ordem natural, as leis que engendram as coisas e, consequentemente, é conhecer sua gênese. É retirar, portanto, qualquer mistério do mundo, da existência ou do nosso conhecimento (mistério que se sustenta pela insondável “vontade de Deus” ou "asilo da ignorância”, como afirmado no apêndice da parte I) ${ }^{210}$. Nas palavras de Chaui: "Porque é conexão causal auto-produzida e auto-regulada, a ordem não é limite, mas, pelo contrário, a via de acesso à infinitude da Natureza como potência infinita de engendramento de todos os seres e de suas

209 No Tratado da Reforma da Inteligência, lemos que “o verdadeiro método é o caminho pelo qual a própria verdade, ou a essência objetiva das coisas, ou as idéias (todas estas palavras significam a mesma coisa) são procuradas na devida ordem” (T.R.I., p. 22). Neste contexto, o método mostra que "a mente deve ser dirigida segundo a norma da idéia verdadeira dada” (ibidem, p. 23), qualquer que ela seja. Na Ética, a ordem mostra que a idéia verdadeira da qual partimos é a do Ser Perfeitíssimo. De qualquer maneira, tanto num quanto noutro caso, o interesse do Método está mais na direção da mente a partir da idéia verdadeira. É uma cura (emendatio), num caso, e uma ética, noutro caso, a qual é estabelecida pela liberdade de ação e pensamento, sendo esta, obviamente, o inverso da servidão em que caímos sob o domínio das idéias inadequadas.

210 Assim, no T.T.-P., ao buscar a autoria e autenticidade dos livros sagrados, bem como as mudanças por eles sofridas ao longo do tempo, Espinosa procura, pelo método cujas regras ele expõe no capítulo 7, “a ordem e encadeamento dos textos”, buscando o sentido dos mesmos, e não a sua verdade. "Que conclusões a ordem propicia? Negar que haja mistérios, segredos e enigmas nos textos, e atribuir à superstição de uns e à malícia de outros a transformação em mistério especulativo daquilo que é obscuridade gramatical, léxica ou literária” (Chaui, op. cit., p. 569). A ordem permite separar o domínio da filosofia (saber) do da teologia (não saber), bem como o que concerne à fè (obediência e piedade), e que pode fundamentar uma moral ou uma vida religiosa, do que é interesse teológico-político. A ordem distingue ordens e é, portanto, um instrumento contra-ideológico. Ora, a distinção dos domínios de conhecimento tão enfaticamente posta por Bergson (entre ciência e filosofia), é também, sob nossa perspectiva, uma prática contraideológica, revelando, senão os interesses, ao menos os equívocos ocultos ou dissimulados em um pretenso saber que, no fundo, é não saber porque não sabe o que sustenta seu próprio discurso. Os possíveis desdobramentos dessa prática contra-ideológica poderiam ser buscados nos interesses ocultos sob a suposta neutralidade da ciência nos momentos, por exemplo, em que a psicologia se apóia em tais postulados dissimulados, ainda que de modo "inconsciente", dando vazão a concepções determinadas (algumas das quais foram assunto de nosso primeiro capítulo) e determinantes. 
relações necessárias. A substância absolutamente infinita une e diferencia infinitas ordens de existência em determinações que são as leis da Natureza, e as coisas singulares são o próprio ser infinito quatenus exprimem de maneira certa e determinada a substância absolutamente infinita"211 . A ordem e conexão de causas nos atributos produz singularidades que são potências causais, ou seja, maneiras de ser (ativas ou passivas) e não simples efeitos ou acidentes do Ser. Também é preciso considerar que a ordem das idéias na mente e das afecções no corpo é a mesma, na adequação ou na inadequação, isto é, quando somos causa adequada (suis juris), ou quando somos causa inadequada (alterius juris) de nossas ações e pensamentos. Somos ativos de corpo e alma, passivos de corpo e alma. "Em outras palavras, a ordem reflexiva é a mesma que a ordem vivida"212.

No texto do escólio, podemos verificar também que a relação entre idéias no atributo Pensamento, pela qual podemos conhecer adequadamente, não é uma cadeia estéril de elementos isolados, mas uma experiência de pensamento, que se realiza pela percepção ${ }^{213}$ de um ser formal por outro modo de pensar, e que é dinâmica como é dinâmico e ativo o atributo Pensamento (sabemos que todos o são). A dinamicidade causal de todos os atributos (potência de agir), ocorrendo na mesma ordem, faz com que a ordem inteira da natureza possa ser explicada por qualquer um deles, ou tenha de ser explicada assim, pois tanto as coisas quanto as suas idéias devem ser explicadas por sua causa próxima e não pela correpondência entre elas. Dessa maneira, lemos no escólio que:

E por isso quando eu disse que Deus é causa de uma idéia, da de círculo, por exemplo, apenas enquanto é coisa pensante, e do círculo apenas enquanto é coisa extensa, não foi senão porque o ser formal da idéia de círculo só pode ser percebido por outro modo de pensar, como causa próxima, e este, por sua vez, por outro, e assim ao infinito, de tal maneira que, enquanto as coisas são consideradas como modos de pensar, devemos explicar a ordem da natureza inteira, ou seja, a conexão das causas, pelo só atributo Pensamento, e enquanto são consideradas como modos da Extensão, também a ordem inteira da natureza deve ser explicada pelo só atributo Extensão (E II, P7esc).

Assim como falamos de uma experiência de pensamento, a partir do atributo Pensamento, também é preciso apontar o que entendemos por experiência corpórea, a partir da dinamicidade do atributo Extensão, e por que ela também não pode ser considerada uma relação externa e estéril de elementos isolados, mecanicamente compostos. Ora, sabemos que os corpos são definidos por certa ratio de movimento e repouso, o que significa que, para persistirem no existir (e todas as coisas se

211 Chaui, op. cit., p. 597.

212 Ibidem, p. 598.

213Ainda que Espinosa prefira o termo “conceber” a "perceber” porque o primeiro termo aponta melhor (ou com 
definem por esse esforço/conatus), precisam manter tal proporção e, para tanto, é necessário uma relação interna entre seus constituintes - intra partes, e não extra partes, a qual faria do corpo um composto (elementos reunidos por uma força externa), e não uma singularidade. Esta é definida pela finitude (condição de modo) e é concebida como operação causal conjunta e simultânea de componentes. Mas, o equilíbrio interno não significa ausência de relação com externo, ao contrário! A manutenção da proporção ou o equilíbrio entre os constituintes de um indivíduo (ser singular, cujas partes internas conectadas atuam em conjunto e simultaneamente produzindo uma unidade de ação) pode ser obtido somente por mudanças internas contínuas e por relações externas também contínuas, posto que não há nada isolado na natureza, e um corpo, por exemplo, é constituído por relações internas entre seus órgãos e por relações externas com outros corpos. Uma singularidade não é nunca simples (o “simples” é sempre uma abstração), mas complexa e dinâmica, e é pela dinamicidade (operação causal conjunta) que a sua essência se mantém e é definida, não podendo nunca ser universal. Podemos afirmar, portanto, que a singularidade se mantém na tensão interna à coletividade dos seus elementos constituintes, os quais são, por natureza, relacionais. Ou melhor, "a essência de uma coisa é concebível somente post festum, isto é, unicamente a partir do fato da sua existência ou, mais precisamente, a partir da sua potência de agir que nos revela a sua verdadeira 'interioridade'. A barreira entre interior (essentia intima) e exterior (circunstancia, isto é aquilo que está em torno) é abatida; a potência é precisamente a relação regulada de um exterior e de um interior que se constituem na própria relação"214.

Mesmo que cada coisa material se defina por sua estrutura inteligível (relações determinadas de movimento e de repouso), ela comporta também um aspecto dinâmico, enquanto se define pelo conatus que lhe é próprio e que exprime, em um grau determinado, a potência e a vida de Deus. Esse esforço (de corpo e alma) nos seres humanos ocorre tanto na inadequação quanto na adequação. Quando adequado, participamos ativamente da potência divina, de maneira que Ele constitui as nossas idéias, manifestando-se nelas - mais do que partes, tomamos parte no absoluto (Deus), expressando-o. Voltaremos a isso brevemente. Antes, é importante ao menos apontar a diferença entre extensão cartesiana e a espinosana, pois a sua confusão foi responsável pelas críticas mais contundentes de Bergson ao mecanicismo espinosista. Ora, Espinosa reprova o fato de Descartes ter reduzido a extensão a uma matéria inerte, pois, considerada assim, é impossível dela deduzir a existência dos corpos. O movimento (modificação imediata e infinita da extensão) exprime o aspecto dinâmico e constituinte do atributo Extensão, não sendo uma mudança local passível de 
determinação pelas posições sucessivas de um móvel no espaço - ele exprime a mobilidade do ser em suas manifestações materiais. Ora, o mecanicismo, tal como Bergson o compreende, significa uma doutrina segundo a qual as coisas não comportam interioridade, estando ligadas por relações exteriores a condições antecedentes invariáveis. Sendo assim, Espinosa também o rejeita, já que rejeita a divisão da matéria em partes inertes ou simples. É a complexidade simultânea que constitui uma causalidade e define um indivíduo, o qual pode ser tanto um ser humano, um coletivo (constituído como causa única de um mesmo efeito) ou a natureza inteira.

Um ser que não existe por si tem potência própria na medida em que é parte de um todo, ou seja, parte da potência de um ser que existe por si. A potência do homem é uma parte da potência infinita de Deus, mas, nas palavras de Deleuze, a parte se revela irredutível, grau de potência original e distinto de todos os outros. "Somos uma parte da potência de Deus, mas precisamente na medida em que essa potência é 'explicada' por nossa própria essência. Uma participação é sempre pensada como uma participação de potências, o que não suprime a distinção de essências"215. Na filosofia espinosana, toda potência encerra um poder de ser afetado que lhe corresponde e é inseparável dela. Esse poder é sempre e necessariamente preenchido. À potência corresponde uma aptitudo ou potestas. Mas, não há atitude ou poder que não sejam efetuados. Não há potência que não seja atual. Ao fim e ao cabo, ainda de acordo com Deleuze, "Reduzir as coisas a modos de uma substância única não é um meio de fazer delas aparências, fantasmas, como Leibniz acreditava ou fingia acreditar, mas, ao contrário, é o único modo, segundo Espinosa, de fazer delas seres 'naturais', dotados de força ou de potência”216.

A atitude progressiva (da ordem) exclui, portanto, toda ficção e nos faz ir de um ser real a outro, de sorte que o método ${ }^{217}$ é tanto uma teoria da definição genética, como também uma teoria da dedução produtiva. No Tratado da Reforma da inteligência, Espinosa abordara a definição como aquilo que, "para que seja perfeita, deverá explicar a essência íntima da coisa e evitar que ponhamos no lugar dela certas propriedades” (T.R.I., p. 56). Para tanto, ele fizera uso de exemplos da

214 Morfino, Vittorio. “Spinoza: uma ontologia da relação?”; p. 24.

215 Deleuze, G. Spinoza et le problème de l'expression, p. 81.

216 Ibidem, p. 81.

217 Para Deleuze, o método de Espinosa comporta três dimensões, cada uma estreitamente implicada na outra. A primeira diz respeito à finalidade do pensamento, que consiste menos em conhecer algo do que em conhecer nossa potência de conhecer. A segunda se refere ao meio de realizar essa finalidade, ou seja, a partir de uma idéia verdadeira dada, devemos fazer dela uma idéia adequada (“a adequação constitui a matéria do verdadeiro") - a idéia adequada é expressiva - e, sob esse segundo aspecto, o método é genético: "determinamos a causa da idéia como a razão suficiente de todas as propriedades da coisa”. Essa segunda parte nos conduz ao mais alto pensamento, ou seja, à idéia de Deus. E, por fim, a terceira parte diz respeito à unidade da forma e do conteúdo, da finalidade e do meio. "Entre a idéia e a idéia da idéia há apenas uma distinção de razão: a idéia reflexiva e a idéia expressiva são uma só e mesma coisa em realidade" (Cf. Spinoza et le problème de l'expression, p. 125). 
geometria, mostrando que as figuras podem ser definidas por uma causa próxima ou ser objeto de definições genéticas. Assim, o círculo, que também encontramos no escólio de E II, P7 é utilizado como "um exemplo, de uma coisa abstrata, que é indiferente que seja definida de um modo ou de outro [...] porque se este se define como uma certa figura em que as linhas tiradas do centro à periferia são iguais, ninguém deixará de ver que essa definição não explica, de modo algum, a essência do círculo, mas somente uma propriedade dele” (T.R. I., p. 56). A definição do círculo, por sua vez, demonstra-nos a sua produção pelo movimento (a partir de uma linha qualquer, da qual uma extremidade é fixa e a outra móvel), fazendo com que as suas propriedades (tal como a igualdade das linhas que vão do centro à periferia) dela decorram ou possam ser deduzidas. O que nos importa aqui é salientar que se trata de um “exemplo de uma coisa abstrata” que nos permite clareza sobre a diferença entre propriedades e definição, mas que têm seus limites justamente porque se trata de algo abstrato e não de seres físicos ou reais, como vemos na sequência do texto: "E ainda que, como já disse, a respeito de figuras e de outros seres de razão isto pouco importa, contudo importa muito no que respeita a seres físicos e reais, pois que não se podem entender as propriedades das coisas enquanto se ignoram suas essências; se, pois, omitimos as essências, necessariamente pervertemos a concatenação da inteligência, que deve reproduzir a concatenação da Natureza, e nos afastaremos inteiramente de nosso escopo” (T.R.I., p. 56). O recurso aos "seres de razão” ou às figuras da matemática não deve, portanto, ser entendido como limitação para a filosofia, mas, ao contrário, como instrumento de explicação determinado (e não determinante) e que, com o escopo do método (conhecer as essências), tem inclusive o seu domínio ampliado (o círculo deixa de ser considerado a partir de suas propriedades, para ser compreendido por aquilo que o define). Assim, a geometria do sistema deve ser compreendida a partir da ordem ou estrutura da realidade a que ela se refere. Ou, nas palavras de Chaui, “as discussões em torno da demonstração espinosana giram à volta do termo geometricus, deixando na sombra o termo ordo. Dessa maneira, costuma passar despercebido que 'geométrico' é um adjetivo qualificativo de 'ordem', esta sim, um substantivo” ${ }^{218}$. No escólio de E II, P7, ao tomar o exemplo do círculo, Espinosa o remete àquilo que fora dito no Tratado da Reforma da Inteligência, ou seja, à consideração de que a definição dos modos (círculo e sua idéia) deve compreender a causa próxima, a qual nos remete à estrutura causal da substância (ordem da realidade, do conhecimento e da vida).

Ora, para conhecer a idéia de uma coisa ou a sua definição deve-se conhecer a sua causa eficiente, e é esta que nos permite ter uma idéia adequada dela (diferente de uma idéia verdadeira, na

218 Chaui, M., op. cit., p. 565. 
qual se indica o acordo entre ela e o seu objeto). De acordo com Chaui: “Adequada é a idéia verdadeira que, oferecendo a causa ou razão total de si mesma, permite deduzir ou demonstrar a totalidade das propriedades que possui e, portanto, seus nexos necessários com todas as outras de que depende ou que dela dependem”. E, se “as idéias são verdadeiras, é porque sua concatenatio é imanente e a geometria, maneira exemplar de apresentar essa articulação dedutiva imanente”219. Desta sorte, a matemática, buscando definições (essências) e propriedades, e não fins para as coisas, é um instrumento para o filosofar na “devida ordem”, porque coloca o espírito "sob uma outra norma da verdade” (E I, apêndice), que não a da imaginação, exemplificando a maneira como alcançamos (podemos alcançar) um conhecimento certo ou evidente ${ }^{220}$. E é por utilizá-la dessa “maneira exemplar”, para apresentar nada menos que a “articulação dedutiva imanente” (grifo nosso), que seu uso se distingue do de Descartes, de maneira a não cair na linearidade sequencial da criação contínua mantida por um Deus sumamente perfeito. O exemplo do círculo mostra, pois, a necessidade do conhecimento da causa imanente (pela causa próxima), evidenciando também que a definição de Deus como ser sumamente perfeito (definição cartesiana) não permite deduzir todas as propriedades desse ser, pois não exprime a causa eficiente, que, neste caso, se refere a algo incriado $^{221}$ (é causa de si). E enquanto, para Descartes, a ordem são "séries ininterruptas de razões cujo ponto de partida é uma intuição evidente ou uma natureza simples que não pode ser definida, Espinosa contrapõe a idéia de ordem como concatenação imanente cujo ponto de partida é uma definição e cujo desdobramento é a articulação de todas as idéias entre si e de todas as coisas entre si”222. Dizer que a ordem e conexão é a mesma não remete de nenhuma maneira a uma sequência linear de encadeamento que se repetiria em todos os atributos, tendo como garantia um ser externo à sequência das causas, o Deus cartesiano. A causalidade é imanente e complexa, num entretecimento de relações, e as coisas (modos da extensão ou as que são modos do pensamento) só podem ser percebidas por outro modo "como causa próxima, e este, por sua vez, por outro, e assim ao infinito". Ao final do escólio, retomaremos a especificidade da "causa próxima” nessa filosofia da imanência. Antes, é necessário uma última referência ao papel da matemática na obra espinosana.

Segundo Chaui, “uma primeira (e constante) referência à matemática aparece na obra espinosana toda vez que se trata de contrapor o que é objeto de crença ao que é objeto de

219 bidem, p. 566.

220 Segundo Moreau, a partir do texto citado, podemos ver que "há outros meios de se iniciar na sabedoria. O apêndice do livro I diz, aliás, 'as matemáticas e outras causas ainda'. Mas, se as matemáticas podem servir de modelo é porque elas indicam melhor a aspiração ao reconhecimento da necessidade” (cf. Moreau, Pierre-François, Spinoza:l'expérience et l'éternité. Paris: 1994; p. 499).

221 Sobre os requisitos para a “definição de uma coisa incriada”, conferir o T.R.I., p. 57.

222 Chaui, M. op., cit., p. 566. 
ciência” $^{223}$. Esta citação se insere na explicação que a autora fornece do uso da matemática no Teológico-político, mostrando a distinção entre certeza religiosa e certeza matemática, na qual “encontra-se a diferença entre um conhecimento que depende de algo externo ou de uma coisa qualquer e o conhecimento auto-suficiente”. Consideramos que isto nos permite afirmar que, nesse sentido (apesar das diferenças que separam os interesses de Descartes dos teológico-políticos), o Deus cartesiano também está mais para objeto de crença que de ciência. Da mesma maneira, podemos ver que, no Prefácio da Parte III da Ética, Espinosa cita a tentativa do “celebérrimo Descartes” de demonstrar "o caminho pelo qual a alma pode adquirir um império absoluto sobre as afecções”, sem êxito, e a esta tentativa malograda (mencionada novamente no Prefácio da Parte V, que citamos em nosso primeiro capítulo, no qual a idéia da glândula pineal é vista como obscuridade por parte de alguém que dizia se guiar apenas pela clareza e distinção), o autor da Ética afirma que tratará da "natureza e da força das afecções, e do poder da alma sobre elas, com o mesmo método com que nas partes precedentes [tratou] de Deus e da alma, e [considerará] as ações e apetites humanos como se tratasse de linhas, superfícies e volumes” (E III, prefácio; grifo nosso). Isto não significa seguramente que Deus, a alma e as afeç̧ões sejam seres matemáticos (seres de razão, não físicos ou reais como exposto no T.R.I.), e sim que o seu tratamento é feito não pela exterioridade ou pela ridicularização (no caso dos afetos), mas de acordo com a auto-suficiência do conhecimento adequado, como citamos logo acima. Os elementos da matemática não substituem os seres reais. Neste sentido, geometria e experiência (física e psicológica, nos termos de Bergson na crítica da idéia do Nada) se excluem, ainda que possam ser complementares no sentido a que nos referimos. Assim, Espinosa, como Bergson afirma, foi mais longe que Descartes. Porém, não o fez na mesma direção, ou seja, não seguiu simplesmente a mesma tendência, radicalizando-a pela geometrização do sistema. E é na direção por ele criada que a existência finita (e, consequentemente, a liberdade dos seres finitos) não dependerá do recurso a um ser externo, criador e mantenedor da criação a cada instante da duração. À liberdade espinosana, a qual não se separa do sentimento da nossa eternidade, voltaremos após a finalização do escólio de E II, P7.

Vejamos, então, as palavras que o findam e como elas nos levam a uma leitura que retira toda eminência da filosofia da imanência (importante para desfazer a confusão entre Espinosa e Plotino, outro avatar da crítica bergsoniana):

Por isso Deus, enquanto consiste em infinitos atributos, é verdadeiramente causa das coisas como são em si.

223 Ibidem, p. 601. 
Dizer que Deus é “causa das coisas como são em si” significa que Ele é causa de suas essências e existências ${ }^{224}$, produzindo-as como realidades singulares e potências causais que, contudo, Dele diferem quanto à essência e à existência, como tivemos oportunidade de mencionar. Assim, a imanência não significa uma repetição ou dissolução de essências, anulando as individualidades, e sim a realidade como produção diferenciada. Como sabemos, os atributos constituem a essência da substância, e Deus não constitui a essência dos modos ${ }^{225}$. Isto, por sua vez, não significa que Deus não tenha nada formalmente em comum com as criaturas, se considerarmos que, nas palavras de Deleuze, “as mesmas formas se afirmam de Deus e das criaturas”, embora um e outras difiram em essência e existência. “Os atributos são, portanto, formas comuns a Deus, do qual eles constituem a essência, $e$ aos modos ou criaturas, que os implicam essencialmente”226 . Ainda de acordo com Deleuze, consideramos que, enquanto refutamos a comunhão formal, confundimos as essências por analogia (a essência das criaturas seria análoga à de seu criador, embora finita), mas, desde que colocamos a comunhão formal, damo-nos o meio de distingui-los. As singularidades distinguem-se na e da substância, embora façam um com ela, sejam suas maneiras de ser, e possam tomar parte dela pela potência causal que também as define. E disto decorre a distinção entre imanência e emanação, pois que Deus produza "as coisas tais como são em si mesmas significa que elas são produzidas Nele segundo as leis imanentes da Natureza e não a partir Dele numa sequência de seres engendrados uns pelos outros, como na procissão emanativa”227.

Na imanência, a distinção de essência não exclui a igualdade de ser, ou seja, o mesmo ser permanece em si na causa e no efeito, que permanece em outro (na substância). Para Plotino, que Bergson comparara com Espinosa, o Um é causa primeira, dá o ser a tudo o que é, permanecendo, ao mesmo tempo, como algo além, superior aos seus efeitos. “Assim, a emanação, em seu estado puro, não é separável de um sistema Um-superior ao ser; a primeira hipótese do Parmênides domina todo o neo-platonismo. E a emanação não é, além do mais, separável de uma teologia negativa, ou de um método de analogia que respeita a eminência do princípio ou da causa” ${ }^{228}$. A emanação serve de princípio, portanto, a um universo hierárquico, concebendo a diferença dos seres como diferença

224 “Deus não é somente causa eficiente da existência das coisas, mas também da essência delas” (I, P25).

225 “À essência do homem não pertence o ser da substância; por outras palavras, a substância não constitui a forma do homem” (II, P10). "Efetivamente, o ser da substância envolve a existência necessária (pela proposição 7 da parte I); portanto, se o ser da substância pertencesse à essência do homem, dada a substância, também o homem seria necessariamente dado (pela definição 2 desta parte) e, consequentemente, o homem existiria necessariamente, o que (pelo axioma 1 desta parte) é absurdo. Portanto, etc” (demons.II, P10).

226 Deleuze, G. Spinoza et le problème de l'expression, p. 38; grifo nosso.

227 Ibidem, p. 597. 
hierárquica: cada termo é como a imagem do termo superior que o precede e se define pelo grau de distanciamento que o separa da causa primeira. Isto é completamente diferente de uma teoria do Ser que exige a igualdade pela posição de um Ser-igual (igual em si e igualmente presente em todos os seres), de modo que a causa é igualmente próxima em todos os lugares, não havendo causa distante. “Os seres não são definidos por seu rang em um hierarquia, não são mais ou menos distantes do Um, mas cada um depende diretamente de Deus, participando da igualdade do ser, recebendo imediatamente tudo o que pode Dele receber de acordo com a aptidão de sua essência, independentemente de toda proximidade e de toda distância”229. A imanência, não suprimindo a distinção de essência entre Deus e "as criaturas”, exige a univociade do Ser, isto é, formas comuns, que constituem a essência da substância como causa, e contêm as essências dos modos enquanto efeitos. Assim sendo, a superioridade da causa subsiste do ponto de vista da imanência, mas não gera nenhuma eminência, ou seja, nenhuma posição de um princípio além das formas que estão, elas próprias, presentes no efeito $^{230}$. Por fim, imanência não significa ausência de diferença ou indiferenciação entre Deus e as coisas (ou entre Ele os homens) como supuseram alguns leitores e, dentre eles, Bergson.

Liberdade e plenitude afetiva no conhecimento sub specie aeternitatis

"Se, agora, formos à busca das consequências mais importantes das proposições II, P7, II, P40 231, iremos encontrá-las na Parte $\mathrm{V}$ da Ética, dedicada à liberdade e à felicidade [...]. A reformulação das proposições da Parte II nas da Parte V é o laço que enlaça ordem da Natureza,

228Deleuze, G. Spinoza et le problème de l'expression, p. 156.

229 Ibidem, p. 157.

230 "A imanência se opõe a toda eminência da causa, a toda teologia negativa, a todo método de analogia, a toda concepção hierárquica do mundo. Tudo é afirmação na imanência. A Causa é superior ao efeito, mas não superior ao que ela dá ao efeito. Ou, de preferência, ela não 'dá' nada ao efeito. A participação deve ser pensada de maneira inteiramente positiva, não a partir de um dom eminente, mas a partir de uma comunidade formal que deixa subsistir a distinção de essências" (Deleuze, Spinoza et le problème de l'expression”, p. 157). E mais adiante: "A imanência é precisamente a vertigem filosófica, inseparável do conceito de expressão (dupla imanência da expressão no que se exprime e do expresso na expressão)" (p. 163-4; grifo nosso).

231 Sabemos que a proposição E II, P40 apresenta os gêneros de conhecimento, a saber: imaginativo, racional e intuitivo. O primeiro gênero se refere a duas maneiras de conhecer inadequadamente, por meio das quais formamos noções universais: 1) a partir de singulares, apresentados de maneira confusa e mutilada ao nosso intelecto (percepção que se adquire por experiência vaga, a qual não é determinada pelo intelecto); 2) a partir de signos, formando uma percepção que temos pelo ouvir ou por outro sinal designado convencionalmente, e cuja recordação nos leva a formarmos idéias semelhantes àquelas pelas quais imaginamos as coisas. O conhecimento do segundo gênero é um conhecimento racional pelo qual alcançamos as noções comuns, ou propriedades presentes em todas as coisas, e que nos permite formar idéias verdadeiras. O terceiro gênero, ou ciência intuitiva, por sua vez, "procede da idéia adequada da essência formal de certos atributos de Deus para o conhecimento adequado da essência das coisas” (E II, P40esc.2). 
ordem do conhecimento e ordem da vida, ou, se preferirmos, a experiência ética propriamente dita”232. A Parte V aborda, como sabemos, “A potência do intelecto ou a liberdade humana”, e é nela que se encontra a famosa afirmação sobre a experiência da eternidade, citada por Bergson na carta em que se encontra a não menos famosa afirmação segundo a qual "todo filósofo tem duas filosofias: a sua e a de Espinosa” ${ }^{233}$. Nesta carta, escrita a Léon Brunschivcg, em 12 de fevereiro de 1927, por ocasião da comemoração do aniversário de duzentos e cinquenta anos da morte de Espinosa, Bergson considera que, apesar de Aristóteles ter feito bem em dizer que não devíamos nos apegar ao que é humano e mortal, e sim, que devemos, tanto quanto isto é dado ao homem, viver na imortalidade, estava reservado a Espinosa "mostrar que o conhecimento interior da verdade coincide com o ato intemporal pelo qual a verdade se põe e nos faz 'sentir e experimentar a nossa eternidade’”234. Vejamos o que essa experiência significa, na perspectiva de leitura que estamos seguindo (explicada acima), antes de interrogar o que a carta pode nos dar a refletir, o que faremos nas nossas considerações finais.

A primeira proposição da Parte V da Ética afirma que: "É exatamente da mesma maneira que se ordenam e se concatenam os pensamentos e as idéias das coisas na mente que também se ordenam e se concatenam as afecções do corpo, ou seja, as imagens das coisas no corpo” (E V, P1). Em sua demonstração, ela invoca a proposição II, P7, fundamento ontológico da reflexão, como vimos. Ambas afirmam a perfeita simultaneidade entre o que se passa na mente e no corpo, sem que haja hierarquia entre um e outro, pois são modos de atributos distintos. A reformulação dos termos de II, P7 na E V, P1 indica que o terreno a ser trilhado agora é o da reflexão, da idéia da idéia da mente, ou o campo da mente internamente disposta. Isto porque, enquanto a proposição II, P7 diz que a “ordem e conexão” é a mesma, a proposição E V, P1 afirma a mesma maneira pela qual “se ordenam e se concatenam” as idéias na mente e as afeções no corpo. Para compreender o significado de tal mudança, utilizaremos o esclarecedor artigo de Vittorio Morfino, “O primado da conexão sobre a série”, no qual é feita a distinção entre os termos series, connexio e concatenatio. Após explicar o uso do termo "série” no Tratado da Reforma da Inteligência, de que não trataremos aqui, Morfino afirma que esse termo desaparece inteiramente da Ética, “enquanto a palavra 'ordo' permanece como eixo central da ontologia espinosana”235. Assim, em lugar da identificação entre “ordem” e "série”, na

\footnotetext{
232 Chaui, M. op. cit, p. 599.

233 BERGSON, H., Ecrits et paroles. Paris: Presses Universitaires de France, 1957; p. 587.

234 Id., ibid, p. 587.

235 Haveria uma única ocorrência, insignificante a seus olhos. A esse respeito, conferir "O primado da conexão sobre a ordem” in Jaquet, C.; Sévérac, P.; Suhamy, A. (orgs.) La théorie spinoziste des rapports corps/esprit et ses usages actuels. Paris: Hermann Éditeurs, 2009; p. 87.
} 
Ética o que se faz presente é a identidade entre “ordem” e “conexão”, desenvolvendo uma concepção da causalidade como encadeamento complexo, numa metáfora têxtil que invoca outra coisa que uma sequência serial e linear como na série causa-efeito ${ }^{236}$. Contudo, a Ética não substitui apenas um termo por outro (series por connexio), ela coloca igualmente em evidência “os motivos, o mecanismo, em função dos quais os homens são conduzidos a se representar a realidade de maneira inadequada como uma cadeia serial que se desenvolve ao longo de uma linha reta temporalmente”237. É isso que nos interessa agora, para fazer a última contraprova da crítica de sorte a diferenciar as durações reais e as suas representações imaginárias, ou seja, a distinguir o tempo, tomado como sequência (pela imaginação), tanto da duração, que concerne aos modos finitos (e, portanto, a nós seres humanos reais) quanto do conhecimento do entrelaçamento complexo das relações que constituem as essências singulares, e pelo qual podemos “sentir e experimentar” a nossa eternidade. O que nos importa primeiramente enfatizar é a maneira como Espinosa demonstra que a sequência dos acontecimentos numa reta temporal - na qual separamos instantes e instituimos uma sucessão cronológica pela divisão da linha em passado, presente e futuro - significa uma reificação do tempo, nas palavras de Morfino, fazendo dele "um objeto imaginado dentre outros, de tal sorte que é, então, possível instaurar uma relação entre o instante vazio da percepção e seu conteúdo (como se o instante pudesse existir em si, independentemente do encontro que o constitui)” ${ }^{\text {,238 }}$. Para tanto, faz-se necessária a citação de E II, P44, na qual esse processo é evidenciado e em cujo escólio são invocadas as proposições E II, P17 e E II, P18, as mesmas que Bergson citara no curso sobre a “História das teorias da memória”, finalizando a explicação pela afirmação de que ali estaria o germe do associacionismo. Antes, é preciso apontar que a proposição E II, P44 afirma que "Não é da natureza da Razão contemplar as coisas como contingentes, mas como necessárias”, e a sua demonstração explica que isto significa "perceber as coisas verdadeiramente, quer dizer, como elas são em si mesmas”. Isto é importante porque mostra que a necessidade não é uma determinação exterior. E, no corolário, lemos que "Daí segue depender da só imaginação que contemplemos as coisas, tanto a respeito do passado quanto do futuro, como contingentes”. O escólio, portanto, nos permitirá entender o que é o processo de reificação do tempo, o qual nos faz imaginar a contingência, lançando outro olhar sobre a necessidade das coisas. Nele, lemos que:

236 Sobre a diferença entre o encadeamento serial e a conexão como entretecimento, remetendo à mudança de perspectiva entre o Tratado e a Ética, conferir o artigo citado. Mesmo não tendo feito tal distinção (entre as duas obras), quando tratamos da causalidade imanente à ordem e conexão dos modos dos atributos (II, P7), pensamos ter apontado algo que segue na mesma direção, pelo tratamento dado à conexão.

237 Morfino, V. "Le primat de la connexion sur la série”, p. 91.

238 Ibidem, p. 91. 
Explicarei em poucas palavras de que maneira isso ocorre. Mostramos acima (prop. 17 desta parte com seu corol.) que a Mente, ainda que as coisas não existam, imagina-as todavia sempre como presentes a si, a não ser que ocorram causas que excluam a existência presente delas. Ademais (prop. 18 desta parte) mostramos que, se o Corpo humano uma vez tiver sido afetado simultaneamente por dois corpos exteriores, quando depois a Mente imaginar um deles, de imediato recordar-se-á também do outro, isto é, contemplará a ambos como presentes a si, a não ser que ocorram causas que excluam a existência presente deles. Além disso, ninguém duvida que imaginemos também o tempo a partir do fato de imaginarmos que os corpos se movem uns mais lentamente que outros, ou mais rapidamente, ou com igual rapidez. Suponhamos, pois, um menino que pela primeira vez ontem pela manhã tenha visto Pedro, ao meio-dia Paulo e ao entardecer Simeão, e que hoje de novo pela manhã tenha visto Pedro. Pela proposição 18 desta parte [Se o Corpo humano tiver sido afetado uma vez por dois ou mais corpos em simultâneo, quando depois a Mente imaginar um deles, imediatamente se recordará dos outros] é patente que tão logo veja a luz matutina, imaginará o sol percorrendo a mesma parte do céu que no dia anterior, ou seja, um dia inteiro, e simultaneamente com o amanhecer imaginará Pedro, com o meiodia Paulo e com o entardecer Simeão, isto é, imaginará a existência de Paulo e de Simeão com relação ao tempo futuro; e pelo contrário, se ao entardecer vir Simeão, relacionará Paulo e Pedro ao tempo passado, a saber, imaginando-os simultaneamente com o tempo passado; e isto com tanto mais constância quanto com mais frequência os tenha visto nesta ordem [...].

Para o que exporemos, é importante ter em mente o que afirma o escólio de E II, P18:

\begin{abstract}
Daqui claramente inteligimos o que seja a Memória. Com efeito, não é nada outro que alguma concatenação de idéias que envolvem a natureza das coisas que estão fora do Corpo humano, a qual ocorre na mente segundo a ordem e a concatenação das afecções do Corpo humano. Digo, primeiro, ser essa concatenação apenas daquelas idéias que envolvem a natureza das coisas que estão fora do Corpo humano, e não das idéias que explicam a natureza dessas mesmas coisas. Pois, em verdade, são (pela prop. 16 desta parte) idéias das afecções do Corpo humano, que envolvem tanto a natureza dele quanto a dos corpos exteriores. Digo, segundo, ocorrer essa concatenação das afecções do Corpo humano, para distingui-la da concatenação de idéias que ocorre segundo a ordem do intelecto, pela qual a mente percebe as coisas por suas causas primeiras e que é a mesma em todos os homens.
\end{abstract}

Importa-nos ressaltar no escólio de E II, P44, de acordo com Morfino, a imagem da linha reta ou, mesmo, circular do tempo, segundo o trajeto do sol (manhã, tarde e noite), de maneira a fazer dos encontros fortuitos um modelo normativo que inscreve hábitos e, também podemos dizer, expectativas que, na perspectiva bergsoniana, da qual tratamos no segundo capítulo, corresponde ao 
vocabulário do negativo, ou seja, da espera e da frustração - o que significa não ver as coisas “como são em si”, mas como gostaríamos que fosse, quer dizer, de acordo com a nossa imaginação, no vocabulário espinosano. O que “as coisas são em si” diz respeito ao entretecimento das durações reais numa ordem complexa que é irredutível ao encadeamento serial dos acontecimentos. Logo, “a representação imaginária dessa ordem produz necessariamente uma imagem inadequada da temporalidade sob a forma de uma sucessão de instantes vazios que preenche o conteúdo perceptivo, efeito do encontro do corpo e de seu meio ambiente»"239. Pelo escólio de E II, P18, vemos que essa representação imaginária do tempo se faz pela “concatenação apenas das idéias que envolvem a natureza das coisas que estão fora do Corpo humano, e não das idéias que explicam a natureza dessas mesmas coisas” (grifo nosso), de maneira que há uma diferença entre a ordem e concatenação conforme as afecções do corpo (que envolvem, ou seja, pressupõem a natureza do corpo e dos corpos exteriores) e a ordem e concatenação das idéias conforme o intelecto (que "explicam a natureza dessas mesmas coisas” ou pela qual a mente as percebe "por suas causas primeiras”). No primeiro caso, temos um conhecimento inadequado, enquanto no segundo, ele é adequado, e isto porque a concatenação é distinta, num e noutro caso. E a sua distinção é fundamental porque, na concatenação conforme a ordem do intelecto, o que explica a natureza das coisas são as suas “causas primeiras” e estas, como já dissemos, não ocorrem na sequência mecânica causa-efeito, mas na conexão complexa de entrelaçamento pela qual a realidade é estruturada. Assim, se voltarmos à proposição $\mathrm{V}, \mathrm{P} 1$, que afirma a reversibilidade e simultaneidade entre o que se passa na mente e no corpo (a mesma ordem e concatenação), a sua demonstração invoca II, P7, a qual, como afirmamos é primordialmente ontológica e que, portanto, fundamenta a reflexão, de maneira que, neste sentido, nos colocamos de acordo com Morfino, quando afirma que, “enquanto o termo conexio é reservado à dimensão ontológica do discurso, o termo concatenatio pertence ao nível epistemológico”, lembrando “a identidade na epistemologia espinosana entre o aspecto cognitivo e o aspecto emotivo" $^{240}$, como veremos a seguir.

Ora, na sequência do conjunto da proposição E V, P1, vemos o que é passar da inadequação (causalidade externa) à adequação (causalidade interna) e que isso não significa sair do campo afetivo, ainda que signifique, o que é importantíssimo, sair da “flutuação de ânimo” ou do domínio das paixões. Assim, lemos em E V, P2 que: "Se separamos uma emoção do ânimo, ou seja, um afeto, do pensamento de uma causa exterior, e a ligamos a outros pensamentos, então o amor ou o ódio para com a causa exterior, bem como as flutuações de ânimo, que provêm desses afetos, serão

239Ibidem, p. 92. 
destruídos”. E, em E V, P3: “Um afeto que é uma paixão deixa de ser uma paixão assim que formamos dele uma idéia clara e distinta”. Um afeto deixa de ser uma paixão, mas não deixa de ser afeto: a sua qualidade muda de passiva para ativa (o que não está posto no contexto dessa proposição, mas que adiantamos porque não nos compete aqui a análise de todas as proposições da Ética). Um afeto da mente é uma idéia e por isso não há entre a idéia clara e distinta que formamos e o próprio afeto, “enquanto referido exclusivamente à mente, senão uma distinção de razão”, como vemos na demonstração de E V, P3. Sabemos que, para Espinosa, as coisas não são boas ou más em si mesmas e não escolhemos uma coisa por ser boa ou má, mas, ao contrário, “dizemos que é boa porque a desejamos” (E III, P39esc.) - a qualidade das coisas depende de nosso desejo. E, como o desejo é o apetite do qual temos consciência (E III, P9esc.) - é uma idéia ou um afeto da mente -, o que está em questão aqui é uma mudança de conexão: ao invés de ligar o afeto a causas externas, ligá-lo a outros afetos que são idéias, ou seja, a uma causa interna. E ainda, como o desejo é “a própria essência ou natureza de cada um, à medida que ela é concebida como determinada, em virtude de algum estado preciso de cada um, a realizar algo” (E III, P56), a mudança de qualidade do nosso desejo (o que significa mudar o objeto ao qual nos ligamos pelo desejo ou estarmos atentos à qualidade do objeto ao qual nos ligamos pelo desejo) nos fará passar da paixão (passividade) para a ação (atividade afetiva). Destarte, voltando ao texto de Morfino, podemos afirmar que "todo esforço da razão e do intelecto vai consistir precisamente em tentar quebrar essa ordem simples e linear a fim de restituir no plano das idéias, a partir de uma nova concatenatio, a complexidade das relações entre as coisas”241. Vale ressaltar ainda que, no que diz respeito ao conhecimento verdadeiro das afecções corporais e psíquicas, o mais importante está no fato de que Espinosa não introduz idéias não afetivas, que controlariam o processo reflexivo, o que faria dele um intelectualista, tal como Bergson o viu. Enquanto na imaginação, há uma concatenação dependente de causas exteriores, na reflexão, há uma conexão interna de idéias/afetos que a mente realiza (é causa) continuamente, e cujo nexo (entre os afetos) não ocorre em sequência ou com elementos isolados, e sim numa continuidade de mudança qualitativa (a qualidade dos afetos muda, não é estática). Essa contínua mudança qualitativa não significa flutuação do ânimo, a qual ocorre justamente quando a mudança está ligada às alterações externas. As idéias inadequadas ou imaginativas são as que envolvem a natureza do corpo, dos corpos exteriores e da mente, mas desconhecem ou não exprimem a natureza de cada um deles, ou seja, são idéias que não podem ser explicadas (deduzidas) apenas pela natureza ou potência da mente - são dependentes do meio ambiente ou do mundo circundante. A idéia adequada, ao

240Ibidem, p. 93. 
contrário, exprime a essência do corpo, dos corpos exteriores e da mente, assim como também exprime as relações ordenadas e concatenadas entre os corpos e as idéias, explicando-se (deduzindose) exclusivamente pela potência da mente que, formulando-a, manifesta a sua verdadeira potência.

A filosofia de Espinosa não é um intelectualismo (o processo reflexivo não é regulado por idéias não afetivas), nem um materialismo, que considera o físico a causa do psíquico. Não há uma hierarquia, como apontamos, entre os dois âmbitos, um se sobrepondo ao outro, e, neste sentido, não é um dualismo, ainda que a ordem e a concatenação das coisas e das idéias seja a mesma. Tratase de uma igualdade que não é redução de um âmbito ao outro, nem identificação de seus constituintes. Seria um monismo? Não, se considerarmos que este se define pela ausência de diferença, e aqui não se trata de negar a diferença, mas, ao contrário, de afirmá-la ${ }^{242}$. Como pode haver igualdade com a manutenção da diferença? Justamente porque não se trata de identidade, nem de causalidade matemática entre atributos distintos, o que levaria à inclusão de um no outro ${ }^{243}$. $\mathrm{O}$ nexo de idéias que a mente realiza na reflexão, que é um nexo de afetos em mudança qualitativa, também não significa causalidade matemática, no âmbito da mente, ou de uma distribuição espacial das idéias que estão sendo conectadas. Se não se pensar externamente, ou seja, a mente como algo externo às idéias que ela ordena, regula e controla, mas se se tiver em mente que ela é a idéia do corpo e a idéia da idéia, tanto quanto é o processo, que ela não se distingue da idéia que ela é244, e, ainda, se se levar em consideração que toda idéia ou pensamento é afeto e que cada afeto é qualidade, então, não há nenhuma razão para se afirmar uma espacialidade ou causalidade matemática das idéias ou afetos, ou uma correspondência ponto por ponto entre séries.

Sabemos que, para Espinosa, uma idéia verdadeira é índice de si mesma e do falso e, ainda,

241Ibidem, p. 93.

242 Segundo Axel Cherniavsky, pode-se falar em dualismo em Bergson, desde que não seja o cartesiano, e, também em monismo, desde que não seja o espinosano. "?Qué significa entonces que Bergson tiene dos filosofías, la propia y la de Spinoza? Significa, pues, que pretende lograr una nueva forma de monismo, ni mecanicista ni paralelista; una nueva forma de dualismo, ni sustancial ni causal” (Cf. "Vieja, muy vieja mercadería.” Spinoza y Bergson. Octubre 2004. Córdoba; grifos nossos). Não discordamos de sua caracterização da filosofia bergsoniana (nova forma de monismo e nova forma de dualismo), mas lamentamos que esse novo monismo (nem mecanicista, nem paralelista) seja comparado e contraposto ao espinosista, sem fazer a crítica dessa leitura, pelo contrário. Assim, o que o texto ganha com Bergson (ou para Bergson), perde em Espinosa.

243 Segundo Morfino, no texto “Spinoza: uma ontologia da relação?”, “As relações de identidade, diferença, oposição etc não são nada que entia rationis que têm o mérito de ajudar na classificação destas verdadeiras e próprias connexiones singulares que são os indivíduos: classificação que, todavia, se fundamenta sobre a imaginação e memória, e nã o sobre a razão” (cf. o mencionado artigo, p. 34).

244 “A idéia da Mente e a própria Mente é uma só e a mesm coisa, que é concebida sob um só e o mesmo atributo, a saber, o do Pensamento. Insisto dar-se que a idéia da Mente e a própria Mente se seguem em Deus com a mesma necessidade da mesma potência de pensar. Pois, em verdade, a idéia da Mente, isto é, a idéia da idéia, nada outro é que a forma da idéia enquanto esta é considerada como modo de pensar sem relação com o objeto; com efeito, assim que alguém sabe algo, por isso mesmo sabe que sabe isso e, simultaneamente, sabe saber o que sabe, e assim ao infinito” (esc. IIP21; tradução do Grupo de Estudos Espinosano da Universidade de São Paulo). 
quem tem uma idéia verdadeira sabe que a tem, o que significa que, ao termos uma idéia verdadeira, podemos ligá-la a outra, ou melhor, o nosso modo ordinário de ver as coisas e o mundo muda e, ao mudar, possibilita que mudemos outros pensamentos ou idéias a partir de novas relações. Isto não significa um desprezo pela imaginação ou pela memória, a qual nos leva à expectativa de encontros não realizados (na sequência linear do tempo reificado), e sim uma distinção dos domínios do conhecimento. A imaginação não é uma deficiência, ao contrário. O problema está em fazer dela uma norma para nossa conduta, regulando exclusivamente por suas leis (ordenamento que lhe é próprio) o nosso conhecimento e, então sim, caímos no vazio ou desconsolo do ausente, ignorando, digamos, a plenitude da presença. Ao transformarmos um afeto passivo em ativo, suspendemos a dependência do conatus em relação às coisas externas e também, consequentemente, ao desejo de outros seres humanos - e é isso define a potência de uma mente internamente disposta. Quanto menos dependente de causas e coisas externas, mais se é autônomo e livre. Tal possibilidade de ordenamento das idéias/afetos, distinto do ordenamento imaginário, é aquilo em que consiste o esforço de liberação da filosofia espinosana ${ }^{245}$. Suspender a dependência das causas externas não significa, para a mente, deixar de ser o que ela é, ou seja, idéia do corpo e idéia dessa idéia. Não significa também, para o corpo, deixar de ser o que ele é, uma estrutura de ações e reações que pressupõem a inter-corporeidade originária; pois uma mente é tanto mais disposta quanto mais apto é seu corpo para múltiplas e simultâneas coisas (para a conservação, regeneração e transformação em suas complexas relações com outros corpos) - Somos ativos de corpo e alma. Significa um saber que se sabe, isto é, consciência de si como potência imaginante e como consciência dessa consciência (reflexão), a qual depende apenas dela ou de sua essência pensante (de sua ação). Isto (a não dependência de causas externas ou do desejo de outros) nos faz mais fortes, pois fortalece o nosso conatus, ou seja, a nossa essência enquanto seres singulares, força interna que unifica nossas operações e ações para nos mantermos (perseverarmos) na existência, de corpo e mente. Mais ainda: ao conectarmos as idéias adequadamente, explicando-as (deduzindo), um sentimento se produz em nós, a certeza ou ressonância interna do verdadeiro em nosso intelecto. No Tratado da Reforma da Inteligência, Espinosa afirmara que "a certeza não é senão a mesma essência objetiva, isto é, como sentimos a essência formal é a própria certeza” e que “daí segue-se, mais uma vez, que para a certeza da verdade nenhum outro sinal é necessário: basta ter a idéia verdadeira” (T.R.I., p. 22; grifo nosso). Nenhum sinal exterior é necessário para a certeza, pois, quem tem uma idéia verdadeira sabe que a tem, quer dizer, trata-se de uma certeza intrínseca (como na matemática), que é acompanhada da

245 Morfino, V. “Le primat de la connexion sur la série”, p. 93. 
idéia de si como causa - isto é o que toda demonstração implica. É esse sentimento que encontramos no escólio da proposição E V, P23. Esta diz que "a mente humana não pode ser inteiramente destruída juntamente com o corpo: dela permanece algo, que é eterno”. E, em seu escólio, lemos que:

\begin{abstract}
Essa idéia que exprime a essência do corpo sob a perspectiva da eternidade é, como dissemos, um modo definido do pensar, que pertence à essência da mente e que é necessariamente eterno. Não é possível entretanto, que nos recordemos de ter existido antes do corpo, uma vez que não pode haver, nele, nenhum vestígio dessa existência, e que a eternidade não pode ser definida pelo tempo, nem ter, com este, qualquer relação. Apesar disso, sentimos $e$ experimentamos que somos eternos. Com efeito, a mente não sente menos aquelas coisas que ela concebe pela compreensão do que as que ela tem na memória. Pois, os olhos da mente, com os quais ela vê e observa as coisas são as próprias demonstrações (grifo nosso).
\end{abstract}

Pelo escólio, compreendemos que, se a mente humana não pode ser destruída inteiramente com o corpo, isto não significa que ela tenha existido antes dele, nem depois, uma vez que a eternidade não pode ser definida pelo tempo, ou seja, não cabe atribuir a ela a sequência temporal (antes e depois). A eternidade não é sinônimo de imortalidade. Não é um “além” que nos aguardaria fora do mundo, ou em outro mundo. De acordo com Moreau, "na linguagem de Espinosa, 'eternidade' e 'duração' não designam universos entre os quais se repartiriam os seres (não podemos considerá-las como representado uma espécie de versão espinosista do 'au-delà' e do 'ici-bas')”246 . A mente sente que é eterna ou experimenta a sua eternidade não pelo sentimento das coisas que ela tem na memória, mas pelo sentimento das que “ela concebe pela compreensão”, de acordo com os seus “olhos” (as demonstrações). Trata-se de um conhecimento afetivo que é uma atividade cognitiva (intelectual), que, desde a proposição E V, P1, é destacado. Esse conhecimento, para Espinosa, é intuitivo, o que não significa um conhecimento fora da experiência. Com ele, conhecemos essências singulares e, quanto mais as conhecemos, mais compreendemos a Deus (E V, P24). Ele "procede da

246 Moreau, P.-F., Spinoza: l'expérience et 'éternité', p. 505. Para Moreau, a alma, a cada vez que opera com uma demonstração, ela compreende a necessidade, a qual se destaca sobre o fundo do que não é necessário (do nosso conhecimento ordinário e imaginário), de sorte que ela percebe a diferença entre ambos. Assim, segundo esse comentador de Espinosa, "é a existência da finitude que permite que a necessidade seja objeto não somente de conhecimento adequado, mas também de sentimento”, ou ainda “O sentimento da finitude é a condição do sentimento da eternidade e, mesmo, em um sentido, ele é o sentimento da eternidade”. Essa interpretação, por sua vez, foi criticada por Chantal Jaquet, para quem "não é através da finitude, mas através da certeza que sentimos e experimentamos que somos eternos”. Não nos cabe aqui aprofundar esse debate, apenas o apontamos para que o leitor saiba que se trata tanto de um tema complexo quanto controverso. A esse respeito, conferir o livr o de Moreau, aqui citado (sobretudo as páginas 543 e 544), e o livro de Jaquet, Sub specie aeternitatis:étude des concepts de temps, durée et éternité chez Spinoza. Paris, Éditions Kimé, 1997; pp. 102-3. 
idéia adequada de certos atributos de Deus para o conhecimento adequado da essência das coisas” (E V, P25demons.). Ora, vimos que as essências singulares não são nunca algo simples (e que o simples é uma abstração), mas complexo. Conhecendo essências singulares conhecemos o absoluto (que também é complexo) e conhecemos nossa união com ele (com a Natureza inteira ou com Deus). E, se esse conhecimento segue "da idéia adequada de certos atributos de Deus para o conhecimento adequado da essência das coisas”, isto significa que as essências (complexas) são articuladas por relações de causalidade imanente. A dedução (explicação) das essências é conhecimento da causalidade imanente (conhecimento da articulação dessas essências em relação à sua origem necessária), e por isso não há oposição entre dedução e intuição, uma vez que a primeira explicita os nexos de imanência que definem uma essência - a sua conexão necessária e não a sua concatenação imaginária, pois, neste caso, não se trata de deduzir, mas de pressupor/envolver, como vimos anteriormente. De toda maneira, é importante assinalar que, quer seja na imaginação, quer na intuição, estamos sempre na experiência. Esses dois gêneros de conhecimento são, nas palavras de Chaui, as duas pontas da experiência (com um, conhecemos existências e, com outro, essências).

No texto “Spinoza: uma ontologia da relação?”, Vittorio Morfino considera o conhecimento sub specie aeternitates como o conhecimento de relações, uma vez que a substância "não é senão a estrutura permanente” de reenvio de um modo a outro, e de nenhuma maneira "um tipo de substrato permanente em que as modificações são colocadas”. Assim, a eternidade é entendida como a estrutura das durações. Ou seja, tomando as durações em termos relacionais, a eternidade seria imanente ao entrelaçamento das durações - não teria nem quando, nem antes, nem depois, ou seja, não seria um instante único que condensaria todos os tempos. Também parece ser esta a concepção de Balibar ao dizer que a substância não precede os indivíduos, que ela não é um Ser global do qual tudo seria deduzido, e sim a multiplicidade de indivíduos. Ela, a substância, designa identicamente o processo infinito de produção de indivíduos e a infinidade de conexões causais existente entre eles ${ }^{247}$.

Assim, a substância não poderia ser vista como um substrato ou suporte para acidentes, nem a eternidade como um suporte atemporal para o temporal. Nela [na substância eterna] vivemos, nos movemos e temos nossa existência. Conhecê-la é conhecer a nós (singularidades), apreender aquilo de que somos feitos (relações). A única consequência que disto pode decorrer é a nossa liberdade e a nossa felicidade - a alegria que acompanha o conhecimento adequado, que não pertence mais ao domínio das paixões, sem fugir do campo afetivo.

Para Balibar, a eternidade é “uma qualidade dessa parte de nossa existência atual que é ativa

247 BALIBAR, E. "Individualité et transindividualité chez Spinoza”. 
ou na qual somos a causa adequada de nossa preservação. Já que somos 'eternos', nesse sentido, nosso poder de atuar e existir e nosso poder de pensar e entender são uma e a mesma coisa”248. A liberdade é a aptidão do corpo e da mente para a pluralidade simultânea - de afecções, afetos e idéias. Nela, o conatus é a causa eficiente imanente e adequada - total - de nossas ações e pensamentos. Assim, a proposição que define a liberdade espinosana é a que mencionamos, no corpo do nosso texto, sem citá-la, o que cabe fazer agora: “Quem tem um corpo capaz de muitas coisas tem uma mente cuja maior parte é eterna” (E V, P39). E, para finalizar, fazemos nossas as palavras de Chaui: “Liberdade, pois, não é ausência de causa, mas presença de uma causa necessária interna que exprime a essência do ser que a efetua. A necessidade é causa eficiente interna; a liberdade, autodeterminação" 249 . Isto posto, podemos supor que uma das passagens anotadas por Bergson, na leitura do livro de seu amigo Jankélévitch, como ele dissera ter feito porque sempre se surpreende ao ler a Ética (e ver que a maior parte de suas teses são o oposto do espinosismo), na carta com a qual abrimos este capítulo, começa com a definição de liberdade na filosofia bergsoniana e termina comparando-a com a de Espinosa (colocado ao lado de Platão e dos estóicos), a saber: “A liberdade se desprende do passado total; ela exprime uma espécie de necessidade superior - a determinação do moi pelo moi; pois é o mesmo que aqui é, ao mesmo tempo, causa e efeito, forma e matéria [...]. A liberdade assim concebida será como Platão, os estóicos e Espinosa a compreenderam, uma necessidade orgânica que se opõe, ao mesmo tempo, à indiferença e ao determinismo”, 250 .

248 Balibar, E. "De la individualidad a la transindividualidad” tradução de Anselmo Torres. Córdoba: Encuentro Grupo Editor, 2009; p. 69.

249 Chaui, M., op. cit., p. 81.

250Jankélévitch, V. Henri Bergson. Paris: PUF, 1959, p. 79. 


\section{Considerações finais}

“À primeira vista, a idéia de analisar a interpretação de Espinosa por Bergson revela um projeto ou uma brincadeira de mau gosto, tendo em vista o quanto é evidente que houve em Bergson uma hostilidade de princípio às construções metafísicas tais como as da Ética” ${ }^{251}$. Com estas palavras, Pierre Trotignon abre sua comunicação, cujo título é, justamente, “Bergson et Spinoza”, apresentada num ciclo de jornadas consagradas ao tema Spinoza au XX siècle (mesmo título da coletânea de textos publicada posteriormente), que tiveram lugar na Universidade de Paris I, em 1991. Autor de uma obra importante para os estudiosos de Bergson, Trotignon, na sequência do texto mencionado, considera que: “É por isso, aliás, que Martial Guéroult, em seu artigo 'Bergson en face des philosophes' [...] tratava Bergson como um mau estudante, que não teria compreendido nada do método sadio da história da filosofia, e não faria nenhum esforço para compreender o pensamento de um autor segundo seu modelo original”. Para não incorrer em crítica tão severa, o estudioso da obra bergsoniana considera que é preciso supor que Bergson tinha razões para descartar o espinosismo. São estas razões que o autor expõe nesse curto texto (cerca de oito páginas) sobre o que uniria e o que separa ambos os filósofos. Para tanto, ele menciona, é claro, as palavras de Bergson sobre Espinosa, escritas em contextos distintos para correspondentes diferentes, e desnorteantes para os que conhecem a obra e as críticas do primeiro a respeito do segundo (as quais tivemos ocasião de citar em outros momentos desta tese): a que afirma que "todo filósofo tem duas filosofia, a sua e a de Espinosa”, e a que expõe a surpresa de Bergson porque, ao ler a Ética, sente-se um pouco em si mesmo, ao mesmo tempo em que "as [suas] teses parecem ser, e são efetivamente em [seu] pensamento, o oposto do espinosismo”. Assim, pretendendo explicar a hostilidade do filósofo francês pela construção metafisica da Ética e, ao mesmo tempo, a sua admiração pelas teses dessa obra, sem cair na severidade da crítica gueroultiana, Trotignon sublinhará que, para Bergson, “a atitude de Espinosa e a atmosfera de seu pensamento são, mesmo tendo dado uma forma geométrica a ele, um retorno à atitude puramente prática e um ar de liberdade, para além da recaída que sempre ameaça encerrar o espírito” ${ }^{252}$. Isto revelaria também a visão bergsoniana da história da filosofia como um conflito permanente, interno a toda filosofia, entre a necessidade de expressão por conceitos e o elã psíquico originário do movimento da duração no universo e na consciência. Espinosa, apesar da rigidez sistemática e geométrica, teria invertido o

251 Trotignon, P. “Bergson et Spinoza” in Spinoza au XXème siècle. Paris: PUF, 1993, p. 3. 
acobertamento da intuição pela inteligência abstrata em sua concepção de sabedoria. Mas, para além da admiração, está a separação entre ambos, e tal seria oriunda do contraste entre suas ontologias, pois enquanto, “em Espinosa, nós sentimos e experimentamos que somos imortais [sic], Bergson põe uma determinação temporal do ser que é tal que a morte se torna o enigma no qual se joga, para o indivíduo, o sentido de sua interpretação do sentido do ser”253. Mesmo substituindo "eternidade” por “imortalidade” (lapso?), Trotignon afirmará a “diferença entre uma ontologia do ser eterno e uma ontologia do ser imortal”, sendo a de Bergson a que considera o esforço de viver como uma preparação para a imortalidade, porque o movimento do indivíduo, na duração melódica de sua vida, implica uma imortalidade desse mesmo indivíduo, enquanto, a de Espinosa seria caracterizada pela identidade da realidade e do ser, da qual resulta que "a eternidade contém a substância de uma alma modal”, o que, como sabemos, por tudo o que apresentamos da tradição crítica, significa que não há individualidade da alma. Assim, para finalizar a apresentação desse texto e refletirmos um pouco sobre o que vislumbamos fazer neste trabalho, falta mencionar que, após o que foi exposto, Trotignon afirma um "único ponto comum dessas duas ontologias”, qual seja, a "denúncia do nada como ilusão verbal”, para, logo em seguida, relativizar ou restringir as possibilidades dessa comunhão, pois, no seu entender, "no caso de Espinosa, o 'nada' é rejeitado como contradição lógica, porque um não-ser não poderia possuir propriedades, enquanto, em Bergson, o nada é uma idéia falsa criada pela metafísica e pela ontologia intelectualista, a qual reaparece em Espinosa”254.

As razões de Bergson para se opor ao espinosismo devem, portanto, ser suficientemente consideradas para não nos apressarmos em considerar que ele é conduzido, desde o início, a “rejeitar ao nada o conjunto da tradição filosófica”, como afirmado por Guéroult no artigo supracitado ${ }^{255}$. A esse respeito, pomo-nos de acordo com Trotignon, mas pensamos que, mesmo lançando uma isca aos incomodados com a severidade dessa leitura, que é quase sumidade no que concerne à postura de Bergson em face dos filósofos, ele acaba confirmando que falar dos dois autores é algo sem pertinência, ainda que, à primeira vista, a idéia exposta no início de sua comunicação parecesse brincar com tal interdição. Isto porque as razões para a oposição permanecem no âmbito do que os diferiria na visão bergsoniana, reiterando a crítica (o intelectualismo e o geometrismo que sempre ameaçam o espírito), mas buscando uma atitude ou intuição como fonte pulsante no sistema do filósofo holandês. Ainda que ele aponte um caminho, não o desenvolve, pois, não fazendo dialogar a crítica com o que dela surge, ou seja, não considerando o confronto com a posição e a reposição dos

252 Ibidem, p. 5.

253 Ibidem, p. 10.

254 Ibidem, p. 10. 
termos ou do processo que é a própria reflexão, novamente vemos Bergson “em face de” um filósofo, numa oposição tão externa quanto estéril - a hostilidade justifica a rejeição, e não, como pensamos, aponta um campo de interlocução, revelando um pensamento em constante reelaboração. Nesse sentido, ele acaba reiterando a compreensão de Guéroul, para o qual Bergson abordaria a história da filosofia de duas maneiras, ou sob duas concepções: uma, como filósofo, opondo a sua filosofia a todas as que the são precedentes, como a verdade é oposta ao erro; outra, como historiador, percebendo "em todas as doutrinas uma substância filosófica vivente, que as torna irrefutáveis em si mesmas”, devido à intuição que as anima ${ }^{256}$. Ele reitera tal compreensão não porque a repita, posto que, na visão de Guéroult, mesmo quando Bergson valoriza a intuição, mostrando que não há filosofia sem ela e elevando todas as doutrinas à “qualidade de objetos dignos de história”, ele, paradoxalmente, retira "consequências metodológicas que vão ao encontro da primeira” concepção, ou seja, de uma “metodologia simplificante”. Para exemplificá-la, Guéroult faz valer o caso de Espinosa, cuja grandiosidade como filósofo está em que "ele compôs a Ética ao invés de permanecer mergulhado em uma vaga intuição panteística” ${ }^{257}$. Dito de outro modo, essa metologia é simplificante, porque "os conceitos essenciais, que são os mais numerosos, constituirão não meios de expressão, mas elementos orgânicos, as próprias articulações da solução que o filósofo descobriu por si mesmo”258. Assim sendo, a construção espinosana não pode ser separada da intuição que a anima. Disto não discordamos, mas será que Guéroult, para salvar os filósofos da crítica bergsoniana, não inverteria os papéis, também numa metodologia simplificante, porque, ao final, a sua conclusão é a de que, em qualquer das concepções, Bergson partiria de uma “doutrina pronta”, a sua, única capaz de atingir o absoluto? Ao invés de considerar todas as doutrinas como vistas estáticas tomadas da história da filosofia (concepção bergsoniana, em seu entender), ele não faria da filosofia de Bergson uma concepção que mereceria ser, ela sim, vista como uma doutrina $a$ priori e enrijecida em sua verdade? Ora, para expor a concepção bergsoniana da história da filosofia, Guéroult sintetiza o “coup d'oeil” que Bergson lança à história dos sistemas filosóficos no quarto capítulo de A Evolução criadora, mostrando como a história da filosofia se apresenta, para o filósofo da duração, ao ritmo da história da ciência, não sendo mais que um epifenômeno dela ${ }^{259}$. Mas, seria suficiente compreender a abordagem bergsoniana da história da filosofia apenas pela história dos sistemas do último capítulo d'A Evolução? Ela não teria, no contexto desse livro, um

255 Guéroult, M., “Bergson en face des philosophes” in Les études bergsoniennes. Paris: PUF, 1959; p. 11.

256 Ibidem, p. 32.

257 Ibidem, p. 28.

258 Ibidem, p. 30.

259 Ibidem, pp. 13-23. 
papel a desempenhar devido aos interesses dessa obra, constituindo uma das dimensões da crítica bergsoniana às doutrinas filosóficas? E, ainda que essa dimensão, pela crítica genética, desvele o erro sistemático, do qual foram vítimas todos os sistemas filosóficos (como vimos no segundo capítulo desta tese), isto significaria “rejeitar ao nada o conjunto da tradição filosófica”? Pensamos que a crítica genética de $A$ Evolução criadora, responsável pela visão da história dos sistemas (apresentada nessa mesma obra) como repetição de um erro, não fecha o debate com a história da filosofia (ou com a doutrina espinosista, em nossa compreensão), uma vez que, por exemplo, artigos posteriores retomarão a temática do paralelismo (que se torna o grande adversário para pensar a relação entre corpo e alma, e que aparece como uma questão encerrada na história dos sistema dessa obra), recolocando-o sob o ponto de vista histórico e o sob o empírico, como a conferência, de 1912, sobre “A alma e o corpo” e o "Segundo prefácio” (1911) de Matéria e memória.

O que vislumbramos mostrar pelas distintas dimensões críticas, apresentadas no primeiro e no segundo capítulos, no que concerne ao caso específico do paralelismo (fundamental porque é a outra face do problema da liberdade) e do Ser espinosista (fundamental porque é empecilho para que a duração seja apreendida), é que a interlocução com o espinosismo ganha uma relevância que pode ser observada em diferentes obras, de modo que, neste diálogo crítico (que certamente não é o único da obra, e sim aquele a que nos dedicamos), Bergson põe e repõe tanto as suas críticas quanto os resultados das mesmas, como, por exemplo: a idéia de uma circularidade entre ciência e metafísica, a qual não é explicitada com todas as letras na primeira obra do filósofo (mesmo que esteja presente, nela, a influência da noção de grandeza intensiva kantiana na psicofisiologia nascente); a passagem do kantismo ao espinosismo como origem do associacionismo, no curso sobre a história das teorias da memória, que, de certa maneira, está presente no “Segundo prefácio” de Matéria e memória (texto que deveria, dali em diante, ser incluído na obra publicada), o qual também identifica paralelismo e epifenomenismo, de modo a fazer valer para ambos o que, antes, valia para um deles; a mudança de interlocução no que diz respeito ao "problema da liberdade” (dos deterministas e do criticismo para o paralelismo e a lógica espinosista); a necessidade, portanto, de um embate com o espinosismo, como exigência à reinstauração da metafísica. Assim, pensamos que, mais do que invalidar as doutrinas filosóficas ou sublinhar a intuição nelas presente (difusa, já que não seria a verdadeira intuição ou, nas palavras de Guéroult sobre Bergson, seria uma intuição psicológica e não metafísica, como só a bergsoniana o é), o estudo das doutrinas do passado permite ao filósofo realizar um salto na intuição, seu próprio salto, o que não é uma supressão das mediações, mas a sua radicalização - é, portanto, elemento intrínseco e constituivo de seu método e, consequentemente, de sua filosofia (lembrando que a intuição é o método bergsoniano para a apreensão da duração). 
Filosofia que se consolida ou se faz com a crítica aos sistemas metafísicos. Se houve ruptura e recusa de toda herança, também houve diálogo, assimilação e (re)elaboração ${ }^{260}$. Afinal, os momentos de fracasso da filosofia apresentados na história dos sistemas (como mostramos no segundo capítulo deste trabalho) não foram também momentos em que algo novo foi vislumbrado? E não foram os novos elementos (dos momentos desperdiçados) assimilados por Bergson em seu impulso inicial e constante? A evolução spenceriana o faz despertar para a questão do tempo (como afirmado em $O$ pensamento e o movente, anos depois de A Evolução criadora), o criticismo kantiano mostrara as armadilhas a que a metafísica tradicional era levada e o cartesianismo, mantendo a unidade de conhecimento, num momento em que a ciência se transformava sobremaneira, evidenciara a necessidade da distinção de métodos e objetos entre ciência e metafísica, por exemplo. Destarte, podemos ver na crítica aos diversos sistemas filosóficos, e em diferentes momentos de sua obra, linhas de fatos que convergem para o mesmo centro: a afirmação da duração. Ela faz parte do esforço do filósofo de pensar e apresentar a sua própria filosofia: é parte de seu pensamento em vias de se fazer. Pensamos que historiador e filósofo, neste caso, não se separam. A crítica bergsoniana dos sistemas filosóficos e a consolidação da sua filosofia acontecem ao mesmo tempo. Trata-se de um pensamento que se define justamente pelo se faisant, e isto com as doutrinas que "rejeita”, ou melhor, com as doutrinas com as quais se confronta.

Iniciamos nosso trabalho quando nos deparamos, ao mesmo tempo, com algumas das críticas de Bergson a Espinosa e com elementos que nos permitiam “aproximá-los”. Assim sendo, intentamos descobrir o que encontraríamos num entrecruzamento de seus pensamentos. Num primeiro momento, vimos a necessidade de um mapeamento da crítica, por ser ela o que ressaltava na leitura dos textos. Ao reconstitui-la, pudemos perceber tanto a sua abrangência, em Bergson, quanto a sua inserção numa tradição de leitura. No que diz respeito a essa tradição, não havia nenhuma novidade efetiva (não era uma crítica nova). Esta estaria presente, não obstante, pela maneira como a crítica trabalhava na obra de Bergson, pela ressonância em seu interior. Primeiramente, perguntávamos por que Bergson não deu mais importância aos "impulsos de originalidade” da intuição espinosana, e repondíamos: porque, entre ambos, havia o espinosismo. Posteriormente, vimos que era preciso levar em conta que, se Bergson não desenvolveu a leitura da "intuição espinosana”, não se tratava de

260 Tomamos alguns desses termos das palavras de Gouhier, a seguir citadas, sem pensá-las numa oposição em que seria inconcebível a "assimilação" e a "ruptura", por exemplo. Lemos na "Note sur le progrès et la philosophie" que: "Vontade de assimilação ou de ruptura, sentimento de uma certa continuidade ou de uma radical descontinuidade, busca de predecessores ou recusa de toda herança, há, em toda filosofia, um horizonte histórico e, quando fala a 'visão do mundo' de um filósofo, convém buscar qual é o mundo de sua cultura filosófica” (Henri Gouhier, "Note sur le progrès et la philosophie" in Études sur l'histoire de la philosophie en hommage a Martial Guéroult, p. 113). 
uma falha, nem de um acidente de percurso. A questão mais importante era a do papel da crítica ao espinosismo na filosofia bergsoniana. O que ele identificou como teses espinosistas permitiu suas críticas, conduzindo-o à (re)afirmação do que elas negavam - a duração, a experiência vivida e a liberdade. Assim, não se trata de dizer que a leitura foi correta ou incorreta no que concerte à filosofia espinosana, mas de pensar o lugar e a amplitude da crítica ao espinosismo na obra bergsoniana. E foi, então, com o diálogo crítico, que pudemos encontrar o que, sob perspectivas diferentes (filosóficas e históricas), os unia. Melhor dizendo, é no confronto com o espinosismo que Bergson se encontra com Espinosa, ou que alguns de seus temas revelam buscas e preocupações passíveis de comunhão. Por isso, ao circunscrevermos a leitura que possibilitava a crítica (a tradição em suas múltiplas facetas), fomos ao encontro da contradição (leia-se contra-dicção, ou contra o discurso instituído da tradição) entre a doutrina espinosista e a filosofia espinosana, pela releitura que expusemos em nosso último capítulo. Dentre aquilo que o confronto mostrava, destacamos como possibilidades de encontro (que não explicitamos no percurso realizado porque acreditávamos que a sua leitura o revelava, de alguma maneira, sem a necessidade de constantes reenvios): a distinção dos domínios do conhecimento, separando a ausência da presença, cuja consequência era a distinção como método contra-ideológico (em Bergson, no que diz respeito à circularidade entre ciência e filosofia, e, em Espinosa, à confusão entre teologia e filosofia); a novidade quanto à maneira de pensar a relação entre corpo e alma (nem dualismo à la Descartes, nem paralelismo, nem epifenomenismo); a liberdade como expressão do que somos (existência sob o modo da autenticidade) que nada tem a ver com o livre-arbítrio (seja o dos adverários do determinismo, seja o que se inscreve no plano teológico); a subversão dos conceitos da tradição, de maneira a ganharem outra força (re)significante (tais como o de substância e o de eternidade, com suas distinções numa e noutra filosofia); o abosoluto como aquilo de que não somos apenas parte, mas do qual participamos (experimentando em nós a criação ou expressando-o como causa adequada de nossas ações e pensamentos); a intuição (que é método, num, e gênero de conhecimento, noutro) como o que nos faz conhecer singularidades (vividas ou complexas), revelando-nos a realidade; a eternidade como algo vivo, ou seja, que nada tem a ver (em ambos) com a gelidez de morte da concepção conceitual e lógica do espinosismo; a alegria que acompanha o conhecimento (raro ou difícil) do que somos nós (viventes humanos ou modos finitos).

Frente a tamanha possibilidade de diálogo, novamente cabe questionar as razões de sua rejeição no que concerne aos leitores que nos são contemporâneos. Certamente elas dizem respeito à evidente hostilidade de Bergson à construção espinosista, ou seja, ao fato de permanecerem cativos da crítica bergsoniana, o que significa: identificar Espinosa com o espinosismo, não questionar a 
tradição que sustenta tal leitura e não procurar o papel dessa crítica na obra do filósofo francês, e isto porque seria algo já dado ou consumado pela maneira como ela (a crítica) é feita, sobretudo na história dos sistemas de A Evolução criadora, tanto concisa quanto definitiva. Algumas tentativas de aproximação, com as quais nos deparamos, acabavam deslizando para uma abordagem distorcedora, principalmente no que concerne à filosofia de Espinosa, exposta com os termos da tradição. Uma dessas tentativas ${ }^{261}$, por exemplo, é o texto de François D'Hautefeuille, “Bergson et Spinoza”, que nos parece emblemático a esse respeito. Nele, são apresentadas, em princípio, “as profundas oposições” entre os dois filósofos, das quais podemos citar: o intelectualismo de Espinosa em oposição à recusa de Bergson de que a inteligência seja apta ao conhecimento puro; o geometrismo de Espinosa, que nega o tempo (torna-o inoperante) e faz com que tudo derive da eternidade imóvel, em oposição à duração como substância das coisas; o determinismo de Espinosa, que regula, com uma rigorosa correspondência, o desenrolar dos atributos diversos (paralelismo: “tese a propósito da qual o conflito de nossos dois filósofos é absolutamente inegável”) em oposição ao protesto de Bergson contra a equivalência do cerebral e do mental ${ }^{262}$. Feitas estas ressalvas incontestáveis, na perspectiva desse comentador, “encontra-se, sem esforço, matéria para muitas aproximações curiosas”, quais sejam: a liberdade (definida pela relação do ato com nosso ser verdadeiro); a crítica à idéia de possível; a aparição do mundo como expressão da natureza divina; a crítica ao finalismo; o fato de serem filosofias da afirmação; e, enfim, a abordagem de ambos quanto à nossa situação no absoluto ou nossa relação com Deus. O curioso é que o encontro dessas aproximações não o faz reconsiderar a crítica ou os termos da oposição, os quais por si mesmos (pensando em suas consequências, como vimos na exposição das críticas de Bergson ao espinosismo) negam, ao menos em parte, o que poderia permiti-las (a liberdade, por exemplo). Mantendo tais termos opositores, não é estranho que o texto seja finalizado com uma última e conclusiva oposição entre, por um lado, a beatitude de Espinosa, caracterizada pelo "repouso" ou “parada”, de maneira que "não era, sem dúvida, a que convinha a Bergson”, e, por outro, a eternidade em Espinosa, essa “eternidade gélida, que paira desdenhosa acima da duração”, e a eternidade, como a pensava Bergson, "um triunfo de infindável alegria”263. Assim, se as “aproximações curiosas” não são incorretas do ponto de vista do que afirmam, elas perdem qualquer

261 Outras, mencionadas em nosso trabalho, são: o texto de Trotignon, com o qual abrimos estas considerações finais, e o texto de Axel Cherniavsky, “'Vieja, muy vieja mercadería'. Spinoza y Bergson”, que citamos e comentamos na nota 249 deste trabalho.

262 D'HAUTEFEUILLE, F. "Bergson et Spinoza” in Revue de métaphysique et de morale, t. LXV, nº 4, octobredécembre, 1960, pp. 463-474. A citação sobre o paralelismo encontra-se na página 468.

263 Ibidem, p. 474. 
sentido frente ao que os separa, já que Espinosa é visto pelas lentes distorcedoras que tanto já assinalamos.

Pensamos que se, entre Bergson e Espinosa, há um fecundo diálogo, este não pode ser feito (ou refeito) pela busca de similitudes como pontos de contato isolados do movimento que constituem seus pensamentos. Mais ainda: pensamos que também é preciso certo posicionamento no debate, não aceitando o dado e imediato, e buscando o que anima as leituras (as mediações), de maneira a também assumir uma leitura. Nesse sentido, discordamos de outro autor que procurou uma aproximação entre ambos, desta vez buscando "Les thèmes spinozistes dans la philosophie de Bergson”, a saber, Sylvain Zac. Este autor, o mesmo que nos ajudara a esclarecer a "querela do panteísmo”, não permanece, digamos, na superfície das críticas bergsonianas, ao contrário, aponta que elas "são lugares comuns que circulam nas obras de alguns comentadores de Espinosa e que Bergson retoma” ${ }^{264}$. Como o seu objetivo não é o lugar que ocupam na obra bergsoniana, feito tal apontamento, ou outras breves ressalvas ao longo do texto, ele se ocupa daquilo que compõe a sua problemática, explicitando, contudo, que se trata de procurar “os temas espinosistas na filosofia de Bergson, sem tentar negar a originalidade de sua filosofia” ${ }^{265}$. Tentativa complicada pela intenção explícita do texto, ou seja, pela busca de temas que são, digamos, a priori espinosanos. Mas, mesmo tomando a ressalva seriamente, e considerando que a originalidade da filosofia bergsoniana não é negada, não nos colocamos de acordo com o autor. Isto porque a relação que vai se explicitando nos temas abordados leva para uma comunhão de interesses que consideramos, sob nossa perspectiva, a menos interessante, porque ancorada, em grande parte, em uma leitura da filosofia de Espinosa como uma "'verdadeira religião, suscetível de nos curar, pela nossa unição com um bem eterno e infinito, de nossos tormentos e paixões, e de nos propiciar a maior alegria possível”266. Assim, ao tratar do tema da liberdade, o autor afirma que, “em Espinosa, a liberdade tem uma ressonância religiosa, e, no tema da saúde pela alegria e pelo amor, lemos que é "também o tema da alegria e do amor que anima as idéias morais e religiosas de Bergson”, de maneira que, como poderíamos esperar, o autor compara “o Sábio espinosista [que] sabia que, apesar de sua diversidade, elas [as essências de todos os outros homens], estão todas unidas em Deus e por Deus” e o “santo bergsoniano [que] se sente

264 ZAC, S. “Les thèmes spinozistes dans la philosophie de Bergson” in Les études bergsoniennes, t. VIII. Paris: PUF, 1968, p. 131.

265 Ibidem, p. 127.

266 Comentário que aparece no iníco do texto, antes de sua divisão nos temas que serão abordados, quais sejam (de acordo com a própria divisão e enumeração do autor): a) Tema da anterioridade da ontologia em relação à teoria do conhecimento; b) Tema do dinamismo do Ser; c) Tema da distinção do tempo e da duração; d) Tema da plenitude ontológica e da rejeição da concepção mosaica da criação; e) Tema da liberdade enquanto expressão autêntica de nosso ser; f) Tema da saúde pela alegria e pelo amor; g) Tema do Cristo. Apesar de nossas ressalvas quanto ao texto, 
impregnado por um elã de amor em direção a todo homem, porque ele sente o parentesco de todas as almas”267. Uma das consequências desta última comparação é que: "Enfim, Bergson, como Espinosa, liga a moral e a religião" ${ }^{268}$. Claro está que a referência maior para tais relações são As duas fontes da moral e da religão, de Bergson. E, o curioso é que o autor parece, de certa maneira, refletir, em Espinosa, tais temas bergsonianos. Ou, o que pode ser mais exato, encontra em Bergson a leitura da moral e da religião que melhor expressa Espinosa. Esta não é a nossa leitura. E porque não lemos a beatitude espinosana como uma cura que nos faria inatingíveis pelas paixões (já que somos essencialmente passionais), nem vemos o "sábio espinosista" como um santo impregnado de amor, não pensamos que se trata de uma moral (mas de uma ética) ${ }^{269}$, nem lemos, em Espinosa, a afirmação de uma "verdadeira religião", não fizemos de As duas fontes da moral e da religião a maior referência de nosso trabalho. O nosso intuito, conforme assinalamos, foi o de buscar o entrecruzamento a partir das críticas de Bergson a Espinosa ${ }^{270}$, fazendo delas o motivo do diálogo (confronto e encontro). Portanto, não se trata, aqui, nem de encontros pontuais (casuais), nem de encontrar em um o que é de outro, mas de buscar o que há entre ambos, como campo que permite também, pensamos, ampliar o diálogo de maneira a fazer reverberar outros encontros. Expliquemos.

No texto, “Sobre a metafísica do tempo de Bergson”, Max Horkheimer faz uma leitura da obra desse filósofo segundo a qual ele teria “de forma brilhante” demonstrado a relação dos conceitos fundamentais da filosofia (idéia e substância, por exemplo) com a atividade produtiva, explicitando a absolutização dessas categorias, mas o teria feito ao mesmo tempo em que erigia um "novo mito metafísico", afirmando que o "nosso fluxo de vivências, que captamos por meio de um mergulho 'intuitivo' no próprio interior, seria idêntico à vida espiritual criadora que perpassa a totalidade do mundo” ${ }^{271}$. Para ele, o filósofo da duração nega o tempo quando faz dele um princípio metafísico. Ele acoberta o tempo vivido dos homens, o qual é limitação, negação, sofrimento e

consideramos que ele é um estudo interessante e com muitas contribuições para os interessados nesse diálogo.

267 ZAC, S. "Les thèmes spinozistes dans la philosophie de Bergson” in Les études bergsoniennes, t. VIII. Paris: PUF, 1968, p. 152.

268 Ibidem, p. 153.

269 Como exemplo de uma leitura com a qual nos pomos de acordo sobre esse tema, conferir o segundo capítulo do livro de Gilles Deleuze, Espinosa: filosofia prática, cujo título é:“Sobre a diferença da Ética com uma moral”.

270 Assim, mesmo que no primeiro capítulo de As duas fontes da moral e da religião, Bergson cite, para mudar seu sentido, expressões espinosanas (Natureza naturante e Natureza naturada), tal não se coloca no campo do confronto tal como analisamos. Lemos que: "Poderíamos dizer, distorcendo de seu sentido as expressões espinosistas, que é para voltar à Natureza naturante que nos desligamos da Natureza naturada” (cf. As duas fontes da moral e da religião, p. 56). Se Bergson utiliza tais expressões, dando-lhes o devido crédito, é para, mudando o sentido que têm em Espinosa, descrever a passagem da sociedade fechada à sociedade aberta, ou da religião estática à dinâmica, sem uma crítica explícita, como as que apontamos.

271 Horkheimer, M., “Sobre a metafísica do tempo de Bergson” in Cadernos de Filosofia Alemã 6, p. 61-83, 2000; p. 67. 
morte (o tempo "real”, para Horkheirmer) a partir do desenvolvimento da durée como essência única e eterna da totalidade do mundo, destinando "os homens que sofrem sob condições reais à comunhão com aquela essência, isto é, à elevação espiritual. Como os metafísicos precedentes, Bergson transfigura o existente, até mesmo afirma sua divindade”. Assim, como todo bom metafísico, ele não consideraria as condições históricas, pois delas não partira (partiu da natureza) ou as consideraria como um fator menor, uma vez que seriam alcançadas pelo entendimento, quando a verdadeira realidade só pode ser alcançada pela intuição. O problema de Horkheimer está em Bergson ter substancializado o tempo, assim como o problema maior de Espinosa, para Bergson, está em sua concepção de substância, que seria um conceito sem relação com a experiência, e cuja eternidade seria também, de certa maneira, um consolo num mundo de desconsolo, ou melhor, é um desconsolo (um princípio surdo para as preces dos que sofrem neste mundo) - o que é comum a todas as metafísicas, sobretudo modernas, mas que, como vimos, fora hipostasiado na substância eterna espinosista. Em nenhum dos casos se trata de consolar os homens com a possibilidade da vida eterna. E, em ambos os casos, o que é mais interessante e admirável, é o esforço de conhecimento nas condições históricas vividas e contra certas práticas de poder dominantes, de modo que se trata de uma definição completamente nova de substância (nos dois filósofos) e, por isso, ela é tão difícil de ser compreendida. Cremos que aqui está a chave para a leitura equivocada que se fez de Espinosa, que Bergson reiterou, e para a leitura que mantém Bergson à margem das reflexões sobre as condições histórias atuais. Nesse sentido, é também interessante de nota o silêncio a respeito do tempo bergsoniano por parte de outro autor contemporâneo, que coloca em pauta justamente a premência de uma nova concepção do tempo em relação à que domina, na cultura ocidental, há séculos, num texto intitulado “Tempo e história: crítica do instante e do contínuo”. Nele, Giorgio Agamben afirma que "toda cultura é, primeiramente, uma certa experiência do tempo, e uma nova cultura não é possível sem uma transformação desta experiência”. E, logo adiante, lemos que: “O pensamento político moderno, que concentrou a sua atenção na história, não elaborou uma concepção correspondente do tempo. Até hoje o próprio materialismo histórico furtou-se assim a elaborar uma concepção do tempo à altura de sua concepção histórica. Em virtude dessa omissão, ele foi inconscientemente forçado a recorrer a uma concepção do tempo que domina há séculos a cultura ocidental, e a fazer então conviver, lado a lado, em seu próprio âmago, uma concepção revolucionária da história com uma experiência tradicional do tempo” ${ }^{272}$. Para ele, a concepção ocidental do tempo é prisioneira de uma idéia de acumulação ou sequência de instantes pontuais, que

272 Agamben, G., “Tempo e história: crítica do instante e do contínuo” in Infância e história: destruição da 
impede conceber a vivência da historicidade, desconsiderando Bergson como pensador de uma noção da temporalidade capaz de refletir a indeterminação da práxis e dos acontecimentos históricos (como suspeitou Benjamin, em seu entender). Não intentamos aqui, obviamente, entrar em uma questão que mereceria muitas outras considerações e desenvolvimentos, mas apenas apontar um questonamento sobre, como afirmamos, novas possibilidades de encontro, abertas por um diálogo que não se encerra na imobilidade de similitudes pontuais. Dessa maneira, deixamos a idéia sobre uma possível volta (ou reviravolta) para o bergsonismo a partir do que recentemente (nas últimas décadas) foi feito por alguns filósofos e estudiosos (sobretudo franceses e italianos) a respeito da filosofia de Espinosa, a saber, um desvio por ela na reflexão do pensamento de Marx ${ }^{273}$. Não poderíamos também fazer um desvio pelas leituras que mostram a força do pensamento espinosano, para a compreensão da história dos homens, de maneira a buscar ainda em Bergson a força de sua originalidade, no que concerne à experiência do tempo, para pensar a história exigida pelo pensamento político moderno? No mesmo texto de Agamben, lemos que "Quer seja pensado como círculo, quer como linha, o caráter que domina toda concepção ocidental do tempo é a pontualidade. Representa-se o tempo vivido mediante um conceito metafísico-geométrico (ponto-instante inextenso) e então se procede como se este próprio conceito fosse o tempo real da experiência” ${ }^{274}$. Mas, é essa mesma crítica que encontramos em Bergson! Por que ignorá-la? Certamente porque, assim como Horkheimer (e todos os que se inscrevem, de distintas maneiras, nesse mesmo campo de reflexão) procura mostrar, a filosofia de Bergson corresponderia, no seu entender, "às solicitações de sua época sem estar, no entanto, respaldada num aprofundamento crítico do contexto histórico do qual emergem as questões que tenta reeelaborar e solucionar”, tal como expresso pelo professor Franklin Leopoldo e Silva na “Apresentação do artigo de Max Horkheimer”275. E se a crítica de Bergson ao tempo da tradição, como conceito metafísico geométrico, e à eternidade espinosista nos levou ao encontro da eternidade espinosana, não poderíamos partir desse encontro para fazer jus tanto a Espinosa, também desconsiderado pelos autores aqui citados, quando ao próprio Bergson? Nem a eternidade espinosana é uma eternidade de morte (conceitual, lógica e fora da experiência), nem a duração bergsoniana é a absolutização de uma categoria (o que significa abstração e negação do tempo “real”, sob a perspectiva acima apontada). Entre Bergson e Espinosa, vemos um diálogo

experiência e origem da história. Trad. de Henrique Burigo. Belo Horizonte: UFMG, 2008; p. 111.

273 A esse respeito, conferir a tese de Mariana de Gainza, Espinosa: uma filosofia materialista do infinito positivo, na qual a autora se vale do texto de Althusser, "Elementos de Autocrítica” em Posições I, Rio de Janeiro: GRAAL, 1978. 274 Agamben, G., "Tempo e história: crítica do instante e do contínuo" in Infância e história: destruição da experiência e origem da história. Trad. de Henrique Burigo. Belo Horizonte: UFMG, 2008; p. 122.

275 Leopoldo e Silva, F. “Apresentação ao artigo de Max Horkheimer” in Cadernos de Filosofia Alemã 6, p. 61-83, 2000; p. 51. 
fecundo sob muitos aspectos, para além da tradicional eternidade (de morte). Ora, se a "filosofia da duração" é a afirmação de um inacabamento, de uma abertura para futuros desenvolvimentos - uma filosofia que não fecha um ciclo do tempo e se põe na eternidade, mas que, imersa na temporalidade, espera (com novos diálogos, pensamentos e descobertas científicas) prosperar indefinidamente (tal como afirmado por Bergson), a interlocução entre ambos não pode ser também um ensaio dessa aspiração? 


\section{Bibliografia}

\section{Fontes primárias}

BERGSON, H. Essai sur les Donnés Immédiates de la Conscience. 144 a edição. Paris: PUF, 1970.

Matière et Mémoire. Reimpressão da $8^{\mathrm{a}}$ edição. Paris: PUF, 2008 .

L'évolution Créatrice. Reimpressão da 11 ${ }^{\mathrm{a}}$ edição. Paris: PUF, 2008.

La Pensée et le Mouvant. Reimpressão da 15ª edição. Paris: PUF, 2006.

L’Energie Spirituelle. 52 edição. Paris: PUF, 1949.

Les Deux Sources de la Morale et de la Religion. 164a edição. Paris: PUF, 1967.

Le Rire. 87 $7^{\mathrm{a}}$ edição. Paris: PUF, 1950.

Durée et simultanéité. $2^{\text {a }}$ edição. Paris: QUADRIGE/PUF, 1998.

Ecrits et paroles (organizado por Mossé-Bastide). Paris: PUF, 1957.

Cours I. Leçons de psychologie et de métaphysique: Clermont-Ferrand, 18871888. Paris: PUF, 1990.

Cours II. Leçons d'esthétique. Leçons de morale, psychologie et métaphysique.

Paris: PUF, 1992.

Cours III. Leçons d'histoires de la philosophie moderne. Théories de l'âme. Paris:

PUF, 1995.

Cours IV. La philosophie grecque. Paris: PUF, 1995.

ESPINOSA, B. Etica. As citações das partes I-II, são da tradução realizada pelo Grupo de estudos espinosanos da USP; das partes IV e V, são da edição traduzida por Tomaz Tadeu, Belo Horizonte, Autêntica Editora, 2007.

Pensamentos metafísicos, Tratado da correção do intelecto, Ética, Tratado político, Correspondência [cartas 2, 4, 9, 10, 12, 21, 32, 34, 35, 36, 50], seleção de textos de Marilena de Souza Chaui, traduções de Marilena de Souza Chaui, Carlos Lopes de Mattos, Joaquim de Carvalho, Joaquim Ferreira Gomes, Antônio Simões, Manuel de Castro; col. Os Pensadores, São Paulo, Abril Cultural, 1979.

Éthique, trad. : B. Pautrat, Éditions du Seuil, Paris, 1999.

Tractatus theologico-politicus / Traité théologique-politique, texte établi par

Fokke Akkerman, traduction et notes par Jacqueline Lagrée et Pierre-François Moreau, 
Paris, PUF, 1999.

Tratado teológico-político. Tradução, introdução e notas de Diogo Pires.

Martins Fontes, São Paulo, 2003.

Tratado da reforma da inteligência. Tradução, introdução e notas de Lívio Teixeira.

São Paulo: Martins Fontes, 2004.

Pensamentos Metafísicos. Tradução e notas de Marilena Chaui. São Paulo: Abril

Cultural, 1972 (2 a edição)

Tratado político. Tradução de Manuel de Castro. São Paulo: Abril Cultural, 1972.

\section{Outras fontes}

ALQUIE, F. Servitude et liberté selon Spinoza. Paris: Centre de Documentation Universitaire, 1966.

ARISTETELES. Metafísica. Tradução espanhola de V. G. Yebra, edição trilíngue. Madri: Gredos, 1982.

ARON, R., POLIN, R. et alii. Les études bergsoniennes II. Paris: PUF, 1956.

ARON, R. "Note sur Bergson et l'HIstoire” in Les études bergsoniennes, t. IV. Paris: PUF, 1956.

BACHELARD, G. La dialethique de la durée. Paris: PUF, 1989.

BALIBAR, E. Spinoza et la politique. Paris: PUF, 1985.

. "Spinoza: from individuality to transindividuality” (A lecture delivered in Rijnsburg

on May 15, 1993).

. Spinoza, Il transindividuale, Milano, Edizioni Ghibli, 2002.

BAYLE, P., Écrits sur Spinoza, Paris, Berg International Éditeurs, 1983.

BLOCH, O. (Org.), Spinoza au XXº siècle, Paris, PUF, 1993.

BARTHELEMY-MADAULE, M. Bergson adversaire de Kant: étude critique de la conception bergsonienne du kantisme suivi d'une bibliographie. Paris: PUF, 1966.

BOUVERESSE, R. Spinoza et Leibniz: l'idée d'animisme universel. Paris: Vrin, 1992.

BOVE, L. La stratégie du conaturs. Affirmation et résistence chez Spinoza. Paris: Vrin, 1996.

BREHIER, E., Prefácio a Adolphe, L. La Philosophie Religieuse de Bergson. Paris: PUF, 1946.

BREHIER, E., HYPPOLITE, J. et alii. Les études bergsoniennes II. Paris: PUF, 1949.

BRUNSCHVICG, L. Spinoza et ses contemporains. Paris: PUF, 1951.

Le Progrés de la Conscience dans la Philosophie Occidentale. Paris: PUF, 1953.

CHERNIAVSKY, A. “Vieja, muy vieja mercadería. Spinoza y Bergson” in Spinoza Primer Coloquio. Buenos Aires: Altamira, 2005. 
CHAUI, M. A nervura do real. São Paulo: Cia das Letras, 2003.

Política em Espinosa. São Paulo: Cia das Letras, 2003.

Da Realidade sem Mistérios ao Mistério do Mundo: Espinosa, Voltaire, Merleau-

Ponty. São Paulo; Brasiliense; 1999.

"Laços do desejo” in NOVAES, A. (org.). O desejo. São Paulo: Companhia das

Letras, 1987.

Espinosa: uma filosofia da liberdade. São Paulo: Moderna, 1995.

CHEVALIER, J. Histoire de la pensée. Paris: Flammarion: 1955.

Entretiens avec Bergson.Paris: Plon, 1959.

CRISTOFOLINI, P. Spinoza. Chemins dans l'Ethique. Paris: PUF, 1996.

DAMASIO, A. Em busca de Espinosa: prazer e dor na ciência dos sentimentos. Trad. de Laura

Teixeira Motta. São Paulo: Companhia das Letras, 2004.

DELATTRE, F., GOUTHIER, H. et alii. Les études bergsoniennes I. Paris: PUF, 1968.

DELEUZE, G. Bergsonismo. São Paulo: Editora 34, 1999.

Spinoza et le problème de l'expression. Paris: Minuit, 1968.

Spinoza. Philosophie pratique. Paris: Minuit, 1970.

Différence et répétition. $11^{\mathrm{a}}$ ed. Paris: PUF, 2003.

L'Ile Déserte. Textes et entretiens 1953-1974. Edition préparée par David

Lapoujade. Paris: Editions de Minuit, 2004.

DESCARTES, R. Règles pour la Direction de l'Esprit. Paris: Edição Alquié, Garnier, 1963.

Méditations métaphysiques. Paris: PUF, 1966.

Les Principes de la Philosophie. Paris: Edição Alquié, Garnier, 1973.

Discurso do Método - Tratado das Paixões. Trad. de J. Guinsburg e Bento Prado

Jr. São Paulo: Nova cultural, 1987 (Coleção Os Pensadores).

D'HAUTEFEUILLE, F. “Bergson et Spinoza” in Revue de méthaphisique et de morale, $\mathrm{t} . \mathrm{LXV}, \mathrm{n}^{\circ}$ 4, octobre-décembre, 1960, p. 463-474.

FRIEDMANN, G. Leibniz et Spinoza. Paris: Gallimard, 1946.

GAINZA, M. Espinosa: uma filosofia materialista do infinito positivo. Tese de doutorado defendida no Departamento de Filosofia da Universidade de São Paulo, em 2009.

"Espinosa versus Hegel. Motivos de uma confrontação" in Cadernos Espinosanos, nº 18, São Paulo, 2005.

“O tempo das partes. Temporalidade e perspectiva em Espinosa” in Cadernos

Espinosanos, nº 21, São Paulo, 2009. 
GEBHARDT, Spinoza. Buenos Aires, Editorial Losada, 1940.

GILLOUIN, R. La philosophie de M. Henri Bergson. Paris: Grasset, 1928.

GILSON, B. L'Individualité dans la Philosophie de Bergson. Paris: Vrin, 1972.

GOUHIER, H. Bergson dans l’Histoire de la Pensée Occidentale. Paris: Vrin, 1989.

GUEROULT, M. Descartes selon l'ordre des raisons. Paris: Aubier-Montaigne, 1953. Spinoza I: Dieu (?thique, 1). Paris: Aubier-Montaigne, 1968. Spinoza II: L’?me (?thique, 2). Paris: Aubier-Montaigne, 1972. “Bergson en face des philosophes” in Les études bergsoniennes, t. V. Paris: PUF, 1960.

HEGEL, G. W. F., Lecciones sobre la historia de la filosofia, v. III. México: Fondo de Cultura Económica, 1997.

HORKHEIMER, M., “Sobre a metafísica do tempo de Bergson” in Cadernos de Filsofia Alema 6. ITOKAZU, E. M. Tempo, duração e eternidade na filosofia de Espinosa. Tese de doutorado defendida no Departamento de Filosofia da Universidade de São Paulo, em 2008.

JANKELEVITH, V. Henri Bergson. Paris: PUF, 1959.

JAQUET, C.; Sevérac, P.; Suhamy, A.(orgs). La théorie spinoziste des rapports corps/esprit et ses usages actuels. Paris: Hermann Éditeurs, 2009.

JAQUET, C. Sub Specie aeternitatis. Paris, Kimé, 1993. L'unité du corps et de l'esprit. Affects, actions et passions chez Spinoza. Paris: PUF, 2004.

KANT, E. Crítica da Razão Pura. Lisboa: Fundação Calouste Gulbenkian, 1994.

KOYRE, A. Histoire de la pensée. La loi de la chute des corps. Descartes et Galilée. Paris: Hermann, 1939.

LANGE, F.-A. Histoire du matérialisme. Trad. B. Pommerol. Paris: Reinwald, 1877.

LEIBNIZ, G. Discours de Métaphysique: et correspondance avec Arnaud. Introdução, texto e comentário por Georges Le Roy. Paris: Vrin, 1984.

La Monadologie. Edição crítica de Emile Boutroux. Paris: Librairie Générale Française, 1991.

Novos Ensaios sobre o Entendimento Humano. São Paulo: Abril Cultural, 1979.

Réfutation inédite de Spnoza. Leitura e cópia de manuscrito e tradução por Martine de Gaudemar. Arles: Actes Sud, 1999.

MACHEREY, P. Hegel ou Spinoza. Paris: La Découverte, 1990.

MARQUES, S. T. Ser, tempo e liberdade: as dimensões da ação livre na filosofia de Henri 
Bergson. São Paulo: Associação Editorial Humanitas: Fapesp, 2006.

MATHERON, A. Individu et communauté chez Spinoza. Paris: Minuit, 1969.

MERLEAU-PONTY, M. L'union de l'âme et du corps chez Malebranche, Biran et Bergson. Paris: Vrin, 2002. Signes. Paris: Gallimard, 2003.

Phénoménologie de la Perception. Paris: Gallimard, 1945. Edição Brasileira: Fenomenologia da Percepcão. São Paulo: Martins Fontes.

L'Oeil et l'Esprit. Paris: Gallimard, 1964.

Sens et Non-Sens. Paris: Nagel, 1966.

Visible et l'invisible. Paris: Gallimard: 1964; Edição Brasileira: O Visível e

o Invisível. Trad. de J. A. Gianotti e A. M. de Oliveira. São Paulo: Perspectiva, 2000.

MOREAU, P.-F. Spinoza: l'expérience et l'éternité. Paris: PUF, 1994.

MORFINO, V. (org.) La Spinoza-Renaissance nella Germania di fine Settecento. Milano: Edizioni Unicopli, 1998.

Incursioni spinoziste. Causa, tempo, relazione. Milano: Mimesis, 2002.

“Sotto strati di notte. Il 'caso’ Spinoza nella Germania della prima metà dell'Ottocento”, em Battistel, G., Del Lucchese, F., Morfino (curadores), L'abisso dell'unica sostanza. L'immagine di Spinoza nella prima metà dell'Ottocento tedesco, Macerata, Quodlibet, no prelo).

Substantia sive organismus. Immagine e funzione teorica di Spinoza negli scritti jenese di Hegel. Milano: Guerini e Associati, 1997.

MOUTSOPOULOS, E. La critique du platonisme chez Bergson. Atenas: ?ditions Grigoris, 1980.

NEWTON, I. Princípios Matemáticos. Tradução de Pablo Mariconda e Luiz H. Lopes dos Santos. São Paulo: Abril Cultural, 1979.

PINTO, D. C. M. Espaço, percepção e inteligência: Bergson e a formação da consciência empírica humana. Dissertação de Mestrado defendida no Departamento de Filosofia da Faculdade de Filosofia, Letras e Ciências Humanas, em 1994.

Consciência e corpo como memória: subjetividade, atenção e vida à luz da filosofia da duração. Tese de doutorado apresentada ao Departamento de Filosofia da Faculdade de Filosofia, Letras e Ciências Humanas, em 2000.

PLATAO. A República. Lisboa: Fundação Calouste Gulbenkian, 1993. Diálogos. São Paulo: Nova Cultural, 1996.

POLITZER, G. La fin d'une parade philosophique: le Bergsonisme. Paris: Les Revues, 1929. 
POLIN, R. "Y a-t-il chez Bergson une philosophie de l'Histoire?” in Les études bergsoniennes, t. IV. Paris: PUF, 1956.

PRADO, B. F. Jr. Presença e Campo Transcendental: Consciência e Negatividade na Filosofia de Bergson. São Paulo: Edusp, 1989.

ROUSSET, B. L’immance et le salut, regards spinozistes. Paris: Kimé, 2000.

La perspective finale de L'Ethique et le problème de la cohérence du spinozisme. Paris, J.Vrin, 1968.

SANTO AGOSTINHO. Confissões. São Paulo: Paulus, 2004.

SANTIAGO, H. Espinosa e o cartesianismo: o estabelecimento da ordem nos princípios da filosofia cartesiana. São Paulo: Humanitas: FAPESP, 2000.

SARTRE, J.-P. L'être et le Néant. Paris: Gallimard, 1982. L’imagination. Paris: PUF, 1965.

SILVA, F. L. Bergson: intuição e discurso filosófico. São Paulo: Loyola, 1994.

Ciência e consciência: o lugar da psicologia no pensamento de Bergson.

Dissertação de Mestrado defendida no Departamento de Filosofia da Faculdade de Filosofia, Letras e Ciências Humanas, em 1975.

“Apresentação ao artigo de Max Horkheimer” in Cadernos de Filosofia Alemã 6. “Constituição das exigências lógicas: Bergson leitor de Aristóteles” in Discurso. São Paulo, $n^{0} 18$, p. 143-60, 1990.

“Pragmatismo e humanismo: Bergson, leitor de William James” in Cognitio. São Paulo, nº 2, p. 193-202, 2001.

“Bergson, Proust: tensões do tempo" in NOVAES, A. (org.). Tempo e presença. São Paulo: Cia das Letras, 1992.

"Descontrole do tempo histórico e banalização da experiência” in Mutações: ensaios sobre as novas configurações do mundo. Rio de Janeiro: Agir; São Paulo: Edições SESC SP, 2008.

TATIAN, D. (org.) Spinoza Tercer Coloquio. Córdoba: Brujas, 2007. (org.) Spinoza Quinto Coloquio. Córdoba: Brujas, 2009. Spinoza, una introducción. Buenos Aires: Quadrata, 2009.

THEAU, J. La Critique Bergsonienne du Concept. Paris: PUF, 1968.

THIBAUDET, A. Le Bergsonisme. Paris: NRF, 1924.

TROTIGNON, P. L’Idée de vie chez Bergson et la critique de la méthaphisique. Paris: PUF, 1968. 
“Bergson et Spinoza” in Spinoza au Xxe siècle. Paris: PUF, 1990.

WOOLHOUSE, R. S. Descartes, Spinoza, Leibniz: the concept of substance in seventeenchcentury metapyisics. London; New York: Routledge, 1993.

WORMS, F. (org.) Annales bergsoniennes II. Bergson, Deleuze, la phénoménologie. Paris: PUF, 2004.

WORMS, F. Le vocabulaire de Henri Bergson. Paris: Ellipses, 2000.

“Les trois dimensions de la question de l'espace dans l'oeuvre de Bergson” in Epokhé, n ${ }^{\circ}$, Grenoble, J. Millon, 1994.

ZAC, S. Spinoza en Allemagne: Mendelssohn, Lessing et Jacobi. Paris: Méridiens Klincksieck, 1989.

“Les thèmes spnozistes dans la philosophie de Bergson” in Les études bergsoniennes, t.

VIII. Paris: PUF, 1968. 
Apêndice: Contra e pelo paralelismo: Deleuze, leitor bergsoniano de Espinosa?

Contra o paralelismo

Bergson, mesmo não tendo cunhado o termo ou a interpretação, foi responsável, em parte considerável, pela leitura paralelista que se fez da filosofia de Espinosa, no século XX. Dois dentre os mais reconhecidos intérpretes de Espinosa, que também influenciaram muitos dos estudiosos atuais, usaram o termo para se referir à filosofia espinosana: Martial Guéroult e Gilles Deleuze. Mas, será que o fizeram na direção da crítica bergsoniana? Ou ainda, será que em ambos trata-se do mesmo “paralelismo”? Apontaremos apenas algumas questões sobre a leitura de Guéroult, pois o que nos interessa aqui é entender o sentido do "paralelismo” afirmado por Deleuze, ou seja, interrogar por que ele conviria mais a Espinosa do que a Leibniz, por quem fora afirmado.

Martial Guéroult, como demonstra Éricka Marie Itokazu ${ }^{276}$, toma os “ideados” expostos por Espinosa como “coisas” tanto no que se refere às coisas propriamente ditas (modos da extensão) quanto no que se refere às próprias idéias, visto que estas podem ser objetos de outras idéias, como acontece com as idéias reflexivas, que têm outras idéias como ideados. O paralelismo não se reduziria a uma correspondência entre os modos da Extensão e do Pensamento, abrangendo também a ordem e conexão dos modos de todos os outros atributos em relação com o Pensamento e, ainda, estando presente no interior deste atributo, quer dizer, haveria correspondência entre a ordem e conexão das idéias, como ideados, e das idéias das idéias. Em todos os casos, os modos do Pensamento é que fazem convergir a correspondência, de maneira que a relação se faz a partir da cognição, tendo por centro o atributo Pensamento. Assim, ele lê o paralelismo sob dois pontos de vista, como extra-cognitivo e intra-cognitivo, sendo este tomado, por sua vez, sob duas formas distintas. O primeiro aspecto do paralelismo intra-cognitivo refere-se à “idéia considerada como essência formal", enquanto o segundo aspecto toma a "idéia considerada em sua forma ou natureza, 'a idéia da idéia não sendo nada outro que a forma da idéia",277. Donde, conclui Itokazu que Guéroult acaba por colocar o atributo pensamento em evidência, em relação aos demais, ao mesmo tempo em que retira sua potência infinita, por condicioná-lo à correspondência extra-cognitiva.

\footnotetext{
${ }^{276}$ ITOKAZU, E. M. Tempo, duração e eternidade na filosofia de Espinosa. Tese de doutorado defendida na Faculdade de Filosofia, Letras e Ciências Humanas da Universidade de São Paulo, em 2008. Seguiremos a sua exposição sobre o paralelismo interpretado por Guéroult, pois ela aponta os problemas que também vemos "nele”. Quanto a Deleuze, pensamos que não pode ser posto ao lado de Guéroult no que tange a essa questão, como tentaremos mostrar neste texto, pela releitura do “interpretação” deleuzeana.

${ }^{277}$ Ibidem, p. 58.
} 
Afirmar um paralelismo seria, portanto, negar autonomia aos atributos e tornar ainda mais incompreensível a união entre corpo e alma, cavando entre ambos uma intransponível separação. Nas suas palavras,

E tal é a adesão ao paralelismo, tão comumente aceito, que é o mesmo comentador, que tanto defendera a autonomia do conhecimento para o domínio da matéria, exaltara a extinção de suas qualidades ocultas e comemorara a liberação do corpo humano de uma mente que o governasse, toda esta autonomia galgada nos avanços do mecanicismo seiscentista, meritório do "progresso do conhecimento do corpo humano", ainda que pago "pelo recuo do conhecimento do corpo humano"... precisamente este mesmo comentador afirma : "Espinosa proíbe pensar uma tal união [corpo e mente], ou mesmo uma tal interação: eis porque o termo paralelismo convém tão bem à sua filosofia, ainda que não faça parte de seu vocabulário”. Que o paralelismo nos auxiliasse a imaginar que nem a mente pode determinar um corpo a agir, nem o corpo pode determinar a mente a padecer ou pensar, porém, nós agora perguntamos, a que custo? Linhas que correm paralelamente e que somente se encontrariam num hipotético ponto localizado no infinito (em Deus, substância absolutamente infinita), contudo, para nós, modos finitos desta Substância única, parecem construir uma imagem clandestina: a de que corpo e mente seriam duas coisas quase absolutamente separadas (os atributos são infinitos em seu gênero, autônomos e indenpendentes), tal a impossível interação, tal a incompreensível união. Uma vez apartados, nosso corpo e nossa mente parecem ter de carregar consigo o fardo de jamais poderem se reencontrar ${ }^{278}$.

Afirmar um paralelismo rigoroso é, concordamos com Itokazu, colocar mais a separação do que a união ou forjá-la por meio de uma ligação entre pontos paralelos correspondentes. Tal era, sob um de seus aspectos, o sentido da crítica bergsoniana, como vimos no primeiro capítulo. Descartes teria tido o mérito de postular uma ação recíproca entre corpo e mente, de modo a não impossibilitar a comunicação entre ambos. Mas, com Espinosa, sobretudo, ela teria se perdido no rigor da doutrina e em sua matematização. Por isso consideramos que uma interpretação da filosofia de Espinosa como paralelista incorre nos problemas ora apontados. Como ficaria, então, a afirmação de Deleuze segundo a qual o termo "paralelismo" conviria ao mais sistema espinosano do que ao leibniziano? Levantamos a questão sobre o uso do termo "paralelismo” por Deleuze porque nos custava acreditar que um autor tão íntimo do pensamento bergsoniano pudesse ter afirmado um mesmo paralelismo ao escrever uma obra relevante e que demonstra muito cuidado e admiração no que tange à filosofia de Espinosa. Afirmaria ele outro paralelismo? Ou será que o termo foi utilizado quando, de fato, a 
leitura não é nada paralelista? Para Bergson, a palavra “expressão” deveria ser tomada, na filosofia de Espinosa, em seu sentido matemático. Teria ela também, para o autor de Spinosa et le problème de l'épression, o mesmo sentido?

\title{
Pelo paralelismo
}

Entender a razão de tal declaração contundente, a respeito do paralelismo espinosista, pode ser relevante para recolocar os problemas da interpretação tradicional do paralelismo (a qual confunde, por exemplo, a expressão espinosana com a leibniziana, ou seja, a confunde com um espelhamento entre heterogêneos, ou faz da substância um ponto no qual se fundem os diversos atributos) e mostrar que a afirmação do termo (paralelismo) em Deleuze não significa reafirmação da tradição interpretativa, nem deslize terminológico ou conceitual. O que seria então? Não vamos responder ponto por ponto às críticas de Bergson. Elas foram nosso ponto de partida para o questionamento do paralelismo afirmado por Deleuze, fazendo-nos supor que, se o "paralelismo" declarado por este último não se associasse à interpretação tradicional da filosofia de Espinosa, então, talvez, mesmo afirmando o termo, ele pudesse nos ajudar a entender melhor o tema, desvecilhando o pensamento espinosano dessa rede interpretativa e, quem sabe, fornecendo subsídios para interrogá-la ou refutá-la.

Para Deleuze, Espinosa escreveu, sobretudo, uma filosofia prática. Em Spinoza, philosophie pratique, o autor declara que conhecemos sob o nome de paralelismo uma das teses mais célebres de Espinosa, a qual consiste em negar toda relação de causalidade entre o espírito e o corpo, bem como interdita toda eminência de um sobre o outro, não havendo superioridade da alma sobre o corpo ou do corpo sobre a alma. Assim, lemos que

\begin{abstract}
A significação prática do paralelismo aparece na inversão do prinípio tradicional sobre o qual a Moral era fundada como empreendimento de dominação das paixões pela consciência: quando o corpo agia, a alma padecia, e a alma não agia sem que o corpo padecesse (regra da relação inversa, cf. Descartes, Tratado das paixões, artigos 1 e 2). De acordo com a Ética, ao contrário, o que é ação na alma é também, necessariamente, ação no corpo, o que é paixão no corpo é também, necessariamente, paixão na alma. Nenhuma eminência de uma série sobre a outra ${ }^{279}$.
\end{abstract}

Mesmo discorrendo sobre "séries” e “paralelismo”, a ênfase deleuziana, aqui, se volta

\footnotetext{
${ }^{278}$ Ibidem, p. 62.

${ }^{279}$ Deleuze, G. Spinoza, philosophie pratique, p. 28.
} 
para as potências do corpo e do espírito e para a igualdade de princípio entre as séries. Ele mantém a autonomia dos atributos, o que é fundamental, uma vez que cada um deve ser concebido por $\mathrm{si}^{280}$, e interpreta a identidade de conexão como uma isonomia, afastando qualquer interpretação ou oposição fundada na moral tradicional, para a qual um corpo fraco significava uma alma forte, e vice-versa. A conexão não é linear, e pode ser pensada como potência produtiva. Em nenhum momento é utilizada a imagem de séries como linhas que se encontrariam no infinito.

Nesse livro ainda, Deleuze menciona três paralelismos como três identidades, quais sejam: “identidade de ordem” entre corpos e espíritos ou fenômenos do corpo e fenômenos do espírito, o que o autor entende como uma isomorfia, ou seja, uma igualdade de forma; "identidade de conexão" entre as duas séries, e aqui se trata de uma isonomia ou equivalência, uma igualdade de princípio ou dignidade; e, por fim, “identidade de ser”, uma vez que a mesma modificação é produzida no atributo pensamento, sob o modo de um espírito, e no atributo extensão, sob o modo de um corpo. A explicação mais detalhada do paralelismo ou dos paralelismos pode ser obtida na segunda parte de Spinoza et le problème de l'expression, a saber, "Le parallélisme et l'immance”, mais especificamente ainda nos capítulos sexto e sétimo. Centraremos nossa leitura no capítulo sexto, "L'expression dans le parallélisme”, pois nele podemos já encontrar os termos para uma comparação/confrontação com a leitura bergsoniana e tradicional.

Antes de mais nada, faz-se necessário uma apresentação sobre o que Deleuze entende por “expressão” em Espinosa, centro de seu interesse e apreço pelo filósofo.

Segundo Deleuze, a “expressão é, em Deus, a própria vida de Deus”. Deus não produz o mundo, o universo ou a natureza naturada para se expressar (finalismo). Ele se expressa em si mesmo, na sua própria natureza, nos atributos que o constituem. Mas, se Deus se expressa nos atributos que constituem a natureza naturante, estes, por sua vez, se expressam nos modos, que constituem a natureza naturada. A questão que se colocaria, então, seria por que o segundo nível ou a produção de um universo modal ${ }^{281}$. Para responder a ela, Deleuze lança mão de dois argumentos, quais sejam: Deus age ou produz como se compreende (compreendendo-se necessariamente, age

\footnotetext{
${ }^{280}$ Etica, demon.IIP6: “Cada atributo é concebido por si, sem outro (pela proposição 10 da Parte I). Portanto, os modos de cada atributo envolvem o coneito de seu atributo, e não o de outro; por isso (pelo ax. 4 da Parte I) têm como causa Deus enquanto considerado apenas sob aquele atributo de que são modos” (Tradução do Grupo de Estudos Espinosanos da Universidade de São Paulo).

${ }^{281}$ Deleuze, G. Spinoza et le problème de l'expression, p. 88. Na introdução do livro, Deleuze faz uma distinção entre dois níveis de expressão. No primeiro, a substância se exprime em seus atributos e cada atributo exprime uma essência. No segundo, os atributos se expressam nos modos, que deles dependem, e cada modo expressa uma modificação (o que Deleuze chama de um "segundo nível de expressão” ou "expressão da expressão”). O “primeiro nível deve ser compreendido como uma verdadeira constituição, quase uma genealogia da essência da substância. O segundo deve ser compreendido como uma verdadeira produção das coisas” (cf. op. cit., p. 10).
} 
necessariamente) e Deus produz como existe (existindo necessariamente, produz necessariamente). Ora, compreender é o oposto de conceber algo como possível: compreender é deduzir propriedades a partir do que se apreende como necessário. Nesse argumento, os modos são assimilados a propriedades logicamente necessárias que seguem da essência de Deus tal como ela é compreendida $^{282}$. E, desse ponto de vista, a expressão desenvolve um papel determinante. "Deus não se expressa sem se compreender enquanto se expressa. Deus não se expressa formalmente em seus atributos sem se compreender objetivamente em uma idéia. A essência de Deus não é expressa nos atributos como essência formal, sem ser expressa em uma idéia como essência objetiva” ${ }^{\text {,283 }}$. Os atributos não expressam a essência da substância sem se relacionarem com um entendimento que os compreende objetivamente, ou seja, que perceba o que eles expressam. A palavra "perceber" indica que o entendimento não capta nada que não esteja na natureza. No segundo argumento, "Deus produz como existe”, os modos não são mais assimilados a propriedades lógicas, mas a afecções físicas preferencialmente. Trata-se de um argumento, segundo Deleuze, fundado sobre a potência, uma vez que, quanto mais potência há uma coisa, mais ela pode ser afetada por um maior número de modos. Deus tem uma potência infinita de existir e, portanto, tem um poder de ser afetado de uma infinidade de maneiras, que corresponde à sua potência. Esse poder é completamente preenchido, não por afecções que venham de algo que não seja ele mesmo, o qual produz necessária e ativamente uma infinidade de coisas que o afetam de uma infinidade de modos. Deus age como se compreende e como existe: em seus atributos, que exprimem, ao mesmo tempo, sua essência e sua existência. As coisas produzidas não existem fora dos atributos, os quais são condições sob as quais Deus existe e age. Assim, os "atributos são formas unívocas e comuns: eles se dizem, sob a mesma forma, das criaturas e do criador, dos produtos e do produtor, constituindo formalmente a essência de um, contendo formalmente a essência dos outros»"284. O que significa, para Deleuze, que o princípio da necessidade da produção reenvia a uma dupla univocidade: univocidade da causa (Deus é causa de

\footnotetext{
282 Segundo Deleuze, Espinosa chega a apresentar essa proposição como um axioma que reenvia a concepções aristotélicas. Deus se pensa a si mesmo, ele é objeto de seu pensamento e sua ciência não tem outro objeto que ele mesmo. Esse princípio é o que se opõe à idéia de um entendimento divino que pensaria “possíveis” (Deleuze, G. Spinoza et le problème de l'expression, p. 89). Muitos comentadores de Aristóteles poderiam reunir argumentos convincentes para mostrar que Deus, pensando a si mesmo, pensa também todas as outras coisas que dele decorrem necessariamente (assim como os Hebreus, que Espinosa felicita, e que são filósofos judeus aristotélicos, viram que Deus, o entendimento de Deus e as coisas nele compreendidas eram uma única e mesma coisa). "Todavia, a teoria espinosista da idéia de Deus é muito original para se fundar num simples axioma ou se reclamar de uma tradição" (Ibidem, p. 89). Ou seja, Deleuze nega aquilo que Bergson afirma reiteradamente: não só a "redução" da filosofia espinosana à de Aristóteles, como a sua "filiação” a uma tradição. Espinosa não estaria inscrito numa tradição, cujas teses seriam por ele retomadas ou desenvolvidas. Por isso, é importante entender a originalidade da sua "idéia de Deus”.

${ }^{283}$ Deleuze, G. Spinoza et le problème de l'expression, p. 89.

${ }^{284}$ Ibidem, p. 90.
} 
todas as coisas no mesmo sentido em que é causa de si) e univocidade dos atributos (Deus produz por e nos mesmos atributos que constituem sua essência). Assim, Espinosa não cessará de mostrar o erro que consiste em atribuir a Deus atributos humanos, tais como entendimento e vontade. A imagem de um Deus essencialmente dotado de entendimento e vontade é construída por analogia com os atributos humanos. Tal analogia parte de uma equivocidade (o entendimento e a vontade divinos teriam com os humanos apenas uma “comunidade de nomes”) e chega a uma eminência (o entendimento e a vontade divinos seriam incomparáveis aos humanos). Deus não produz por que quer, ou seja, devido à sua vontade, mas porque ele é. Ele não produz porque concebe as coisas como possíveis, ou seja, devido ao seu entendimento, mas porque compreende a si mesmo, compreende sua própria natureza.

A ordem na qual Deus produz necessariamente é a da expressão dos atributos: primeiramente, cada atributo se exprime em sua natureza absoluta, ou seja, um modo infinito imediato é a primeira expressão de um atributo. Depois, o atributo modificado se exprime em um modo infinito mediato. Enfim, o atributo se exprime "de um modo certo e determinado", ou melhor, de uma infinidade de maneiras que constituem os modos existentes finitos. "Esse último nível permaneceria inexplicável se os modos infinitos, no gênero de cada atributo, não contivessem as leis ou os princípios de leis pelos quais os modos finitos correspondentes são eles mesmos determinados e ordenados”285. A primeira fórmula (aspecto) do paralelismo diz respeito à ordem e esta não é senão a ordem na qual Deus produz necessariamente, o que significa uma ordem expressiva dos atributos: “Os atributos se expressam, portanto, em uma única e mesma ordem: até os modos finitos, que devem ter a mesma ordem nos diversos atributos. Essa identidade de ordem define uma correspondência de modos: a todo modo de um atributo corresponde necessariamente um modo de cada um dos outros atributos”286 . Logo, se existe uma ordem de produção, ela é a mesma para todos os atributos. A identidade de ordem ou correspondência entre modos de atributos diferentes exclui toda relação de causalidade real entre os modos ou entre os atributos. Os modos envolvem exclusivamente o conceito de seu atributo, não o de qualquer outro. A expressão dos atributos se refere à mesma ordem expressiva e não a uma expressão como espelhamento de atributos distintos e heterogêneos - os modos não se expressam uns aos outros e a correspondência se refere ao encadeamento necessário dos diferentes modos com a mesma ordem nos diversos atributos. Por correspondência, Deleuze entende o que se passa com duas coisas que, por serem partes de um todo, nada pode mudar em uma que não tenha seu correspondente na outra, e nenhuma pode mudar sem

${ }^{285}$ Ibidem, p. 93. 
que o próprio todo mude ${ }^{287}$. É isto que define, de acordo com Deleuze, a primeira fórmula do paralelismo de Espinosa: uma identidade de ordem ou correspondência entre modos de atributos diferentes. Quanto ao que podemos chamar de “paralelas”, Deleuze afirma que são: “duas coisas ou duas séries de coisas que estão em uma relação constante, tal que não haja nada em uma que não tenha um correspondente na outra, toda causalidade real entre as duas sendo excluída”. O que é evidenciado com essa primeira fórmula do paralelismo e com a definição de “paralelas” é (de trás pra frente): primeiramente, a exclusão da causalidade real entre os atributos e modos de atributos diferentes; depois, a correspondência ou mudança concomitante e conjunta nas coisas que são partes de um mesmo todo (não se trata de uma correspondência ponto por ponto entre as coisas no sentido de tomá-las como estáticas, mas de uma correspondência de mudança, porque nada muda em uma sem que algo mude na outra, o que significa uma correspondência dinâmica - os atributos são formas dinâmicas e ativas); finalmente, a relação constante entre tais coisas correspondentes, ou seja, não se trata de tomar as coisas ou séries separadamente, mas de dar ênfase à relação que há entre elas.

Em seguida, Deleuze questiona se a palavra “paralelismo” conviria ao sistema espinosano, uma vez que fora criada por Leibniz e utilizada por sua conta para designar a correspondência entre séries autônomas e independentes. Isto leva o nosso comentador a pensar que a identidade de ordem não é suficiente para distinguir o sistema espinosano: ela se encontraria mais ou menos em todas as doutrinas que se recusam a interpretar a relação em termos de causalidade real. Deleuze afirma então que, “se a palavra paralelismo designa adequadamente a filosofia de Espinosa é porque ela implica outra coisa que uma simples identidade de ordem, outra coisa que uma correspondência"288. Espinosa não se contentaria, assim, no seu entender, com a identidade e a correspondência para definir a união dos modos, a ligação que os une, o que quer dizer que a correspondência é insuficiente para definir a relação entre os modos de atributos distintos. Por isso, haveria ainda duas outras fórmulas do paralelismo, que prolongam a primeira (a identidade de ordem ou correspondência entre modos de atributos diferentes), quais sejam: identidade de conexão ou igualdade de princípio, identidade de ser ou unidade ontológica. Tal teoria é expressa no escólio de II, P7: "Uma única ordem, ou seja, uma única e mesma conexão de causas, dito de outro modo, as mesmas coisas se seguindo umas das outras”. De acordo com a leitura deleuzeana, a firmação de uma identidade de ser expressa algo a mais que a identidade de conexão, e esta implica algo a mais

\footnotetext{
${ }^{286}$ Ibidem, p. 93.

${ }^{287}$ Ibidem, p. 94.

${ }^{288}$ Ibidem, p. 95; grifo nosso.
} 
que a correspondência. “Com efeito, a identidade de conexão não significa apenas uma autonomia das séries correspondentes, mas uma isonomia, ou seja, uma igualdade de princípio entre séries autônomas ou independentes”289. Se supusermos duas séries cujos princípios são desiguais, o princípio de uma seria eminente em relação ao da outra, assim como acontece entre "um sólido e sua projeção, entre uma linha e sua assíntota”, nos quais “há identidade de ordem ou correspondência, e não há, propriamente falando, 'identidade de conexão"’290. Tanto num como noutro exemplo - o sólido e sua projeção, a linha e sua assíntota - somos remetidos às críticas de Bergson ao paralelismo, espinosismo e seus desdobramentos. Mas, o que se passa aqui é que eles estão sendo usados como exemplos de correspondência, e não de paralelismo. Ora, Bergson critica justamente o fato de que, com a correspondência entre as séries, uma delas é tomada como modelo para a outra, como ocorre com “um sólido e sua projeção”, e é isto que está em jogo nas suas críticas à psicofísica, uma vez que o mental acaba por ser reduzido ao cerebral (epifenomenismo).

A identidade de conexão garante uma isonomia porque as "paralelas, em sentido preciso”, exigem uma igualdade de princípio entre as séries correspondentes. "É a igualdade dos atributos que dá ao paralelismo seu sentido estrito, garantindo que a conexão é a mesma entre coisas cuja ordem é a mesma”291. Por isso, segundo Deleuze, Leibniz cria a palavra "paralelismo”, mas a invoca de maneira muito geral e pouco adequada, usando-a para “a correspondência entre séries autônomas, substâncias e fenômenos, sólidos e projeções”, cujos princípios são singularmente desiguais. Quando “fala mais precisamente”, Leibniz “invoca a imagem da projeção preferencialmente à das paralelas”. A crítica ao paralelismo, tal como feita por Bergson, seria mais acertadamente, do ponto de vista dessa interpretação, uma crítica ao sistema leibniziano da "projeção" e não ao "verdadeiro paralelismo”, o espinosano. Ora, “Espinosa não emprega a palavra 'paralelismo', mas ela convém a seu sistema, porque ele põe a igualdade dos princípios de que decorrem as séries independentes e correspondentes” ${ }^{\prime 292}$. O paralelismo de Espinosa se ligaria, assim, às suas “intenções polêmicas” tais como a recusa da eminência, hierarquia ou superioridade de uma série sobre outra, seja da série espiritual sobre a física (problemática metafísica de sua época), seja da física sobre a psíquica (questão científica e metafísica da época de Bergson, advinda do mecanicismo moderno).

Quanto à terceira fórmula do paralelismo, a que afirma a identidade do ser, ela irá, de acordo com Deleuze, ainda mais longe, pois “os modos de atributos diferentes não têm apenas a mesma ordem e a mesma conexão, mas o mesmo ser; são as mesmas coisas que se distinguem apenas pelo

\footnotetext{
${ }^{289}$ Ibidem, p. 95.

${ }^{290}$ Ibidem, p. 95-6.

${ }^{291}$ Ibidem, p. 96.
} 
atributo do qual elas envolvem o conceito. Os modos de atributos diferentes são uma única e mesma modificação que difere somente pelo atributo” ${ }^{293}$. Com essa identidade de ser ou unidade ontológica, Espinosa recusaria a intervenção de um Deus transcendental, que colocaria um acordo entre cada termo de uma série com um termo de outra - acordo entre as séries em função de seus princípios desiguais. Ou seja, a terceira fórmula também é explicada por Deleuze de modo a contrapor a filosofia de Espinosa a qualquer doutrina paralelista que, para negar a causalidade, afirme a correspondência, estabelecendo uma desigualdade de princípios ou uma intervenção externa. O paralelismo "estritamente falando" - como o entende Deleuze - "não pode ser compreendido nem do ponto de vista de uma causa ocasional, nem do ponto de vista de uma causalidade ideal, mas somente do ponto de vista de um Deus imanente e de uma causalidade imanente”294. Deus não tem o papel de equilibrar o sensível e o mental, intervindo ocasionalmente no mundo (ocasionalismo de Malebranche), nem o de harmonizar os pontos de vista das partes que formam o todo, numa criação primeira que torna desnecessário o apelo à intervenção futura (harmonia preestabelecida de Leibniz). Com a "última fórmula do paralelismo", implicando a imanência, Deleuze contrapõe a doutrina espinosana às dos outros sucessores de Descartes que, para Bergson, teriam em comum a solução paralelista ao problema da união substancial, Leibniz e Malebranche, e seriam, por isso, a origem dos problemas metafísicos e científicos posteriores. Para Deleuze, o que está em jogo em tudo isso é a essência da expressão. O modelo expressivo de Leibniz é o da assíntota ou da projeção, e “o de Espinosa é o 'paralelista",295, que “implica igualdade entre duas coisas que exprimem uma terceira, e

\footnotetext{
${ }^{292}$ Ibidem, p. 96.

${ }^{293}$ Ibidem, p. 96.

${ }^{294}$ Ibidem, p. 97.

295 De acordo com Deleuze, a expressão em Espinosa é, de uma parte, uma explicação: desenvolvimento do que se exprime, manifestação do Um no múltiplo (manifestação da substância em seus atributos e, depois, dos atributos em seus modos). De outra parte, a expressão múltipla envolve o Um (nesse caso, a expressão é um envolvimento/implicação). Regra geral que encontramos em seu livro: “a expressão envolve, implica o que ela expressa, ao mesmo tempo em que ela o explica e o desenvolve” (Deleuze, G. Spinoza et le problème de l'expression, p. 12). Todos esses conceitos, justamente porque não se opõem, enviam a um princípio sintético: a complicatio. Deleuze considera que Espinosa e Leibniz, de modo independente um do outro, parecem contar com a idéia de expressão para ultrapassar as dificuldades do cartesianismo, restaurar uma filosofia da Natureza, assim como integrar as aquisições de Descartes em sistemas hostis à visão cartesiana do mundo. Em geral, no que se refere à filosofia de Espinosa, a "expressão" acaba sendo tomada, pelos comentadores, em dois sentidos, cujas interpretações revelam contrasensos em relação a essa filosofia: às vezes, é interpretada como sinônimo de um termo "mais profundo", qual seja, "emanação" (Leibniz já o sugerira, reprovando Espinosa por ter interpretado a expressão em um sentido conforme a Cabala e por tê-la reduzido a uma espécie de emanação); e, às vezes, como sinônimo de "explicação" (para os pós-kantianos, a expressão espinosista é intelectual e abstrata, e os atributos parecem atribuídos à substância por um entendimento ele mesmo explicativo). O contrasenso dessa interpretação está em tomar "explicação" como algo que designa a operação de um entendimento que permanece exterior à coisa, quando se trata de algo que designa, inicialmente, o desenvolvimento da coisa em si mesma e na vida (Ibidem, p. 14). Deleuze identifica Vida e expressividade, que, por sua vez, é identificada à natureza de Deus. Para ele, a melhor palavra para se referir à filosofia de Espinosa é "Vida", o que nos faz pensar (juntamente com outros pequenos indícios, que não caberia
} 
identidade entre essa terceira tal qual é expressa nas outras duas”296. A idéia de expressão em Espinosa invoca, ao mesmo tempo, os três aspectos do paralelismo. Igualdade entre modos distintos (numericamente distintos), que constituem atributos distintos (realmente distintos e não numericamente distintos), e que expressam uma única e mesma coisa. Identidade entre essa coisa e suas expressões. A última fórmula do paralelismo é, portanto, fundamental e primeira, uma vez que expressa a unidade que é causalidade imanente e produtiva de uma infinidade de modos, os quais “não são mais assimilados a propriedades lógicas”. Resumidamente, a identidade de ser (terceira fórmula) garante a igualdade de conexão (segunda fórmula) e a identidade de ordem (primeira fórmula). A correspondência não é suficiente para definir a relação entre os atributos distintos porque é posterior, ou melhor, é consequência da causalidade infinitamente produtiva da Substância, expressa igualmente em todos os atributos na mesma ordem (não se trata de um princípio explicativo, mas ativo e, nesse sentido, dinâmico e produtivo).

O paralelismo, portanto, tal como Deleuze o apresenta, nega a causalidade entre os modos de distintos atributos e entre atributos distintos, nega a eminência de um atributo sobre outro $e$ nega, por fim, a transcencência divina. Isto é extremamente importante porque diferencia Espinosa dos outros paralelistas e, consequentemente, retira dele o peso das nefastas influências que tenham exercido ou que lhes foram imputadas. Por outro lado, o mesmo "paralelismo espinosano" afirma a correspondência como relação constante entre coisas que são partes de um todo, afirma a isonomia ou igualdade de princípio, porque se fundamenta na igualdade dos atributos (mesma potência e essência causal infinita na mesma ordem e conexão), e, por fim, afirma a unidade substancial e sua imanência como unidade diferenciada (pluralidade produtiva). Ele não reitera a leitura tradicional da doutrina espinosista, pelo contrário.

A análise de Deleuze nos mostra que a proprosição II, P7 não se refere apenas à epistemologia, mas à ontologia. Ou seja, ela incide sobre a unidade do conhecimento que não se separa da unidade divina. Passar pelo “paralelismo epistemológico” para chegar no “ontológico” é, aqui, mostrar que se, em Deus, a potência de pensar é igual à potência de agir tal se dá porque se trata de uma unidade de potência em Deus que não se separa da sua unidade de essência. Deleuze parte do paralelismo epistemológico porque o texto da proposição coloca a relação ou identidade entre modos, idéias e coisas, primeiramente. Assim, ele não nega que haja “unidade de ser” (última fórmula do paralelismo) no texto da proposição - em sua demonstração e em seu corolário -, mas

apontar aqui), como apontamos no capítulo terceiro desta tese, se a sua leitura não seria, de certo modo, influenciada pela filosofia de Bergson.

${ }^{296}$ Deleuze, G. Spinoza et le problème de l'expression, p. 97. 
entende que isto remete à questão do conhecimento. Quando analisa o escólio, ele mostra que tal não se desvincula da unidade da substância, ao contrário. No corolário, encontramos a unidade de potência enquanto, no escólio, a unidade de essência. Mas, ao fim e ao cabo, a unidade de potência e a unidade de essência remetem à substância única, e é ela, como causalidade primeira infinita e atual, da qual tudo decorre, formal e objetivamente, que possibilita entender as coisas como unidade ou como uma mesma modificação, nas palavras de Deleuze.

Por que falar em paralelismo? Se o sentido do paralelismo fora renovado pelo tratamento dado no livro (nos capítulos a ele dedicados), como pensamos e intentamos explicar acima (mesmo que brevemente), então, ele não se refere a uma simples correspondência, ou a uma eminência, mas sim, prioritariamente, à unidade imanente da substância única. No caso do paralelismo epistemológico, trata-se de uma mesma ordem, conexão entre idéias e coisas que remete à unidade das potências em Deus. É porque a potência de pensar e agir em Deus é a mesma que se pode falar em uma mesma ordem e conexão entre idéias e coisas. No caso do paralelismo ontológico, trata-se de uma mesma ordem e conexão entre modos de distintos e infinitos atributos infinitos que remete à unidade dos atributos de Deus. É porque Deus, como causalidade infinita e atual, produz infinitas coisas em infinitos atributos com a mesma ordem e conexão que elas se correspondem, sem relação causal. No sexto capítulo de Spinoza et le problème de l'expression, fora afirmado que a correspondência não era suficiente para definir o paralelismo e que era preciso algo a mais, em função do qual esse termo caberia melhor a Espinosa. A correspondência é algo a que se chega $a o$ fim, é efeito e tem como premissa necessária a causalidade infinita imanente de Deus. A causalidade eficiente imanente tem aqui um papel fundamental na dissociação dos paralelismos, ou melhor, na nova compreensão de paralelismo: correspondência apenas signica projeção, eminência e transcencência, enquanto paralelismo significa correspondência porque significa, primordialmente, igualdade e imanência. O termo “igualdade” não seria suficiente para defini-lo, como na interpretação de Chantal Jaquet - ao julgar que Deleuze o eclipsou pelo uso do "paralelismo”, como veremos a seguir. O termo “paralelismo”, controverso, é usado porque permite ir além da igualdade e da correspondência, até a imanência (unidade diferenciada), explicitando a originalidade de Espinosa, não no sentido afirmado por Bergson ou pela tradição.

A questão estaria mais especificamente no uso do termo, o qual não nos remete apenas à tradição interpretativa, mas também evoca (por si mesmo) a imagem em que ela se acosta: a de linhas paralelas constituídas por “pontos” ou “paradas” correspondentes (numa linguagem bergsoniana). Ainda que outro seja o sentido de paralelas, outro seja o sentido de correspondência (consequência da imanência) e outro seja, por fim, o sentido do próprio termo “paralelismo”, o uso 
do termo é algo complicado e mesmo dificilmente explicável. Teria sido empregado por já estar consagrado? Tratar-se-ia [seu uso] de um problema menor ou sem relevância porque pautado apenas por uma palavra que estaria lá como que por acaso (ou seja, usou “paralelismo”, mas podia ter usado outro termo qualquer)? Neste caso, contudo, Deleuze teria mantido, ainda que a sua revelia (em detrimento de sua própria leitura), os problemas e equívocos presentes em tantas leituras da filosofia de Espinosa - eclipsando, pelo “paralelismo”, outros termos mais adequados. Esta é a interpretação de Chantal Jaquet, cuja menção ao paralelismo declarado por Deleuze nos pareceu estranha e facilmente resolvida. No livro L'unité du corps et de l'esprit: affects, actions et passions chez Spinoza, em um capítulo especialmente elaborado "Pour finir avec le parallélisme”, Jaquet faz alusão a dois “intérpretes” franceses que mantiveram de maneira equivocada o termo “paralelismo”. De um lado, estaria Martial Guéroult, cuja leitura, apesar de sublinhar que a proposição II, P7 trata mais de uma identidade do que de um paralelismo, retomaria, por sua conta, a fórmula leibniziana, deduzindo, ainda mais, um paralelismo extra-cognitivo e um intra-congnitivo com duas formas ${ }^{297}$. De outro lado, em suas palavras, conviria “voltar às belas análises que Gilles Deleuze, na segunda parte de sua obra Spinioza et le problème de l'expression, consagra à doutrina do paralelismo. A despeito de suas precauções e de sua desconfiança reconhecida em relação à palavra 'paralelismo', Deleuze recorre ainda a essa bengala que o impede, finalmente, de se concentrar na elucidação do conceito fundamental de igualdade, cuja importância, no entanto, ele sublinhou”298. Ora, a “desconfiança”, à qual a autora se refere, aparece no texto de Deleuze como um momento, por assim dizer, retórico de sua exposição, na qual, ele afirma que poderíamos desconfiar “da palavra 'paralelismo', que não é de Espinosa”, para, em seguida, declarar e explicar por que ela conviria mais a ele do que a Leibniz, como mostramos. Ele não demonstra desconfiança ou receio no uso do termo, pelo contrário, o utiliza com conviç̧ão, o que comprova não se tratar em absoluto de uma "bengala” ou coisa que o valha. Se a leitura de Guéroult (pertinente ou não, equivocada ou não) apresenta um problema de interpretação uma vez que, pelo termo e pelo modo como é exposto (infinitas paralelas extra ou intra-congnitivas), forjaria algo não presente no texto do autor ${ }^{299}$, tal não poderia ser visto

\footnotetext{
297 A esse respeito, conferir o livro de Guéroult, Spinoza, vol. 2, p. 64 e seguintes.

${ }^{298}$ Jaquet, C., L'unité du corps et de l'esprit: affects, actions et passions chez Spinoza, p. 16; grifo nosso.

299 Vale a pena ressaltar que o paralelismo intra-congnitivo, baseado numa espécie de duplicacação da "idéia” na “idéia da idéia” (e da “idéia da idéia” na "idéia da idéia da idéia”, e assim sucessivamente, em infinitas linhas ou paralelas), não parece corresponder de nenhum modo ao texto espinosano, uma vez que, por exemplo, lemos na demonstração de II, P21 que, "na realidade, a idéia da mente, isto é, a idéia da idéia, não é senão a forma da idéia, enquanto esta última é considerada como um modo do pensar, sem relação com o objeto. Com efeito, quando alguém sabe algo, sabe, por isso mesmo, que o sabe, e sabe, ao mesmo tempo, que sabe o que sabe, e assim até o infinito”. Ora, o que segue dessa demonstração, segundo a qual a idéia da idéia é a forma da idéia sem relação com um objeto, mas referida ao saber a respeito do objeto, é afirmação da idéia como certeza reflexiva sobre um saber (consciência da
} 
justamente como um problema porque advindo, digamos, do seu método de leitura, forçando o texto mais que deveria, ainda que com o cuidado de não interpretá-lo? ${ }^{300}$ E quanto a Deleuze? Seu uso não poderia estar, inversamente, circunscrito em um método de leitura? Um método segundo o qual o intérprete só é intérprete porque escolhe, ou porque a escolha realizada o faz assim (a escolha faz o intérprete). A sua interpretação não forçaria o texto e, sim, revelaria (sem dizê-lo explicitamente) o contexto das disputas nas quais Espinosa se inscrevera. Não poderíamos desenvolver o que seria tal método, apenas nos questionamos se isto não se inseriria em uma abordagem que traçaria um plano de leitura pela articulação de determinada filosofia com outras, isto é, pela construção de um dialógo que permitiria confrontá-las e, conforme o caso, diferenciá-las.

Em Pourparlers, numa de suas entrevistas, Deleuze declara o seguinte: “Os filósofos fornecem novos conceitos, eles os expõem, mas não dizem, ou não dizem completamente, os problemas aos quais esses conceitos respondem [...]. A história da filosofia deve, não dizer de novo o que disse um filósofo, mas dizer o que ele subentendia necessariamente, o que ele não dizia e que está, no entanto, presente no que ele disse”. Logo em seguida, ele afirma, numa fórmula bergsoniana, que “a filosofia consiste sempre em inventar conceitos”301, assim como em Spinoza et le problème de l'expression, lemos que “a força de uma filosofia se mede pelos conceitos que ela cria, ou dos quais ela renova o sentido e que impõem um novo recorte às coisas e às ações”302. Em Pourparlers, também é declarado que "Créer n'est pas communiquer, mais résister" ${ }^{303}$ Percebemos ao longo do percurso que expusemos uma preocupação do autor em separar a doutrina espinosana de outras que são confusamente mescladas a ela. O que Deleuze lê como paralelismo espinosano é justamente o

mente sobre um saber) e, por isso, não se trata de uma idéia acrescentada a outra, e sim da mente tomada quando sabe que sabe algo (não é soma ou reprodução estéril ao infinito da mesma "idéia da idéia” ou "saber que sabe”, mas reflexão, a qual não pode ser senão dinâmica, e certeza inabalável). Num artigo intitulado "La tentation du parallélisme: un fantasme géométrique dans l'histoire du spinozisme”, Maxime Rovere afirma que as análises de Guéroult visam a sustentar que o dispositivo ontológico descrito por Espinosa não é um paralelismo, e o que ele [Guéroult] faz é uma advertência que conduziria os leitores ou a repudiarem esse caminho, ou a se valerem dele "de modo a 'resumir' rapidamente, ainda que imperfeitamente, a problemática relação dos atributos”. Tratar-se-ia de crer que poderíamos no limite pensar o sistema da Ética sob o modelo do paralelismo, consituindo o que Rovere chama de uma "tentação" de leitura que acabaria por se impor, apesar da advertência inicial. Ora, pensamos que, neste sentido, é mais pertinente a idéia de "bengala”, que Jaquet, contudo, endereça inconvenientemente a Deleuze, segundo pensamos. Nosso interesse aqui é desfazer essa imagem no que concerne ao texto deleuzeano, não nos atribuindo a tarefa de discutir o que ela significaria em Guéroult, nem de desenvolver a interpretação que este último faz do paralelismo. O artigo de Rovere se encontra em: Jaquet, C.; Sevérac, P.; Suhamy, A.(orgs). La théorie spinoziste des rapports corps/esprit et ses usages actuels. Paris: Hermann Éditeurs, 2009.

${ }^{300}$ A respeito da afirmação de que o "historiador da filosofia não é nunca um intérprete” no método de Guéroult, conferir o texto de Gilles Deleuze “Spinoza et la méthode génerale de M. Guéroult” in L'Ile deserte, p. 203. Nele, lemos também que: “A estrutura não é nunca um não-dito que deveria ser descoberto sob o que é dado, só se pode descobri-la seguindo a ordem explícita do autor”.

${ }^{301}$ Deleuze, G. Pourparlers, p. 186.

302 Ibidem, p. 299.

303 Ibidem, p. 196. 
que o opõe à tradição no que concerne aos conceitos por ele rejeitados (analogia, eminência e transcendência), concernindo o debate em torno de seus “temas polêmicos”. Se o filósofo não forneceu o conceito - paralelismo - estaria ele subentendido no que disse, cabendo ao historiador da filosofia dizê-lo? Mas, neste caso, a questão não seria, a partir de um conceito fornecido pelo filósofo, explicitar os problemas aos quais ele respondia, mas, sim, declarar um termo não fornecido. Pensamos que, ao fazer do paralelismo um conceito que caberia à filosofia de Espinosa, Deleuze explicita os problemas com os quais o filósofo se depara (ligados ao que há de polêmico em sua filosofia) e, ao mesmo tempo, renova o sentido do "paralelismo". Nesse caso, iria o historiador mais longe do que o próprio filósofo? Sim, mas o faria para manter o que "está presente no que ele [Espinosa] disse”. Mais do que simplesmente comunicar a filosofia de Espinosa, Deleuze demonstra a resistência presente nela (aquilo que ela combate) ao mesmo tempo em que se posiciona efetivamente no debate e na polêmica. Melhor dizendo, afirmar o paralelismo, desse modo, e negá-lo a Leibniz, por exemplo, é não só polêmico como um modo de se colocar na discussão a partir de um novo ponto de vista (não se trata, portanto, de um simples uso do termo). Ele não abre mão de usar o termo "paralelismo" porque parece ver nele um operador que permite ir além dos conceitos insuficientes para definir a filosofia espinosana, como o de correspondência. Um operador cuja potência advém de uma torsão nele operada. Uma leitura em que não há acaso, que permite um encontro com os pensamentos do autor e, ainda, pelo que pareceria estranho a ele, possibilita um reencontro, uma metamorfose, subvertendo por dentro a interpretação plasmada e imobilizada. Seria uma subversão, ou seja, uma leitura nova que, ao mesmo tempo, implode a interpretação tradicional, realizando-se como contradiscurso. Não se trata, portanto, de ser simplesmente contra ou pelo paralelismo, e sim de uma leitura a contrapelo. 